\author{
Universidade de São Paulo \\ FaCUldade de Filosofia, Letras e CiênCias Humanas \\ DEPaRTAMENTo de LETRas ClásSiCas e Vernáculas \\ Programa de Pós-Graduação em Literatura Brasileira
}

Dante Pignatari

\title{
Canto da língua: Alberto Nepomuceno e a INVENÇÃO DA CANÇÃO BRASILEIRA
}


FaCUldade de Filosofia, Letras E CiênCias Humanas

DePartamento de letras ClásSiCas e Vernáculas

Programa de Pós-Graduação em Literatura Brasileira

\title{
Canto da língua: Alberto nepomuceno e a INVENÇÃO DA CANÇÃO BRASILEIRA
}

\author{
Dante Pignatari
}

Tese apresentada ao Programa de PósGraduação em Literatura Brasileira do Departamento de Letras Clássicas e Vernáculas da Faculdade de Filosofia, Letras e Ciências Humanas da Universidade de São Paulo, como requisito parcial para obtenção do título de Doutor em Letras.

Orientador: Prof. Dr. José Miguel Wisnik 
São Paulo, de de 200

\section{Canto da Língua: Alberto NePomuceno e a INVENÇÃO DA CANÇÃO BRASILEIRA}

\section{Dante Pignatari}

Esta tese foi submetida ao processo de avaliação pela Banca Examinadora para a obtenção do título de

\section{Doutor em Letras}

E aprovada na sua versão final, em atendendo às normas da legislação vigente da Universidade de São Paulo, Programa de Pós-Graduação em Literatura Brasileira.

Prof. Dr. Cilaine Alves Cunha

Coordenadora do Programa de Pós-Graduação em Literatura Brasileira

Banca Examinadora:

Prof. Dra. Flávia Camargo Toni Prof. Dra. Lia Vera Tomás

Prof. Dr. Marcos Branda Lacerda

Prof. Dr. Lorenzo Mammì

Prof. Dr. José Miguel Wisnik 


\section{AGRADECIMENTOS}

Ao Sérgio Alvim Corrêa, pela generosidade.

Às sopranos Katia Guedes, Cláudia Riccitelli e Patrícia Endo, com quem sigo aprendendo.

Ao Carlos Fernando, que se deixou contagiar por meu entusiasmo com as canções de Nepomuceno e, acompanhado por mim ao piano, as cantou com elegância e verve no espetáculo Canto da Língua, título de sua criação que tomei emprestado para este trabalho.

Ao José Miguel Wisnik, que me acolheu na hora da necessidade, pela confiança.

Ao Carlos Siffert, meu saudoso colega de rádio, pelo incentivo e pelas muitas horas de alegria e música.

Ao Marcos Branda Lacerda, que orientou a primeira etapa de minhas pesquisas e me fez ver a importância da harmonia na constituição da forma e do significado da música.

Ao Claudio Mubarac, que se desviou do caminho para socorrer um amigo aflito.

Ao Paulo Pasta, pela amizade ininterrupta.

À Liana Virdis, Márcia Pastore, Tania Rivitti e Inácio Araujo, pela paciência.

Bruno Pantalena Piazza digitou e editou em Finale, com competência e disposição, todos os exemplos em notação musical.

A formatação da tese de acordo com as normas da ABNT eu devo à querida Maria José Falkemberg Retamal.

Aos meus pais, Lilla e Décio, em contrapartida pelo apoio de toda a vida.

Ao Alexandre Meireles, e à Casa de São Lázaro, pelo alicerce.

E, com devoção, à memória de Alberto Nepomuceno. 
Nenhum poema lírico está completo até ser posto em música. Então, algo único acontece. Só então a inspiração poética é sublimada, ou melhor, fundida no elemento belo e livre da experiência sensorial. Então, pensamos $e$ sentimos ao mesmo tempo e somos, assim, arrebatados."

(Goethe). 
RESUMO

A partir da relação íntima e primordial existente entre palavra e música, este trabalho procura mostrar como o cearense Alberto Nepomuceno (1864-1920), em seu cancioneiro, tenta pela primeira vez, de forma sistemática, criar uma música nacional alinhada à vanguarda de seu tempo.

Palavras-chave: Música Brasileir;, Canção para Voz e Piano; Letra e Música; Nacionalismo; Romantismo. 


\section{ABSTRACT}

Taking as its starting-point the intimate and primordial relationship between words and music, this thesis sets out to show how Alberto Nepomuceno (1864-1920), Brazilian composer from the north-eastern state of Ceará, tried for the first time, in a systematic manner, to create a body of Brazilian music aligned with the vanguard of his time.

Keywords: Brazilian Music; Songs for Voice and Piano; Lyrics and Music; Nationalism; Romanticism. 


\section{LISTA DE EXEMPLOS}

Exemplo 01: F. Schubert. Gretchen am Spinnrade, c. 1-9........................ 20

Exemplo 02: R. Schumann. Mondnacht, Op. 39 no 5, c. 1-13......................................... 21

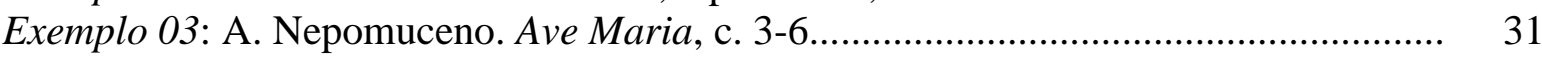

Exemplo 04: A. Nepomuceno. Ave Maria, c. 1-2 ........................................................ 32

Exemplo 05: A. Nepomuceno. Ave Maria, c. 22-26..................................................... 33

Exemplo 06: A. Nepomuceno. Ave Maria, c. 32-36..................................................... 33

Exemplo 07: A. Nepomuceno. Ave Maria, c. 37-40...................................................... 34

Exemplo 08: A. Nepomuceno. Ave Maria, c. 45-51........................................................ 34

Exemplo 09: Anônimo. Coração Santo (transposto para o modo maior).......................... 36

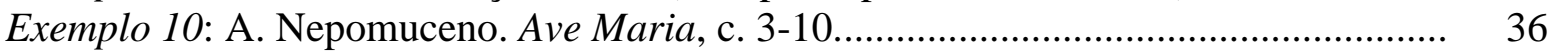

Exemplo 11: A. Nepomuceno. Canção do rio, c. 3-10 ..................................................... 36

Exemplo 12: A. Nepomuceno. Perchè?, c. 1-5.............................................................. 39

Exemplo 13: A. Nepomuceno. Perchè?, c. 6-11......................................................... 40

Exemplo 14: A. Nepomuceno. Perchè?, c. 13-17......................................................... 40

Exemplo 15: A. Nepomuceno. Perchè?, c. 18-23........................................................ 41

Exemplo 16: A. Nepomuceno. Perchè?, c. 23-26...................................................... 41

Exemplo 17: A. Nepomuceno. Perchè?, c. 27-31........................................................ 42

Exemplo 18: A. Nepomuceno. Un Soneto del Dante, c. 1-11 ......................................... 44

Exemplo 19: A. Nepomuceno. Un Soneto del Dante, c. 43-52 ..................................... 45

Exemplo 20: A. Nepomuceno. Serenata di un moro, c. 1-10........................................... 46

Exemplo 21: A. Nepomuceno. Serenata di un moro, c. 10-14........................................... 47

Exemplo 22: A. Nepomuceno. Serenata di un moro, c. 36-41........................................ 47

Exemplo 23: E. Granados. Danzas Españolas: Villanesca, c. 83-90 ............................. 48

Exemplo 24: A. Nepomuceno. Serenata di un moro, c. 12 ............................................ 48

Exemplo 25: A. Nepomuceno. Serenata di un moro, c. 38-39...................................... 49

Exemplo 26: A. Nepomuceno. Der wunde Ritter, c. 1-6............................................ 50

Exemplo 27: A. Nepomuceno. Drömd lycka, c. 1-3................................................... 51

Exemplo 28: A. Nepomuceno. Einklang, c. 1-7....................................................... 53

Exemplo 29: A. Nepomuceno. Einklang, c. 14-16........................................................ 53

Exemplo 30: A. Nepomuceno. Herbst, c. 1-9............................................................... 54

Exemplo 31: R. Wagner. A Valquíria, Ato I, p. 104, c. 2-3............................................ 54

Exemplo 32: A. Nepomuceno. Herbst, c. 28-32 ........................................................ 55

Exemplo 33: A. Nepomuceno. Einklang, c. 22-23 ....................................................... 55

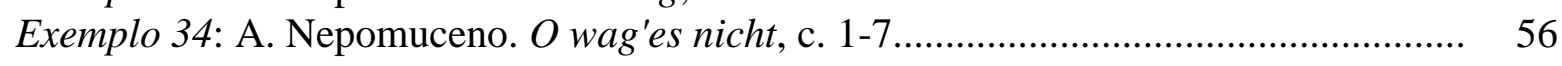

Exemplo 35: A. Nepomuceno. $O$ wag'es nicht, c. 21-26............................................... 56

Exemplo 36: A. Nepomuceno. Wiege sie sanft, o Schlaf, c. 3-6 e c. 54-57 .................... 57

Exemplo 37: A. Nepomuceno. Sehnsucht nach Vergessen, c. 1-14............................... 58

Exemplo 38: F. Schubert. Der Atlas, c. 1-17.............................................................. 59

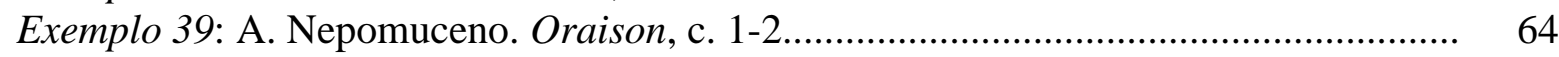

Exemplo 40: A. Nepomuceno. Sehnsucht nach Vergessen, c. 7-9................................ 64

Exemplo 41: A. Nepomuceno. Oraison, c. 1-5............................................................ 64

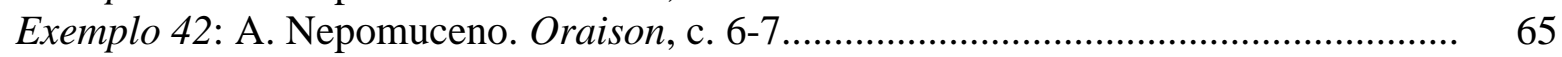

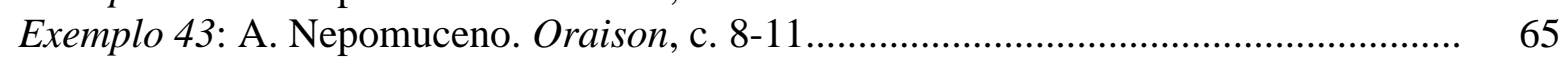

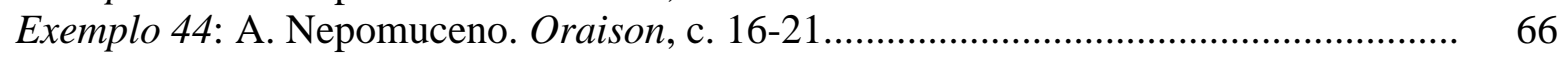

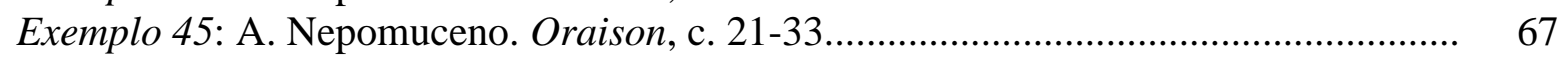

Exemplo 46: A. Nepomuceno. Desterro, c. 6-11 e c. 23-24......................................... 71

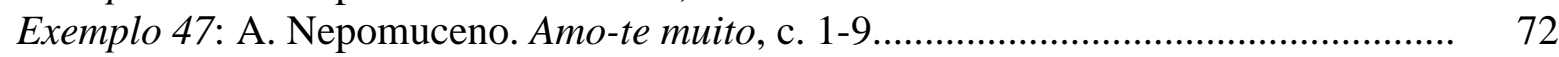

Exemplo 48: F. Mendelssohn. Canção sem palavras Op. 53 no 2, c. 1-9........................ 73 
Exemplo 49: A. Nepomuceno. Ora dize-me a verdade, c. 8-11..................................... 74

Exemplo 50: A. Nepomuceno. Ora dize-me a verdade, c. 1-8....................................... 75

Exemplo 51: A. Nepomuceno. Ora dize-me a verdade, c. 8-11 ..................................... 76

Exemplo 52: A. Nepomuceno. Mater dolorosa, c. 1-4.................................................... 77

Exemplo 53: A. Nepomuceno. Mater dolorosa, c. 9-12 ................................................. 77

Exemplo 54: A. Nepomuceno. Mater dolorosa, c. 17-20............................................ 78

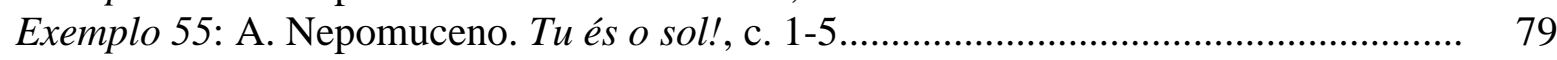

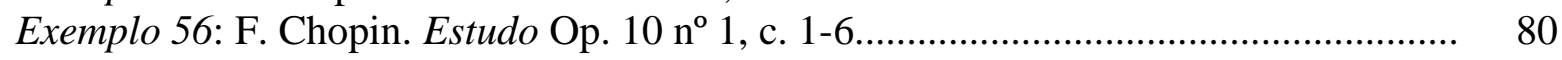

Exemplo 57: F. Chopin. Estudo Op. 25 n $^{\circ} 12$, c. 1-6.................................................... 81

Exemplo 58: A. Nepomuceno. Tu és o sol!, c. 21-29 .................................................... 82

Exemplo 59: A. Nepomuceno. Ora dize-me a verdade, c. 1-2, e Amo-te muito, c. 1-2... 83

Exemplo 60: A. Nepomuceno. Tu és o sol!, c. 1-2, e Mater dolorosa, c. 1-2 .................. 83

Exemplo 61: A. Nepomuceno. Medroso de amor, c. 1-7............................................... 86

Exemplo 62: A. Nepomuceno. Medroso de amor, c. 10-15.......................................... 87

Exemplo 63: A. Nepomuceno. Medroso de amor, c. 10-11........................................... 88

Exemplo 64: A. Nepomuceno. Madrigal, c. 5-13....................................................... 89

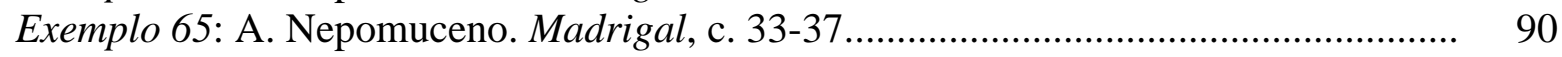

Exemplo 66: A. Nepomuceno. Madrigal, c. 62-66...................................................... 91

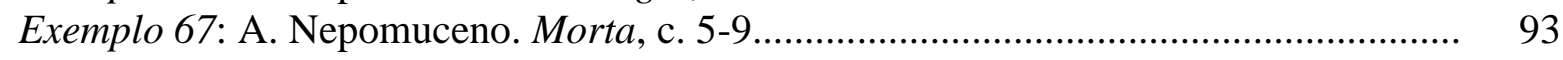

Exemplo 68: A. Nepomuceno. Morta, c. 12-15......................................................... 93

Exemplo 69: A. Nepomuceno. Morta, c. 24-28 .............................................................. 93

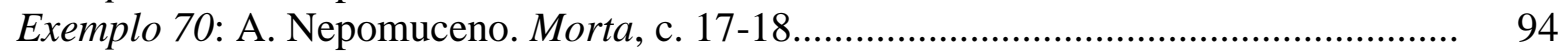

Exemplo 71: A. Nepomuceno. Cantos da Sulamita, c. 5-8 ............................................. 94

Exemplo 72: A. Nepomuceno. Sonhei, c. 11-18........................................................... 95

Exemplo 73: A. Nepomuceno. Canção de amor, c. 3-8................................................. 96

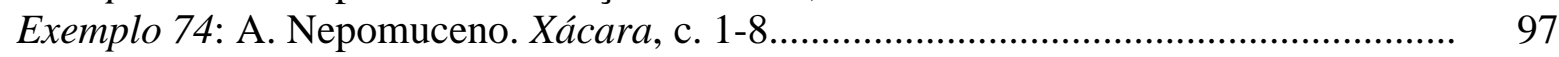

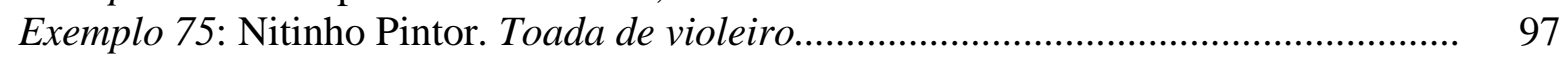

Exemplo 76: A. Nepomuceno. Oração ao diabo, c. 1-16.............................................. 99

Exemplo 77: A. Nepomuceno. Oração ao diabo, c. 17-22 ............................................ 100

Exemplo 78: A. Nepomuceno. Oração ao diabo, c. 23-25............................................. 101

Exemplo 79: A. Nepomuceno. Oração ao diabo, c. 33-36.............................................. 101

Exemplo 80: A. Nepomuceno. Oração ao diabo, c. 38-43 ............................................... 102

Exemplo 81: A. Nepomuceno. Oração ao diabo, c. 26-37 ............................................. 102

Exemplo 82: A. Nepomuceno. O sono, c. 1-2 …......................................................... 103

Exemplo 83: A. Nepomuceno. Dolor supremus, c. 1-5............................................... 104

Exemplo 84: A. Nepomuceno. Coração triste, c. 3-6..................................................... 104

Exemplo 85: A. Nepomuceno. Soneto, c. 1-8........................................................... 105

Exemplo 86: A. Nepomuceno. Turquesa, c. 1-6..................................................... 106

Exemplo 87: A. Nepomuceno. Hidrófana, c. 1-3....................................................... 106

Exemplo 88: Anônimo. Rochedo, Sinhá (Coco) e Pae Cajuê (Toada)........................... 107

Exemplo 89: A. Nepomuceno. Trovas I, c. 1-8.............................................................. 108

Exemplo 90: A. Nepomuceno. Trovas I, c. 12-21 .......................................................... 109

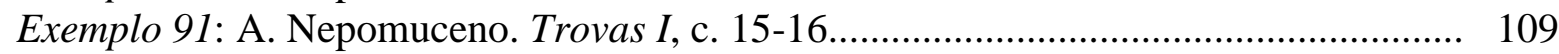

Exemplo 92: A. Nepomuceno. Trovas I, c. 29-32 ......................................................... 110

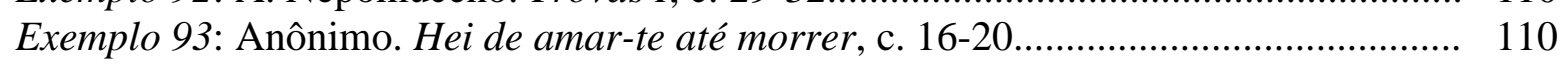

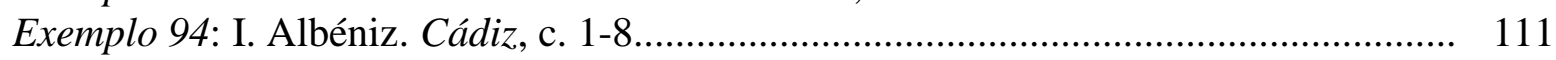

Exemplo 95: A. Nepomuceno. Trovas II , c. 1-6....................................................... 112

Exemplo 96: A. Nepomuceno. Trovas II, c. 38-40.................................................. 112

Exemplo 97: A. Nepomuceno. Cantigas, c. 1-8.......................................................... 114

Exemplo 98: A. Nepomuceno. Cantilena, c. 1-7..................................................... 115 
Exemplo 99: Anônimo. Coração Santo 115

Exemplo 100: A. Nepomuceno. Cantilena, c. 1-5.

Exemplo 101: A. Nepomuceno. Coração indeciso, Op. 30 nº 1, c. 1-7.....

116

Exemplo 102: A. Nepomuceno. Coração indeciso, Op. $30 \mathrm{n}^{\circ}$ 1, c. 13-17......

117

Exemplo 103: A. Nepomuceno. Canção, Op. 30 no 2, c. 1-4, 15-18, 29-32 e 41-44....... 118

Exemplo 104: A. Nepomuceno. A grinalda, Op. 31 no 1, c. 1-3....................................... 119

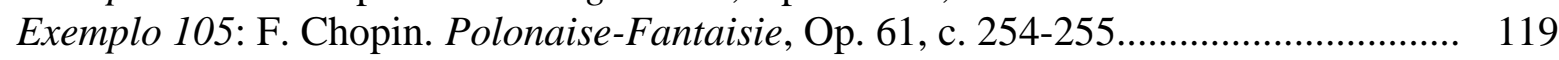

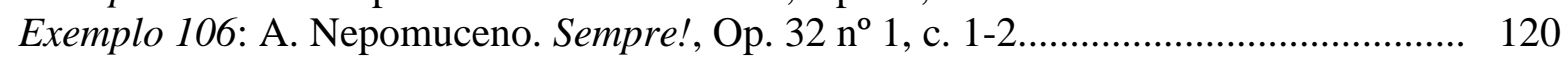

Exemplo 107: F. Chopin. Estudo Op. 10 no 9, c. 1-4.................................................... 120

Exemplo 108: R. Schumann. An meinem Herzen, an meiner Brust, Op. 42 nº 7, c. 1-3... 120

Exemplo 109: A. Nepomuceno. Despedida, Op. 31 n $^{\circ}$ 2, c. 1-3 .................................... 121

Exemplo 110: A. Nepomuceno. Dor sem consolo, Op. 32 n 2, c. 1-5 ............................ 121

Exemplo 111: R. Schumann. Intermezzo, Op. 39 n 2 , c. 1-3 ........................................ 122

Exemplo 112: F. Schubert. Der König von Thule, c. 1-8.............................................. 122

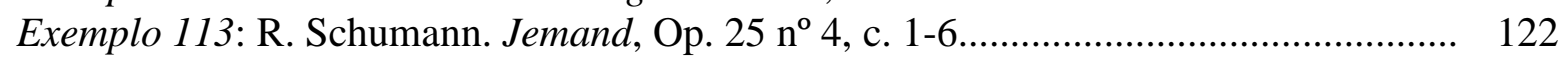

Exemplo 114: A. Nepomuceno. Canto nupcial, c. 5-13 ................................................ 125

Exemplo 115: A. Nepomuceno. Canto nupcial, c. 33-36............................................ 125

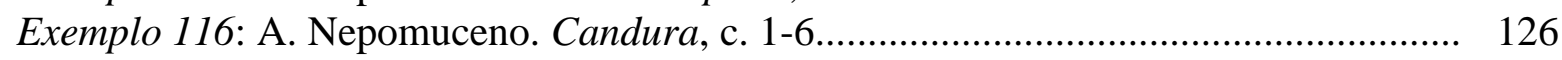

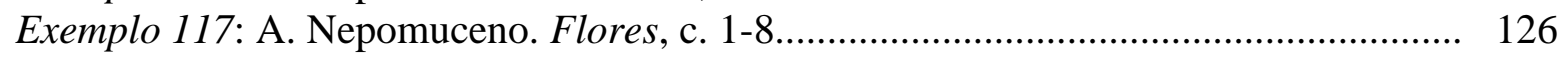

Exemplo 118: A. Nepomuceno. Nossa velhice, c. 27-38.............................................. 128

Exemplo 119: A. Nepomuceno. Aime-moi, c. 1-8.......................................................... 129

Exemplo 120: A. Nepomuceno. Drömd lycka, c. 1-3 .................................................... 129

Exemplo 121: A. Nepomuceno. Razão e amor, c. 8 e 9.................................................... 130

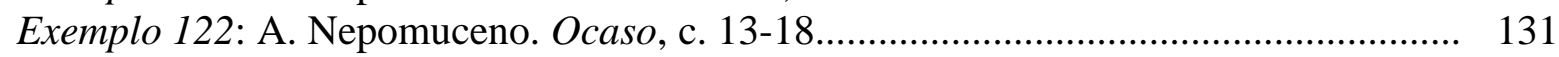

Exemplo 123: F. Chopin. Polonaise-Fantaisie, Op. 61, c. 254-255................................ 131

Exemplo 124: A. Nepomuceno. Mater dolorosa, c. 20-24.......................................... 132

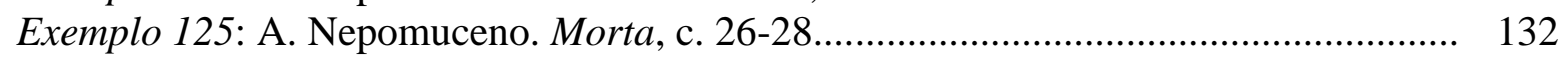

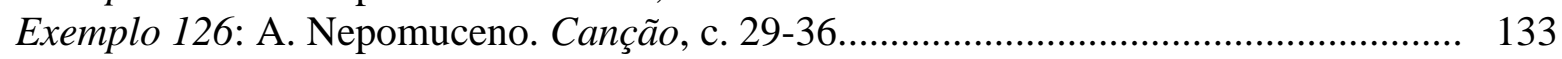

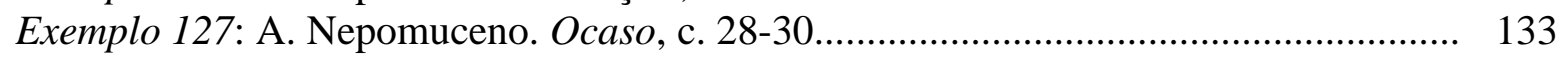

Exemplo 128: A. Nepomuceno. Numa concha, c. 1-3............................................... 134

Exemplo 129: A. Nepomuceno. Olha-me, c. 1-5 ........................................................... 134

Exemplo 130: A. Nepomuceno. Canção da ausência, c. 1-4......................................... 135

Exemplo 131: A. Nepomuceno. Luz e névoa, c. 1-3 ....................................................... 135

Exemplo 132: A. Nepomuceno. Canção da ausência, c. 16-27........................................ 136

Exemplo 133: A. Nepomuceno. Luz e névoa, c. 24-31................................................... 137

Exemplo 134: A. Nepomuceno. Canção do rio, c. 1-8..................................................... 138

Exemplo 135: A. Nepomuceno. A jangada, c. 5-8 ...................................................... 141

Exemplo 136: F. Schubert. Ave Maria, c. 3-4............................................................. 141

Exemplo 137: C. Debussy. En bateau (Petite Suite $n^{o} 1$ ), c. 1-5.................................. 142

Exemplo 138: A. Nepomuceno. A jangada, c. 25-28 .................................................... 142

Exemplo 139: A. Nepomuceno. A jangada, c. 1-4 ....................................................... 143

Exemplo 140: A. Nepomuceno. A jangada, c. 13-17..................................................... 143 


\section{SUMÁRIO}

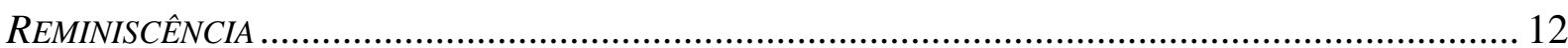

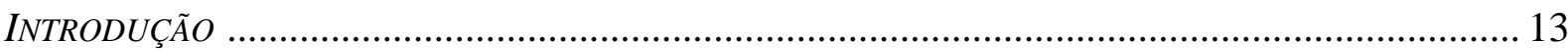

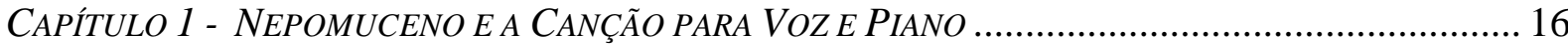

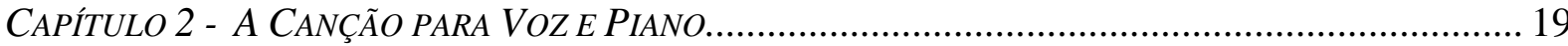

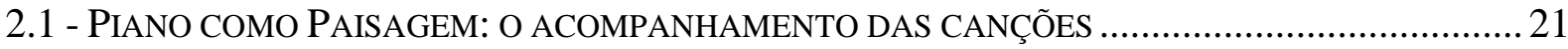

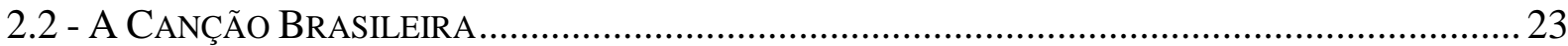

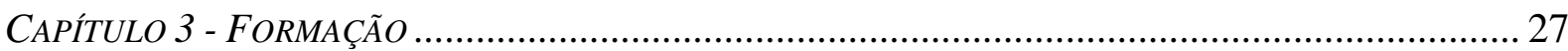

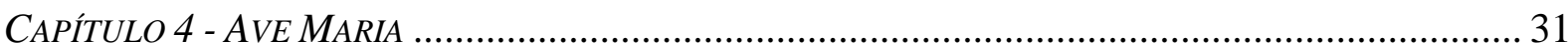

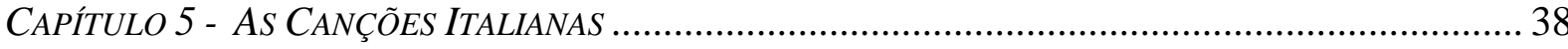

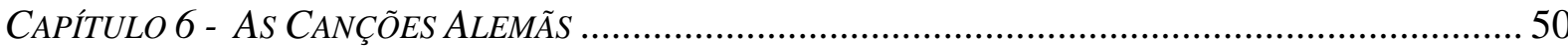

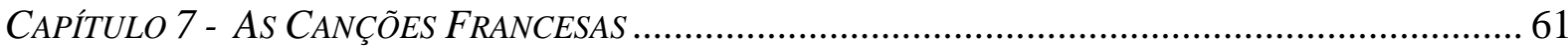

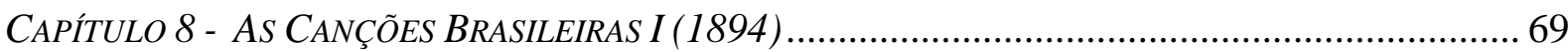

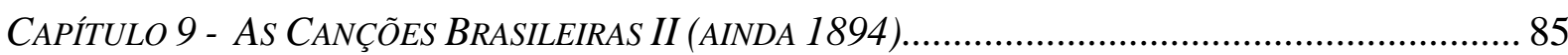

CAPÍTULO 10 - AS CANÇÕES BRASILEIRAS III (1896-1897) ...................................................... 92

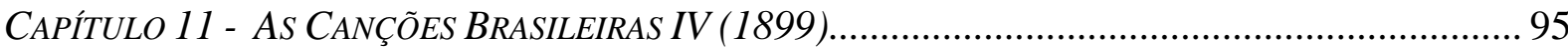

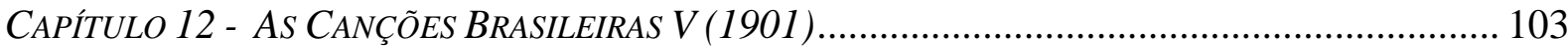

CAPÍTULO 13 - AS CANÇÕES BRASILEIRAS VI (1902-1904) ...................................................... 113

CAPÍTULO 14 - AS CANÇÕES BRASILEIRAS VII (1907-1915) ...................................................... 124

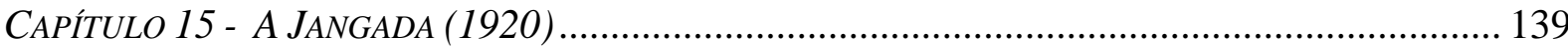

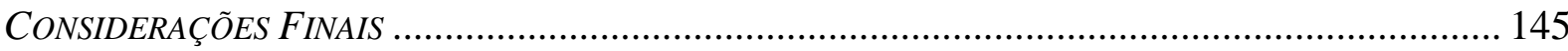

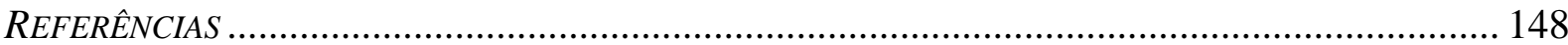




\section{REMINISCÊNCIA}

Em 1997 tive a oportunidade de apresentar um programa de canções brasileiras em Berlim acompanhando a soprano Katia Guedes, minha colega de faculdade em tempos idos e companheira querida e entusiasmada nas aventuras musicais desde a juventude. Tratava-se de um panorama da canção brasileira que ia de uma modinha do Padre José Maurício Nunes Garcia, Beijo a mão que me condena, ao rock Astronauta Perdido do Arrigo Barnabé, em arranjo feito pelo próprio especialmente para nós. Na capital da Prússia, antes de uma apresentação importante, tocamos algumas das peças do programa para a professora de Katia na Hochschule der Künste, Inge Uibel. Entre essas canções figuravam duas de Alberto Nepomuceno, Cantigas, obviamente brasileira, e Trovas I. Após os comentários técnicos pertinentes, lembro-me que Katia, um pouco sem graça e quase se desculpando, mencionou à ilustre professora que Trovas, se bem que em português, era música européia. Frau Uibel reagiu prontamente, afirmando que de forma alguma aquilo era música européia. Era música brasileira!

Quando pela primeira vez me debrucei deslumbrado sobre as canções de Nepomuceno, as palavras da mestra alemã me vieram de súbito à mente, com a questão: por que, aos nossos ouvidos brasileiros, aquela música soava européia, enquanto para experimentados ouvidos europeus ela soava brasileira?

Este trabalho é uma tentativa de resposta. 


\section{INTRODUÇÃO}

A gênese deste trabalho se deu em 1997. Celebrava-se então o bicentenário de nascimento de Franz Schubert e a Rádio Cultura FM de São Paulo, onde eu tinha começado a trabalhar no final do ano anterior, deu grande destaque à efeméride. Eu, como produtor, fui responsável pela apresentação da obra completa do compositor austríaco, ou pelo menos boa parte dela, além de uma série mais elaborada intitulada "Lied: a canção romântica alemã", que era apresentada por Carlos Siffert e que rendeu mais de quarenta programas.

Meu interesse pela canção de arte vinha de longa data (o gênero me atraía desde os tempos de estudante), e após essa verdadeira imersão em Schubert em particular e no lied em geral, era natural que me voltasse para o universo da canção em minhas pesquisas. Eu pretendia escrever sobre a relação entre música e palavra ou, mais especificamente, sobre o acompanhamento pianístico das canções. Sendo brasileiro e estando no Brasil, fazia-se necessário pelo menos um capítulo sobre a canção brasileira, universo que eu então praticamente desconhecia. Ao pesquisar sobre canção brasileira, o nome de Alberto Nepomuceno emergiu quase de imediato. Em seguida entrei em contato com Sérgio Alvim Corrêa, neto do compositor e autor do Catálogo Geral de suas obras. Ele respondeu prontamente, e em questão de dias chegavam-me pelo correio pacotes com cópias das partituras das canções. Quando me dei conta da magnitude e sobretudo da qualidade daquele material, decidi nele concentrar-me. Em 2004, um patrocínio da Petrobras me permitiu editar as canções para voz e piano de Nepomuceno, o que me forçou a estudar essas partituras literalmente nota a nota.

O meu campo de pesquisa, portanto, foram fundamentalmente os textos musicais das próprias canções. Comecei pela última, A Jangada, quando, ouvindo uma gravação, um lampejo me fez ver a representação quase gráfica, a la Schubert, de uma jangada singrando o mar nordestino. Em seguida veio Perchè?, cuja aparente simplicidade me enganou por um bom tempo. A partir daí, passei a analisar essas canções de maneira sistemática, aperfeiçoando a técnica e adquirindo ferramentas mais precisas ao longo do caminho. Como base teórica para essas análises, tomei por modelo sobretudo o ecletismo pragmático de Charles Rosen e a idéia de janelas hermenêuticas desenvolvida por Lawrence Kramer. A atividade simultânea como pianista, professor de história da música e criador de programas de rádio me levou a estudar um grande número de partituras e gravações de todos os gêneros e 
épocas e determinou uma visão evolutiva da música, uma espécie de geologia de camadas superpostas de significado.

A idéia principal, minha tese fundamental, de que Nepomuceno valeu-se da musicalidade inerente ao idioma para flexionar a linguagem musical européia e assim criar música brasileira surgiu em primeiro lugar, ainda de forma nebulosa, do episódio descrito na Reminiscência, que se confirmaria mais tarde quando me deparei com o lema atribuído a Nepomuceno, "Não tem pátria o povo que não canta em sua língua."

Esse processo de "abrasileiramento" da linguagem musical por meio do idioma falado e cantado é ao mesmo tempo evidente à audição e extremamente elusivo quando tentamos apontar com precisão para o mecanismo operando em um trecho de música determinado. De alguma maneira, essa musicalidade "nacional" foi absorvida pelo compositor durante a infância e a juventude e é vertida de forma difusa e generalizada nas ambientações de textos em português. Nas análises, que formam o corpo central deste trabalho, tentei em cada caso isolar e mostrar os elementos a meu ver mais importantes que se integram na composição, e é a interação desses elementos com essa brasilidade musical inerente à língua e ao entendimento musical do compositor que configura, no cancioneiro, o que chamo de estilo pessoal de Alberto Nepomuceno.

Este trabalho está dividido em três partes.

Três capítulos formam a primeira delas. No primeiro, tento mostrar como o compositor buscou criar música brasileira a partir da língua falada e cantada no Brasil, colocando o foco dessa criação nas relações entre texto e música. Ao fazê-lo, comparo a posição que Nepomuceno ocupa nos estudos de musicologia de Mário de Andrade e nos de Avelino Romero Pereira, que deu início a uma revisão do significado da obra do compositor cearense e da posição que ocupa na história da música brasileira.

O segundo capítulo é uma história resumida da canção erudita, onde procuro mostrar sua definição enquanto gênero. Aqui tentei situar as canções de Nepomuceno em um painel que começa com a eclosão do lied romântico, passa pelo surgimento da mélodie francesa e culmina com a gênese da canção brasileira a partir da modinha. 
O terceiro capítulo está dedicado à formação intelectual e ideológica do compositor, destacando-se sua vinculação à chamada Escola do Recife e as consequências dessa vinculação para sua atividade criadora.

A segunda parte consiste de quatro capítulos. Aqui são analisadas Ave Maria, a primeira composição para voz e piano de Nepomuceno, e as canções em idioma estrangeiro realizadas durante sua estadia na Europa.

No primeiro desses capítulos analiso a primeira canção publicada por Nepomuceno. Extensa e detalhada, essa análise está centrada principalmente nos aspectos harmônicos e formais e procura revelar a bagagem musical levada pelo compositor em sua viagem de estudos à Europa e também como, já nessa primeira ambientação de um texto em português, elementos formais e rítmico-melódicos europeus e "nacionais" se mesclam, compondo um exemplo juvenil do estilo pessoal do compositor. Nos capítulos seguintes eu analiso as canções em italiano, alemão e francês, respectivamente.

Na terceira parte do trabalho, a mais extensa, com oito capítulos, são estudadas as canções em português, apresentadas em ordem cronológica, como de resto também o são as que integram a seção anterior. Dados biográficos interligam os capítulos e ajudam a esclarecer a gênese das canções e também seu significado.

Minhas conclusões estão resumidas no capítulo final.

Todas as traduções de idiomas estrangeiros são de minha autoria e de minha exclusiva responsabilidade. 
CAPÍtulo 1 - NEPOMUCENo e a CANÇÃo PARA Voz E PIANO

Nepomuceno compôs canções com acompanhamento de piano ao longo de toda a vida, totalizando cerca de 70 peças. A primeira, Ave Maria, é de 1887, e encontra-se entre as primeiras obras que publicou; a última, A Jangada, foi escrita no leito de morte, em 1920. Uma trajetória é traçada por estas canções, e seu estudo revela um projeto claramente definido: a criação de uma música brasileira.

O nacionalismo musical de Nepomuceno é de ordem diversa daquele que seria defendido posteriormente pelos modernistas. O grito de guerra a ele atribuído, "Não tem pátria o povo que não canta em sua língua”, dá a medida da importância que o cancioneiro tem em sua obra, como salienta Avelino Pereira:

\begin{abstract}
Nepomuceno conheceu altos e baixos. Foi vaiado em Roma, na estréia de uma ópera, e aplaudido por estudantes em greve em solidariedade ao diretor demissionário. Foi festejado por seus pares e achincalhado por seus críticos. Viveu sucessos e fracassos. Talvez, o maior sucesso de sua vida tenha sido a opção consciente que fez na defesa do canto em língua portuguesa, abrindo os ouvidos para a afirmação da canção acadêmica em português e marcando definitivamente a história da música brasileira. Dizem os biógrafos de Alberto Nepomuceno que ele teria cunhado um lema: 'não tem pátria um povo que não canta em sua língua'. Nepomuceno, provavelmente, nunca disse isso, mas é bem provável que pensasse assim. Assim pensavam as correntes nacionalistas de origem ou inspiração alemã, às quais Nepomuceno, como tantos intelectuais de sua geração, devia sua formação política e cultural.

Para essa espécie de nacionalismo [...] a nação era um fenômeno natural, condicionado pelo local de nascimento, a 'raça', a tradição e a língua. Natureza e cultura formando uma coisa só.

[...] não se pode negar o papel que a afirmação da língua exerce sobre a constituição da identidade cultural e social das coletividades humanas. E, nesse sentido, pode-se afirmar que de fato Nepomuceno assumiu a composição de canções e obras corais e dramáticas em português como um projeto estético - e político, é claro. (PEREIRA, 2000, p. XVIII-XIX).
\end{abstract}

Para nosso compositor, a via para a constituição de uma música brasileira não era a da apropriação do folclore nacional, ou não apenas isso. Nepomuceno acreditava que a música brasileira deveria ser extraída do idioma português falado e cantado no Brasil, uma abordagem sutil, sofisticada e, provavelmente, em grande parte instintiva e inconsciente. Mário de Andrade sabia da íntima relação que existe entre texto falado e cantado:

Me parece sistemático. Há uma tal ou qual relação entre a beleza das canções e sua perfeição fonética, e sobre isto os compositores deveriam matutar mais. Os seus cantos mais inspirados, mais bonitos e [...] mais cantados são os que derivam mais imediatamente do texto falado. Parece haver uma conexão lógica entre a resultante beleza da melodia e a resultadora perfeição fonética do texto quando falado. (ANDRADE, 1991, p. 64). 
Tal relação entre texto e música faz com que o idioma inevitavelmente molde a melodia ${ }^{1}$. Nepomuceno nacionaliza a música utilizando sistematicamente textos em português em suas canções, e nesse exercício vai flexionando as tradições musicais européias e cria o primeiro cancioneiro erudito brasileiro. Nas criações para voz e piano de Nepomuceno observamos uma mescla única de música popular urbana e também folclórica, recitativo wagneriano, modinha, lied, ópera italiana, mélodie... Esse amálgama de elementos aparentemente díspares, catalizado pelo idioma, resulta num estilo único e inequivocamente brasileiro (ver Introdução).

Mário reconhece a importância de Nepomuceno e conhecia bem seu cancioneiro, como demonstram as análises que faz em Os Compositores e a Língua Nacional (ANDRADE, 1991). Em Evolução Social da Música no Brasil, Mário musicólogo insere o esforço de Nepomuceno no contexto internacional da época:

Pois era na própria lição européia da fase internacionalista que Alexandre Levy e Alberto Nepomuceno iam colher o processo de como nacionalizar rápida e conscientemente, por meio da música popular, a música erudita de uma nacionalidade. Já então o Grupo dos Cinco na Rússia, criando sistematicamente sobre as manifestações musicais populares do seu espantoso país, tinham conseguido nacionalizar e tornar independente a música russa. A música espanhola, por seu lado, já criara e definira nacionalmente a zarzuela, mas sempre é certo que Albéniz e Granados ainda eram apenas contemporâneos dos nossos dois compositores. Mas, em compensação, o exemplo da Alemanha pesava enormemente ao lado do russo; e já então, além da nacionalização definitiva do lied com Schubert e Schumann, a música sistematicamente tradicionalista e mesmo voluntariamente nacionalista de Brahms e especialmente de Wagner, estava quase agressivamente, quase hitleristamente firmando a consciência musical germânica, sempre tendo por base o lied nacional. Esta nacionalização por meio da temática popular foi o que tentaram Alexandre Levy e Alberto Nepomuceno. E neste sentido, embora ainda deficientemente, eles não são apenas profetizadores da nossa brilhante e inquieta atualidade, mas a ela se incorporam, formando o tronco tradicional da árvore genealógica da nacionalidade musical brasileira. (ANDRADE, 1991, p. 24, grifo nosso).

Avelino Pereira situa Nepomuceno na tradição musicológica brasileira e procura retificar a visão que ainda se tem de sua obra:

Na tradição de estudos sobre a música brasileira, Alberto Nepomuceno aparece como um 'precursor' do nacionalismo musical, escrevendo música de 'caráter nacional'. Segundo essa tradição, a parte interessante de sua obra são as peças em que o

\footnotetext{
${ }^{1}$ Ao estudar relação entre fala e música, Luiz Tatit vincula a canção popular à dicção e mostra com proficuidade técnica as maneiras em que a canção popular se origina da dicção, ou melhor, nela se molda (TATIT, 2002). Do lado erudito, Lawrence Kramer considera a relação entre poesia e música tão íntima a ponto de propor a criação de uma disciplina única que permita abordar ambas as artes indistintamente. (KRAMER, 1984).
} 
cearense exercitou o ofício de compor a partir das tradições musicais rurais ou urbanas do país. A conseqüência é a desqualificação e o esquecimento da maior parte de sua obra e também a dificuldade em se compreender seu papel no contexto histórico-cultural em que viveu.

$[\ldots]$

A questão orientadora é entender por que Nepomuceno é visto como 'precursor', expressão que, se por um lado parece valorizá-lo, por outro, compromete a compreensão de seu papel, ao retirar dele seu sentido próprio, deslocando este sentido para um momento posterior àquele em que viveu e compôs. 'Precursor' de quê? Do nacionalismo modernista que se desenvolveu e se tornou hegemônico na música brasileira entre as décadas de 1920 e 1950 e que teve em Heitor Villa-Lobos seu expoente máximo. O resultado disso é que Nepomuceno passou a ser ouvido com os ouvidos de quem ouve Villa-Lobos e deseja ouvir de Nepomuceno o que ele não quis, não soube ou não pôde cantar. (PEREIRA, 2007, p. 21-22).

De fato, para Mário a nacionalização da música somente foi lograda no Brasil por Heitor Villa-Lobos:

Com a nacionalização do lied brasileiro, Villa-Lobos, seus pares e sucessores se tornaram imediatamente muito mais plásticos ritmicamente, na língua de suas canções. A dicção botou corpo, unida, cheia, ao mesmo tempo que se enriqueceu muito de sutilezas e carícias de ritmo. (ANDRADE, 1991, p. 91) ${ }^{2}$.

A abordagem de Nepomuceno não se alinha a esse folclorismo; somente algumas poucas canções distribuídas de forma esporádica no conjunto de sua obra utilizam elementos explicitamente "brasileiros". Por outro lado, é certo que a atitude de Nepomuceno alinha-se à onda nacionalista que impulsionou o romantismo europeu no século 19. Abordar as canções de Nepomuceno é também adentrar a questão da criação de uma música nacional a partir das tradições da música erudita européia e ir de encontro às raízes românticas da música brasileira.

\footnotetext{
${ }^{2}$ Mário matizaria sua posição mais tarde. Em ensaio inédito de 1944 sobre as 13 Canções de Amor de M. Camargo Guarnieri, ele escreve: "Nisto talvez esteja uma das grandes forças que tornam tão íntegra e excepcional a lírica de G. dentro da lírica contemporânea nacional. É que os outros, o próprio Vila e também F. Mignone, quando não estão popularescos, lembram o estrangeiro, Debussy, a melódica moderna da lírica italiana e francesa em principal. G. ao contrário lembra a nossa melódica erudita em língua nacional, Braga, Barroso Neto, Nepomuceno, e mais raro o estrangeirizante Oswald. Que quererá isto dizer? A meu ver tem uma significação profunda. Talvez, com efeito, se dissermos a C. G. que ele se parece com Braga, Nepom. e Barroso ele fique muito chocado, decepcionado e revoltado, porque se sente, e com razão, a dez léguas adiante dessa geração e mesmo a conhece pouco e a estudou quase nada. É que a semelhança, a quase 'imitação' nas 13 Canções, não deriva senão de uma coincidência linda. Tanto aqueles como G. se puseram a melodizar, não na inexpressividade de assunto da melodia popular (o que não quer dizer que o folclore seja inexpressivo), mas na expressividade erudita da canção, já muito mais próximos (nisso) de um Schumann e de um Hugo Wolf, que de um Schubert e mesmo de um Brahms. Ora essa expressividade musical estava obrigada a se condicionar à língua nacional, aos seus valores sonoros e ritmos naturais. E foi pois desse condicionamento bem realizado, dessa adequação melo-verbal que derivou um parentesco muito íntimo e sutil. O que reverte em grande elogio para os Barroso Neto, Bragas e Nepomucenos, iniciadores da melódica cancioneira erudita nacional.” (In: BARONGENO, 2007, p. 88-89).
} 
A relação íntima entre poesia e música no Ocidente vem se consumando desde a Grécia clássica, onde a épica (Homero, por exemplo) era cantada por um solista, enquanto os versos líricos (as odes de Píndaro, por exemplo) eram entoadas pelo coro (CANISIUS, 1998, p. 36). Entretanto, na segunda metade do século 18 e especialmente nas primeiras décadas do 19 eclode, na Alemanha e na Áustria, um fenômeno único: o lied romântico.

Embora tenhamos exemplos anteriores, dentre os quais se destacam algumas canções de Mozart, é a partir de Schubert e da maior importância conferida ao acompanhamento pianístico que o lied ganha importância como gênero e se difunde por toda a Europa. Não somente a parte do piano se torna mais complexa; o mesmo acontece com as múltiplas interrelações entre piano e voz e entre música e poesia. Guardadas as características culturais peculiares às respectivas nações, esse processo de sofisticação crescente que paulatinamente transforma gêneros estróficos mais populares em canção de arte se repete tanto na França como no Brasil.

O lied romântico reflete diretamente o renascimento da poesia lírica alemã, combinando os estilos e temas de outros gêneros vocais tais como a cantata e a ópera com os da canção folclórica ou tradicional, para então reduzi-los em termos de voz e teclado (SAMS, 1980, p. 838). Os recursos plásticos utilizados pelos compositores são variados, indo da representação quase pictórica de uma roca de fiar em movimento (pedal incluído) em Gretchen am Spinnrade, de Schubert... 
EXEMPLO 1: F. SCHUBERT. Gretchen am Spinnrade, c. 1-9
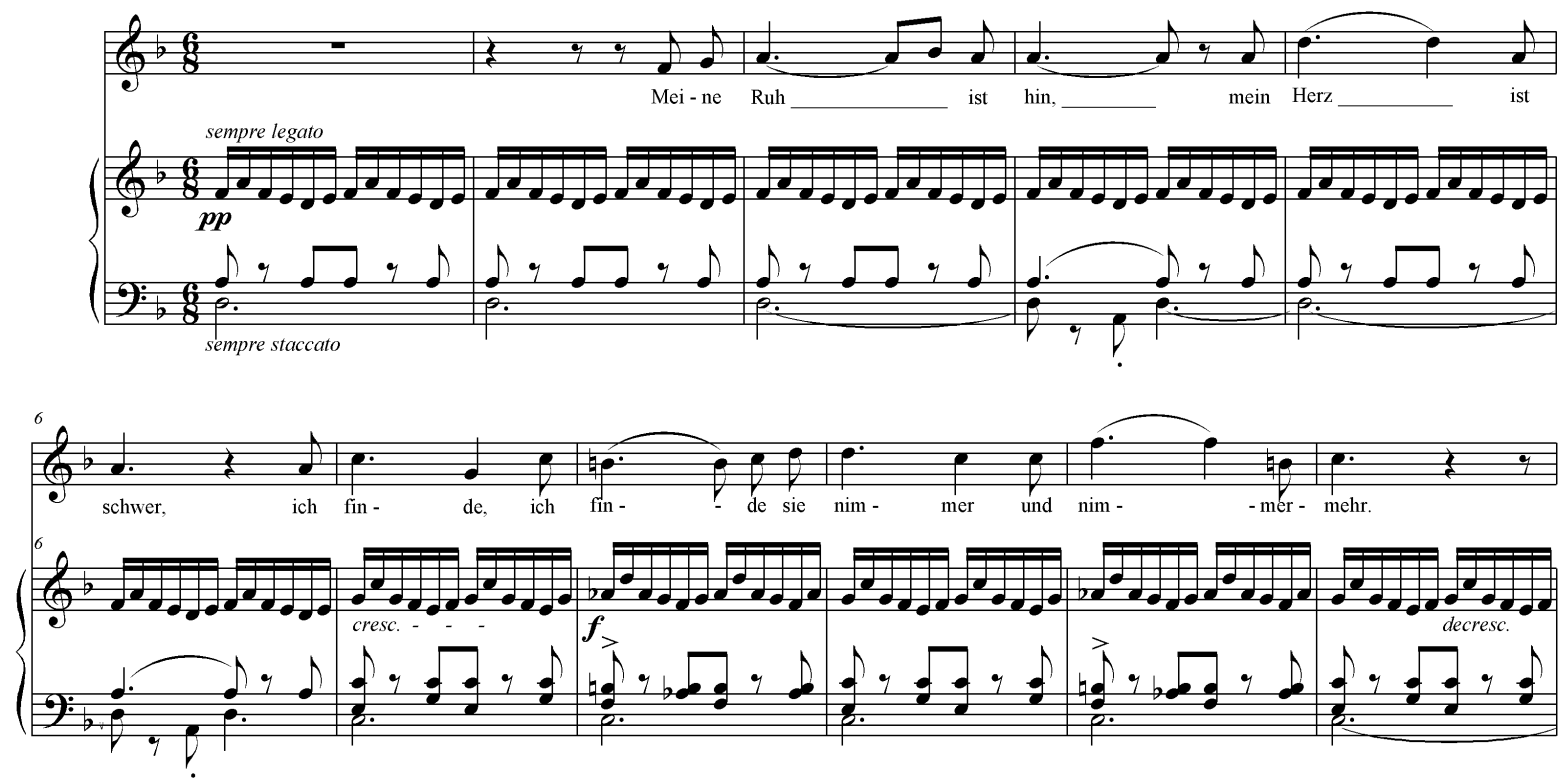

FISCHER-DIESKAU/BUDDE (Ed.). Schubert: Lieder, vol. II. Frankfurt: C. F. Peters, 1986, p. 10.

... à encenação metafísica do casamento místico da Terra e do Céu feita por Schumann em Mondnacht (op. $39 \mathrm{n}^{\circ}$ 5), onde nas duas primeiras notas o piano define os dois protagonistas para, um pouco adiante (compassos ${ }^{3}$ 10-11), sublinhar com as notas mi - si - mi (em alemão: e-h-e) as palavras céu e terra (Himmel e Erde) na segunda metade do primeiro verso, Es war als hätt' der Himmel die Erde still geküßt (= É como se o céu a terra calmamente beijasse), escrever Ehe (= casamento) descendentemente na parte do baixo do piano e, assim, expressar também seu desejo de unir-se em matrimônio a Clara Wieck ${ }^{4}$ :

\footnotetext{
3 A partir daqui, será usada sempre a abreviatura "c." para a palavra "compasso", no singular ou no plural.

${ }^{4}$ À época da composição de Mondnacht (1840), Schumann aguardava uma decisão judicial para poder casar-se com Clara Wieck. As canções que compõem o Liederkreis Op. 39, em rica encadernação, foram entregues por Schumann a Clara como presente de casamento.
} 

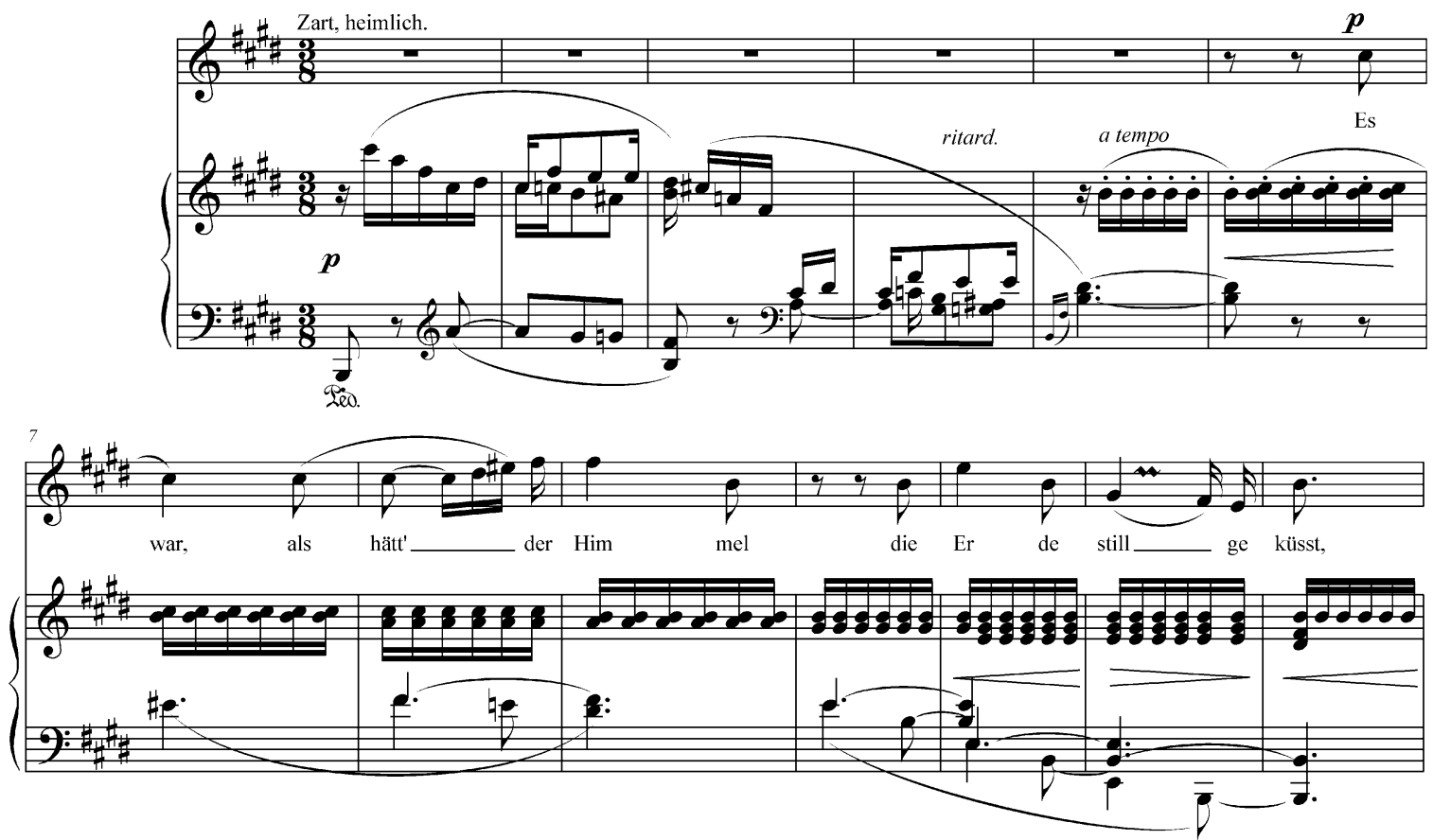

FRIEDLAENDER, Max (Ed.). Sämtliche Lieder. Leipzig: C. F. Peters, ano (?), p. 68.

Com o lied, a canção torna-se um gênero quase cênico em que a voz é personagem de uma seqüência narrativa encenada em uma paisagem pianística.

\subsection{PIANO COMO PAISAGEM: O ACOMPANHAMENTO DAS CANÇÕES}

Uma canção é necessariamente uma interpretação da palavra pela música. Ainda que não modifique o texto poético - e isso foi feito em diversas ocasiões - o compositor termina privilegiando determinados aspectos do poema. Essa interpretação se expressa sobretudo na ambientação proporcionada pelo acompanhamento pianístico.

O surgimento do lied, por um lado, está diretamente relacionado a Goethe e ao processo de reciclagem da poesia folclórica que empreende, incentivado por seu mentor, Herder, que cunhou o termo Volkslied (canção popular); por outro, ele acontece paralelamente ao processo de aperfeiçoamento do piano e a conseqüente superação do cravo e do clavicórdio, que passa a dar-se com maior intensidade a partir de 1770. A superioridade das possibilidades expressivas do novo instrumento (PIGNATARI, 1992) permite a elevação do acompanhamento das canções a um nível de paridade com a poesia: 
No século XIX, a canção vernacular alemã torna-se uma forma de arte em que as idéias musicais sugeridas pelas palavras materializam-se na adaptação dessas palavras para voz e piano, tanto para obter unidade formal quanto para realçar os detalhes. [...] O gênero pressupõe um renascimento da poesia lírica alemã, a popularidade dessa poesia entre compositores e público, um consenso de que a música pode derivar das palavras e um acervo abundante de técnicas e recursos para expressar essa inter-relação. (SAMS, 1980, vol. 10, p. 838, grifo nosso).

Um recurso muito utilizado nas etapas iniciais do desenvolvimento do lied como gênero está caracterizado na literatura especializada como pintura tonal ${ }^{5}$ e definido como "a descrição ou imitação de eventos óticos ou auditivos, impressões, sensações etc, particularmente os que são encontrados na natureza ou na vida cotidiana." (SADIE, 1980, vol. 19, p. 66).

Um vocabulário musical de recursos plásticos, limitado e algo estereotipado, já era empregado nos tempos da Empfindsamkeit e de Carl Philipp Emanuel Bach, em meados do século 18, e até antes, sendo na verdade uma herança do Barroco, mais especificamente da ópera barroca; um exemplo óbvio são trêmolos nos baixos (do instrumento de teclado ou da orquestra) representando uma tempestade, ou o uso de certos instrumentos de percussão e determinados ritmos para dar à música um caráter militar; a "música turca", que chega até Beethoven, é outro desses exemplos. Johann Peter Milchmeyer, no capítulo V de "Die wahre Art das Pianoforte zu spielen" (1797), descreve uma grande variedade de efeitos plásticos que podem ser obtidos pela combinação de determinadas figurações do piano com efeitos de pedal (MILCHMEYER, 1992, p. 96-113).

Nas mãos de Schubert a pintura tonal, um recurso até então marginal e de gosto algo duvidoso, transforma-se em um material infinitamente maleável que passa a integrar a estrutura mesma das canções, constituindo através do acompanhamento de piano um cenário, uma paisagem mental a ser habitada pela poesia veiculada pela voz.

O processo é antecipado por Mozart em 'Das Veilchen' (Goethe) e 'Abendempfindung' (anôn.). [...] Cada uma das ambientações é musicalmente variada mas ainda assim unificada, em resposta ao clima poético, pelo uso do recitativo vocal e do simbolismo do teclado (um leve staccato para a pastora que passeia, sextas suspirantes para os ventos da noite). (SAMS, 1980, vol. 10, p. 839).

\footnotetext{
${ }^{5}$ Pintura tonal: em inglês, tonal painting; em alemão, Tonmalerei.
} 
A partir de Schubert, recursos de pintura tonal tais como os mencionados acima multiplicam-se, diversificam-se e passam a impregnar a concepção mesma da ambientação de poemas, ou seja, da composição de canções. É o acompanhamento das canções de Schubert que impressiona os franceses e contribui para o surgimento da mélodie:

Reichardt foi o primero a dar a este tipo de música aquela variedade, aquela riqueza de harmonia no acompanhamento, que a distingue do romance francês. ... O grande mérito da obra de Schubert reside na concepção profundamente poética das palavras, na originalidade das melodias, na novidade e beleza das harmonias e, sobretudo, na estreita relação entre a canção e seu acompanhamento. As muitas pessoas para quem esta última qualidade é somente um defeito alegam que uma melodia escrita para uma voz solista deveria ser capaz de sustentar-se até mesmo sem um acompanhamento. Este princípio nos parece ser inteiramente falso. Estamos longe de acreditar, no entanto, que o acompanhamento deva dar o significado de cada palavra, que um trêmolo é absolutamente necessário para a palavra "trovão", que a "beira do rio" não pode ser apresentada de maneira apropriada sem um movimento ondulante, e que a palavra "trompete" jamais deve ser encontrada sem a imitação daquele instrumento; está longe de nossa intenção transformar o Lied em música descritiva e assim materializar a arte. Mas devemos defender o princípio que é a base dos acompanhamentos de Schubert: que um sumário do poema, seu caráter, seus vários sentimentos, em uma palavra, a cor do pensamento poético, deve ser representada tanto pelo acompanhamento como pela voz. As mélodies de Schubert são dramáticas; elas não são de modo algum canções para ser cantadas por grisettes ou na caserna, para as quais elas são tão impróprias como o seriam os belos poemas de Lamartine. (PANOFKA, Heinrich, in NOSKE, 1970, p. 33).

\subsection{A CANÇÃo BRASILEIRA}

As raízes da canção brasileira com acompanhamento de piano estão sem dúvida na modinha. Ela se apresenta

[...] como a canção sentimental mais divulgada na vida social portuguesa e brasileira dos século 18 e 19, tendo sido praticada no Brasil até bem entrado o século 20.

Desligadas de qualquer esquema predeterminado, as modinhas, formadas usualmente por versos de oito ou de cinco sílabas, aparecem em várias formas literárias intituladas como Romance, Ária, Arietta, Lira, Hino, etc.; como é lógico, os esquemas literários variam consoante a forma a que pertencem. Sob o ponto de vista formal, não há um critério único: encontramos canções com várias estrofes e estribilho, canções bipartidas, canções contínuas e até canções com a forma dacapo. Entretanto, há um aspecto característico no que se refere ao conteúdo, que apresenta constantemente desgostos de amor, saudades e cuidados à volta da pessoa amada. (DODERER, 1984, p. VII).

Ou nas palavras de Mário de Andrade: 
Porque a modinha nossa, da mesma forma que a portuguesa, é um quase ininterrupto suspiro de amor. Queixume inofensivo, está claro, só com raríssima exceção denunciando alguma dor pelo menos mais musicalmente verdadeira. Rojão de lágrimas, de ais, lamentos e saudades, com a única função de divertir a gente. É mesmo o que diz um texto, já popular, que se cantava com a música da celebérrima "Chiquinha si eu te pedisse..."

"O pinho não se consome,

O que é um dia de fome?

Uma modinha num ai,

Distrai."

(ANDRADE, 1930, p. 5).

O uso caracteristicamente impreciso dos modos maior e menor colabora para formar o caráter sentimental agridoce típico das modinhas brasileiras.

Sua origem é controversa. José Ramos Tinhorão defende uma origem popular da modinha. Já Mário de Andrade, e também Luiz Heitor Correia de Azevedo, defendem uma derivação mais ou menos direta da ópera italiana. Aparentemente, a modinha é produto da conjunção de elementos da arte do canto erudito europeu e dos folclores português e brasileiro. De qualquer modo, as práticas da música vocal européia se infiltram nas modinhas escritas pelos compositores eruditos.

Até então os compositores que produziam modinhas e lundus eram os mesmo que faziam Missas para a Capela Imperial ou óperas para o Teatro Lírico Fluminense: José Maurício Nunes Garcia, Francisco Manuel da Silva, Cândido Inácio da Silva, J. S. Arvelos, Elias Álvares Lobo, Carlos Gomes [...] (AZEVEDO, 1956, p. 138).

O próprio Luiz Heitor descreve o processo de aburguesamento da modinha popular:

[...] o gosto pela música teatral se havia tornado exclusivo, em meados do século 19 e [...] a própria canção nacional, a modinha, que por essa época não passa, muitas vezes, de uma simples melodia favorita, do repertório operístico, revestida de texto poético nacional. (AZEVEDO, 1956, p. 59).

Por outro lado, uma plêiade de compositores populares dedicava-se ao gênero. A modinha, a princípio, tinha acompanhamento de viola, que no século 19 será suplantada pelo violão. Este, por sua vez, a partir de meados do século perderá para o piano a preferência das famílias burguesas, permanecendo como o instrumento por excelência das práticas musicais populares urbanas. 
O que há, da mencionada época (a partir de 1870) em diante, é a consciência do forte sabor nacionalizante de algumas fórmulas, que antes apenas se insinuavam e que passam a ser diligentemente procuradas, observadas e empregadas sistematicamente nas peças dançantes dos compositores populares.

Observa-se então um curioso fenômeno de divergência entre a orientação dos compositores de escola, com obras cantadas ou executadas nos salões da boa sociedade, e as desses compositores populares, autores dos sucessos da moda, cuja musa velada tinha a irresistível atração das coisas proibidas. São eles que aprofundam o caráter brasileiro da música que produzem, dedicando-se intuitiva ou conscientemente à pesquisa de modalidades rítmico-melódicas ainda não empregadas por seus antecessores; modalidades que eram simplesmente a transposição, para o domínio da música alfabetizada, que se escreve e se imprime, das peculiaridades e jeitos de cantar, tocar ou bater o ritmo, usuais entre a gente do povo, especialmente entre os negros. [...]

A canção brasileira - modinha ou lundu - marchava, então, lado a lado, com as formas mais sérias da música religiosa, dramática ou de concerto. Na realidade pouco diferia, tecnicamente ou sentimentalmente, dessa música concebida à européia. De vez em quando, elementos mais condizentes com a sensibilidade nacional introduziam-se em seus compassos; ou caracterizava-a a insistência com que empregava as mesmas fórmulas anódinas, nacionalizadas justamente em virtude de sua freqüência. (AZEVEDO, 1956, p. 137-138).

Luiz Heitor Correia de Azevedo volta a descrever a canção de arte como gênero, inserindo o conceito no contexto brasileiro:

A Canção sempre dominou a obra dos compositores brasileiros. Nos velhos tempos eles não se pejavam de escrever modinhas singelas, de sabor popular. Com Alberto Nepomuceno nasceu a canção de arte, em que as intenções sentimentais do poema se refletem no comentário musical e o acompanhamento pianístico torna-se mais complexo, deixando de ser uma simples moldura harmônica do canto para intervir diretamente na formação do ambiente sonoro sugerido pela poesia. (AZEVEDO, 1956, p. 228).

A canção de arte brasileira surge, portanto, com um compositor determinado, Alberto Nepomuceno. Ele foi o primeiro a compor canções eruditas a partir de textos em português:

Já em seu primeiro concerto, em 1895, ele apresentara quatro canções em vernáculo. Continuou levando para a música textos de grandes poetas brasileiros. E pouco a pouco foi levantando o respeitável monumento de suas canções, que continua sendo, na música brasileira, um dos mais expressivos de nossa sensibilidade e um dos mais altos, como significação universal. (AZEVEDO, 1956, p. 165).

Ainda referindo-se às canções de Nepomuceno, Luiz Heitor diz que “[...] situam-se, sem sombra de dúvida, entre o que há de melhor e de mais sentidamente brasileiro, no canto em português." (AZEVEDO, 1956, p. 165-166). 
As canções de Nepomuceno são axiais no conjunto de sua obra. Cearense que completou seus estudos de música na Itália, Alemanha e França, ele empreendeu uma verdadeira cruzada em favor do canto lírico em português. Em suas obras vocais com acompanhamento de piano, ao fundir elementos característicos da música nacional e do idioma português vertido em poesia por autores brasileiros com a linguagem musical do romantismo alemão tardio e da vanguarda francesa, Alberto Nepomuceno tornou-se o primeiro grande compositor de canções do país. 
CAPÍTULO 3 - FORMAÇÃO

Alberto Nepomuceno nasceu em Fortaleza, Ceará, em 6 de julho de 1864, mas seus anos de formação decorreram em Recife, para onde sua família se mudou em 1872. O jovem músico permaneceu na capital pernambucana até 1884 quando, após retornar a Fortaleza e ver indeferida a petição encaminhada ao Governo Imperial pela Assembléia Legislativa Cearense, onde se solicitava uma pensão para que ele pudesse dar continuidade aos seus estudos na Europa, transferiu-se para o Rio de Janeiro.

A partir de 1881, Nepomuceno desenvolve amizade com alunos e professores da Faculdade de Direito do Recife. Por essa época, florescia nessa faculdade a chamada Escola do Recife, grupo de professores e estudantes agrupados em torno da figura de Tobias Barreto (1839-1889). O grupo consistiu em um movimento cultural de cunho germanista, que abraçava, entre outros setores, a Poesia, a Filosofia, o Direito, o Folclore, a crítica literária e musical. Barreto, além de suas atividades na área do Direito e da Filosofia, dedicava-se também à crítica musical, além de gostar de cantar, acompanhando-se ao violão, e teria sido responsável pela iniciação de Nepomuceno no estudo de filosofia e do alemão. Consideramos que esse contato com Barreto tenha sido determinante para dirigir o interesse de Nepomuceno pela cultura alemã. A crítica musical de Barreto, por exemplo, faz a apologia da ópera de Wagner, cuja estética mais tarde viria a ser a grande inspiração para o grupo de compositores e críticos musicais de que Nepomuceno fez parte. (VERMES, 1996, p. 23).

Essa vinculação de Nepomuceno à Escola do Recife ilumina a formação ideológica do compositor, as idéias que nortearam seus esforços para criar uma música brasileira.

Tobias Barreto e seu grupo dedicaram-se com especial afinco à observação e ao estudo da realidade brasileira, e a refletir sobre as questões por ela suscitadas. Essa reflexão filosófica levou alunos e professores a assumirem uma postura crítica em relação às correntes de pensamento predominantes no Império. Eles então se voltaram para as idéias novas que surgiam na Europa em busca de ferramentas que lhes permitissem atuar criticamente nessa nova visão da realidade brasileira que vislumbravam. Avelino Romero Pereira expõe as idéias defendidas por um dos mais destacados representantes da Escola do Recife, Sílvio Romero:

Na virada do século XIX para o XX, diversos intelectuais, dentre os quais destaco o sergipano Sílvio Romero (1851-1914), empreenderam uma viagem rumo à realidade brasileira, em busca de traços generalizáveis, sobre os quais pudessem elaborar fórmulas explicativas do Brasil, sintetizadas na afirmação do "caráter nacional brasileiro". Baseando-se no romantismo germânico e nas correntes evolucionistas e racistas em voga na Europa, esses estudos visavam solucionar, no plano intelectual, a problemática integração do negro e do imigrante na sociedade brasileira, 
revelando tensões e conflitos sociais e raciais, que marcaram o fim das relações escravistas e a expansão do capitalismo no Brasil. Nessa linha, num viés simultaneamente científico e ideológico, acabaram formulando uma noção de identidade nacional, que procurava indicar o lugar do Brasil entre as "nações civilizadas", "brancas" e "modernas" da Europa.

Sílvio Romero escolheu como objeto de estudo a produção literária do Brasil, publicando, em 1888, a sua História da literatura brasileira, cuja segunda edição veio a lume em 1902. Partindo do evolucionismo de Herbert Spencer e do romantismo de Johann Gottfried Herder, propôs que se procedesse à coleta e ao estudo dos documentos - "costumes e tendências populares" - que levassem à identificação do "espírito nacional" - o Volksgeist de Herder. Ao defender um programa de investigação sobre as tradições populares do Brasil, queixava-se de que os documentos não se achassem "coligidos, nem utilizados". E concluía, proclamando: "Nós desconhecemo-nos a nós mesmos". Para o sergipano, a identificação do espírito nacional era a chave que levaria a explicar tanto a literatura brasileira quanto o atraso do Brasil em relação ao modelo civilizado europeu. Esta busca dava continuidade à preocupação com o folclore brasileiro, já denotada em obras anteriores. (PEREIRA, 2007, p. 25-26).

Essa vinculação à Escola do Recife lança uma luz esclarecedora ao epíteto "Schubert brasileiro" já aplicado a Nepomuceno. Com cerca de 600 canções, o compositor vienense praticamente inventou o lied enquanto gênero, colocando música na nova poesia surgida com o movimento de renovação capitaneado por Goethe e que tinha na canção popular sua fonte principal. O movimento romântico germânico era essencialmente um movimento nacionalista, e as idéias e pesquisas de Herder são um de seus mais importantes fundamentos. Quando analisamos o cancioneiro de Nepomuceno, fica claro que o cearense procurou reproduzir intencionalmente no Brasil o processo que permitiu o surgimento do lied e seu florescimento com Schubert.

Dois vetores norteiam a criação de uma música brasileira a que se propôs Nepomuceno: um é a língua e sua musicalidade instrínseca, sem dúvida o vetor mais importante e que determinou que a canção fosse seu laboratório, onde a música européia seria flexionada pela poesia nacional, abrasileirando-se no processo; o outro é a idéia de "raça", em que o elemento nativo, índio ou negro, sofre um processo de branqueamento ao ser adaptado à música da cultura dominante. As peças que seguem este aspecto, ou seja, que incorporam elementos folclóricos, são as que os modernistas identificaram como "nacionalistas", em que o elemento nacional é explícito. Nepomuceno tem dois exemplos logo no início da sua carreira, um de inspiração negra e outro indianista, que mostram a busca de um caminho que levasse à criação da música nacional. Uma é a Dança de Negros, apresentada pela primeira vez em Fortaleza, ao piano, em um concerto realizado em 8 de maio de 1888, portanto às vésperas da Abolição. Esta peça seria orquestrada mais tarde e inserida como quarto e último 
movimento da Série Brasileira, com o título de Batuque. O outro exemplo é o drama lírico Porangaba, baseado em um poema de seu conterrâneo Juvenal Galeno. A peça ficou inacabada, mas um documento em que o compositor traçou um plano geral da obra permite entrever uma aproximação do trabalho de Nepomuceno com as idéias de Sílvio Romero:

\footnotetext{
O que o compositor faz, casando "meio" e "raça", é descrever os dois elementos da lenda, o conquistador e o conquistado, separadamente, para, no terceiro tema, apresentar a união dos dois, a "aliança das raças", através dos seguintes aspectos: "A conquista da raça vermelha inferior realizada pela raça branca através da mulher Iracema - Tema do amor - O elemento varonil, Martim, sucumbindo, pela lei inversa, diante do feminino." (PEREIRA, 2007, p. 57).
}

Nepomuceno não voltará a utilizar de forma tão explícita como na Dança de Negros elementos do folclore, seja indígena ou afro-brasileiro, o que é uma forte indicação de que ele não considerava ser esse o caminho que conduziria à criação de uma música culta brasileira, ou ao menos de que não era ele o compositor que guiaria a música nacional por esse rumo.

Com uma importantíssima exceção, A Jangada, última composição sua e seu testamento musical, nas poucas canções em que Nepomuceno se inclina para o universo popular em busca de inspiração, é a música popular urbana que se faz ouvir. Esta era vítima de forte preconceito por parte das classes dominantes, preconceito não compartilhado por Nepomuceno e que ele tentou superar, estendendo uma ponte entre as polcas, maxixes e tangos brasileiros e a burguesia fluminense do início do século.

Em 1908, o compositor (e regente) organizou as apresentações musicais da Exposição Nacional realizada na Praia Vermelha. Nessa ocasião, corajosamente convidou Catulo da Paixão Cearense para realizar o primeiro concerto de violão apresentado por um músico popular em uma sala nobre de concertos, neste caso a do Instituto Nacional de Música (CORRÊA, 1996, p. 9). A elite republicana via no instrumento "um caso de polícia, sinônimo de vadiagem" (MACHADO, 2007, p. 87). Além disso, nesses mesmos concertos da Praia Vermelha também engajou o pianista Ernesto Nazareth em duas ocasiões (MACHADO, 2007, p. 91). É preciso dizer que tanto a música de Nazareth como a de Catulo já tinham passado por um profundo branqueamento, conservando de suas fontes étnicas originais pouco mais que os ritmos sincopados e o contraponto rítmico complexo. Luiz Tatit chama o estilo desses compositores de semi-erudito (TATIT, 2002, p. 32). 
Os elementos folclóricos e populares aparecem de forma esporádica na música de Nepomuceno. Sua grandeza está em ter fincado as raízes da música brasileira na vanguarda européia, de um lado, e, de outro, na musicalidade da língua portuguesa. O compositor Rodolfo Coelho de Souza conclui assim o prefácio à edição das canções de Nepomuceno:

\begin{abstract}
Há que se rever o papel de Nepomuceno na gênese do nacionalismo. Não foi, de modo algum, contribuição original de Nepomuceno a idéia de buscar nas fontes populares e folclóricas brasileiras material para o desenvolvimento de uma música culta brasileira. [...] Sua contribuição efetiva foi ter incorporado organicamente à música brasileira as novas linguagens da vanguarda européia: o abundante cromatismo pós-wagneriano, o gosto francês pelo modalismo exótico, a tonalidade suspensa ultra-romântica, as escalas simétricas de tons inteiros e pentatônicas. Foram esses elementos estilísticos, logo assimilados pela geração modernista e cruzados com a idéia de apropriação de fontes populares, que fizeram surgir o projeto do nacionalismo musical modernista. Mas Nepomuceno não fez essa síntese. $\mathrm{Na}$ sua obra esses elementos aparecem desconectados. Só no final da vida, em peças como a Brasiliana para piano e em A jangada, sua última canção, ele aponta nessa direção. Outros, então, já trilhavam essa senda, inclusive Villa-Lobos, que escrevera em $1917^{[6]}$ o seu Uirapuru. (NEPOMUCENO, 2004, p. 17-18).
\end{abstract}

É significativo que entre as primeiríssimas obras publicadas a guisa de balão de ensaio pelo jovem Nepomuceno figure uma canção sobre texto de poeta brasileiro. Em seguida virão os anos dedicados aos estudos na Europa e as canções em idioma estrangeiro: italianas, alemãs e francesas. A retomada da composição de canções sobre textos de poetas brasileiros, em 1894, não terá volta: a partir de então, temos somente uma peça de ocasião em francês, Aime-moi, e o ciclo Le miracle de la semence, na verdade uma cantata, encomenda do autor dos textos, José de Freitas Valle, que os assinou com o pseudônimo de Jacques d'Avray.

\footnotetext{
${ }^{6}$ Aqui Rodolfo Coelho de Souza deixou-se enganar por Villa-Lobos: o Uirapuru é de 1934, tendo sido estreado em Buenos Aires no ano seguinte, 1935 (ver COLI, 1998, p. 384-385). Em 1920, ninguém ainda trilhava essa senda. Nepomuceno a abriu.
} 
Nepomuceno publicou suas primeiras obras em 1887, dois anos após ter chegado ao Rio de Janeiro. Entre essas peças inaugurais figura uma canção, Ave Maria, sobre texto de Xavier da Silveira Junior ${ }^{7}$.

A estrutura formal de Ave Maria é um AB assimétrico em que a primeira parte é duas vezes mais extensa que a segunda. O compasso é $6 / 4$ e a melodia acompanha com simplicidade silábica a métrica dos versos; por duas vezes (c. 7 e 31) Nepomuceno responde ao meio verso que precede o último verso da estrofe interpolando um compasso de 3/4. Nos outros momentos em que isso acontece, o compositor opta por conceder valores mais longos às sílabas. Como o ritmo é pouco marcado, a irregularidade métrica é absorvida com naturalidade. Para ambientar o texto religioso, Nepomuceno opta pela melodia coral harmonizada, a exemplo dos corais de Bach, em que as palavras ditam o ritmo, assim como no estilo silábico do canto gregoriano. As paradas, quase fermatas no final de cada verso, enfatizam a opção de gênero:

EXEMPLO 3: A. Nepomuceno. Ave Maria, c. 3-6

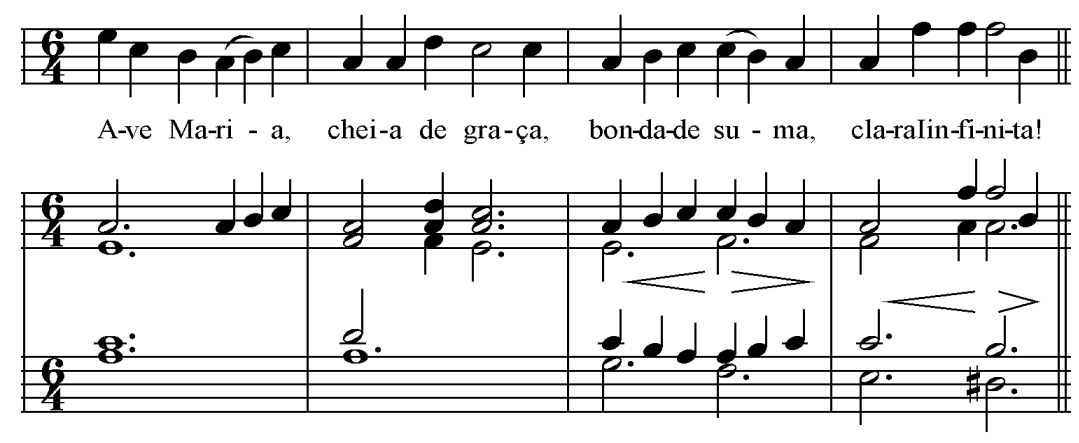

PIGNATARI, Dante (Ed.). Canções para voz e piano. São Paulo: EDUSP, 2004, p. 49.

\footnotetext{
${ }^{7}$ Segundo a Cronologia do Catálogo Geral (Corrêa. 1996, p. 11), em 1887 foram publicadas a Mazurca opus 1 para violoncelo e piano, Une fleur e a Primeira Mazurca para piano, Ave Maria para canto, e Marcha fúnebre para orquestra. Já na relação das canções, a Ave Maria aparece como indatada. Consultado, Sérgio Alvim Corrêa disse não poder afirmar que a canção em questão e a mencionada na Cronologia eram a mesma. Entretanto, a análise estilística da peça permite concluir com bastante segurança que esta Ave Maria é de fato a primeira canção composta por Nepomuceno.
} 
O acompanhamento é um coral a cinco vozes em que a voz superior dobra a melodia cantada; é quase um exercício de harmonia em que se nota a preocupação com as regras acadêmicas ${ }^{8}$, destacando-se a cuidadosa condução das vozes.

A introdução pianística apresenta o motivo melódico inicial e a tonalidade, lá maior, com uma cadência de tônica-subdominante-tônica; no retorno à tônica, esta fica suspensa em uma fermata sobre a segunda inversão do acorde:

EXEMPLO 4: A. Nepomuceno. Ave Maria, c. 1-2

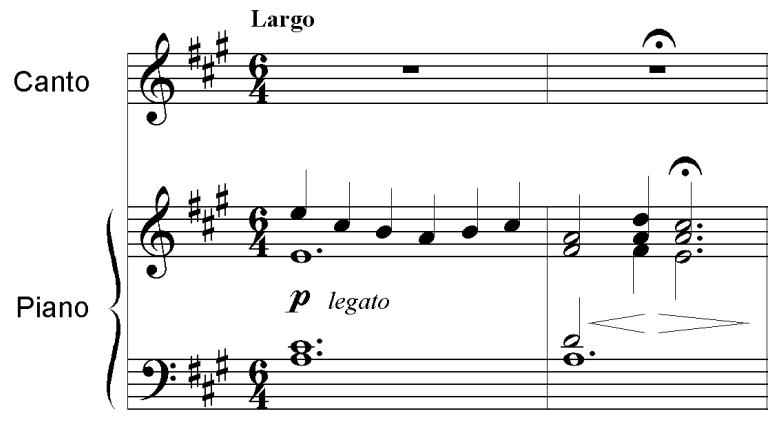

PIGNATARI, Dante (Ed.). Canções para voz e piano. São Paulo: EDUSP, 2004, p. 49.

Há ao longo de toda a peça a busca de uma atenuação da tonalidade, sendo evitada qualquer veemência em sua afirmação; trata-se de uma certa "modalização" da tonalidade que se adequa especialmente bem ao gênero escolhido, dada a proximidade com o cantochão. A cadência plagal da introdução é um recurso para tal, e os acordes de dominante quase sempre têm sua tensão rebaixada pelo acréscimo de sextas e sétimas maiores, às vezes nonas. São raras as aparições de acordes não alterados ao longo de toda a primeira parte.

No compasso 10 há uma modulação para a relativa menor, mas a coloração harmônica permanece luminosa devido à tendência harmônica favorável aos graus maiores da tonalidade (pendendo para ré maior) e aos intervalos maiores formados pelas notas acrescentadas aos acordes. A expressão se torna mais intensa a partir do compasso 19 e atinge seu ponto culminante no compasso 23, com as palavras Astro sem jaça, a partir de onde a música retorna à contenção predominante em toda a canção e também ao lá maior inicial:

\footnotetext{
${ }^{8}$ No ano anterior à publicação da Ave Maria, que coincide com sua chegada ao Rio de Janeiro, Nepomuceno estudou harmonia com Miguel Cardoso (VERMES, 1996, p. 27), o que reforça a suposição de que a canção se trate de fato de um exercício considerado suficientemente bem sucedido para merecer a publicação.
} 
EXEMPLO 5: A. Nepomuceno. Ave Maria, c. 22-26

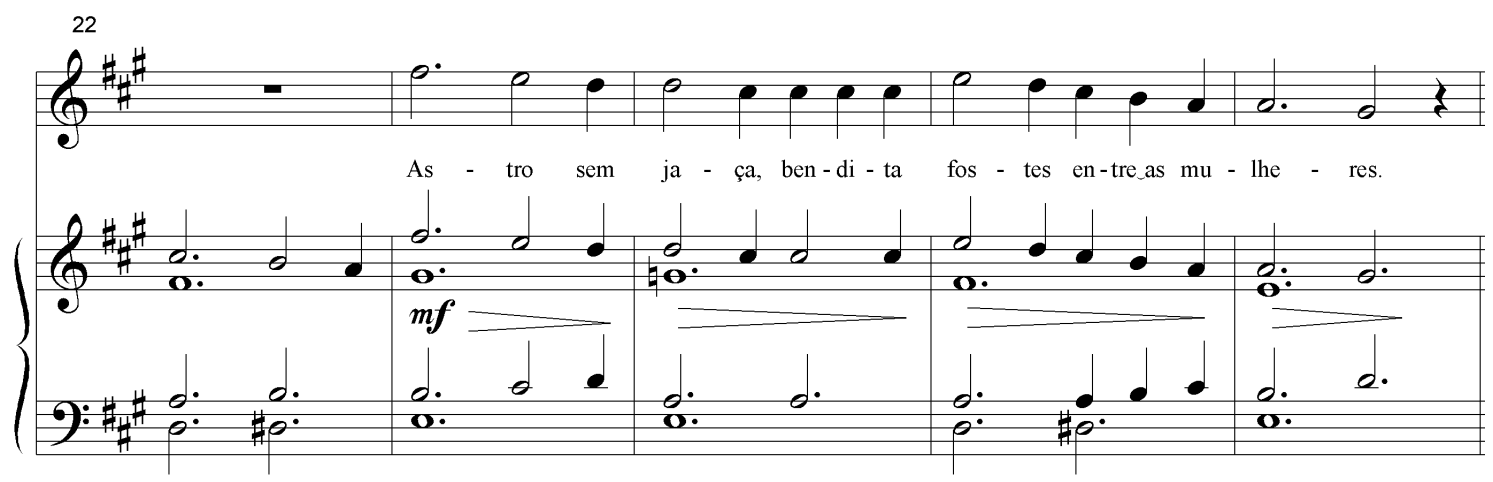

PIGNATARI, Dante (Ed.). Canções para voz e piano. São Paulo: EDUSP, 2004, p. 50.

A preparação para o ataque da nota mais aguda de toda a peça, na primeira sílaba do verso citado, é feita somente pelo piano, aumentando o impacto da entrada da voz num fá \#. Trata-se do único compasso (com exceção da breve introdução e da coda, que são idênticas) em que a voz está ausente da música.

A primeira parte conclui com uma cadência sobre as palavras Mãe de Jesus! onde, pela primeira e única vez em toda a canção, a tonalidade de lá maior é afirmada sem relutância:

EXEMPLO 6: A. Nepomuceno. Ave Maria, c. 32-36

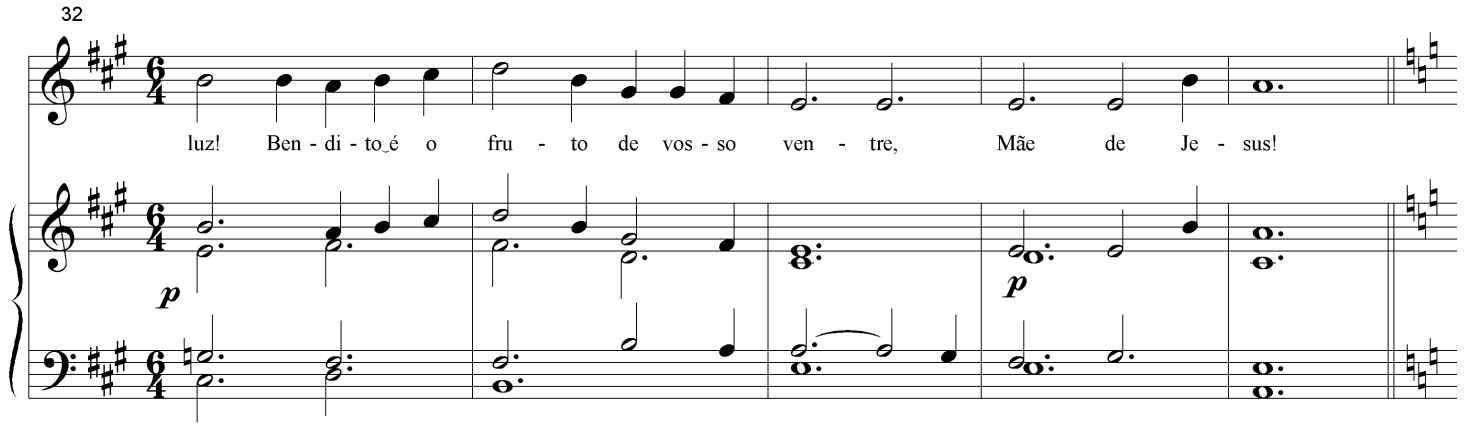

PIGNATARI, Dante (Ed.). Canções para voz e piano. São Paulo: EDUSP, 2004, p. 50.

O motivo inicial da segunda parte ${ }^{9}$, que está em lá menor, é cantado primeiro sobre o acorde de tônica na posição fundamental e em seguida repetido sobre o mesmo acorde com a sétima maior acrescentada ao baixo:

\footnotetext{
${ }^{9}$ Este motivo, curiosamente, reproduz o primeiro tema do primeiro movimento do Concerto para piano $e$ orquestra em lá menor de Edvard Grieg, composto em 1868. A coincidência é tão mais surpreendente quando sabemos das relações de Nepomuceno com o compositor norueguês, que só aconteceriam muito mais tarde, durante a estadia do cearense na Alemanha.
} 
EXEMPLO 7: A. Nepomuceno. Ave Maria, c. 37-40

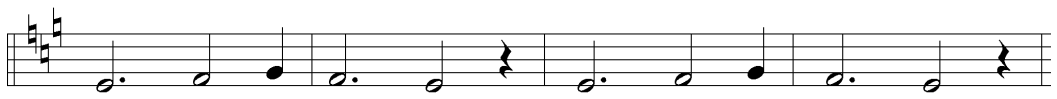

San - ta Ma - ri - a, vir - gem em Cris - to,

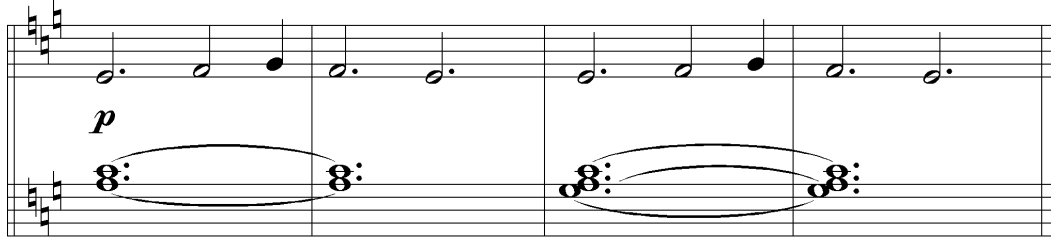

PIGNATARI, Dante (Ed.). Canções para voz e piano. São Paulo: EDUSP, 2004, p. 51.

No compasso 45 há uma mudança de fórmula de compasso, que passa a ser 2/2, coincidindo com o momento em que o poeta se refere a si mesmo, e não à Virgem. O estilo passa a ser recitativo, com notas repetidas, e o ritmo harmônico torna-se mais lento. Nos compassos 50 e 51 ocorre um momento de pintura tonal mais explícita: a palavra 'nós' é cantada sobre um acorde de mediante (dó maior) na posição fundamental, ao qual é acrescentada a sétima maior no baixo, criando a dolorosa dissonância de $2^{\mathrm{a}}$ menor sob a sílaba 'do' da palavra 'pecadores':

EXEMPLO 8: A. Nepomuceno. Ave Maria, c. 45-51

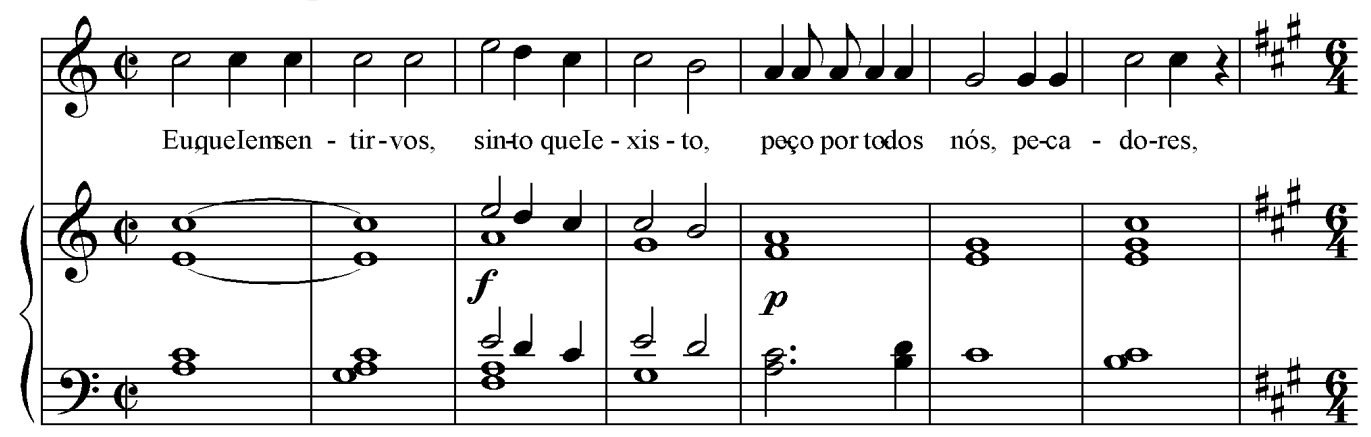

PIGNATARI, Dante (Ed.). Canções para voz e piano. São Paulo: EDUSP, 2004, p. 51.

O retorno ao lá maior inicial se dá somente no penúltimo compasso, e a peça conclui, de resto de maneira de maneira bastante inconclusiva ${ }^{10}$, com uma repetição literal da introdução instrumental inicial.

10 A segunda inversão do acorde é instável, daí a sensação de inconclusão. "O acorde 6/4 da cadência é considerado freqüentemente como uma dissonância preparada ou não preparada a ser resolvida em V. Por convenção, essa função do acorde 6/4 adquiriu tal proeminência a ponto de muitas vezes tornar-se enganoso quando aparece em outro contexto, especialmente em outro grau que não I.” (SCHOENBERG, 1969, p. 14). 
Ave Maria é de 1887. Dessa canção, e das outras peças que foram publicadas no mesmo ano, podemos deduzir qual era a bagagem musical que Nepomuceno levaria em sua viagem de estudos pela Europa, o ponto de partida, no que à linguagem musical se refere, de sua trajetória como compositor. E o que se revela é a forte influência francesa, identificável sobretudo pela análise harmônica. Essa modalização da tonalidade foi empreendida por uma escola francesa em que se destaca a figura de Gabriel Fauré, e que culminará na obra de Claude Debussy:

\begin{abstract}
Em sua tese de 1954 sobre as práticas harmônicas de Debussy e Fauré, Françoise Gervais elaborou um longo e bem pesquisado catálogo dos hábitos harmônicos característicos que podem ser encontrados na música de Fauré. Ela também chamou a atenção para o Traité d'harmonie de Gustave Lefèvre, um resumo da teoria musical ensinada na Ecole Niedermeyer. Lefèvre se refere em sua introdução aos ensinamentos que ele recebeu de Pierre de Maledan, que transmitiu-lhe, assim como a Saint-Saëns, uma concepção muito flexível da harmonia derivada do Abbé Vogler, a partir de quem ela se espalhou e influenciou toda uma galáxia de compositores, incluindo Weber e Meyerbeer. De fato, Lefèvre adota explicitamente o sistema de cifras de Vogler, que não lida com os intervalos de acordo com a maneira em que estes se relacionam com as notas do baixo, mas com o grau da escala em que o acorde está colocado; isso introduz de imediato uma concepção da harmonia que é linear e modal em espírito.

$[\ldots]$

O uso que Fauré faz da modalidade tem sido amplamente discutido e a sensação geral é que há uma relação direta entre este aspecto de sua linguagem e seu treino como músico de igreja. Ele certamente tinha em Louis Niedermeyer um professor especialista que insistia em um acompanhamento estritamente modal para o cantochão e deplorava a maneira como os modos eclesiásticos estavam sendo contaminados pelo sistema tonal; e nós, talvez, tenhamos um prazer levemente perverso ao observar que a obra reformadora de seu aluno foi precisamente abrir o sistema tonal para a contaminação da modalidade... (NECTOUX, 1991, p. 227-229).
\end{abstract}

Ao escolher a forma de um coral a 5 vozes para ambientar o texto de Ave Maria, Nepomuceno dá provas de ser versado também na tradição germânica, Bach neste caso. De resto, sua formação como pianista e organista não lhe permitiria ignorá-la, ao menos a que vai de Bach a Liszt. Aparentemente, o contato com Brahms e Wagner somente se deu na própria Alemanha, em sua temporada de estudos na terra de Beethoven.

Por outro lado, não é possível deixar de notar a ligação visceral que existe entre a melodia singela da Ave Maria e os cânticos populares, sacros e profanos, que certamente povoaram a infância e a adolescência de Nepomuceno. Aqui, o elemento "brasileiro" mais facilmente identificável é o balanço característico do compasso composto binário com subdivisão ternária. Quanto à melodia, o exemplo 99, Coração Santo, que compartilha com a 
Ave Maria o mesmo tipo de compasso ${ }^{11}$, lembra muito esse caráter singelo da Ave Maria quando transposto para o modo maior:

EXEMPLO 9: ANÔNIMO. Coração Santo (transposto para o modo maior)
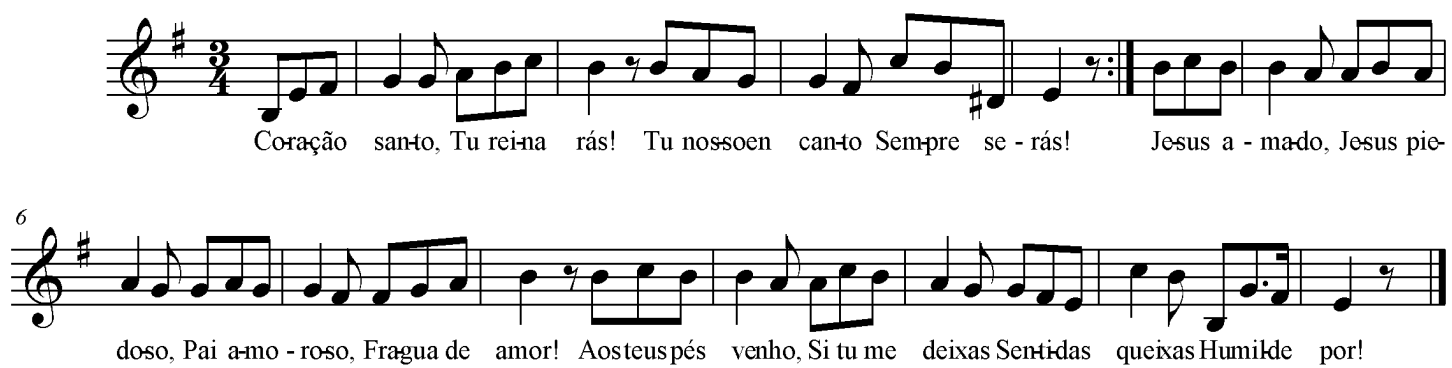

(ANDRADE, 1962, p. 103)

EXEMPLO 10: A. Nepomuceno. Ave Maria, c. 3-10
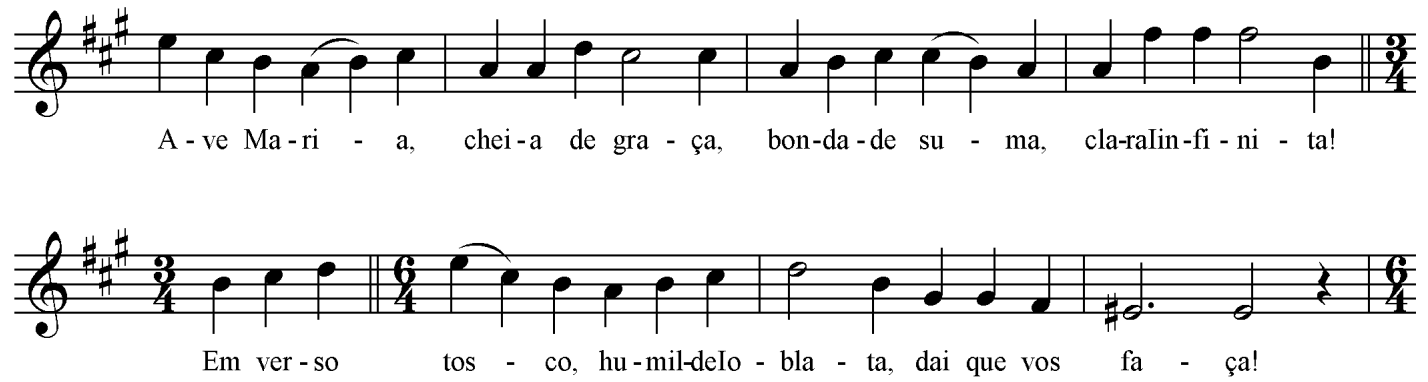

PIGNATARI, Dante (Ed.). Canções para voz e piano. São Paulo: EDUSP, 2004, p. 49.

Este mesmo balanço e essa mesma singeleza aparecem novamente na penúltima canção escrita por Nepomuceno, Canção do rio, aí sim em tom explicitamente popular:

EXEMPLO 11: A. Nepomuceno. Canção do rio, c. 3-10

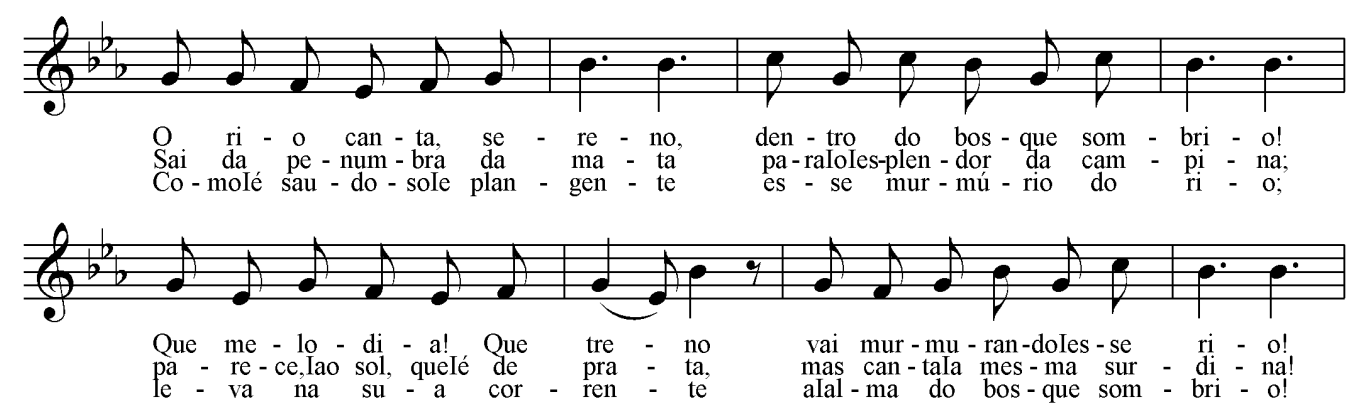

PIGNATARI, Dante (Ed.). Canções para voz e piano. São Paulo: EDUSP, 2004, p. 271.

${ }^{11}$ A indicação de compasso ternário está equivocada, é impossível cantar a melodia no compasso indicado; o correto é 6/8. Trata-se certamente de alguma desatenção, já que Mário jamais cometeria um erro tão bobo. 
O modalismo, essencial para se entender a gênese da música brasileira, é tanto francês como nordestino. Sua vertente européia está presente, em maior ou menor grau, de forma difusa, em todo o cancioneiro de Nepomuceno. Já a transmutação sofrida pelos modos gregorianos no Nordeste brasileiro somente comparece explicitamente na última canção composta por ele, A Jangada.

De resto, essa harmonia "modalizada" foi incorporada também por Villa-Lobos, especialmente via Debussy, e por seu intermédio se estende até a bossa-nova de Tom Jobim. 
Em 1888 Nepomuceno partiu para a Europa em viagem de estudos; sua primeira escala foi Roma. Ele a princípio seguiu a rota dos que o precederam (lembramos especialmente Carlos Gomes e Henrique Oswald). Talvez razões materiais o tenham guiado nesta primeira etapa, já que a viagem foi empreendida em companhia dos irmãos Bernardelli, cuja família o apoiava e colaborava no financiamento de seus estudos europeus. "Lá, matricula-se no Liceo Musicale Santa Cecilia, na classe de harmonia de Eugenio Terziani (1824-1889) e com a morte deste, prossegue os estudos com Cesare de Sanctis (1830-1915).” (VERMES, 1996, p. 30).

Do período italiano resultam quatro canções $^{12}$. Todas compartilham o dialeto harmônico de Ave Maria, especialmente pelo acréscimo da sétima maior às tríades. A que mais nos chama a atenção é sem dúvida Perchè?, de 1888, sobre texto de Aleardo Aleardi, uma obra-prima de concisão.

A canção foi estruturada com grande economia de recursos. O acompanhamento é simples: em compasso quaternário, acordes em semínimas se encadeiam sobre um baixo em oitavas que, por sua vez, move-se em mínimas ou se detém em semibreves. A introdução instrumental começa com uma cadência I6-V4/3-I7, configurando uma harmonia em que a tonalidade é atenuada por acordes alterados, neste caso pela sétima maior acrescentada ao acorde de si bemol maior que confirma a tonalidade da canção no segundo compasso. Já nesta primeira cadência surge o intervalo de semitom que, como veremos, ocorre com insistência crescente e vai se revelando elemento estrutural fundamental na formação do significado da canção. Aqui ele é descendente, e ocorre na passagem do acorde de dominante para o de tônica no primeiro tempo do segundo compasso ( $\mathrm{mi}$ bemol - ré), perdurando ainda harmonicamente, invertido, na sétima maior que o lá acrescentado ao acorde de tônica forma com o baixo. Os dois compassos seguintes formam outro movimento cadencial que leva ao segundo grau da tonalidade, também com a sétima maior acrescentada. $\mathrm{O}$ movimento melódico descrito acima, de um semitom, ocorre exatamente na mesma voz e no mesmo ponto (quarto tempo do c. 3 - primeiro tempo do c. 4), agora cobrindo o intervalo de um tom,

\footnotetext{
${ }^{12}$ Uma delas, Rispondi, sobre texto de Aleardo Aleardi, o mesmo poeta de Perchè, está extraviada. O neto do compositor e autor do Catálogo Geral, Sérgio Alvim Corrêa, lembra-se do manuscrito e até mesmo de havê-la copiado, mas não nos foi possível encontrar nem o original, nem a cópia.
} 
levando a harmonia de VI4/3 para II7. Este movimento de um tom descendente para II e que dura apenas um tempo, em uma perspectiva ampliada contrapõe-se a outro de um tom ascendente nos acordes da mão direita do acompanhamento, entre a oitava de fá dos dois primeiros compassos e a de sol dos dois compassos seguintes:

EXEMPLO 12: A. Nepomuceno. Perchè?, c. 1-5

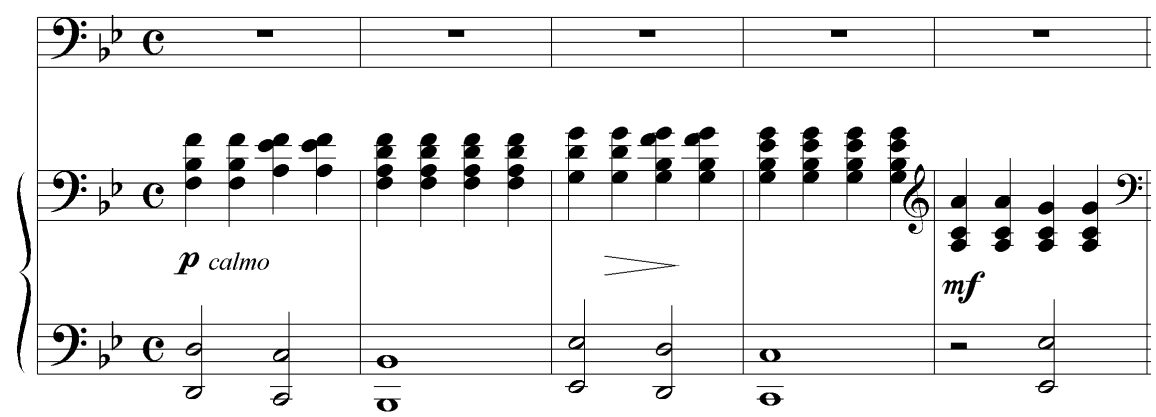

PIGNATARI, Dante (Ed.). Canções para voz e piano. São Paulo: EDUSP, 2004, p. 52.

Estes movimentos diatônicos, predominantes, formam um dos pólos estruturais da canção, que na verdade constitui seu significado com base no jogo de movimentos cromáticos e diatônicos, que ocorrem no baixo, nos acordes da mão direita do piano (internamente e também se tomamos esses acordes como uma única linha) e na parte cantada.

No compasso 5 há uma mudança agógica no baixo, que é omitido na primeira metade do compasso e retoma o movimento feito no segundo compasso, em anacruse e delineando um gesto igualmente descendente e diatônico, agora mais amplo, de quatro compassos. A voz entra no compasso seguinte, também em anacruse, sobre uma cadência que reproduz a que leva do compasso 1 ao 2 e que confirma a tonalidade, V4/3 - I7. Permanecendo sobre a nota fá por dois compassos e meio, a voz se eleva um tom no compasso 9, permanecendo sobre o sol por dois compassos para então, num gesto diatônico ascendente, elevar-se até si natural que, sendo a sensível de II (o gesto sol - lá - si bequadro está sobre V do II) e tendo sido atingido a partir de fá, com o qual forma um trítono, produz um efeito de suspensão e formula de forma convincente a interrogação do texto: 
EXEMPLO 13: A. Nepomuceno. Perchè?, c. 6-11

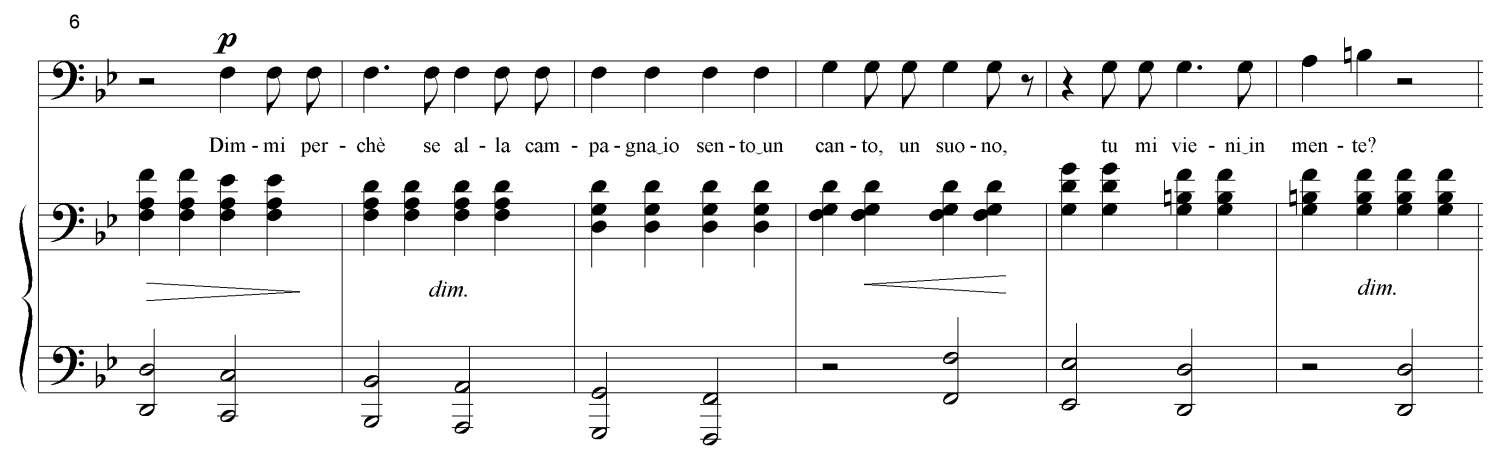

PIGNATARI, Dante (Ed.). Canções para voz e piano. São Paulo: EDUSP, 2004, p. 52.

A segunda estrofe (nesta canção, a uma estrofe poética corresponde uma frase musical) retoma a recitação sobre uma nota só um tom abaixo em relação à frase inicial, enquanto os acordes da mão direita têm a fundamental um tom acima. Nesta segunda frase as sílabas são comprimidas em um espaço menor, o que gera uma aceleração. O meio compasso suprimido corresponde exatamente à anacruse da primeira frase, o que confere a esta maior ênfase e impulso para o gesto seguinte: em contraste com o gradual movimento diatônico ascendente da primeira frase, a voz vai diretamente das notas repetidas para um salto de sexta maior. Este primeiro ponto culminante, um dó, meio tom mais agudo que a nota que encerra a primeira frase, ilustra a palavra firmamento, de onde desce lentamente em cadência de tônicadominante que é uma ampliação da cadência de abertura da peça. Mas ao chegar ao mi bemol de onde partira, sobre V4/3, a frase se flexiona ascendentemente por graus cromáticos sobre a palavra presente, enquanto a harmonia começa a modular para a supertônica, dó maior:

EXEMPLO 14: A. Nepomuceno. Perchè?, c. 13-17

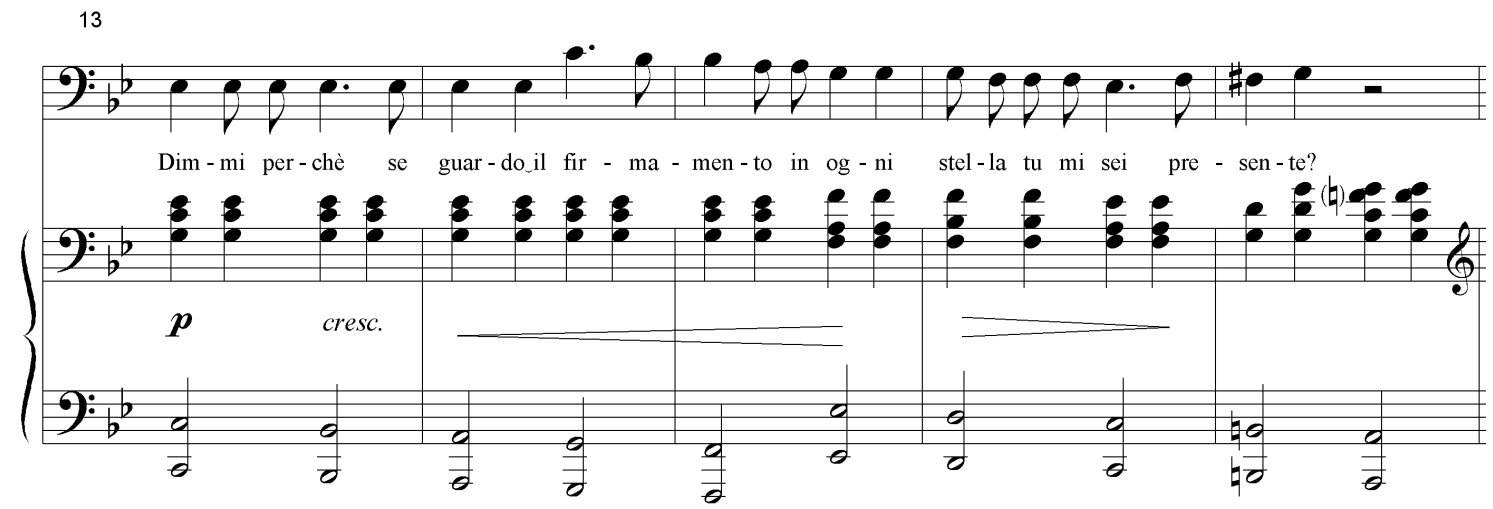

PIGNATARI, Dante (Ed.). Canções para voz e piano. São Paulo: EDUSP, 2004, p. 52-53. 
Há uma nova compressão e aceleração da frase anterior: meio compasso de anacruse sobre sol, e novo salto de sexta maior, atingindo outro ponto culminante, um mi, agora em dó maior, sem notas acrescentadas. Esta maior nitidez da tonalidade reforça o momento de grande intensidade de expressão. A frase então retorna, mas ao chegar à nota lá abaixo, onde se detém ao completar metade do percurso, nela insiste, com um tempo de anacruse e todo um compasso de colcheias repetidas, para lançar-se a novo salto de sexta, agora menor, atingindo a nota mais aguda de toda a peça, um fá, uma oitava acima do início da melodia cantada e um semitom mais agudo que o ponto culminante anterior, reproduzindo assim nesta terceira fraseestrofe a relação intervalar entre os pontos culminantes da primeira parte da canção:

EXEMPLO 15: A. Nepomuceno. Perchè?, c. 18-23

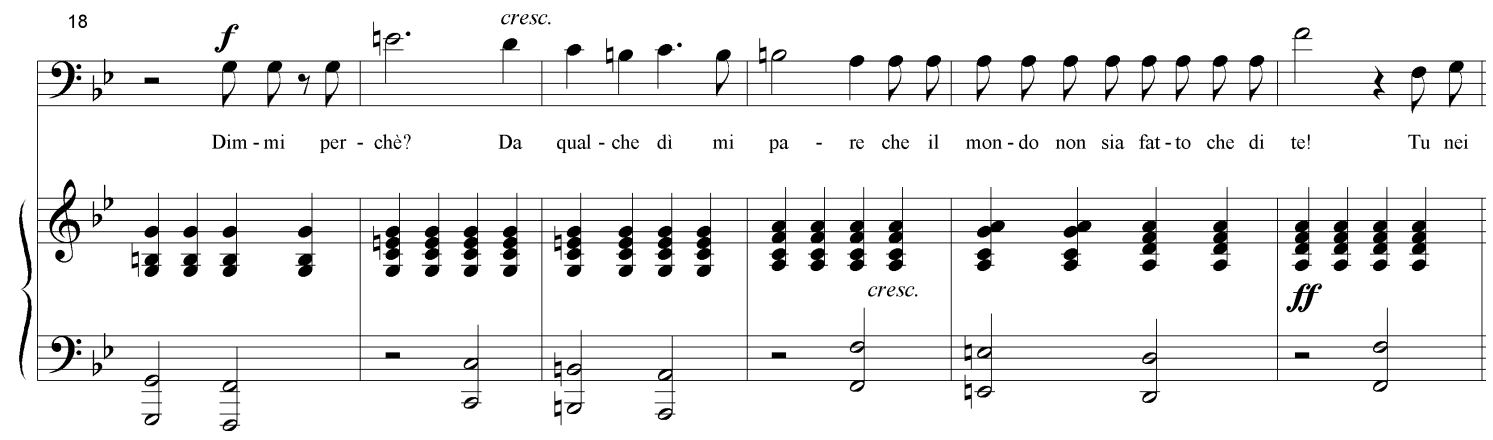

PIGNATARI, Dante (Ed.). Canções para voz e piano. São Paulo: EDUSP, 2004, p. 53.

A estrofe final confere significado ao intervalo melódico cromático. O movimento ascendente é primeiro diatônico, desenhando em seguida um intervalo de meio tom, e então dois, em que a presença da amada, identificada anteriormente pelo intervalo cromático ascendente sobre a palavra presente, se generaliza na paisagem (tu nei fior', tu nel ciel, tu nel mare) assim como o intervalo cromático ascendente invade a linha melódica:

EXEMPLO 16: A. Nepomuceno. Perchè?, c. 23-26

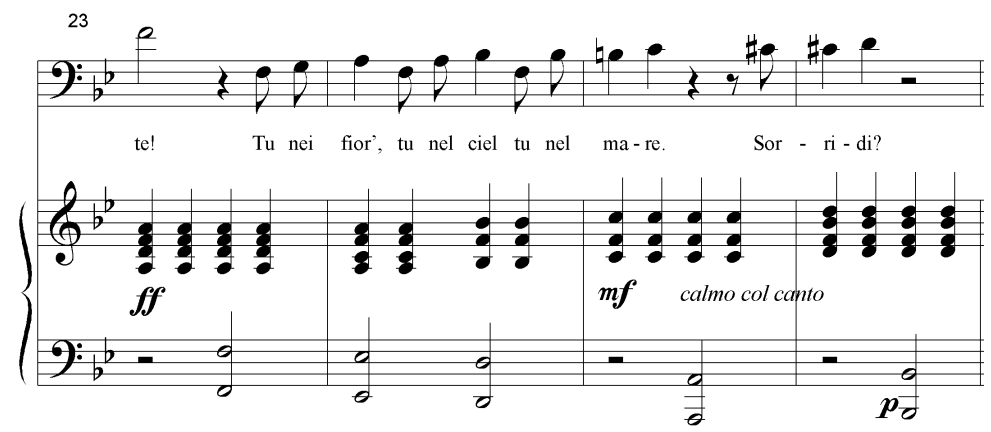

PIGNATARI, Dante (Ed.). Canções para voz e piano. São Paulo: EDUSP, 2004, p. 53. 
Uma pausa determina um momento de reação, uma mudança de atitude por parte do narrador, já que o que se segue é agora uma constatação, apesar do ponto de interrogação: Sorridi?, cantada sobre uma reiteração intensificada do intervalo de meio tom, que novamente ocorre tanto melódica como harmonicamente. A passagem para a coda (Lento) é feita por novo movimento cromático ascendente, desta vez nas oitavas do baixo, reflexo do cromatismo da frase recém cantada. O último verso é recitado sobre o fá com que a voz iniciara a canção, sobre uma harmonia que reproduz de forma ampliada a cadência introdutória do primeiro compasso, concluindo com um movimento ascendente final de meio tom que, no primeiro compasso, é descendente (mi bemol no acorde de V7 para ré de I7). No final, é de sensível para tônica, levando ao acorde de tônica, finalmente e pela primeira vez sem notas acrescentadas e na posição fundamental:

EXEMPLO 17: A. Nepomuceno. Perchè?, c. 27-31

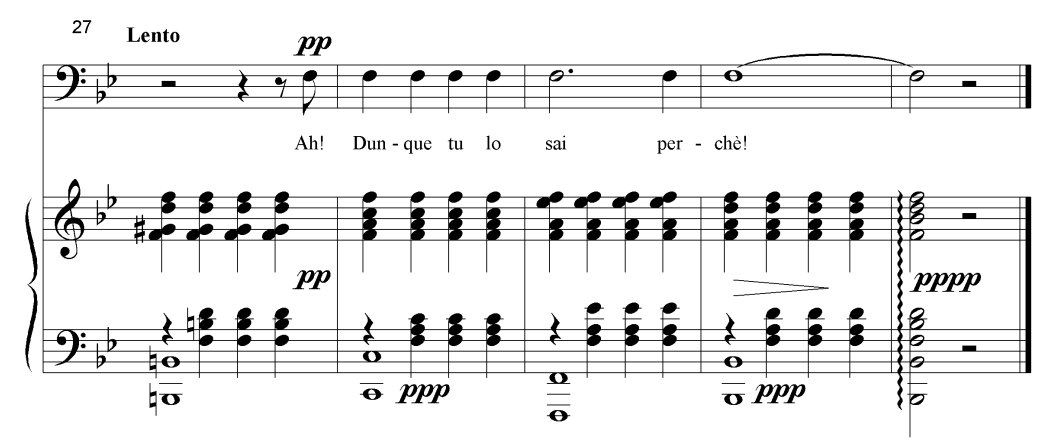

PIGNATARI, Dante (Ed.). Canções para voz e piano. São Paulo: EDUSP, 2004, p. 53.

A três primeiras frases-estrofes que compõem a canção têm todas 5 compassos. A pausa que as separa vai diminuindo progressivamente, de seis tempos da primeira para a segunda a apenas um da terceira para a quarta. Esta estrofe final se espalha por oito compassos, incluídos os quase seis tempos de pausa que separam a primeira parte do último verso que compõe a coda. Metricamente, as frases vão se comprimindo até o ponto culminante, onde também se constitui musicalmente o significado do texto. A coda é na verdade uma descompressão que reequilibra metricamente a peça como um todo.

A relação dos deslocamentos da parte cantada e dos acordes do acompanhamento é de grande equilíbrio, conferindo estabilidade à estrutura da canção: A voz parte de fá e tem seu ponto culminante uma oitava acima (c. 23), para terminar novamente no fá inicial. Já os acordes vão se deslocando a partir do mesmo fá, se considerarmos a nota fundamental, 
afastando-se gradualmente das oitavas do baixo e ascendendo por graus diatônicos até percorrer o intervalo de oitava, o mesmo percorrido pela voz.

O texto é uma série de perguntas, e todas as frases cantadas terminam com um gesto ascendente, com exceção da última que, como vimos, é uma recitação sobre a nota fá; aqui o movimento ascendente ocorre no acorde do acompanhamento, de lá para si bemol. O mesmo intervalo de semitom que faz as perguntas contém em si, implícita, a resposta, que é a própria presença da amada, também sempre implícita, na paisagem, e portanto nos pensamentos do narrador.

Nas canções italianas, assim como na Ave Maria, Nepomuceno se vale principalmente de recursos melódicos para interrelacionar música e poesia, mas a fluência harmônica adquirida na Itália se faz notar. Chama a atenção também a adaptação da linguagem musical ao idioma dos textos que ambienta: particularmente em Perchè? e Un soneto del Dante, Nepomuceno escreve música italiana. Esta capacidade camaleônica de absorção de estilos nacionais se repete nas canções alemãs, e novamente nas francesas.

É deste período italiano de Nepomuceno sua única canção com instrumento melódico obligato, no caso o violino, que ambienta um soneto de Dante Alighieri. O recurso da sétima maior acrescentada aos acordes é usado aqui com maior economia e também com maior variedade, estando a nota acrescentada muitas vezes apenas na parte da voz ou do violino. Ao contrário da Ave Maria, a tonalidade é afirmada desde o início e ao longo de toda a peça. Aproximam este Soneto da Ave Maria a simplicidade e o caráter luminoso da harmonia, igualmente adequados ao texto, que exalta a honestidade, beleza e humildade de Beatriz quando o poeta a saúda, comparando-a a um milagre do céu. Por outro lado, os gestos melódicos amplos, a métrica generosa e a simplicidade do acompanhamento (acordes em semínimas sobre baixo em oitavas) associam Un Soneto e Perchè? no que ambas têm de eminentemente italiano: 
EXEMPLO 18: A. Nepomuceno. Un Soneto del Dante, c. 1-11
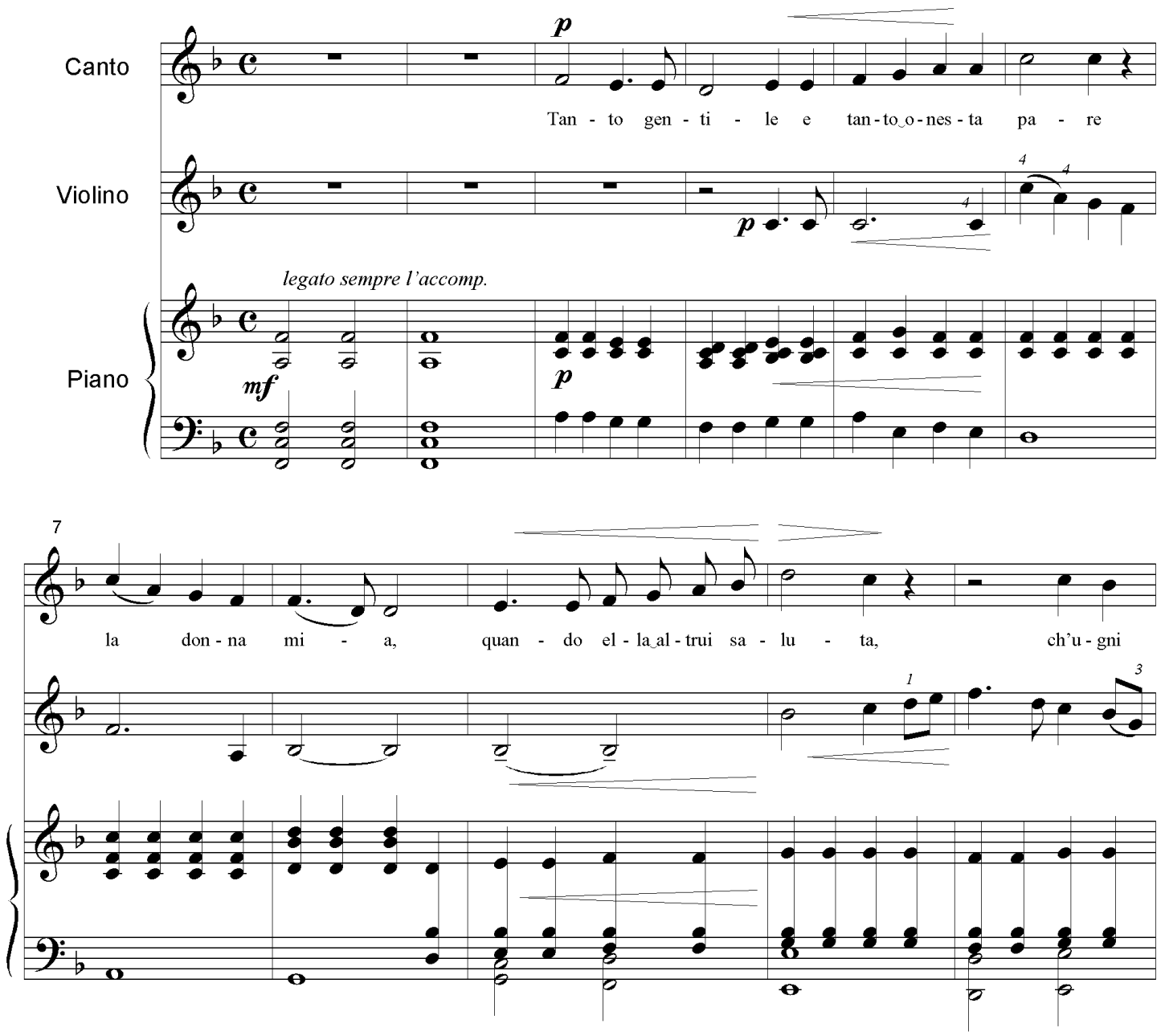

PIGNATARI, Dante (Ed.). Canções para voz e piano. São Paulo: EDUSP, 2004, p. 54.

A estrutura da peça apoia-se essencialmente no jogo entre os deslocamentos das partes melódicas (voz e violino) pelos respectivos âmbitos abarcados (décima e décima-terceira respectivamente), ora por graus diatônicos, ora por saltos de terça, quarta ou oitava. Destacase a utilização do recurso de compressão ou dilatação do texto para acelerar ou retardar o movimento melódico sem alterar o andamento do acompanhamento. Assim como em Perchè?, a compressão das sílabas quase sempre serve para lançar a melodia em um salto ascendente. Outra característica comum às duas canções é a conclusão, feita aqui pelo violino, que reproduz uma oitava acima a melodia vocal do primeiro verso da canção. O piano conclui com tranquilos acordes de tônica na posição fundamental, em semínimas, reproduzindo também os acordes iniciais da peça. Toda a coda é uma reminiscência do início da canção: 
EXEMPLO 19: A. Nepomuceno. Un Soneto del Dante, c. 43-52

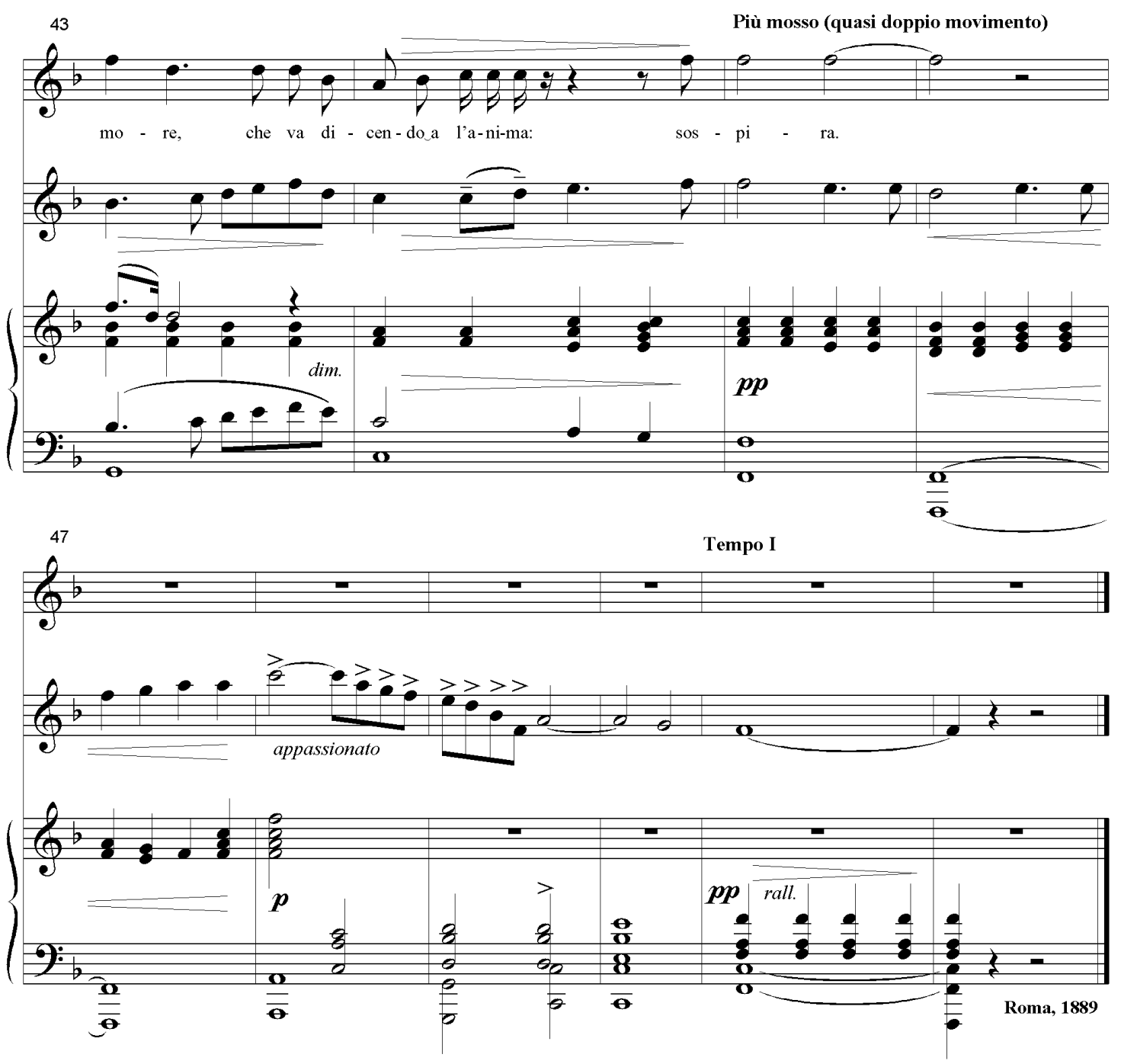

PIGNATARI, Dante (Ed.). Canções para voz e piano. São Paulo: EDUSP, 2004, p. 57.

A última canção produzida na Itália é Serenata di un moro, adaptação de uma versão em italiano de Ständchen eines Mauren, de Heine. A peça é um estudo de estilo em que Nepomuceno procura criar um ambiente "oriental", mourisco neste caso, por meio da modalização e da ornamentação da melodia. O poema tem quatro estrofes de quatro versos cada. Na primeira parte, 35 compassos que se encarregam da primeira estrofe do poema, Nepomuceno aplica duas métricas diferentes, uma para as frases cantadas, que duram quatro compassos, e outra para a introdução e os interlúdios instrumentais, de métrica irregular. A introdução instrumental se estende por 10 compassos $(4+3+3)$ e apresenta a tonalidade, ré menor, com uma textura estruturada em três camadas de som ${ }^{13}$ diferenciadas com nitidez: um baixo harmônico que se move em mínimas ou se imobiliza em pedais de semibreves; uma

\footnotetext{
${ }^{13}$ A estrutura bipolar barroca “...foi substituída por um conceito de espaço musical estratificado, de maneira geral, em três camadas, grosso modo aguda, média e grave, sendo que qualquer uma delas poderia desempenhar as funções de melodia ou harmonia...”. (BORROFF, Edith: The Music of the Baroque, in PIGNATARI, 1992, p. 11).
} 
melodia que se desloca em movimento contrário em relação ao baixo (como mandam as regras do contraponto acadêmico) mas em contratempo, já que as notas da melodia são sempre atacadas na segunda colcheia de cada tempo; e um recheio harmônico constituído de terças em staccato que, ao lembrar cordas dedilhadas, cria o ambiente melancólico e o caráter de serenata desejados (a indicação de caráter é "com melancolia”):

EXEMPLO 20: A. Nepomuceno. Serenata di un moro, c. 1-10
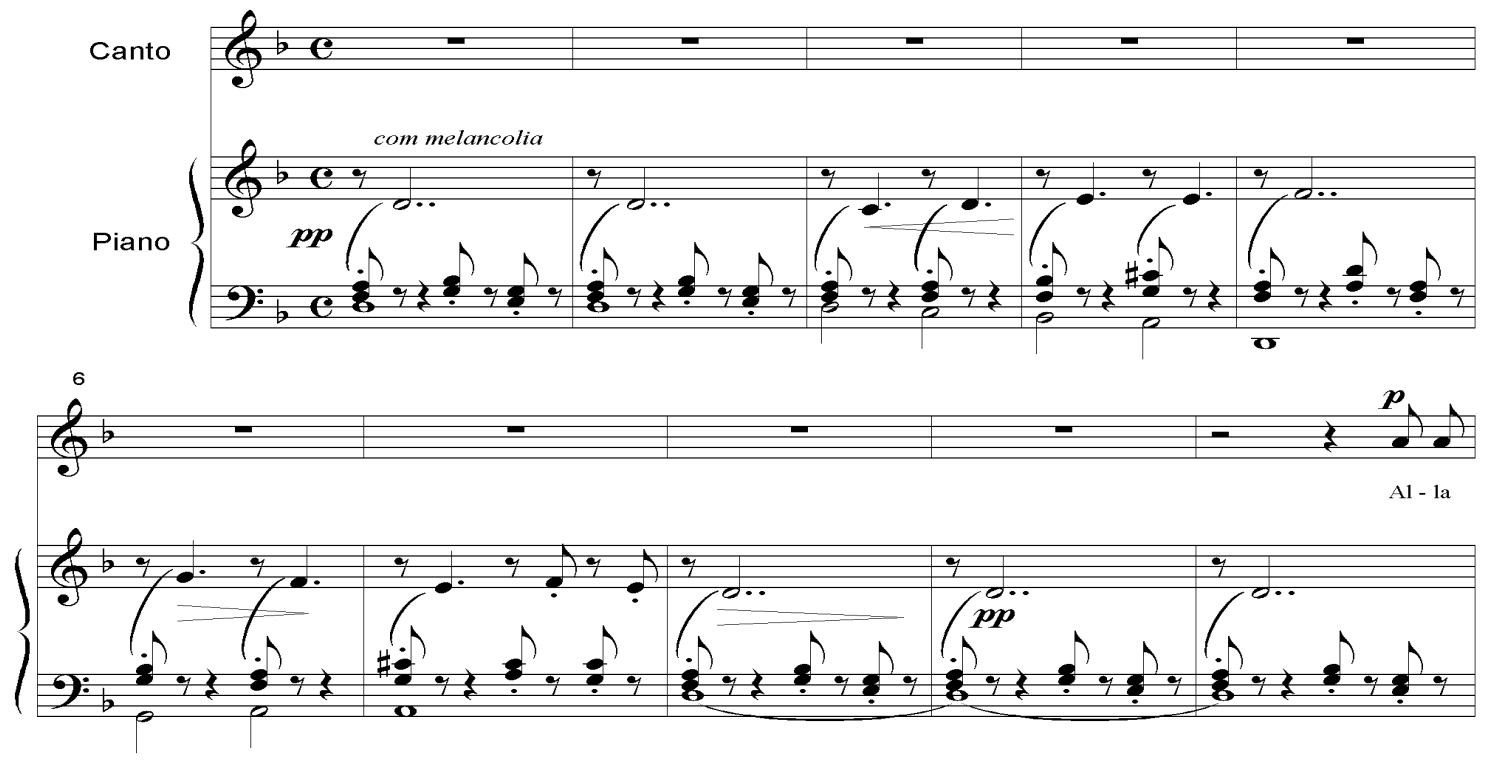

PIGNATARI, Dante (Ed.). Canções para voz e piano. São Paulo: EDUSP, 2004, p. 58.

Como na Ave Maria, a cadência introdutória é plagal; ocorre aqui novamente a modalização da tonalidade, que se evidencia agora sobretudo no componente melódico, que se alterna entre instrumento e voz; a cada intervenção desta o acompanhamento se imobiliza, melodicamente falando, retomando a função melódica quando a voz cessa. $\quad \mathrm{Na}$ primeira frase cantada, que reproduz a ascenção gradual até uma quarta acima do ponto de partida delineada pela introdução instrumental, a sensível é evitada por duas vezes, de maneiras distintas: primeiro, saltando de si bemol diretamente para ré, e na segunda parte da frase, pela ascenção cromática dó-dó\#-ré, retirando da nota dó\# o caráter de sensível e introduzindo a segunda aumentada si bemol - dó\# da escala menor harmônica que dará à peça um ar "oriental"14:

\footnotetext{
14 “A assim chamada mélodie oriental é geralmente construída sobre os modos medievais, principalmente o primeiro, sétimo e nono. A segunda aumentada, proibida no contraponto estrito, pode, de maneira similar, sugerir o exotismo." (NOSKE, 1970, p. 313). Nepomuceno procede de maneira sutil: a segunda aumentada nunca aparece de forma explícita, melodicamente, mas como sugestão, dissolvida no contexto harmônico.
} 
EXEMPLO 21: A. Nepomuceno. Serenata di un moro, c. 10-14

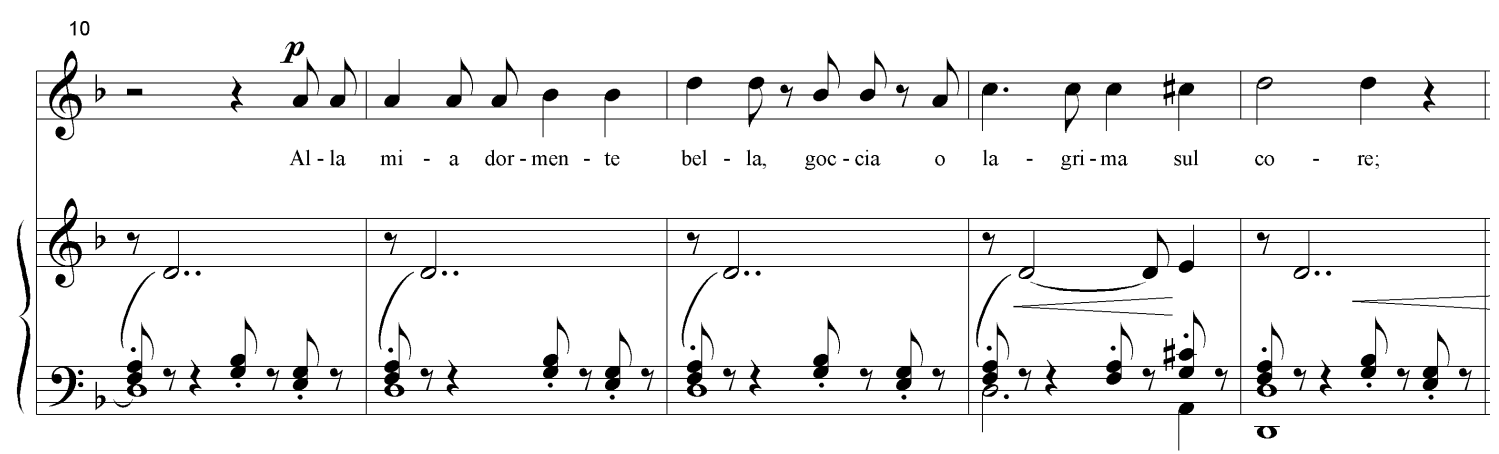

PIGNATARI, Dante (Ed.). Canções para voz e piano. São Paulo: EDUSP, 2004, p. 58.

A segunda parte da canção, em sol menor, é constituída de uma única linha melódica de forte caráter modal; não ocorre nenhum fá \# em toda a seção, nem mesmo na última fermata, sobre a nota lá, quando a harmonia se flexiona para retornar a ré menor, pois o acorde de dominante do acompanhamento omite a terça, numa combinação tipicamente medieval de quartas e quintas. O piano dobra a voz, contribuindo com acordes somente nos pontos de detenção do movimento melódico assinalados pelas fermatas. Nesta segunda parte há uma condensação do tempo, uma ampliação do âmbito melódico e uma intensificação da expressão. Não há interlúdios instrumentais, e à razão de dois compassos por verso, dezoito compassos dão conta de duas estrofes do poema:

EXEMPLO 22: A. Nepomuceno. Serenata di un moro, c. 36-41

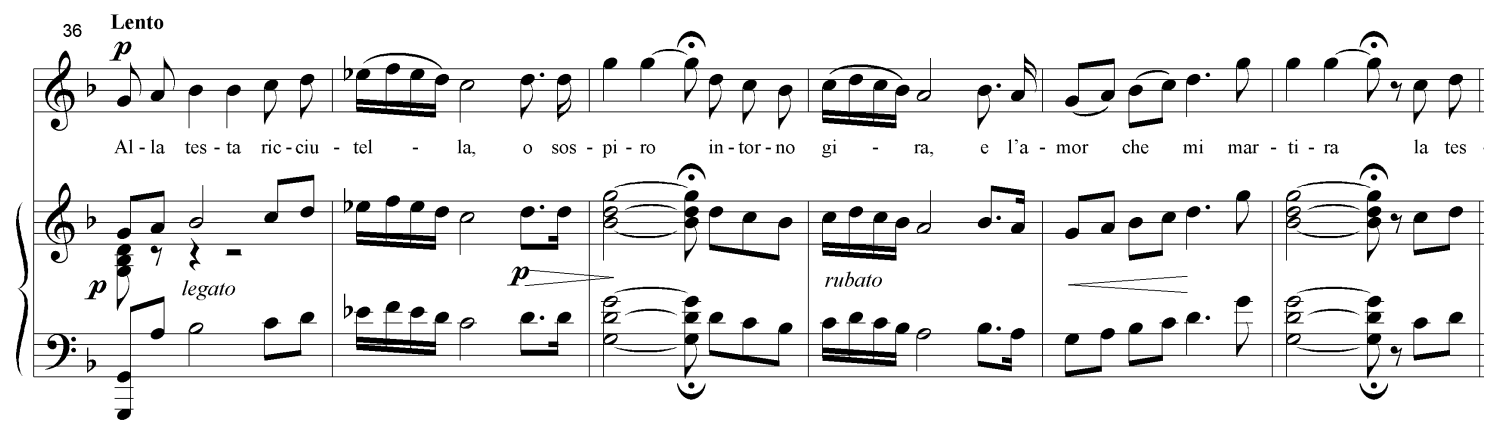

PIGNATARI, Dante (Ed.). Canções para voz e piano. São Paulo: EDUSP, 2004, p. 60.

O caráter oriental é preservado nesta segunda parte, agora com um recurso melódico: o ornamento em semicolcheias, quase um cacoete da música espanhola contemporânea de Nepomuceno e intimamente associado ao caráter "mourisco" da música inspirada no folclore andaluz. Citamos um exemplo escolhido ao acaso: 
EXEMPLO 23: E. Granados. Danzas Españolas: Villanesca, c. 83-90
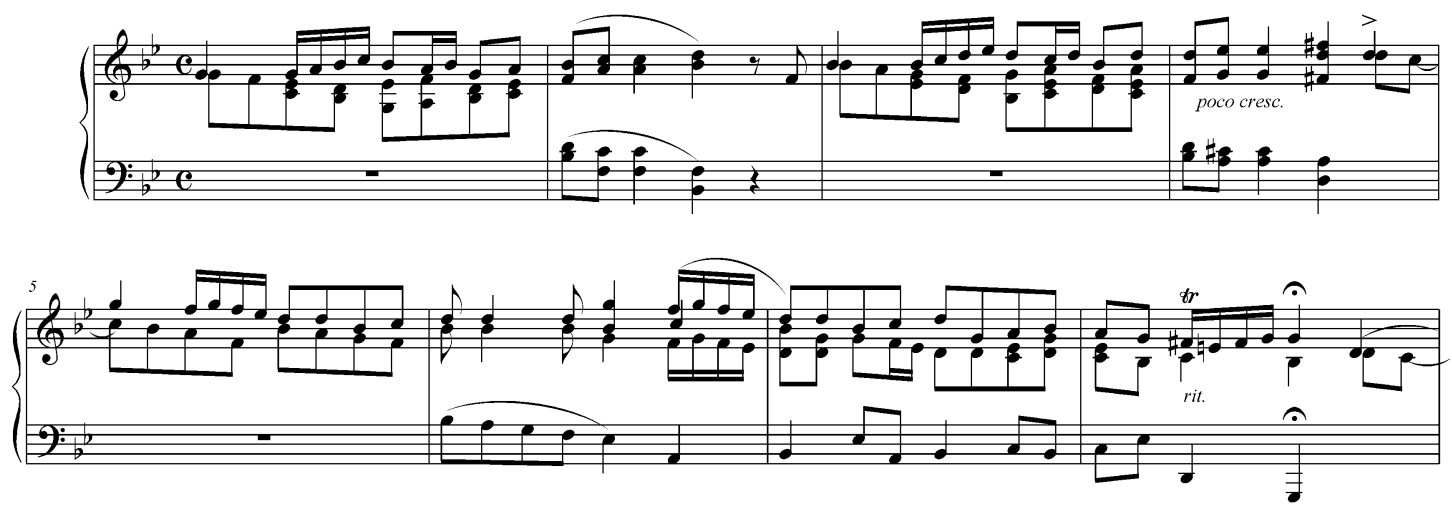

GRANADOS, Enrique (Ed.).Goyescas, Spanish Dances and other works. New York: Dover,1987, p. 84.

Embora os recursos de pintura tonal sejam utilizados com parcimônia, Nepomuceno não perde a oportunidade de destacar alguma palavra do texto e ilustrá-la musicalmente quando a oportunidade se apresenta. Um exemplo na primeira parte da canção está logo no primeiro verso, em que a palavra goccia (gota) é cantada com duas colcheias repetidas executadas non legato:

EXEMPLO 24: A. Nepomuceno. Serenata di un moro, c. 12

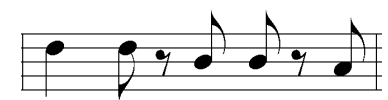

bel - la, goc-cia o

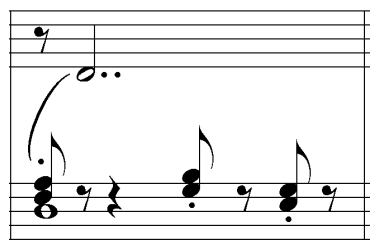

PIGNATARI, Dante (Ed.). Canções para voz e piano. São Paulo: EDUSP, 2004, p. 58.

Na segunda parte, o ornamento em semicolcheias citado acima, que forma um desenho semicircular, incide primeiro sobre a palavra riccintella (encaracolada), e em seguida sobre gira: 
EXEMPLO 25: A. Nepomuceno. Serenata di un moro, c. 38-39

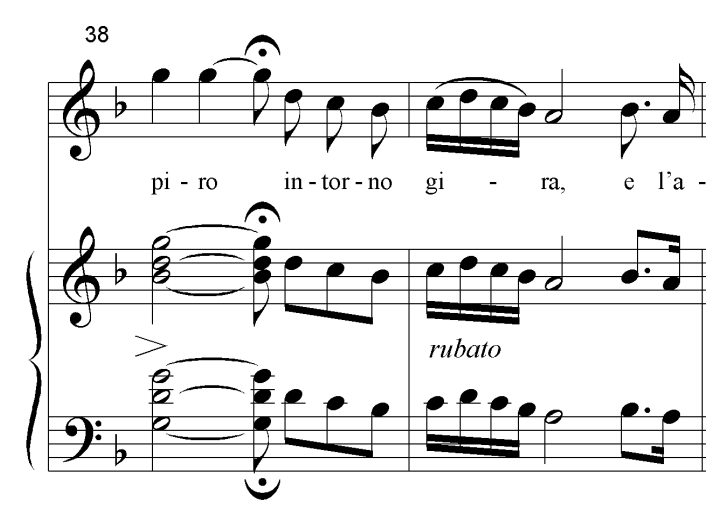

PIGNATARI, Dante (Ed.). Canções para voz e piano. São Paulo: EDUSP, 2004, p. 50. 
CAPÍTULO 6 - AS CANÇÕES ALEMÃS

Em Agosto de 1890, Nepomuceno deixa Roma. Transfere-se para Berlim e ingressa na Academia Meister Schulle, onde estuda composição com Heinrich von Herzogenberg, que se casara com uma ex-aluna e grande amiga de Brahms (BECKER, 1980, p. 157). Isso se reflete nas duas primeiras canções que resultam dessa temporada de estudos na Alemanha, de inspiração claramente brahmsiana.

Der wunde Ritter ( $O$ cavaleiro ferido) ambienta novamente um texto de Heine, agora no alemão original. Aqui não encontramos mais a harmonia de notas acrescentadas das canções anteriores. A solidez e clareza da linguagem harmônica e o tratamento diatônico dado ao material melódico são brahmsianos. Não só isso, também a forma segue os preceitos defendidos por Brahms em relação à composição de canções ${ }^{15}$ :

EXEMPLO 26: A. Nepomuceno. Der wunde Ritter, c. 1-6

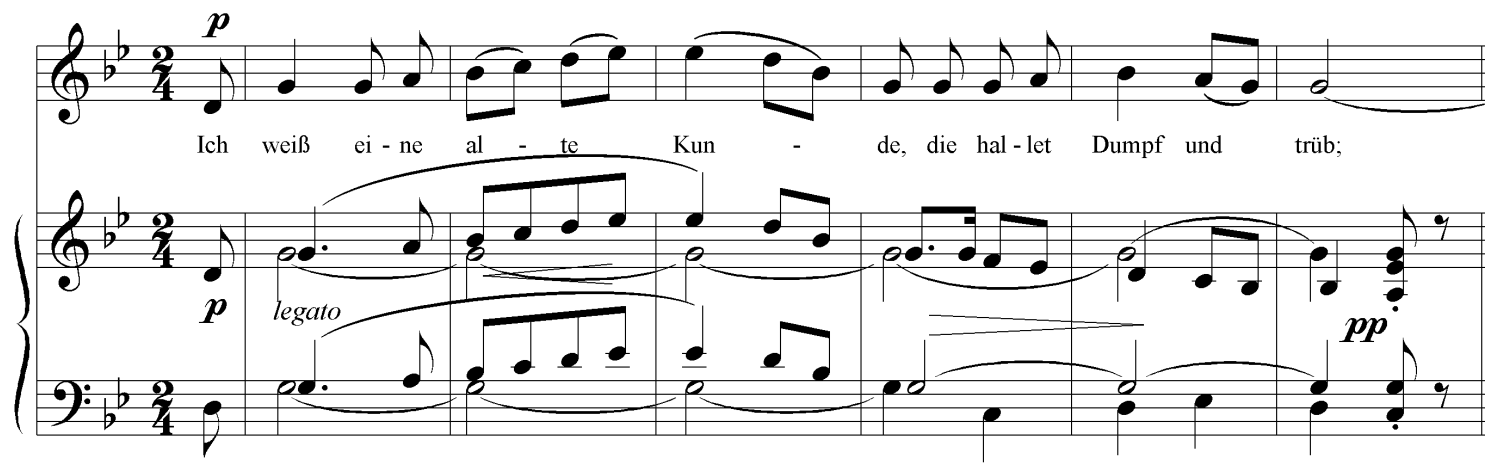

PIGNATARI, Dante (Ed.). Canções para voz e piano. São Paulo: EDUSP, 2004, p. 63.

Drömd lycka (Felicidade sonhada) é outra canção brahmsiana, agora sobre texto em norueguês de autor desconhecido:

\footnotetext{
15 "A influência da canção folclórica sobre os lieder de Brahms é uma das causas do tratamento predominantemente diatônico que ele dá à melodia. [...] Até mesmo seus baixos se movem na maior parte das vezes diatonicamente, e o movimento cromático está presente somente nas partes internas. [...] Embora Brahms não fosse contrário à idéia da clarificação por meio das cores tonais, ele não utilizava esse método. O acompanhamento de suas canções são expressivos, mas não 'plásticos'. Ele não gostava de prelúdios ou pósludios pianísticos extensos, mas começava diretamente com a canção (também uma característica da canção folclórica). "Hoje em dia a canção se desencaminhou tanto que é preciso aterse o mais possível ao próprio ideal, e esse ideal é a canção folclórica', escreveu ele a Clara Schumann.” (BECKER, 1980, p. 172).
} 
EXEMPLO 27: A. Nepomuceno. Drömd lycka, c. 1-3

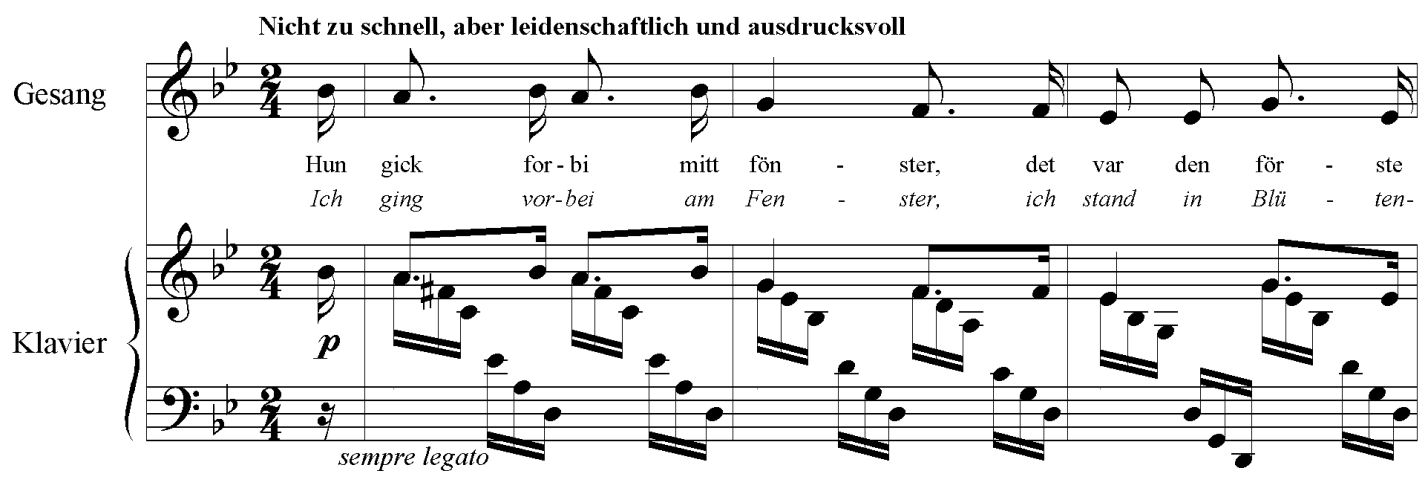

PIGNATARI, Dante (Ed.). Canções para voz e piano. São Paulo: EDUSP, 2004, p. 66.

A peça quase certamente foi composta como oferenda de núpcias, já que o ano da composição e o do casamento de Nepomuceno coincidem.

Em julho de 1893 casa-se com Walborg Bang em Christiania (Oslo), na Noruega. O casal teria quatro filhos: Eivind, Sigurd, Sigrid e Astrid. Nepomuceno conhecera Walborg na classe de Theodor Lechetizky (1830-1915), durante sua permanência em Viena nas férias de 1891. Na época de seu casamento, Nepomuceno ter-se-ia hospedado em casa de Grieg. Luiz Heitor comenta que o compositor teria conhecido bem a casa de Grieg em Troldhaugen (Trondheim). Infelizmente, não pudemos encontrar nenhuma carta trocada entre eles ou em que o compositor se referisse a Grieg. Um único bilhete, de Grieg à sua aluna Walborg Bang, foi exibido na Exposição Comemorativa do Centenário de Nascimento de Alberto Nepomuceno na Escola Nacional de Música. Segundo Sérgio Nepomuceno Alvim Corrêa, esse bilhete foi posteriormente destruído por um incêndio. De qualquer modo, Nepomuceno certamente teve contato com a obra de Grieg, ao menos por intermédio de Walborg, que incluía obras desse compositor em seu repertório, como pode ser confirmado pelo programa do concerto realizado no Clube dos Diários a 6 de maio de 1902, entre outros ${ }^{16}$. (VERMES, 1996, p. 33).

O compositor norueguês, contemporâneo mais velho de Nepomuceno, pode ter sido um de seus modelos, ao menos na utilização do folclore e principalmente da língua nacional em canções. Em 1900 Grieg escreveu a seu biógrafo americano, Henry Finck:

Como é que minhas canções representam um papel tão importante em minha produção? Muito simplesmente devido à circunstância de que até eu, como outros mortais, fui uma vez em minha vida dotado de Gênio (para citar Goethe). O raio de gênio foi: amor. Eu amei uma jovem que tinha uma voz maravilhosa e um igualmente maravilhoso dom de interpretação. Essa jovem se tornou minha esposa e minha companheira por toda a vida, até o dia de hoje. Para mim ela tem sido - eu ouso admiti-lo - a única intérprete genuína de minhas canções.

\footnotetext{
${ }^{16}$ Um outro indício do possível contato com Grieg é a edição da Suíte Antiga para piano feita pela mesma editora de Grieg, Brödrene Hals, de Oslo, que na capa se diz proprietária dos direitos para os países escandinavos. Dificilmente uma obra de Nepomuceno teria sido editada na Noruega sem uma recomendação. Infelizmente, não nos foi possível determinar a data dessa edição norueguesa.
} 
Mesmo que não possamos concluir a partir desta carta que Nina Grieg foi a fonte de inspiração direta de todas as 140 canções de seu marido, ela o foi ao menos para as Melodias do coração op. 5, e foi por meio de sua colaboração que Grieg atingiu sua notável compreensão das capacidades e possibilidades expressivas da voz humana. [...]

Formalmente, as canções são sobretudo simples: em geral estróficas, às vezes com variações estróficas; exemplos de Durchkomponierung ${ }^{[17]}$ são relativamente poucos. A forma estrófica simples semelhante à canção folclórica é especialmente característica e apropriada às adaptações de Vinje e Garborg, onde os textos são na realidade modelados a partir da poesia folclórica norueguesa, e a forma nessas peças é parte integral daquilo que as distingue: canção folclórica transmutada em música erudita. (GRINDE, 1980).

Em abril de 1892, Nepomuceno transfere-se da Akademische Meister Schule para o conservatório Stern.

O diploma do conservatório Stern, datado de 21 de março de 1894, atesta que Nepomuceno teve um aproveitamento excepcional no meio ano que cursou de órgão, chegando a tocar peças difíceis como a Fuga sobre o nome de Bach de Schumann; apresentou grandes progressos técnicos no piano, revelando uma interpretção cálida e concepção musical, e regeu uma Suíte para orquestra de cordas e um Scherzo para grande orquestra, peças de sua composição, ante a Orquestra Filarmônica de Berlim. (VERMES, 1996, p. 33).

Do mesmo ano em que concluiu o curso em Berlim é o ciclo de cinco canções sobre poemas de Nikolaus Lenau, evidentemente seu trabalho de formatura na área do lied. Os lieder de Nepomuceno, ou seja, as duas canções brahmsianas e este ciclo, que incorpora a linguagem wagneriana, são reflexo da absorção do material que alimentava a principal polêmica que se desenvolvia no mundo germânico em relação à canção enquanto gênero:

Boa parte do debate sobre canções no final do século 19 procurava demarcar uma oposição entre os ideais ligados ao folclore para o gênero - tal como manifesto nas formas fechadas estróficas ou ternárias e melodias claramente definidas - e os estilos dramáticos mais livres influenciados pelo drama musical wagneriano. [...]

Para Brahms, o ideal folclórico tinha na verdade assumido um grau pouco comum de substância, já que o compositor tinha se adequado às formas e estilos literais da canção folclórica em determinadas coleções, dando assim a si mesmo uma medida concreta para a prática musical de suas canções mais desenvolvidas. Há uma distinção estilística clara entre os dois tipos de composição de canção, mas a partir daí o 'ideal' tinha sido ancorado na prática e aspectos específicos tinham sido transportados para o estilo mais avançado. Ironicamente, Wagner e os wagnerianos também rendiam homenagem a uma canção folclórica ideal, mas em geral, e em contraste com essa postura, viam-na como algo intocável, envolto em referências nostálgicas ao passado germânico e, portanto, como algo que não devia ser integrado à prática cotidiana. (GLAUERT, 1999, p. 36-37)

\footnotetext{
${ }^{17}$ Segundo o Dicionário de música Zahar (ISAACS..., 1985), durchkomponiert é a "canção em que a música é diferente para cada verso (? - provavelmente má tradução do inglês: verse = estrofe) do poema, por oposição à canção estrófica; mas o uso do termo ampliou-se para abranger qualquer peça 'inteiramente composta', por oposição àquela que tem seções repetidas.
} 
Não há modelo único no ciclo Lenau. A primeira canção, Einklang (Ressonância), que funciona como prelúdio, assinala a descoberta da harmonia wagneriana. Em contradição com a armadura de clave sem acidentes, a introdução feita pelo piano assinala claramente fá maior como tonalidade principal, e acontece sobre a nota mi repetida doze vezes no registro mais grave do instrumento, gerando a ambiguidade harmônica cromática típica da música de Liszt e Wagner, ambiguidade esta que perdura até o final da canção:

EXEMPLO 28: A. Nepomuceno. Einklang, c. 1-7

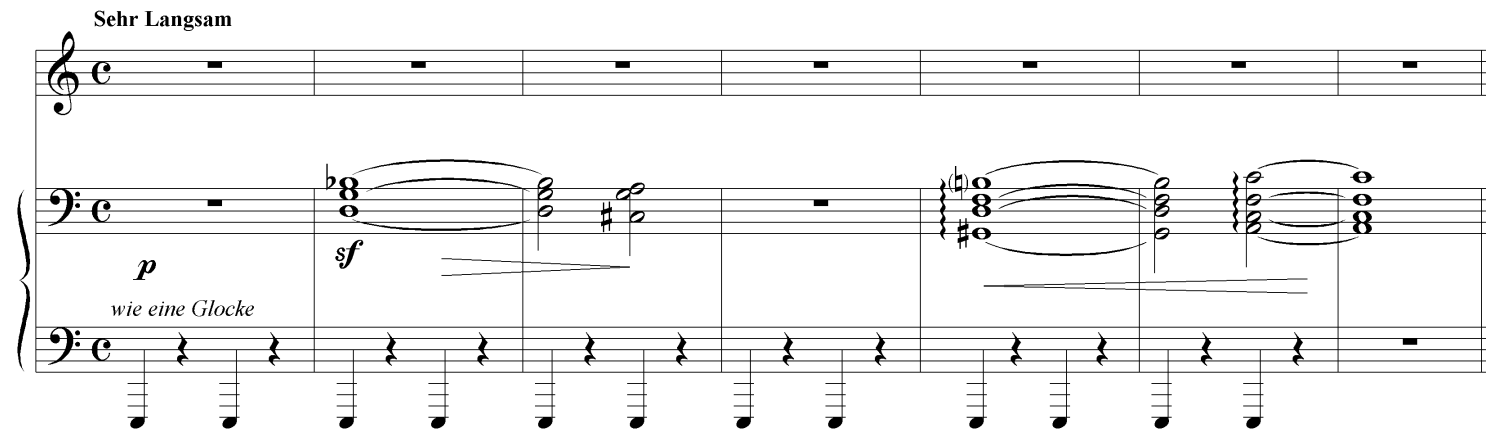

PIGNATARI, Dante (Ed.). Canções para voz e piano. São Paulo: EDUSP, 2004, p. 69.

No centro da peça temos seu ponto culminante, a modulação para mi bemol maior dos compassos 14 a 16 :

EXEMPLO 29: A. Nepomuceno. Einklang, c. 14-16

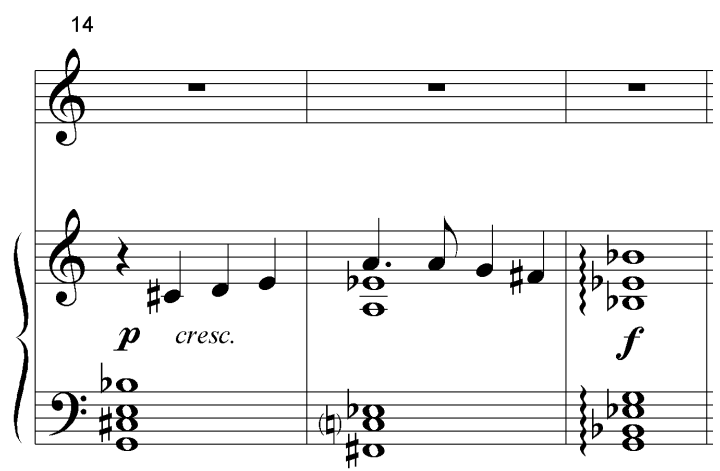

PIGNATARI, Dante (Ed.). Canções para voz e piano. São Paulo: EDUSP, 2004, p. 69.

A partir daí a harmonia evolui para mi maior, acorde que encerra a canção com forte caráter de dominante. A análise harmônica sugere a tonalidade de lá menor, oculta. 
O material melódico é modelado de acordo com o arioso wagneriano, sendo as frases construídas sempre sobre acordes diminutos. O mesmo tipo de recitativo reaparece na terceira peça, Herbst (Outono):

EXEMPLO 30: A. NEPOMUCENO. Herbst, c. 1-9

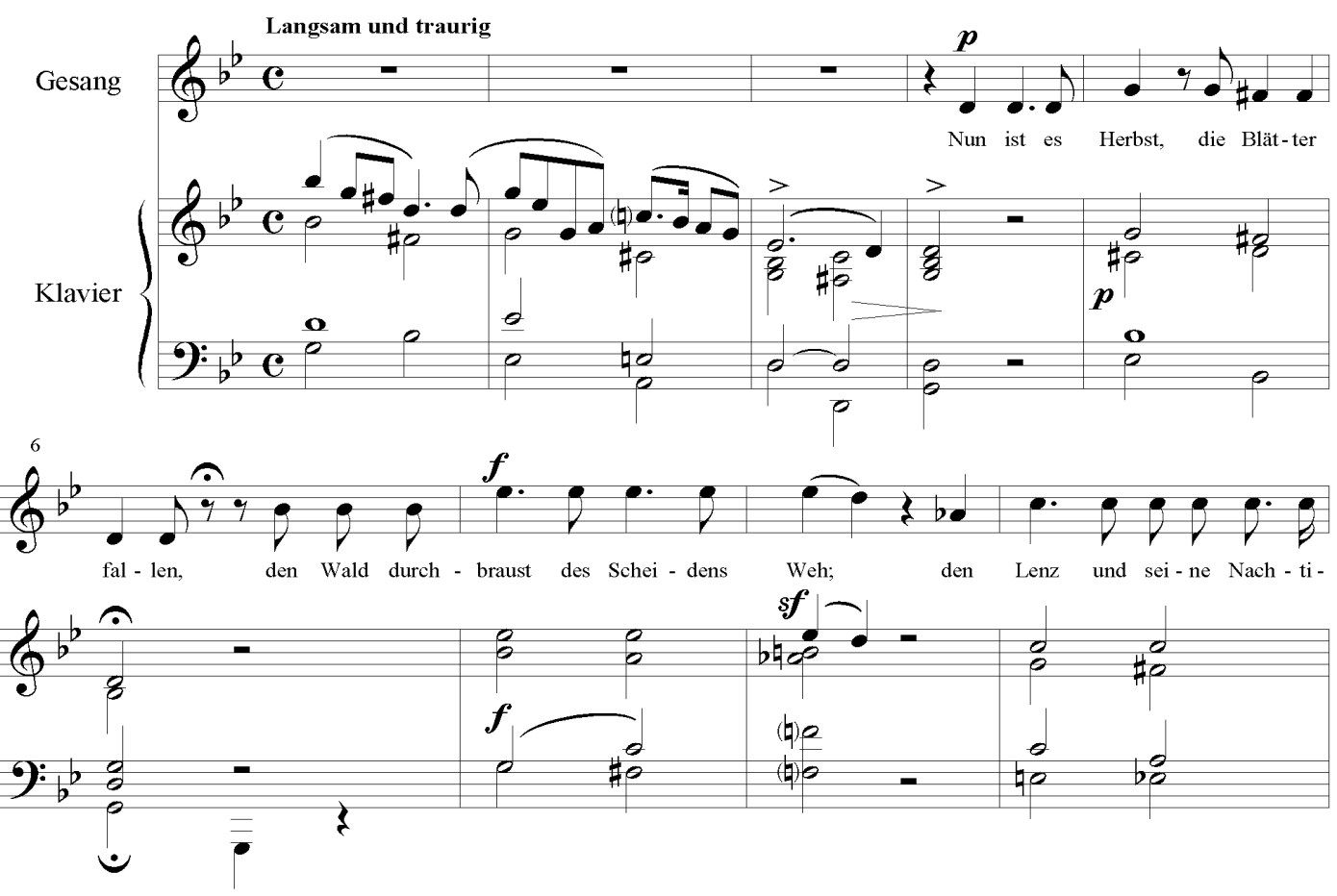

PIGNATARI, Dante (Ed.). Canções para voz e piano. São Paulo: EDUSP, 2004, p. 72.

Nesta última temos uma pista de um possível modelo provavelmente estudado por Nepomuceno em Berlim no motivo cantado nos compassos 8-9, uma citação quase literal de um dos leitmotive do primeiro ato de A Valquíria, de Wagner:

EXEMPLO 31: R. WAGNER. A Valquíria, Ato I

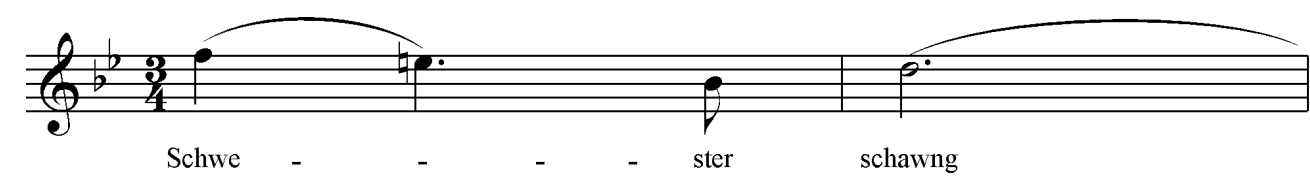

R. Wagner. Die Walküre. Nova Iorque: Dover, 1978, p. 104, c. 2-3.

Herbst é uma canção estrófica em que o prelúdio pianístico reaparece duas vezes separando as estrofes, além de servir também de coda para concluir a peça. A última estrofe é mais movimentada (a indicação de andamento é Mehr bewegt), e o acompanhamento, em 
acordes simples nas duas primeiras estrofes, é aqui enriquecido por trêmolos que enfatizam o caráter mais dramático dos versos que lamentam a juventude para sempre perdida e configuram de maneira eficiente uma variação de caráter e ao mesmo tempo um clímax, após o qual resta somente concluir a canção:

EXEMPLO 32: A. NEPOMUCENO. Herbst, c. 28-32

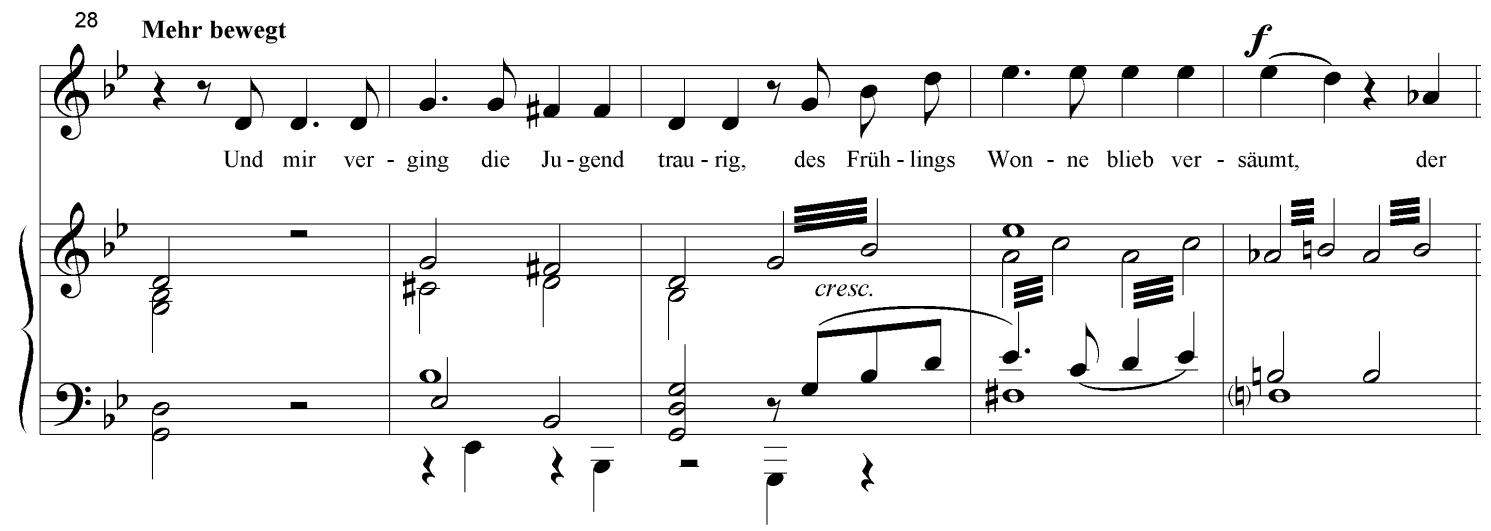

PIGNATARI, Dante (Ed.). Canções para voz e piano. São Paulo: EDUSP, 2004, p. 73.

Intercaladas com estas peças de caráter mais recitativo, temos duas canções "melódicas", de estilo mais brahmsiano. A segunda canção do ciclo, $O$ wag'es nicht, é uma variação do perfil melódico do último motivo cantado de Einklang:

EXEMPLO 33: A. NEPOMUCENO. Einklang, c. 22-23.

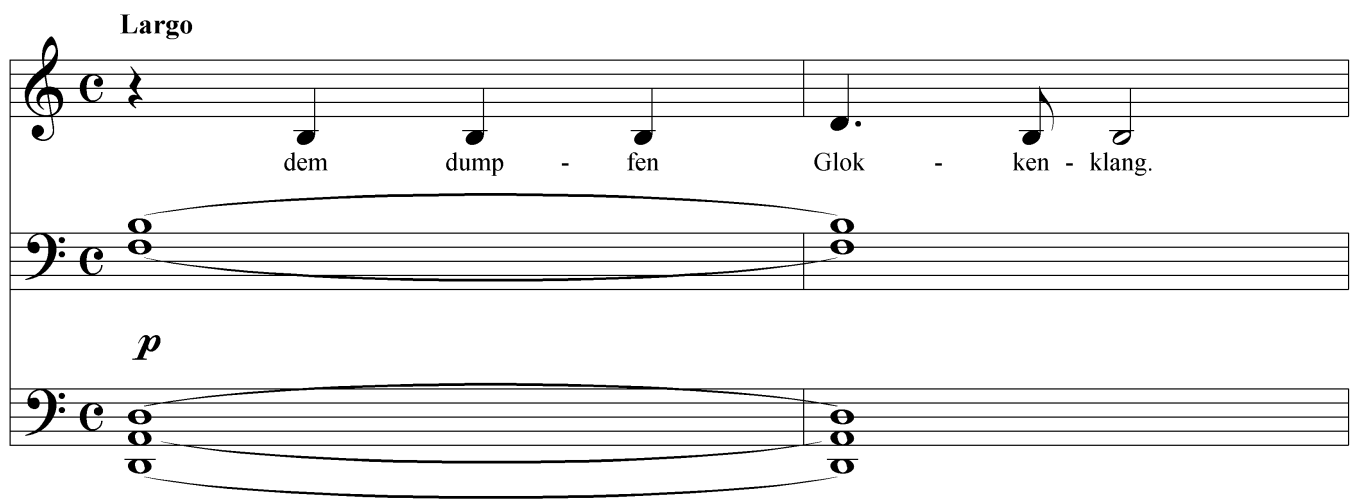

PIGNATARI, Dante (Ed.). Canções para voz e piano. São Paulo: EDUSP, 2004, p. 69.

Este, agora, em contraste com o caráter recitativo da canção anterior, evolui em um ritmo ternário vivo (Bewegt) e inquieto: 
EXEMPLO 34: A. NEPOMUCENO. O wag'es nicht, c. 1-7.

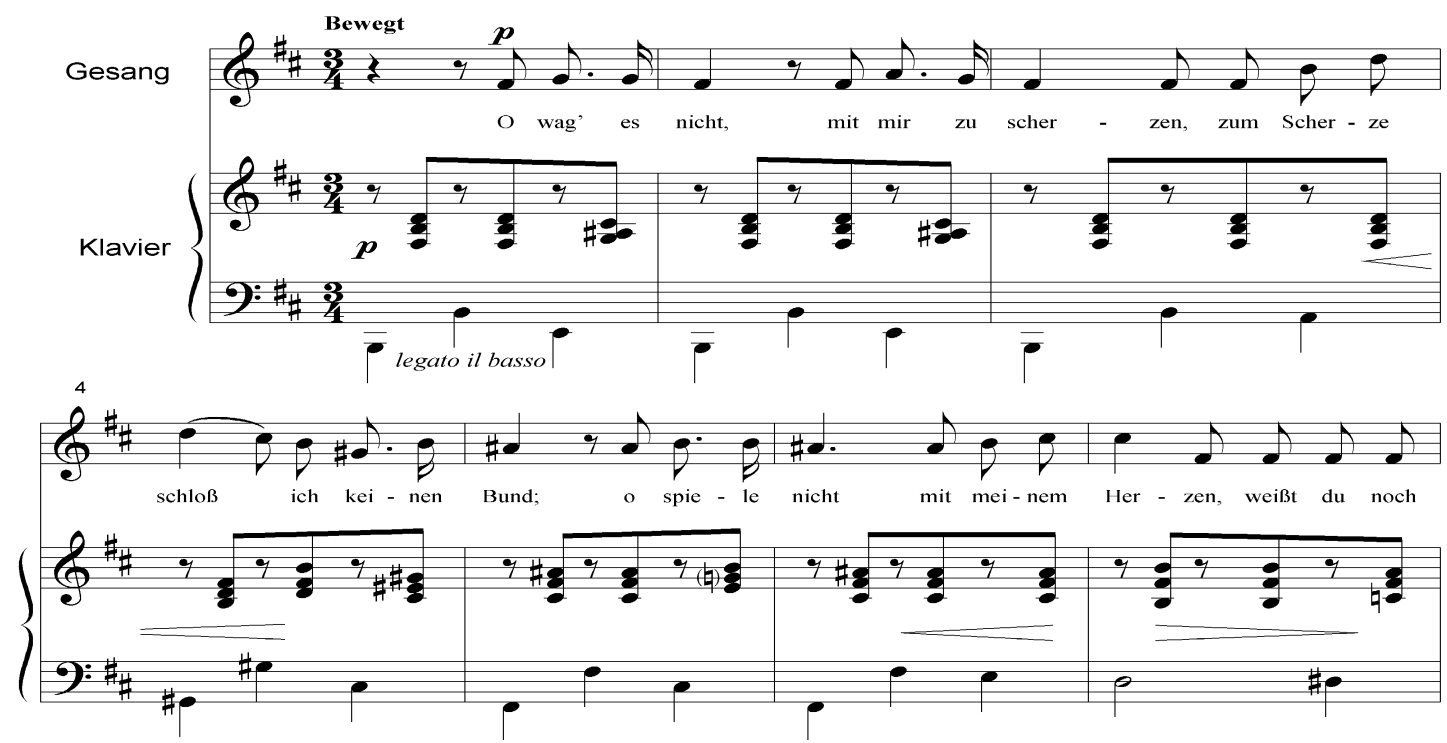

PIGNATARI, Dante (Ed.). Canções para voz e piano. São Paulo: EDUSP, 2004, p. 70.

A canção é estrófica, mas a música para cada estrofe não é exatamente igual, sendo a variação mais acentuada na terceira, onde o ponto culminante é alcançado nos compassos 2224:

EXEMPLO 35: A. NEPOMUCENO. O wag'es nicht, c. 21-26.

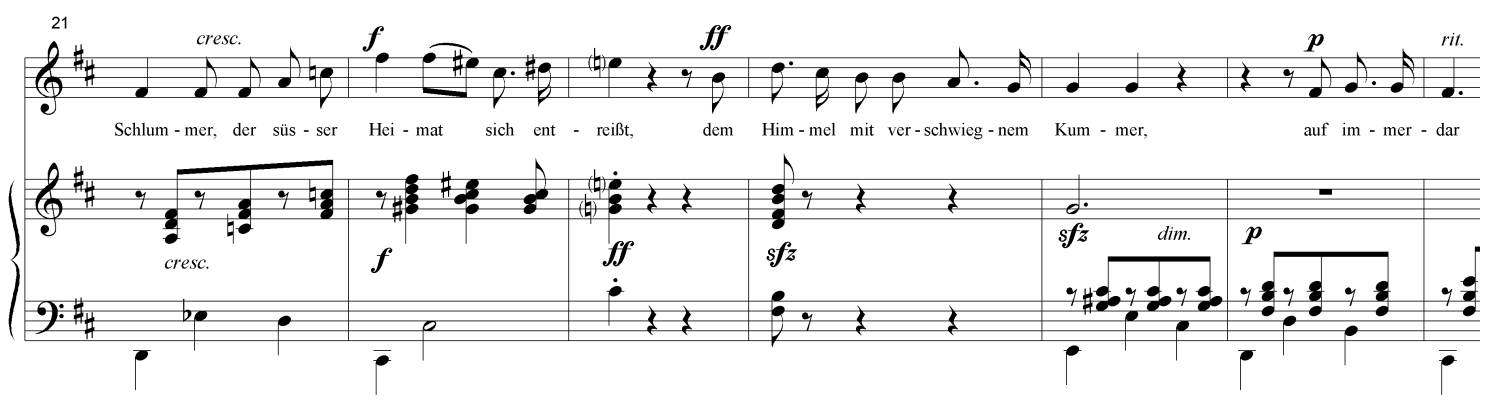

PIGNATARI, Dante (Ed.). Canções para voz e piano. São Paulo: EDUSP, 2004, p. 71.

A peça conclui com o motivo inicial dos primeiros compassos, ritenuto e diminuendo.

A quarta peça do ciclo, Wiege sie sanft, o Schlaf, é a única na forma-canção tradicional derivada da aria da capo, $\mathrm{ABA}$, necessária para acomodar o poema, que conclui repetindo a primeira estrofe. Nesta repetição, a melodia reaparece inalterada, mas harmonizada no modo menor, mais precisamente em ré menor, a relativa da dominante. A mudança de modo ilustra a ambiguidade do poema, em que o sono que embala a criança (trata-se de fato de uma canção de ninar) pode ser o sono da morte: 
EXEMPLO 36: A. NePOMUCENO. Wiege sie sanft, o Schlaf, c. 3-6 e c. 54-57
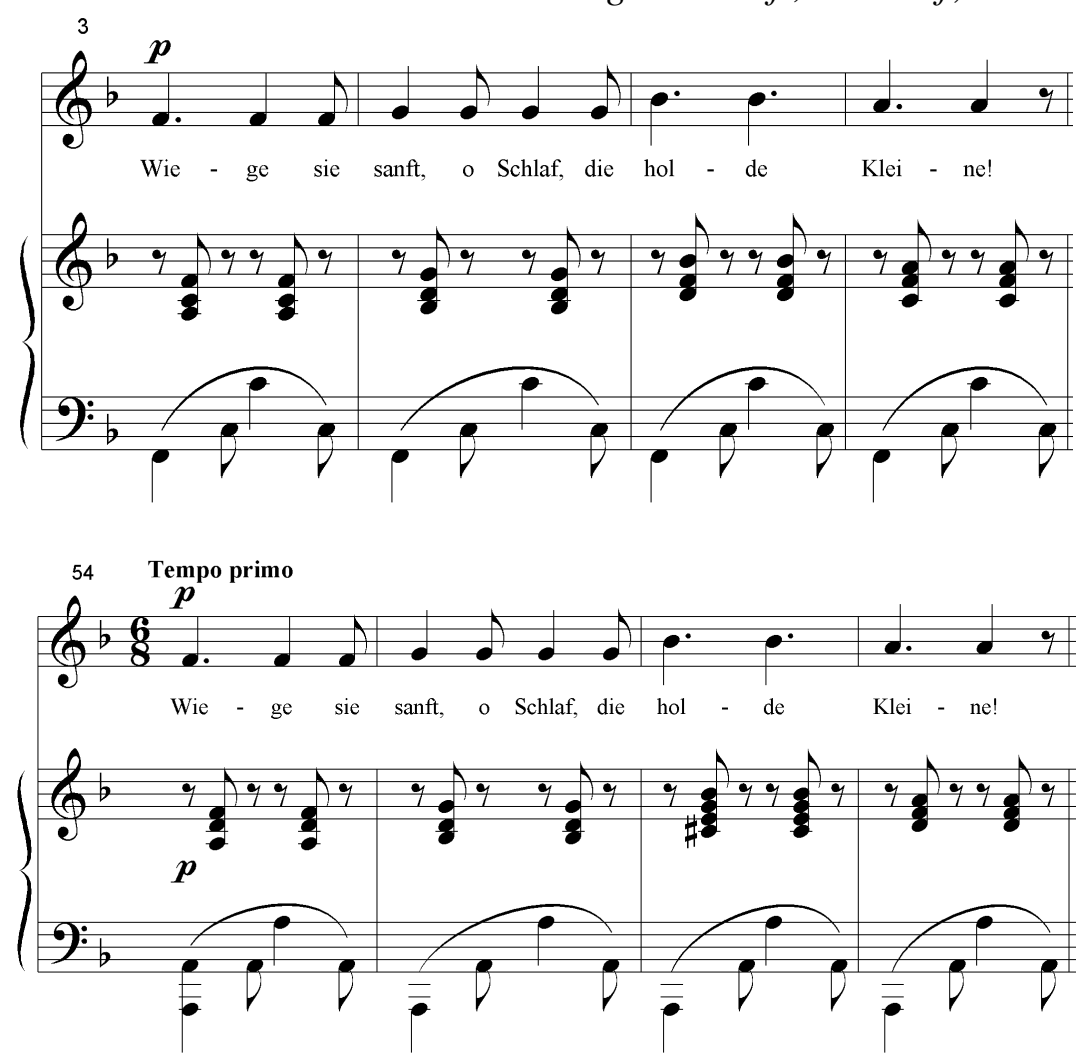

PIGNATARI, Dante (Ed.). Canções para voz e piano. São Paulo: EDUSP, 2004, p. 74 e p. 77 respectivamente.

Já a semelhança da última peça, Sehnsucht nach Vergessen (Ânsia de esquecimento) com Der Atlas, de Schubert, é por demais óbvia para passar desapercebida: 
EXEMPLO 37: A. NEPOMUCENO. Sehnsucht nach Vergessen, c. 1-14.
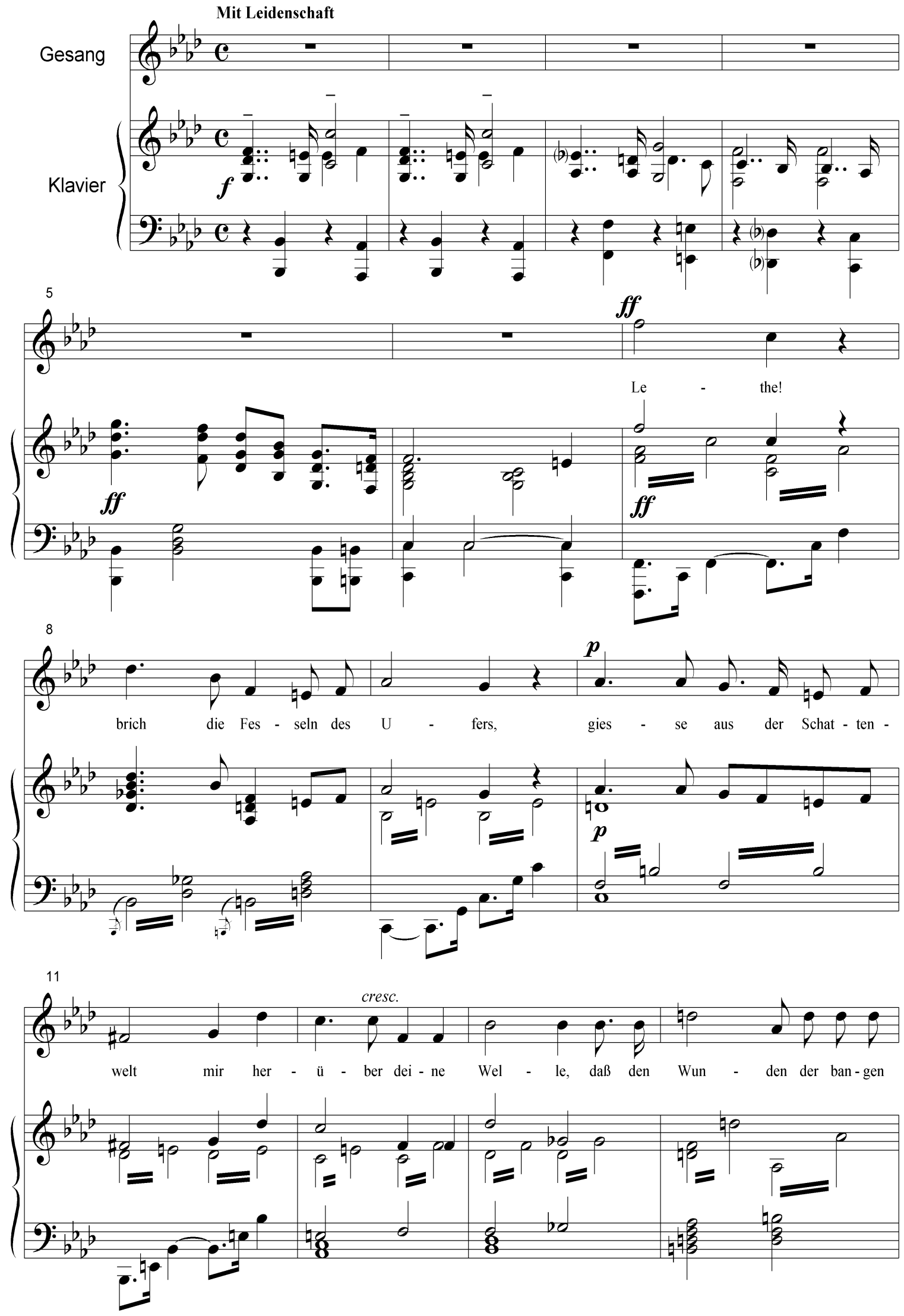

PIGNATARI, Dante (Ed.). Canções para voz e piano. São Paulo: EDUSP, 2004, p. 78. 
EXEMPLO 38: F. SCHUBERT. Der Atlas, c. 1-17.

Singstimme.
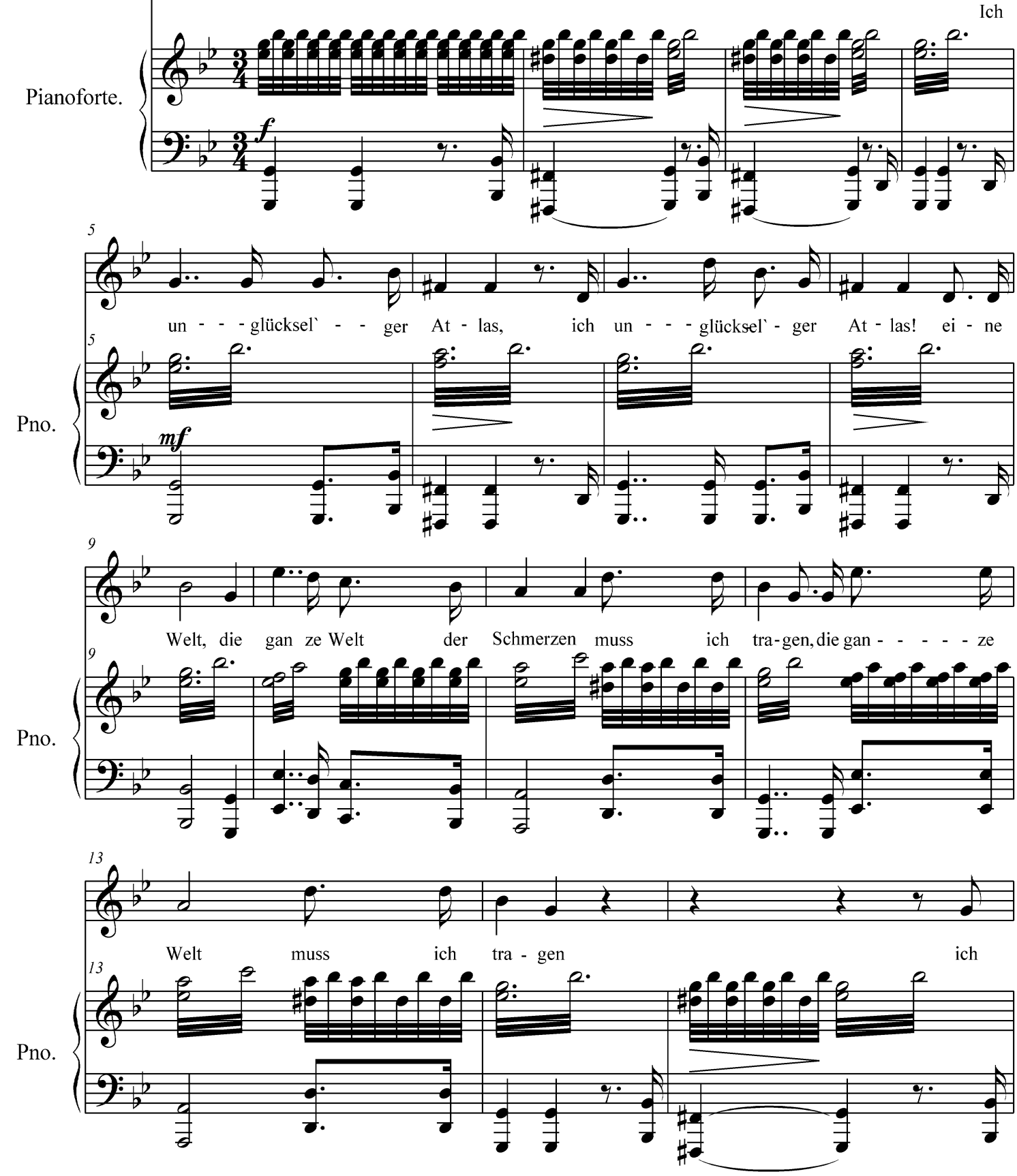

MANDYCZEWSKI, Eusebius (Ed.). Complete Song Cycles. Nova York: Dover, 1970, p. 167. 
Cada uma das cinco peças do ciclo é um tipo diferente de canção: um arioso wagneriano inicial à guiza de prelúdio, uma canção estrófica variada a la Brahms, uma canção estrófica quase estrita de caráter recitativo, uma peça em forma de canção e, para concluir, um brado quase operístico, quase uma aria di furore. Nos parece natural, e é evidente, que Nepomuceno não tenha pretendido a originalidade como compositor de lieder. Essas canções são seu trabalho de conclusão de curso no campo da canção romântica germânica. 
Nepomuceno estudou por quatro anos em Berlim, de 1890 a 1892 na Akademische Meisterschule, e no Conservatório Stern nos dois anos seguintes. Neste, teve aulas de composição e órgão com Arno Kleffel, além de piano com H. Ehrlich. No dia 17 de abril de 1894 é nomeado professor de órgão do Instituto Nacional de Música (INM) do Rio de Janeiro. Nepomuceno assume no dia 27 de junho de 1895, na Legação do Brasil em Paris:

\begin{abstract}
Uma vez concluído o curso em Berlim, Nepomuceno segue para Paris, onde estuda órgão com Alexandre Guilmant (1837-1911) no Conservatório de Paris, com o objetivo de se aperfeiçoar no instrumento para o qual havia sido nomeado professor no INM. Nessa permanência em Paris, tem a oportunidade de conhecer a produção musical de Debussy (assiste à estréia do Prélude à l'après midi d'un faune) e conhece Saint-Saëns, Charles Bordes e Vincent D’Indy.” (VERMES, 1996, p. 34).
\end{abstract}

O que mais nos chama a atenção nos parcos dados que temos da estadia de Nepomuceno em Paris é o contato com a produção contemporânea francesa, representada aqui por nada menos que o Fauno de Debussy. Vimos como o jovem brasileiro aproveitou seus anos de estudos na Alemanha para absorver a linguagem harmônica de Wagner, de cuja influência nenhum compositor europeu atuando no final do século 19 escapou. Nepomuceno permaneceu um ano em Paris, e as canções lá produzidas marcam a sua maioridade como compositor do gênero. Foram seis as peças em francês produzidas nesse período que chegaram a nós ${ }^{18}$, quatro sobre textos de Henri Piazza e duas ambientações de poemas de Maeterlinck.

As quatro canções sobre poemas de Piazza mostram o quanto Nepomuceno se sente à vontade com a linguagem da mélodie. As peças são impecavelmente francesas, no idioma musical, nas melodias e especialmente na harmonia. Somente na presença dessas canções é que nos damos conta do quanto as tentativas anteriores eram ainda estudos, exercícios de um jovem compositor em formação. Há uma desenvoltura inédita na ambientação musical dos poemas, e se nessas peças reconhecemos o quão francesas são, aqui, ao contrário do que acontece com os lieder de Berlim, não é possível reconhecer nenhum modelo imediato. Muito de Fauré, de Debussy, mas facilmente também poderíamos encontrar traços de Chausson, Saint-Saëns, D’Indy ou Duparc. O que quero dizer é que elas são originais. E é isso o que

\footnotetext{
${ }^{18}$ Uma sétima canção, Chanson de Gelisette, sobre versos de Maeterlinck, está extraviada.
} 
mais surpreende, a profunda compreensão da música francesa de seu tempo e o poderio composicional que demonstra ao criar música francesa contemporânea original, como se fosse um compositor nativo. E mais ainda, não um compositor qualquer: o artesanato impecável e a maleabilidade da linguagem musical ao adaptar-se às palavras que observamos nas canções sobre textos de Piazza só se dão nas mãos de um mestre.

Mas são principalmente as duas ambientações de Maeterlinck que nos levam a reconhecer essa maestria alcançada pelo cearense, coisa de que aparentemente ele mesmo se deu conta. A primeira razão que leva a essa conclusão é o fato de no manuscrito de Oraison constar a inscrição "opus $11 \mathrm{n}^{\mathrm{o}} 2$ " 19 . É de se supor que o outro texto de Maeterlinck ambientado por Nepomuceno, Désirs d'hiver, seria o ${ }^{\circ} 1$ do mesmo opus ${ }^{20}$. Colocar número de opus para publicação, em qualquer caso, revela que o compositor assume e se orgulha de sua produção. Para citar um único caso, aqui contrário, o imensamente popular ImpromptuFantaisie de Frédéric Chopin somente foi publicado postumamente pois, apesar de composição muito superior ao modelo original, era obviamente calcado em uma obra de outro virtuose contemporâneo, Ignaz Moscheles. Nepomuceno ainda não tinha publicado nenhuma canção com número de opus, e ter pensado em fazê-lo com estas canções as assinala como o ponto em que ele acreditava ter atingido a maioridade no gênero. A análise das peças o confirma. Já o fato dessas canções terem sido publicadas ao fim e ao cabo sem número de opus revela talvez um gesto nacionalista do nosso compositor: apesar do compreensível entusiasmo inicial com Désirs d'hiver e Oraison, o número de opus inaugural das canções ficaria reservado para as primeiras peças em português, seu opus 12, produzidas ainda em Paris e tendo já em vista o retorno ao Brasil.

Debussy, à época do Prelúdio à tarde de um fauno, trilhava já com passo firme um novo caminho, na verdade uma reação e uma resposta francesa ao wagnerismo germânico. Nessa empreitada, alinhou-se com a vanguarda literária de sua época, representada pelos poetas simbolistas e cujo maior representante era Stéphane Mallarmé, autor do poema L'aprés-midi d'un faune que inspirou o Prelúdio de Debussy.

\footnotetext{
${ }^{19}$ Ver observação no Catálogo Geral, relação de obras para canto e piano (p. 46), 8.17: Oraison.

${ }^{20}$ Nepomuceno gostava de agrupar suas canções em pares contrastantes: são doze pares com número de opus, além dos pares óbvios sobre textos de Tagore (Candura e Flores), Bilac (Numa concha e Olha-me!) e Hermes Fontes (Canção da ausência e Luz e névoa).
} 
Trabalhando em Diane au bois, ele [Debussy] escreveu de Roma a M. Vasnier em 1886: 'Pode ser de fato que eu tenha assumido uma tarefa que é demasiado para mim; não há nenhum precedente, e eu portanto sou obrigado a inventar novas formas. Eu poderia me voltar para Wagner, mas não é preciso que eu explique a loucura de tal tentativa'. [...]

O primeiro fruto dessa busca por uma música que fosse imaginada com precisão mas ainda assim fluida e desembaraçada de regras foi L'aprés-midi; significativamente, uma obra baseada em um poema simbolista. Debussy reconhecia nos escritos de Baudelaire, Verlaine e especialmente Mallarmé não somente a fantasia e a liberdade que faltavam na música contemporânea, mas também uma concentração do sentimento.” (NICHOLS, 1980).

Além do projeto de criação de uma música brasileira, que, como queremos demonstrar neste trabalho, Nepomuceno pôs em prática nas canções para voz e piano, o compositor teve outra ambição: para que o Brasil pudesse se tornar uma fonte geradora de música de valor internacional, era preciso inseri-lo na vanguarda da música européia. Nepomuceno é o grande responsável por trazer a modernidade à música brasileira, modernidade esta representada especialmente por Wagner, do lado germânico, e Debussy do francês. Essa inclinação pela vanguarda e a luta pela inserção do Brasil na modernidade musical internacional se revela com toda clareza na tentativa feita bem mais tarde, em 1916, de fazer com que o Instituto Nacional de Música adotasse o avançadíssimo Tratado de Harmonia de Arnold Schoenberg (1874-1951). Nepomuceno começara inclusive a traduzir a obra, que tinha sido publicada em Viena em 1911, mas a iniciativa foi frustrada pela resistência do conservador corpo docente da instituição ${ }^{21}$. É compreensível o fascínio de Nepomuceno por essa obra: somente o Tratado de Schoenberg dava conta das ousadias harmônicas de Oraison.

Não sabemos exatamente que música Nepomuceno leu e estudou na Europa, mas a sofisticada linguagem harmônica das canções sobre textos de Maeterlinck, especialmente Oraison, alinham o compositor brasileiro com o que de mais vanguardista se fazia na Europa dos últimos anos do século 19. O verso inicial de Oraison, um clamor lamentoso à divindade, repete o perfil melódico e o início fortissimo diminuendo a piano do primeiro verso de Sehnsucht nach Vergessen, última canção do ciclo Lenau e que tem o mesmo caráter na concepção de Nepomuceno: “Conheceis, Senhor, minha miséria!”, em Maeterlinck, e "Letes! rompe a corrente da margem" em Lenau.

\footnotetext{
${ }^{21}$ Ver VERMES, 1996, p. 70, e também CORRÊA, 1996, p. 13.
} 
EXEMPLO 39: A. NePOMUCENO. Oraison, c. 1-2

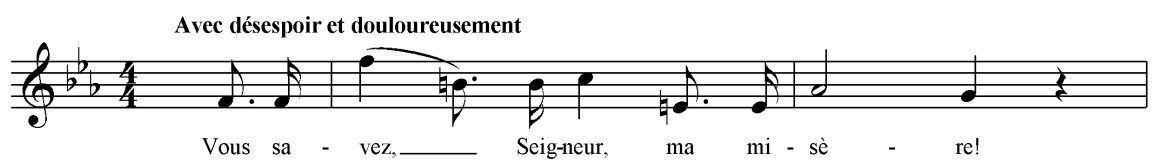

EXEMPLO 40: A. NEPOMUCENO. Sehnsucht nach Vergessen, c. 7-9

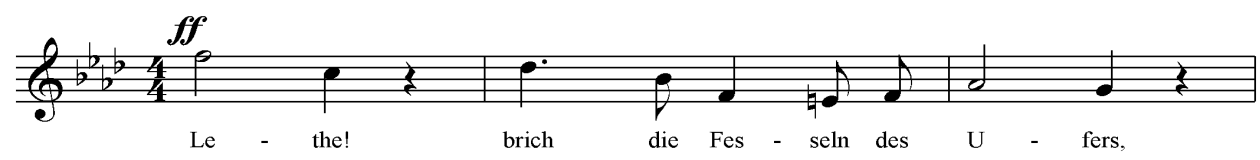

PIGNATARI, Dante (Ed.). Canções para voz e piano. São Paulo: EDUSP, 2004, p. 85 e p. 78 respectivamente.

As semelhanças terminam aqui. A harmonia cromática ambígua, baseada em acordes diminutos e em constante mutação é tipicamente pós-wagneriana, em sua vertente francesa. A primeira frase da canção, ou seja, os quatro primeiros compassos, joga a la Liszt com a ambiguidade cromática entre dó menor, de fato a tonalidade da peça, e ré bemol. Embora termine em um acorde de sétima de dominante, mostrando claramente que dó menor é a tonalidade principal, esse acorde não leva a lugar nenhum:

EXEMPLO 41: A. NEPOMUCENO. Oraison, c. 1-5

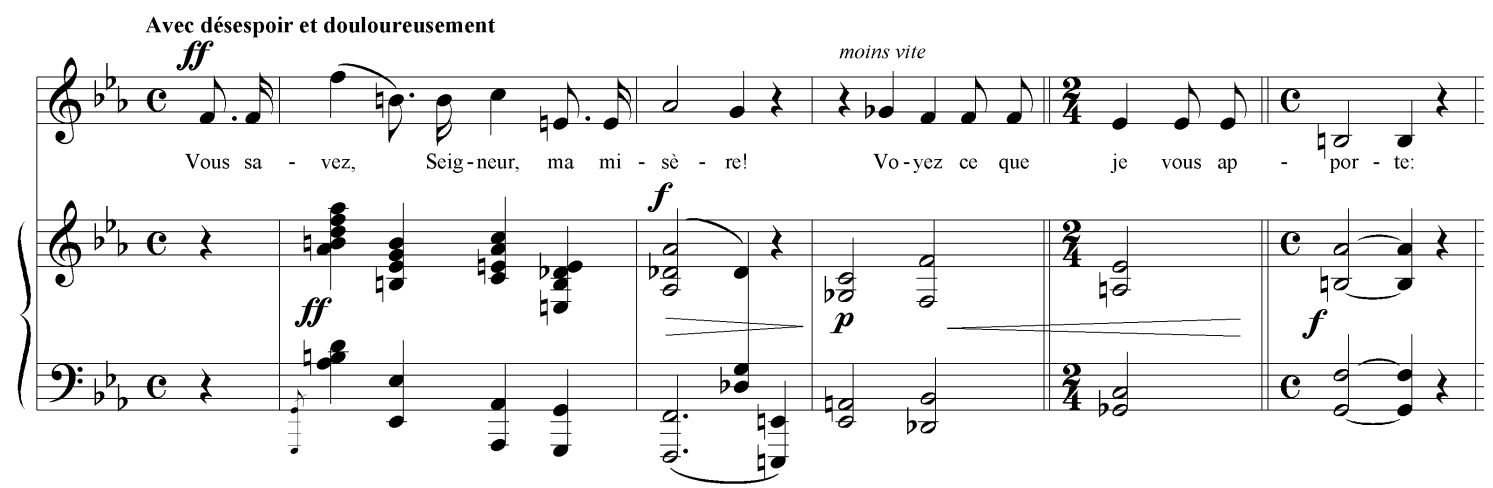

PIGNATARI, Dante (Ed.). Canções para voz e piano. São Paulo: EDUSP, 2004, p. 85.

Inicia-se outra frase descendente ff diminuendo a piano, agora sobre um acorde diminuto que no compasso seguinte indica claramente lá bemol como dominante: 
EXEMPLO 42: A. NEPOMUCENO. Oraison, c. 6-7

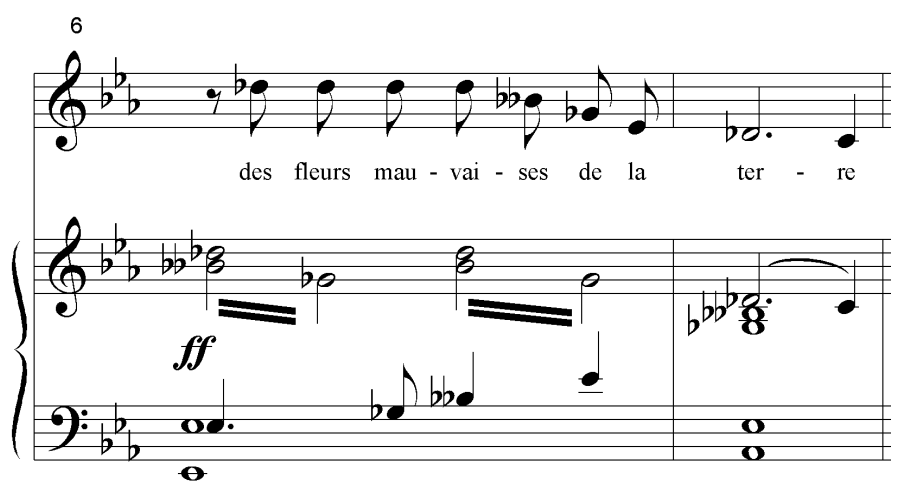

PIGNATARI, Dante (Ed.). Canções para voz e piano. São Paulo: EDUSP, 2004, p. 85.

As resoluções nunca são em um acorde de tônica; uma seqüência de appoggiature que resolvem sempre em outra dominante (essencialmente a técnica básica de modulação contínua utilizada por Wagner em seus dramas musicais) levam a um recitativo executado pelo piano que desenha melodicamente um acorde de mi maior com sétima (c. 10):

EXEMPLO 43: A. NEPOMUCENO. Oraison, c. 8-11

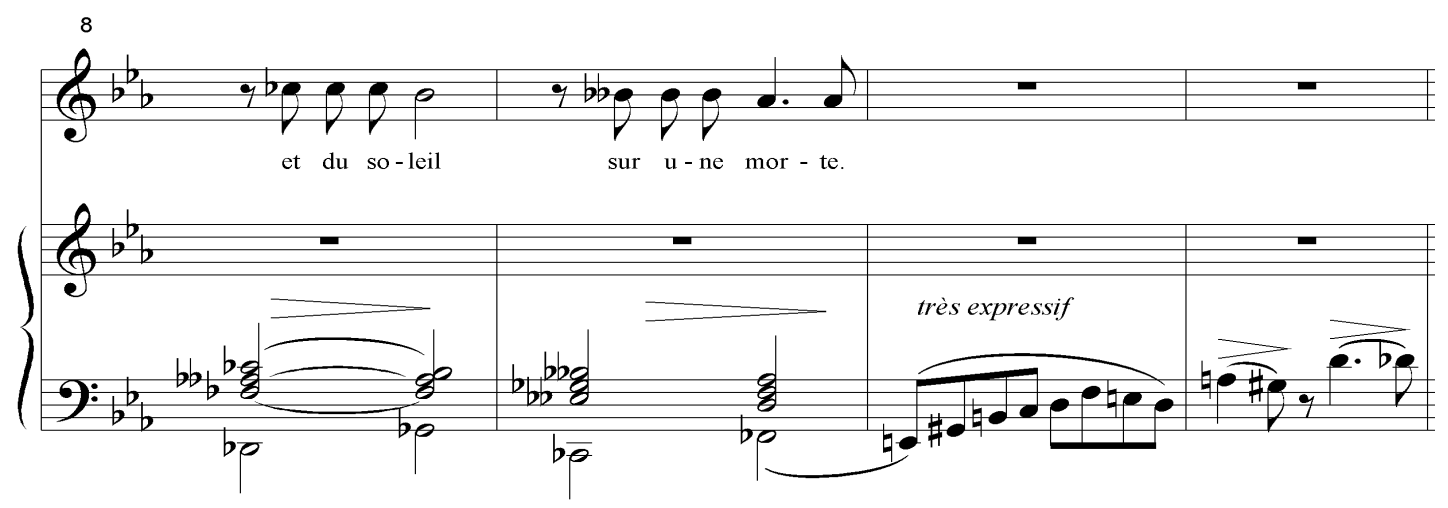

PIGNATARI, Dante (Ed.). Canções para voz e piano. São Paulo: EDUSP, 2004, p. 85.

Essa sequência de resoluções em dominantes prossegue com duas appoggiature melódicas, e poderia finalmente resolver em ré, mas tampouco isso acontece. A tonalidade que finalmente prossegue com a canção após essa suspensão é fá menor. Mas poderia ser qualquer outra ou, pelo menos, muitas outras. O ritmo modulatório intenso faz com que ao final do compasso 11 a tonalidade seja, na verdade, suspensa.

A resolução é singela, na subdominante, e a canção prossegue, sempre em frases descendentes, até a segunda parte, que tem cinco compassos: 
EXEMPLO 44: A. NEPOMUCENO. Oraison, c. 16-21
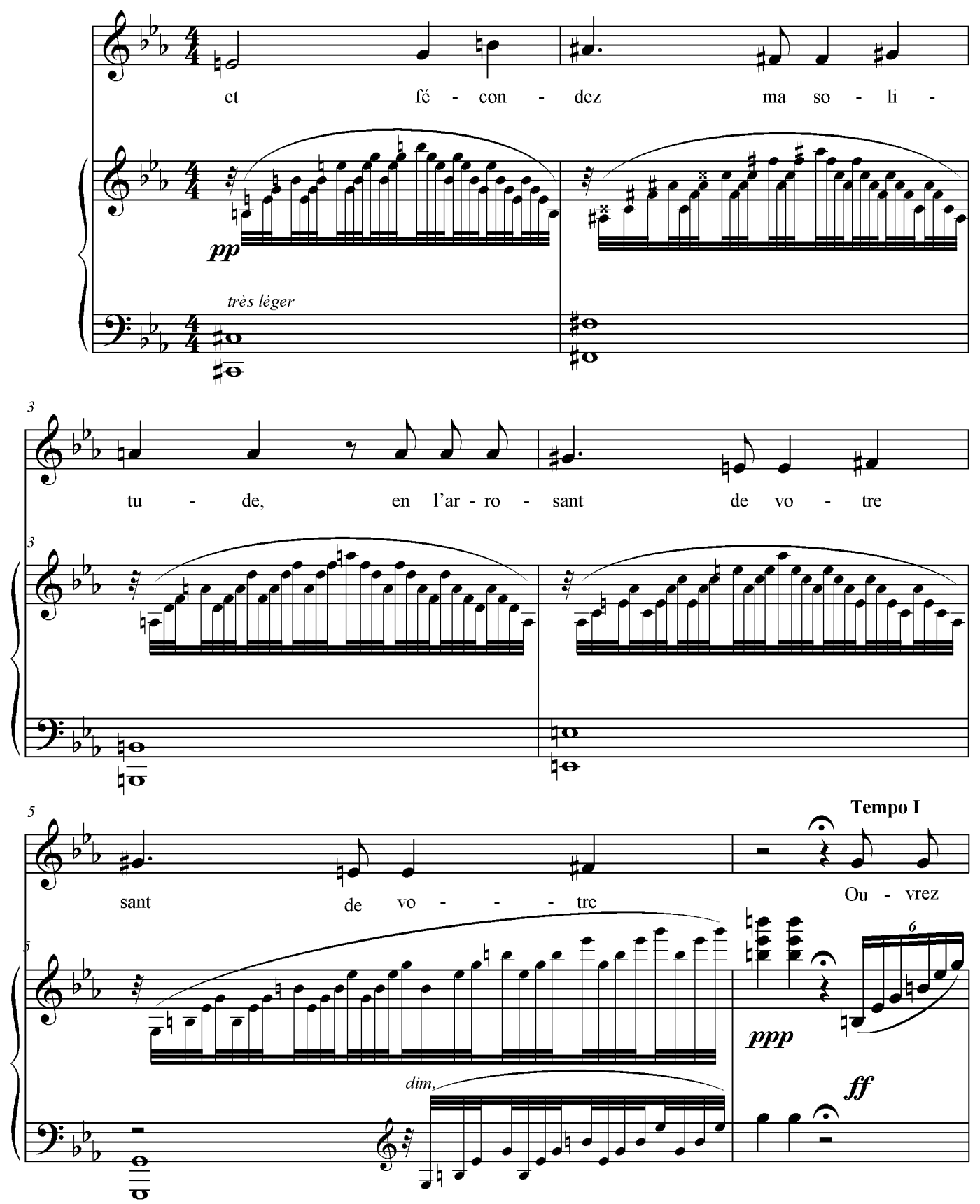

PIGNATARI, Dante (Ed.). Canções para voz e piano. São Paulo: EDUSP, 2004, p. 85-86.

Estes compassos, que dão conta dos versos et fécondez ma solitude, en l'arrossant de votre gloire (e fecundai a minha solidão, regando-a com a vossa glória), estão essencialmente em mi menor, a relativa da dominante, e criam um clima totalmente diverso, suspendendo o ritmo marcado por acordes da primeira parte e criando um efeito de sostenuto, sendo a parte cantada sustentada por acordes agora aumentados e arpejados que levam ao retorno da frase inicial. Esta, a partir da suspensão no acorde de dominante com sétima no compasso 26, 
repetindo o que acontece no compasso 5, leva desta vez, retardada por appoggiature, à conclusão na tônica, que após tantos retardos, e devido ao passeio por tonalidades distantes em peça tão breve, ou seja, por sua pouca presença, dá quase a sensação de comparecer por simples cumprimento do dever. A rigor, a canção bem poderia terminar em outra tonalidade:

EXEMPLO 45: A. NEPOMUCENO. Oraison, c. 21-33

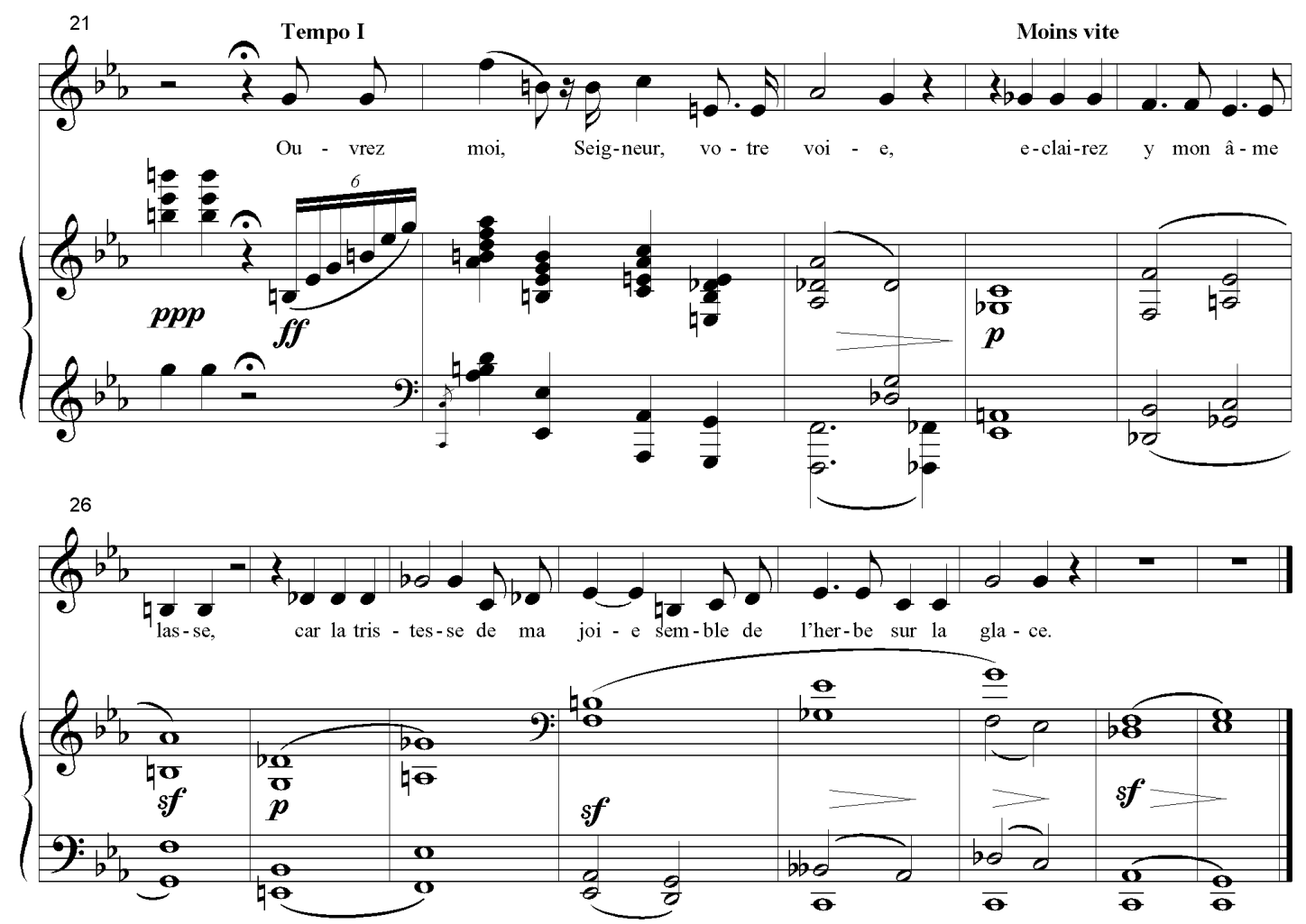

PIGNATARI, Dante (Ed.). Canções para voz e piano. São Paulo: EDUSP, 2004, p. 86.

A métrica está baseada em frases de cinco compassos. Cinco para a primeira frase, dez para a segunda, sendo que os dois compassos centrais (10 e 11) são o recitativo pianístico mencionado acima, 5 + 1 para a parte central, e dez para o final, mais dois para a appoggiatura que conclui a peça. A harmonia é essencialmente cromática, jogando com dó menor / ré bemol na primeira parte e fá menor / mi maior na segunda. O final repete o início, configurando a forma-canção tradicional (ABA).

Oraison é um marco no cancioneiro de Nepomuceno: mostra quão bem fora assimilada a lição wagneriana e, claramente, como o compositor se alinha nesse momento ao que há de mais avançado na vanguarda européia. Nacionalismo e vanguarda: eis as linhas-mestras que o 
guiam nas vésperas de seu retorno ao Brasil. Ele não só ambiciona criar uma música brasileira, ou pelo menos dar início ao processo de sua criação, mas quer que essa música acompanhe a ponta-de-lança da modernidade européia. 
CAPÍTULO 8 - AS CANÇÕES BRASILEIRAS I (1894)

Nepomuceno retorna ao Rio de Janeiro em junho de 1895. Seu concerto inaugural, sua apresentação à sociedade musical após os longos anos de estudos na Europa, teve lugar no INM em agosto desse mesmo ano:

O concerto, 'verdadeira solenidade para apresentação oficial do artista', no dizer do crítico, seria sua prestação de contas pelos anos que permanecera na Europa às custas da República. Bombardeando os leitores com outras informações a respeito de Nepomuceno e fazendo reiterados convites para sua exibição artística, Rodrigues Barbosa destacava em seus artigos dois aspectos essenciais que conformam o caráter do compositor cearense: sua vinculação à escola alemã e seu patriotismo, simbolizado pela defesa do canto em língua portuguesa. O crítico valorizava o fato de ele ter estudado na Alemanha, 'onde a música não é considerada uma arte recreativa e uma prenda de boa educação, mas uma arte necessária ao homem para elevação do seu espírito e formação do seu caráter [...], onde a música tem a importância e a seriedade das questões sociais'. Ao anunciar o programa do concerto, destacava as canções sobre versos em língua portuguesa, afirmando que Nepomuceno, 'apesar de sua longa residência na Europa, tem um amor imenso à sua pátria e às coisas de sua terra. É assim que ele acredita que a nossa língua é muito musical e tem todas as qualidades para adaptar-se ao canto'. Assim, o crítico criava enorme expectativa sobre a novidade que estava por ser apresentada ao público, adubando o terreno em que Nepomuceno plantaria depois. (PEREIRA, 2007, p. 108).

O programa do longo concerto, que teve lugar no salão do Instituto Nacional de Música em 4 de agosto de 1895, era muito variado. Nepomuceno apresentou-se ao piano e ao órgão, como solista e também acompanhando cantores em uma amostra de sua produção para canto e piano até o momento. Foram apresentadas três canções sobre poemas de Lenau e Drömd Licka, cantadas por sua esposa, Walborg Bang Nepomuceno. Carlos Alves de Carvalho cantou Il flotte dans l'air e duas peças em português, Ora dize-me a verdade e Amote muito (esta última canção foi bisada a pedido do público). Mais adiante, a soprano Camila da Conceição apresentou mais duas canções em português, "reforçando um programa de valorização da nossa língua": Mater dolorosa e Tu és o sol.

A consagração foi imediata. No dia seguinte, toda a imprensa sorria em elogios ao jovem artista. A Notícia dizia que a sala 'regurgitava de povo, que se sentia orgulhoso' pelos artistas que o Instituto apresentava, e saudava a casa de ensino pelo impulso que a presença de Nepomuceno lhe ia dar. (PEREIRA, 2007, p. 109). 
Em carta ao pintor Eliseu Visconti, o próprio Nepomuceno afirmava que as canções em português tinham feito "um sucesso colossal", que ele tinha feito "coisa de arromba", que tinha sido "um sucesso em toda linha".

Tudo no programa apresentado por Nepomuceno aponta para o caráter político da atuação do compositor, visando ocupar espaço na Capital Federal. O objetivo principal e imediato era conquistar o público e a crítica. Só assim podemos entender a gritante ausência das canções sobre textos de Maeterlinck. Mais revelador ainda é o impressionante retrocesso que se observa nessas primeiras canções em português quando comparadas com Oraison, no que à contemporaneidade da linguagem se refere. Nepomuceno estava jogando para o público, e a necessidade de um êxito retumbante se impôs sobre qualquer consideração ou opção estética. Seja por intuição, seja por conselhos de pessoas mais experientes, ele provavelmente sabia que as ousadias vanguardistas das canções de Maeterlinck não seriam bem recebidas pelo conservador público fluminense da época.

Mas antes de examinarmos as canções em português apresentadas no concerto, há a que ficou em manuscrito, obviamente uma primeira tentativa do que Nepomuceno estava preparando ainda em Paris para sua apresentação inaugural. Trata-se de Desterro, sobre texto de Olavo Bilac. O assunto o atraiu, obviamente, já que estava no estrangeiro; a tentação de colocar em música a saudade, fazer uma canção do exílio ainda que metafórico com texto de um poeta contemporâneo renomado é patente e, entretanto, frustrada. Desterro é uma canção brahmsiana, onde saltam à vista os problemas de prosódia e de métrica com que ele se envolve ao ambientar pela primeira vez um texto em português, depois da Ave Maria. Alguns exemplos são o acento no "te" de "Beijo-te" no compasso 6, na primeira sílaba de "sair" no compasso 10, e a divisão silábica de "A-de-us" no compasso 23: 
EXEMPLO 46: A. NePOMUCENO. Desterro, c. 6-11 e c. 23-24
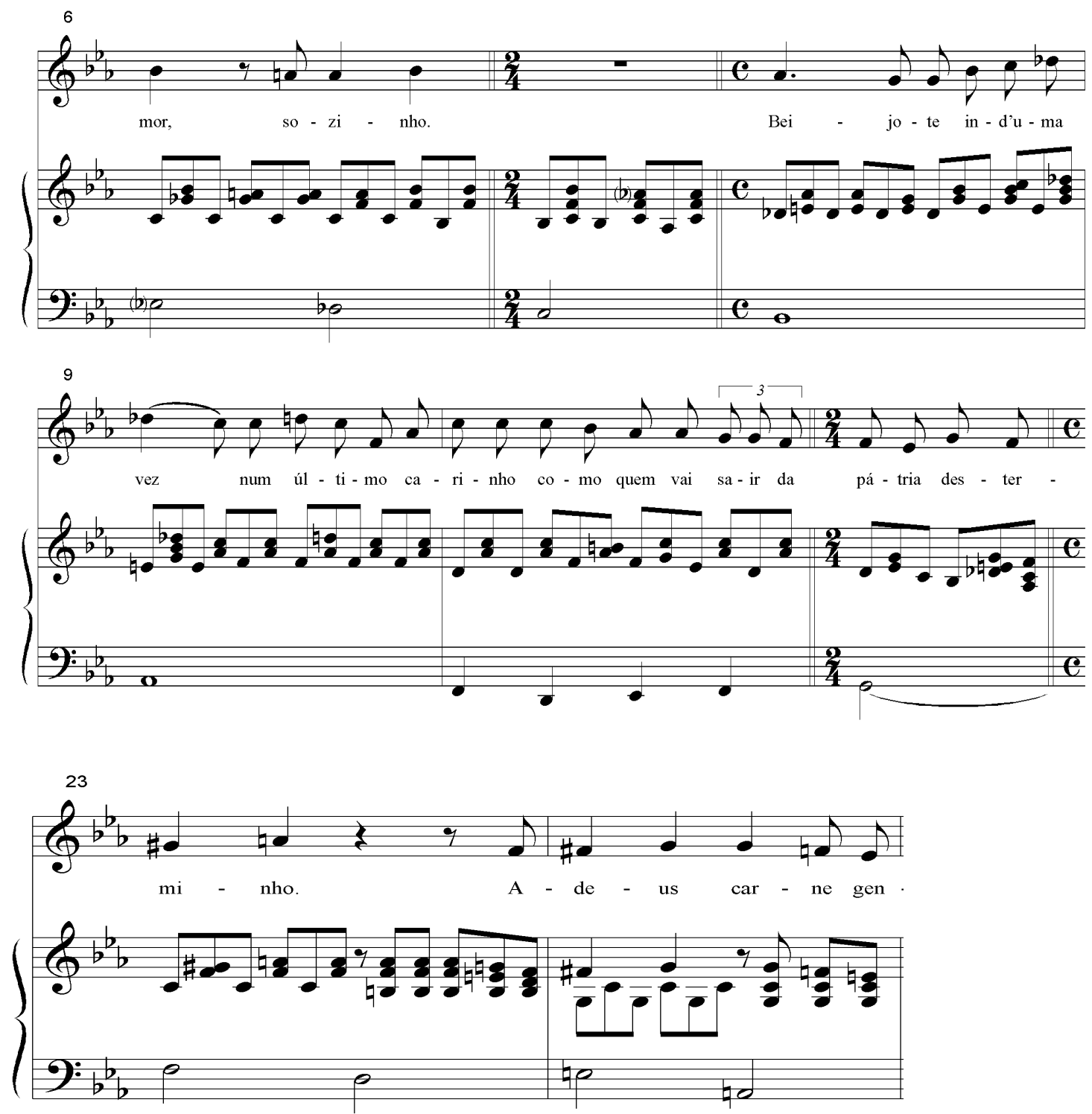

PIGNATARI, Dante (Ed.). Canções para voz e piano. São Paulo: EDUSP, 2004, p. 99 e 100.

Além disso, a necessidade de interpolar compassos anacrúsicos de dois tempos no início de cada estrofe (o compasso da canção é quaternário) e em outros pontos em que o remendo se faz necessário revela o desconforto do compositor com a métrica do poema de Bilac. Cada uma dessas estrofes, sem exceção, começa num ponto diferente do conjunto de compassos de 2 e de quatro tempos inicial (compassos 1-2, 7-8, 13-14, 33-34). Além disso, a canção é longa, e sua forma pouco clara. E ainda é preciso levar em conta o final sombrio: os versos Que esse outro amor há de amargar-me tanto / como o pão que se come entre estranhos / no exílio, / amassado com fel, embebido de pranto não eram propícios para escrever música que arrebatasse o público. Essa honra ficou reservada para Amo-te muito, op. 
$12 \mathrm{n}^{\circ} 2$, sobre versos de João de Deus, a única peça bisada na apresentação de 4 de agosto de 1895:

EXEMPLO 47: A. NePOMUCENO. Amo-te muito, c. 1-9
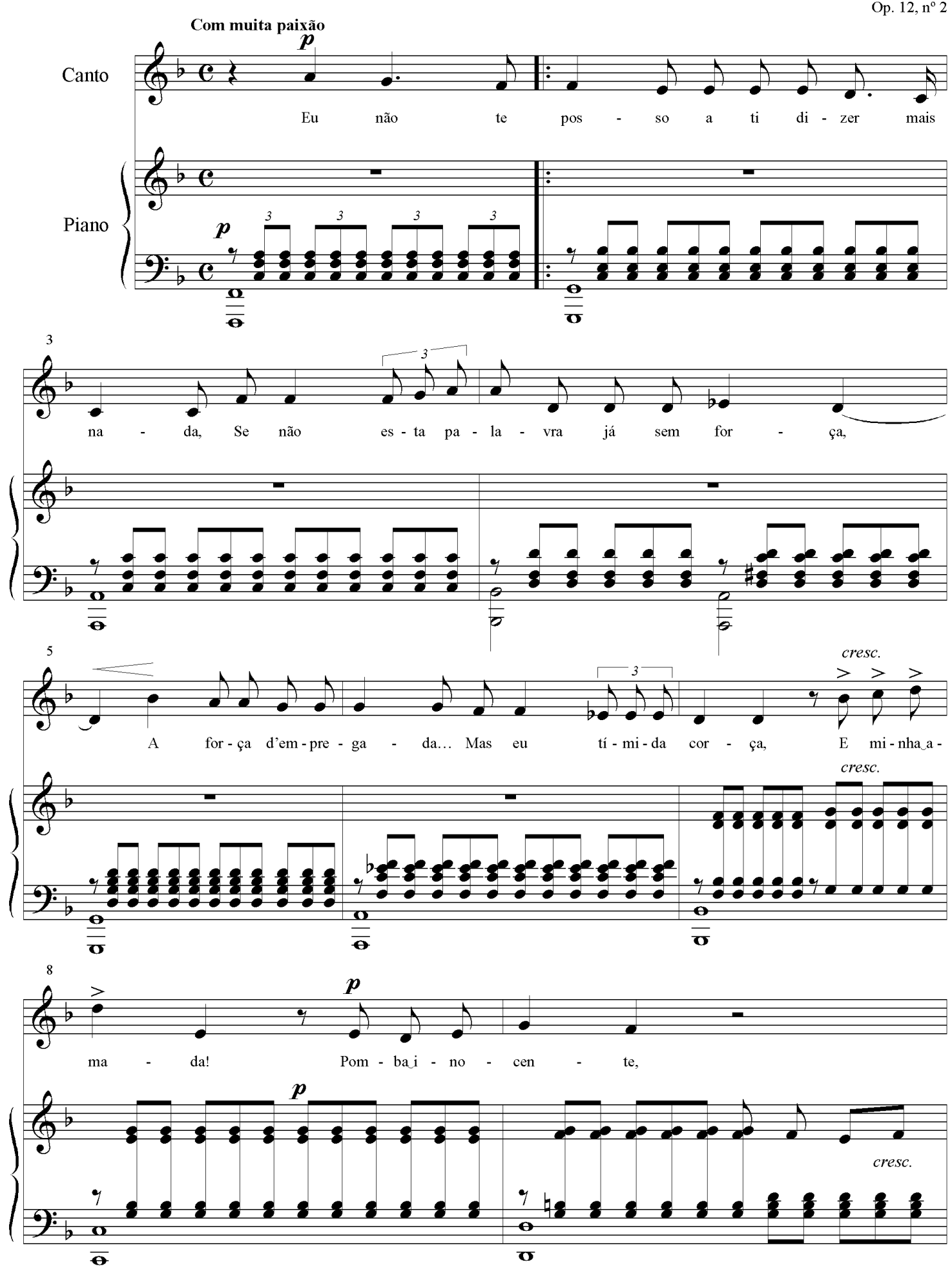

PIGNATARI, Dante (Ed.). Canções para voz e piano. São Paulo: EDUSP, 2004, p. 106. 
Nepomuceno aproveitou várias idéias de Desterro para Amo-te muito, a começar pelo motivo melódico inicial e a subdivisão binária da melodia cantada contra a subdivisão ternária do acompanhamento.

Durante a polêmica travada através da imprensa fluminense entre Nepomuceno e o crítico Oscar Guanabarino em outubro e novembro de 1895, este acusou o cearense de ter plagiado Schubert. Em resposta, Nepomuceno afirma ironicamente ter plagiado também Mendelssohn e Wagner (PEREIRA, 2007, p. 115). Esta referência a Wagner pode referir-se à já mencionada citação d'A Valquíria em Herbst, também de Lenau. Já em Amo-te muito, é precisamente a música de Mendelssohn que nos vem de imediato à mente, especialmente na linguagem harmônica solar, a melodia fácil, a aparente inevitabilidade na construção do ponto culminante e da acumulação de tensão para obter o efeito de arrebatamento (a indicação de caráter é Com muita paixão), até mesmo o tratamento dado ao ritmo e à melodia. Um modelo possível é a Canção sem palavras op. 53 nº 2 do compositor alemão:

EXEMPLO 48: F. MENDELSSOHN. Canção sem palavras op. $53 n^{o}$ 2, c. 1-9
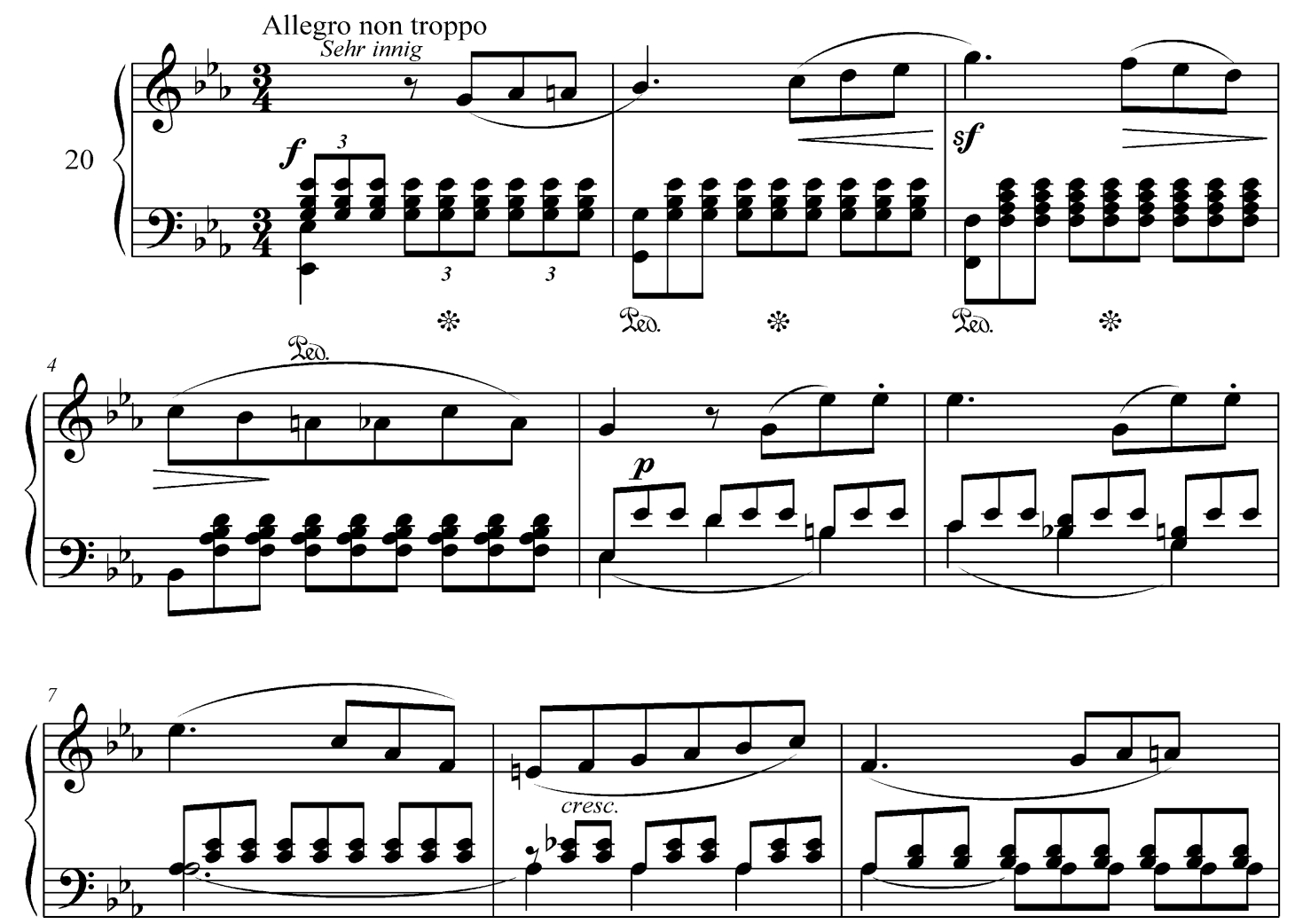

ELVERS, R. e HERTTRICH, E. (Ed.). Lieder ohne Worte. Munique: Henle Verlag, 1981, p. 64. 
Ainda que apresente duas pequenas imperfeições prosódicas, daquelas apontadas por Mário de Andrade em Os compositores e a língua nacional (ANDRADE, 1991, p. 32-94), em ambos os casos vogais fechadas cantadas em notas agudas (mim em um fá no compasso 20 e muito em um sol no compasso 23, este o ponto culminante da parte vocal), a adaptação da música ao texto em Amo-te muito é de uma naturalidade notável, apesar do caráter mendelssohniano e portanto germânico daquela.

Em contraste com a melodiosidade de Amo-te muito, a primeira do par de canções que compõe o opus 12 de Nepomuceno, Ora dize-me a verdade, é um experimento de adaptação do recitativo wagneriano a um texto de poeta brasileiro, aqui novamente João de Deus. No mesmo artigo mencionado acima, em que acusava nosso compositor de plágio, Guanabarino também apontou um erro de prosódia cometido por Nepomuceno (PEREIRA, 2007, p. 115). O crítico certamente se refere a um erro grosseiro no compasso 10 de Ora dize-me a verdade, tão grosseiro que mais parece uma distração do compositor, já que de fácil correção, coisa que de resto os cantores fazem de maneira quase instintiva quando interpretam esta canção. O que acontece aqui é que a primeira sílaba de sentiste, átona, cai no primeiro tempo do compasso, ou seja, num tempo forte, acentuado:

EXEMPLO 49: A. NEPOMUCENO. Ora dize-me a verdade, c. 8-11

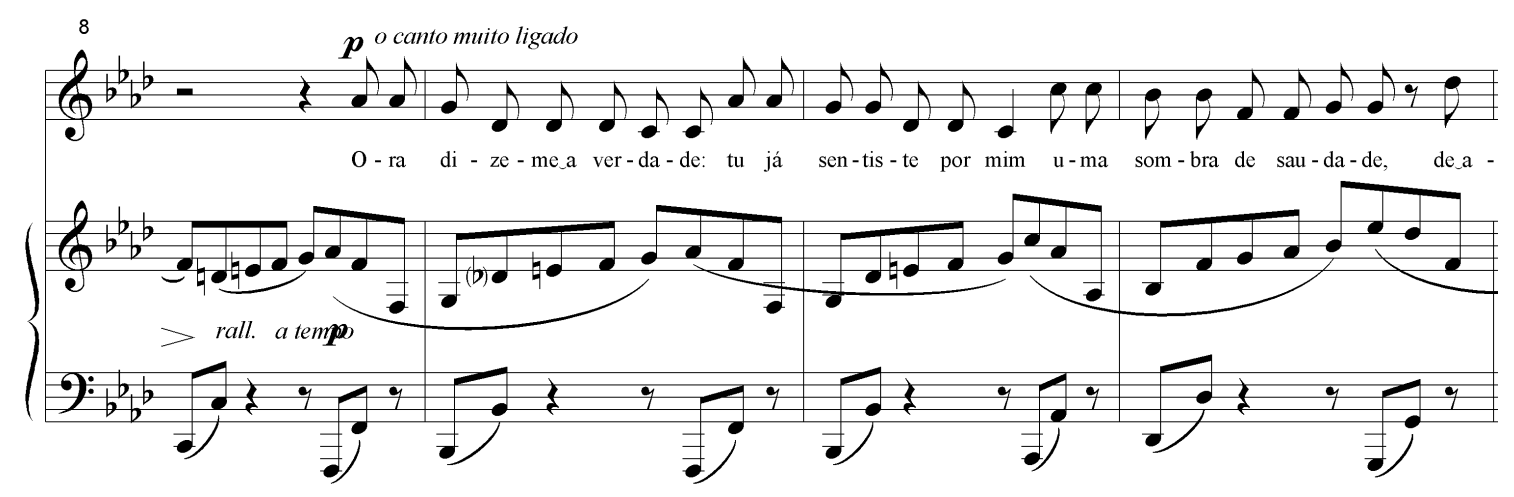

PIGNATARI, Dante (Ed.). Canções para voz e piano. São Paulo: EDUSP, 2004, p. 103.

Ora dize-me a verdade é uma primeira tentativa bem sucedida de nacionalização da música européia, germânica neste caso, por meio do idioma. A canção inicia-se com uma longa introdução instrumental constituída por uma figuração circular que começa com um salto descendente de oitava e retorna ao ponto inicial ascendendo com um salto de quinta diminuta e graus diatônicos sobre um acorde diminuto de dominante. Essa figura se apoia em oitavas quebradas no baixo que tem acentuada alternadamente ora a primeira, ora a segunda 
colcheia. O resultado é um movimento contínuo ao mesmo tempo inquieto e melancólico de grande autonomia; a parte instrumental desta canção se sustenta perfeita e integralmente sem a parte vocal, constituindo-se em um autêntico Prelúdio para piano:

EXEMPLO 50: A. NePOMUCENO. Ora dize-me a verdade, c. 1-8

Op. $12, \mathrm{n}^{\circ} 1$

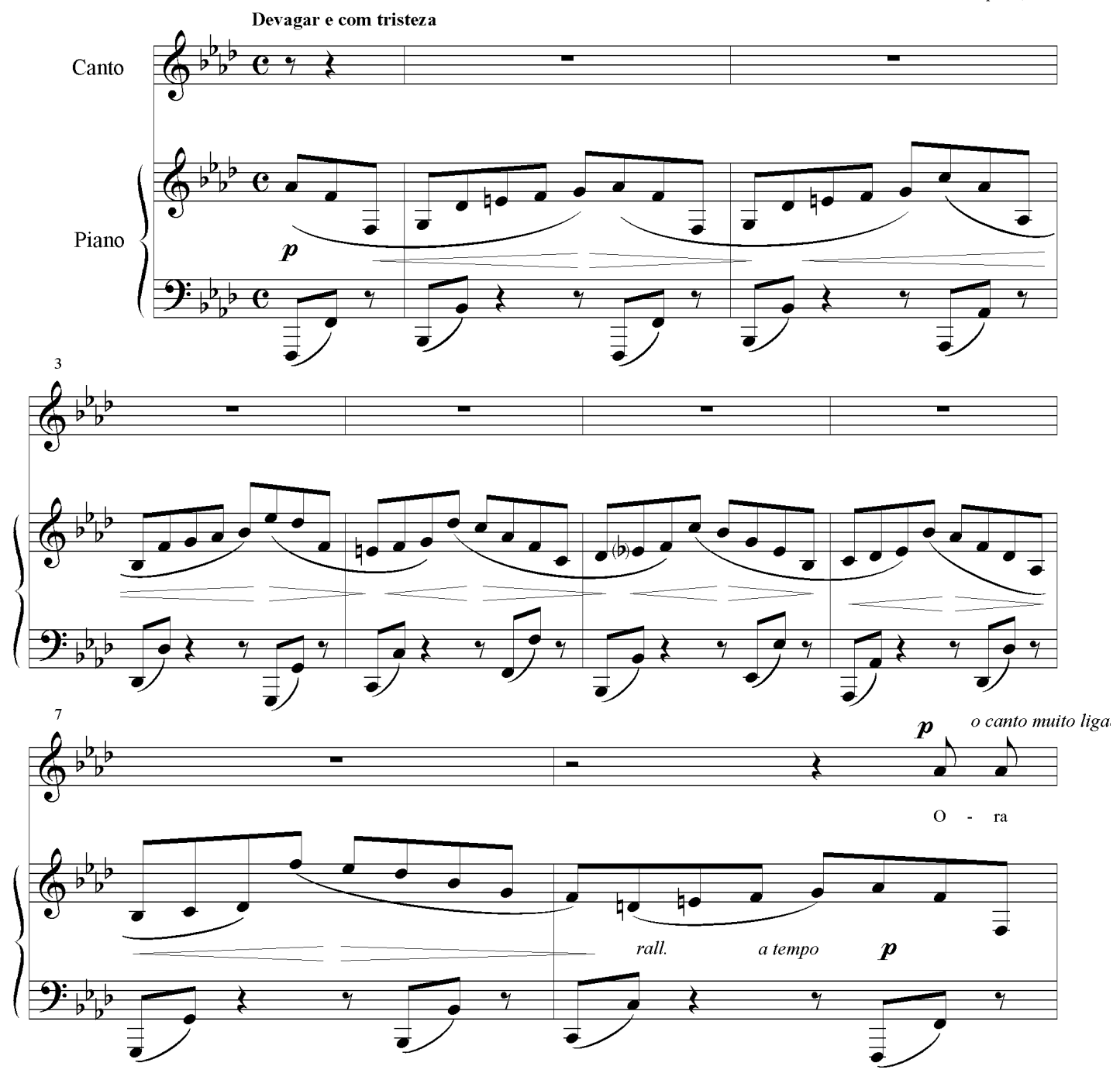

PIGNATARI, Dante (Ed.). Canções para voz e piano. São Paulo: EDUSP, 2004, p. 103.

Nepomuceno se inspira no arioso wagneriano para compor a parte vocal da canção, um quasi parlato construído sobre intervalos bem pouco melodiosos: $2^{\mathrm{a}}$ menor e $4^{\mathrm{a}}$ aumentada na primeira parte do primeiro período, ao final deste um salto de sétima diminuta: 

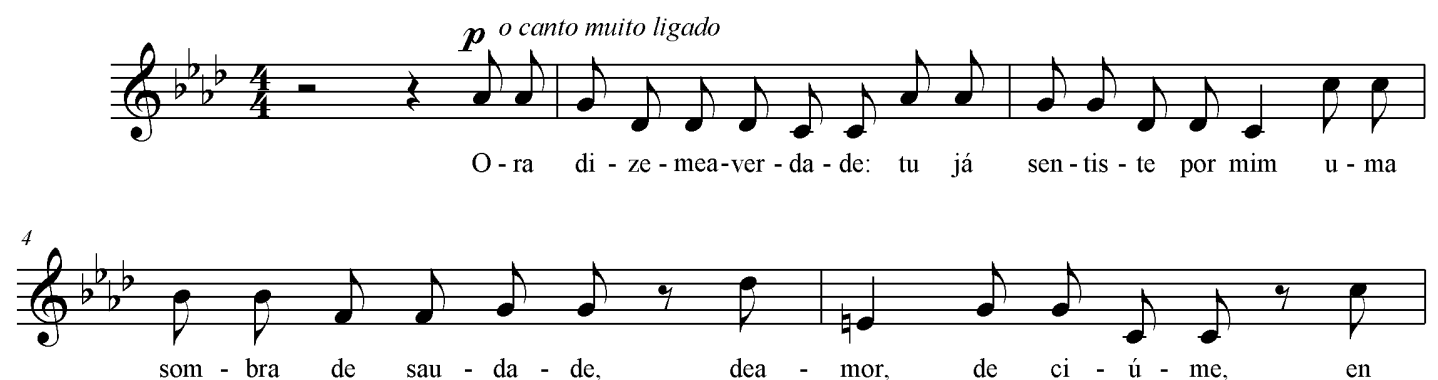

PIGNATARI, Dante (Ed.). Canções para voz e piano. São Paulo: EDUSP, 2004, p. 99.

Esse recitativo se superpõe à figuração do acompanhamento, num contraponto de vozes em que a parte vocal, na verdade o esqueleto da melodia instrumental, está sempre defasada desta última num desencontro contínuo. A parte instrumental, que representa aquela a quem o poeta se dirige, prossegue inabalável em seu movimento, sem se deixar perturbar pela insistência da voz que a persegue querendo saber se ela sente algo por si. Ao transformar o texto em recitativo, ou seja ao transformar fala em canto, o compositor amplia os gestos vocais e transforma a expressão verbal em expressão musical. Ao escutarmos a parte cantada de Ora dize-me a verdade, nos damos conta de que aí reside a chave de como Nepomuceno pretende que o idioma flexione a música: embora inspirada no recitativo wagneriano, os contornos rítmico-melódicos desenhados nesta canção em nada lembram o compositor alemão, pois derivam das palavras que revestem; no caso, os versos em português de João de Deus, certamente recitados e cantados com sotaque nacional. É isso o que faz a musicalidade desse recitativo ser original e, apesar da ausência de qualquer vestígio de folclore, genuína e inegavelmente brasileira.

O outro par de canções em português apresentado neste concerto inaugural, Op. $14 \mathrm{n}^{\circ} \mathrm{s}$ 1 e 2, reproduzem o esquema das canções Op. 12, inclusive na relação contrastante que têm entre si em relação ao andamento, lento / animado, ao caráter, triste / apaixonado, e às tonalidades, fá menor / fá maior no op. 12, fá \# menor / sol bemol maior no Op. $14^{22}$. A primeira canção do Op. 14, Mater dolorosa, ambienta um soneto de Gonçalves Crespo. É uma cena crepuscular em que uma mulher, imóvel, observa da praia desaparecer no horizonte o

\footnotetext{
${ }^{22}$ No manuscrito autógrafo, Tu és o sol! está em sol bemol maior. No entanto, ao ser publicada a canção foi transposta para sol maior, tonalidade de leitura mais "fácil" para pianistas amadores. Exatamente a mesma coisa, pela mesma razão e com as mesmas tonalidades, ocorreu com o Impromptu Op. $90 \mathrm{n}^{\circ} 3$ de Schubert.
} 
navio que leva embora seu filho enquanto o sol se põe e a lua surge. Nepomuceno utiliza a forma-canção, ABA, de resto a forma de três das quatro canções em português apresentadas nessa ocasião (a exceção é Amo-te muito!). Na primeira parte, em que a cena é descrita, o acompanhamento do piano é um ondular manso formado por acordes na mão direita e oitavas no baixo; é o cenário do mar calmo visto pelos olhos da mãe que chora:

EXEMPLO 52: A. NEPOMUCENO. Mater dolorosa, c. 1-4

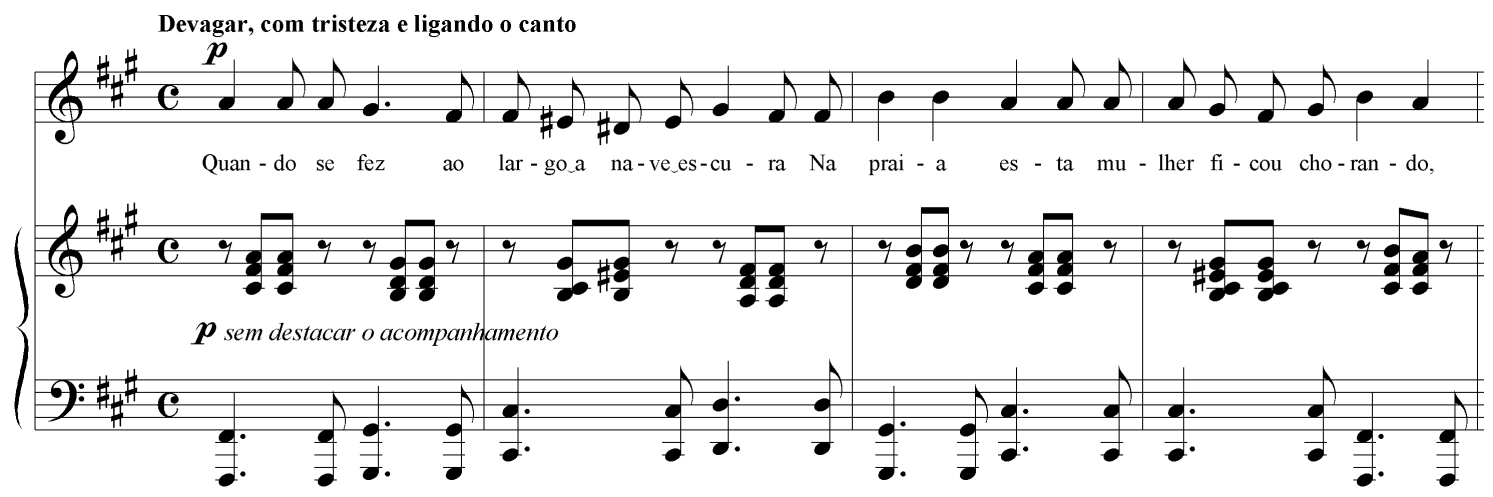

PIGNATARI, Dante (Ed.). Canções para voz e piano. São Paulo: EDUSP, 2004, p. 109.

A segunda quadra do poema descreve a paisagem, as aves marinhas voando em círculos, e o jogo de luzes criado pelo sol que desaparece no mar e a lua que sobre ele se eleva. O acompanhamento reflete a mudança de foco transformando os acordes em arpejos descendentes e as oitavas do baixo em notas únicas, o que confere movimento e leveza à música:

EXEMPLO 53: A. NEPOMUCENO. Mater dolorosa, c. 9-12

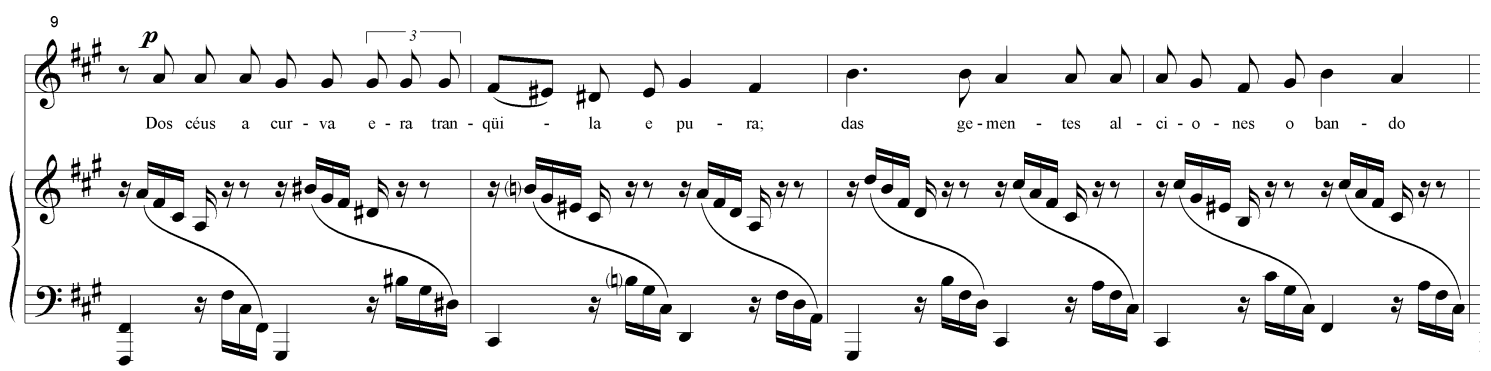

PIGNATARI, Dante (Ed.). Canções para voz e piano. São Paulo: EDUSP, 2004, p. 109. 
À medida em que a descrição da paisagem se torna mais dramática, também os arpejos ganham amplitude e passam a ser descendentes e ascendentes, como se as vagas fossem aumentando de tamanho à medida em que o navio prossegue em sua jornada inexorável mar adentro:

EXEMPLO 54: A. NePOMUCENO. Mater dolorosa, c. 17-20

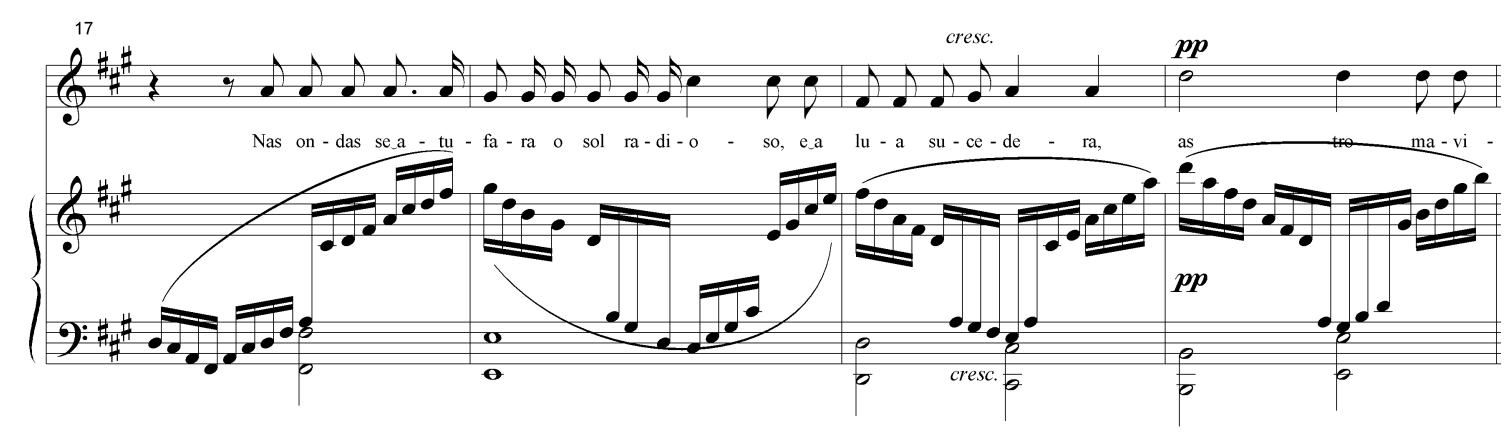

PIGNATARI, Dante (Ed.). Canções para voz e piano. São Paulo: EDUSP, 2004, p. 110.

A terceira parte da canção nos leva de volta à praia, à mãe em lágrimas com a vista perdida no mar e ao acompanhamento de acordes e oitavas, às ondas mansas e tristes que chegam vagarosamente à praia. $\mathrm{O}$ arioso vocal volta a ser embalado pelo ritmo ondulante do acompanhamento e a ele está perfeitamente integrado. Assim como em Ora dize-me a verdade, Mater dolorosa é uma segunda instância de adaptação da música européia à língua pátria: os contornos rítmico-melódicos não são impostos às palavras, mas acompanham os que são inerentes aos versos, buscando extrair destes sua musicalidade natural, por assim dizer.

Contrastando com a cena crepuscular e melancólica do poema de Gonçalves Crespo, a segunda canção do Op. 14 é Tu és o sol!, texto de um conterrâneo de Nepomuceno, Juvenal Galeno. O que de imediato chama a atenção nesta canção são os extremos de virtuosismo pianístico a que o compositor recorre para recriar musicalmente a luminosidade e o calor arrebatado evocados pelo poema (a indicação de caráter é com entusiasmo). Poucas vezes o acompanhamento de uma canção terá feito tais exigências técnicas ao intérprete. Tanto isso é assim que o próprio autor providenciou uma versão facilitada da parte do piano, já que a versão original estaria ao alcance de apenas uns poucos profissionais que tivessem o domínio técnico exigido pela peça: 
EXEMPLO 55: A. NePOMUCENO. Tu és o sol!, c. 1-5

Op. $14, n^{\circ} 2$

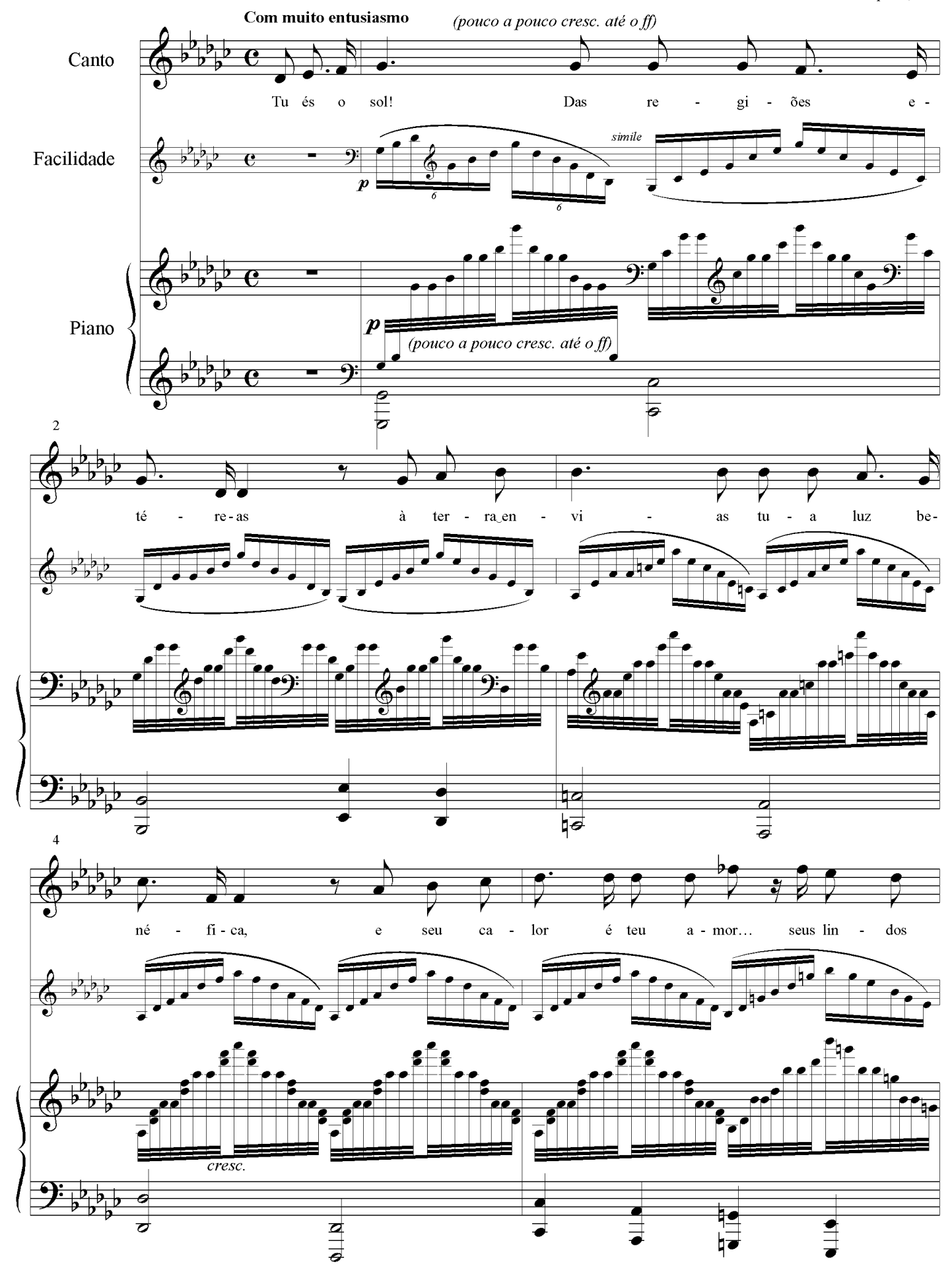

PIGNATARI, Dante (Ed.). Canções para voz e piano. São Paulo: EDUSP, 2004, p. 112.

De fato, Nepomuceno combina aqui dois estudos para piano de Chopin, as oitavas no baixo do Op. $10 \mathrm{n}^{\circ} 1$ : 
EXEMPLO 56: F. CHOPIN. Estudo Op. $10 n^{o}$ 1, c. 1-6
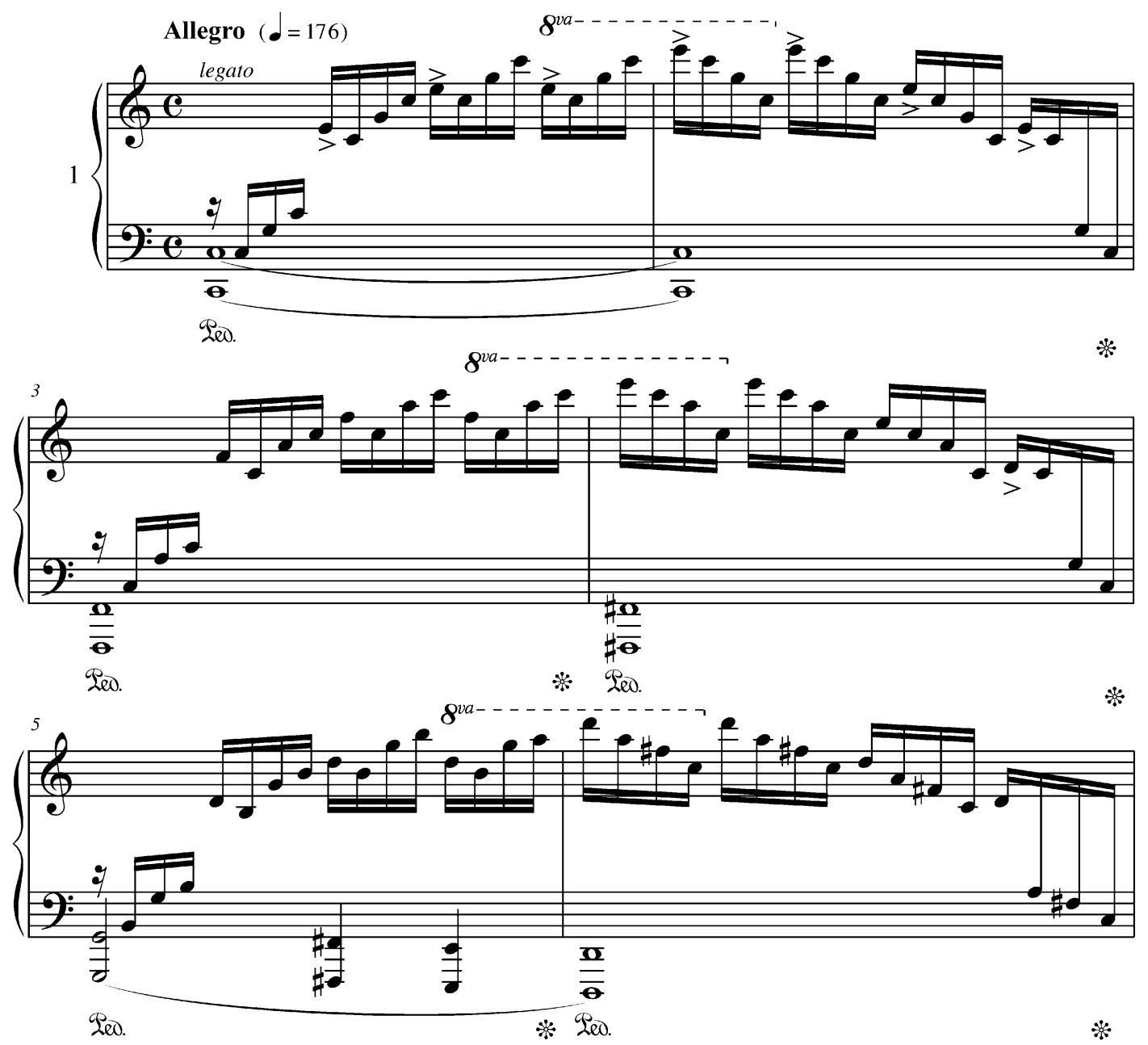

PADEREWSKI, I. (Ed.). Estudos para piano. Cracóvia: Polish Music Publications, 1949, p. 7. 
... e a figuração arpejada do Op. $25 \mathrm{n}^{\circ} 12$ :

EXEMPLO 57: F. CHOPIN. Estudo Op. $25 n^{\circ}$ 12, c. 1-6
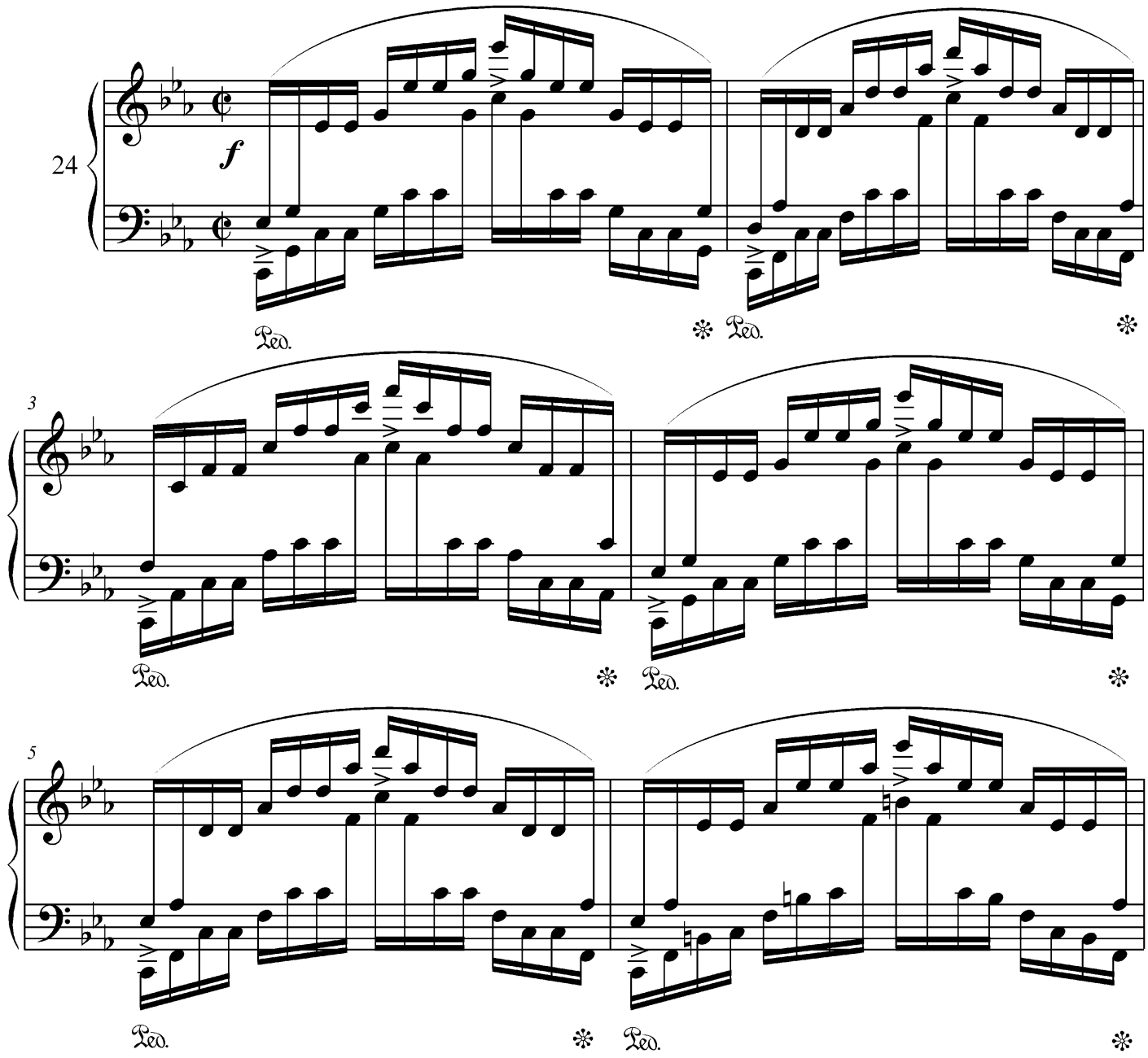

PADEREWSKI, I. (Ed.). Estudos para piano. Cracóvia: Polish Music Publications, 1949, p. 118.

A agógica de Tu és o sol! é um bom exemplo de como Nepomuceno concebe o elemento rítmico-melódico da parte vocal de suas canções a partir da acentuação e música do poema que está ambientando: a acentuação marcada das palavras, com proparoxítonas encerrando boa parte dos versos do poema, leva o compositor a iniciar cada compasso com uma nota pontuada sobre uma sílaba fortemente tônica. A célula rítmica utilizada para resolver as proparoxítonas é 10 . e é aplicada sobre as palavras e-té-re-as, be-né-fi-ca, $v i ́-v i-d o s$ e né-vo-a na primeira parte da canção. Na segunda parte há uma suspensão do movimento, sendo a parte vocal dobrada pela mão direita do piano e acompanhada por trêmolos no baixo: 
EXEMPLO 58: A. NEPOMUCENO. Tu és o sol!, c. 21-29
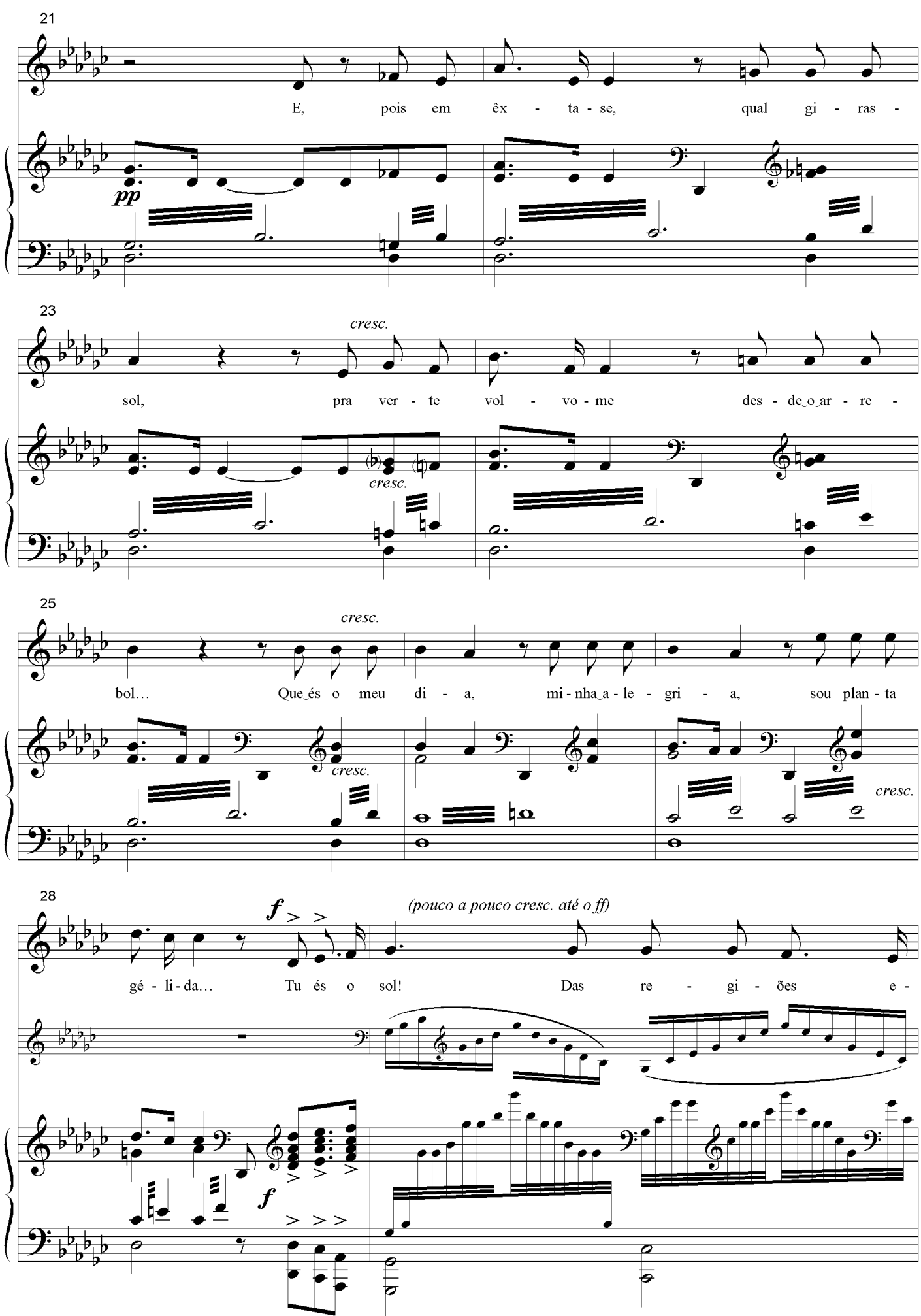

PIGNATARI, Dante (Ed.). Canções para voz e piano. São Paulo: EDUSP, 2004, p. 115.

Essa suspensão do movimento gera ainda uma acumulação de tensão, mais acentuada à medida em que a seção se aproxima da reexposição da primeira parte, o que coincide 
também com o retorno das proparoxítonas e da célula rítmica que as acompanha: êx-ta-se, vol-vo-me, gé-li-da, e conduz com mais ênfase ainda à verdadeira explosão de fogos virtuosísticos que é a primeira parte da canção.

As relações entre as canções do Op. 12 e também as do Op. 14 são mais profundas que o contraste de modos e de caráter. Há também relações estruturais, especialmente entre os perfis melódicos e o registro por eles percorrido. No Op. 12, a parte cantada de Ora dize-me a verdade tem um traçado descendente que vai de lá bemol a dó, o mesmo percorrido pela melodia de Amo-te muito!, sendo o registro de sexta desta última maior, correspondendo aos modos contrastantes das duas canções:

EXEMPLO 59: A. NePOMUCENO. Ora dize-me a verdade, c. 1-2, e Amo-te muito, c. 1-2
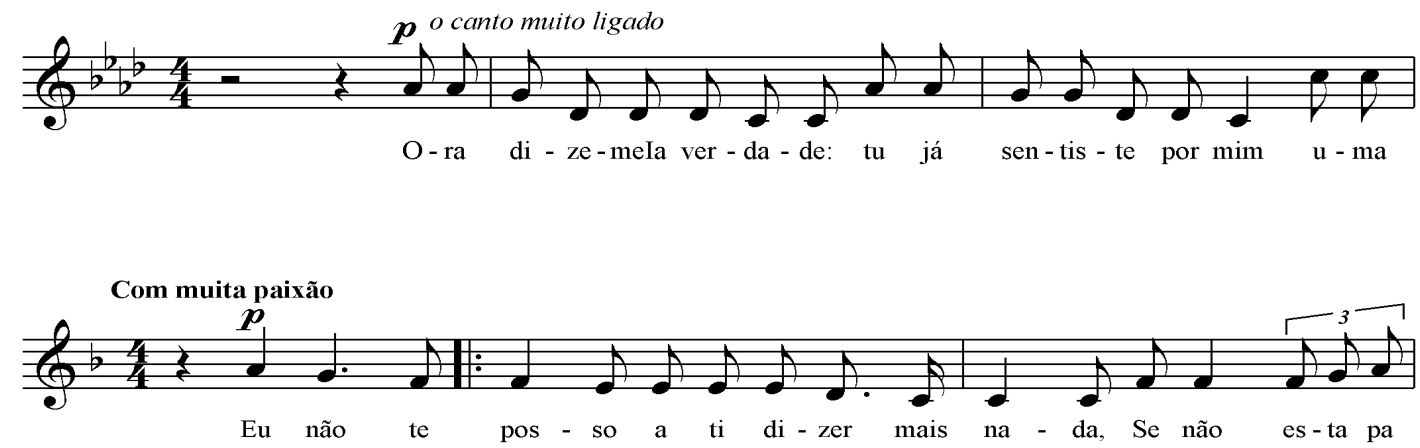

PIGNATARI, Dante (Ed.). Canções para voz e piano. São Paulo: EDUSP, 2004, p. 103 e 106 respectivamente.

Os perfis das canções Op. 14 também exibem desenhos semelhantes:

EXEMPLO 60: A. NePOMUCENO. Tu és o sol!, c. 1-2, e Mater dolorosa, c. 1-2
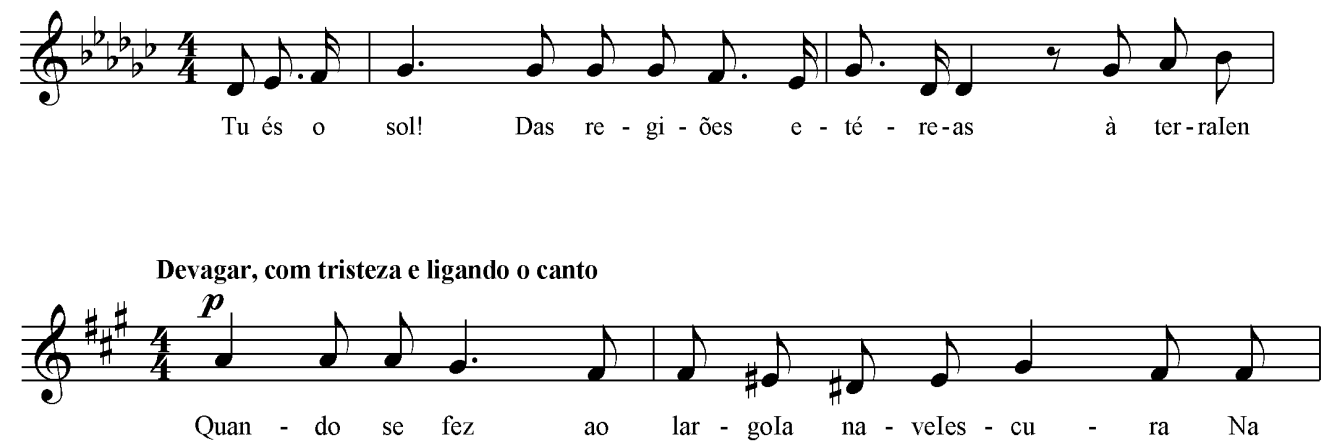

PIGNATARI, Dante (Ed.). Canções para voz e piano. São Paulo: EDUSP, 2004, p. 109 e 112 respectivamente. 
Estas primeiras canções em português mostram claramente terem sido as peças que integram cada número de opus concebidas como um par. Essa concepção das canções em pares contrastantes evidentemente atraía o compositor: canções agrupadas em pares sob o mesmo número de opus se repetem nada menos que doze vezes na obra de Nepomuceno, e em pelo menos outros três casos de canções sem número de opus (nenhuma canção composta após 1904 os tem), o emparelhamento é evidente. Refiro-me a Candura e Flores, adaptações para o português de textos de Rabindranath Tagore, Olha-me! e Numa concha, de Olavo Bilac, e Canção da Ausência e Luz e névoa, de Hermes Fontes. Somada à dúzia de pares com número de opus mencionada acima, um caso de agrupamento de três canções (Op. 21), mais o ciclo Lenau, as duas canções de Maeterlinck e as quatro de Henri Piazza, além do ciclo Le miracle de la semence, com cinco números, concluímos que as peças isoladas são exceção no cancioneiro de Nepomuceno ${ }^{23}$.

\footnotetext{
${ }^{23}$ Há ainda um provável par de canções em italiano: uma outra canção com texto de Aleardi, Rispondi, que está extraviada, provavelmente fazia par com Perchè?.
} 
Segundo o CG, o opus seguinte do cancioneiro de Nepomuceno, o de número 17, é de 1894, tendo sido as duas canções que o integram compostas, portanto, ainda durante a temporada parisina do compositor. Em Medroso de amor, Op. $17 \mathrm{n}^{\mathrm{o}}$ 1, sobre texto de Juvenal Galeno, encontramos pela primeira vez um elemento retirado do universo popular, no caso o ritmo sincopado característico da música popular urbana da época, presente em gêneros como o maxixe, o tango brasileiro e o choro.

\begin{abstract}
A essa altura (1892) o maxixe já estava decantado na cultura musical nacional, o que vale dizer, mais especificamente, que a síncopa característica [...] já era a forma rítmica recorrente da música de dança do período. Portanto, fosse nos corta-jacas de Chiquinha Gonzaga, nos choros de Anacleto de Medeiros ou nos tangos de Nazareth, dos "cabeças-de-porco" ao Palácio das Águias, ouvia-se e dançava-se a síncopa cristalizada como gênero em todos os cantos do Rio de Janeiro [...] (MACHADO, 2007, p. 98).
\end{abstract}

Não era incomum que algumas dessas peças sincopadas, fundamentalmente danças instrumentais, recebessem letra e se transformassem assim em canção. Um caso exemplar é o tango Brejeiro, de Nazareth, que ganhou letra a posteriori de Catulo da Paixão Cearense. Em uma entrevista concedida em 1924, o próprio compositor afirmava que, trinta anos após ter sido composto, todo o Brasil ainda cantava Brejeiro (MACHADO, 2007, p. 158). Nepomuceno certamente tinha familiaridade com essa música feita de sacolejos e requebros, que aos poucos ia invadindo os salões e fazia dançar todas as classes sociais da Capital Federal, e por ela nutria no mínimo alguma simpatia, como demonstram os convites feitos justamente a Catulo da Paixão Cearense e a Ernesto Nazareth para que participassem das apresentações musicais da Exposição Nacional realizada em 1908 (ver p. 29).

A forma de Medroso de amor é estrófica, rara em nosso compositor e que nele é quase sempre um sinal da proximidade da canção com o universo folclórico e/ou popular. A música é repetida três vezes, uma para cada estrofe do poema. As pequenas variações rítmicas que aparecem na parte vocal se devem à necessidade de acomodar um número de sílabas diferente, caso dos compassos 5-6, 20-21 e 35-36, ou jogam ritmicamente com a síncopa do acompanhamento (compassos 8 e 25). A parte do piano é repetida três vezes sem qualquer alteração. 
Na primeira parte da canção, o acompanhamento é um ostinato em que o baixo, a voz intermediária e as terças na mão direita se movem em contratempo por segundas menores e criam um contraponto cromático bastante complexo e engenhoso que determina as inflexões da linha vocal. Esta constitui uma quarta voz contrapontística que ganha independência ao refletir com métrica diferente os diversos gestos melódicos desenhados pelas vozes do piano. Os quatro fragmentos melódicos que compõem a parte vocal desta primeira parte da canção começam todos em tempos fracos do compasso, e terminam com uma appoggiatura, que também prolonga a linha até um tempo fraco e é um reflexo da voz instrumental intermediária (ver exemplo abaixo). Esta é constituída de appoggiature que acentuam o terceiro tempo do compasso quaternário e estão em contratempo com as terças da mão direita. O resultado é uma hábil ocultação do ritmo sincopado que somente se revela na segunda parte da música. $\mathrm{O}$ contratempo em andamento rápido (a indicação é Presto) imprime o caráter de ansiedade inquieta pretendido pelo compositor, enquanto o aspecto cromático e fragmentado da parte vocal dão o tom urgente e queixoso (a indicação de caráter para a voz é com insistência e ternura) que o título da canção inspira:

EXEMPLO 61: A. NePOMUCENO. Medroso de amor, c. 1-7
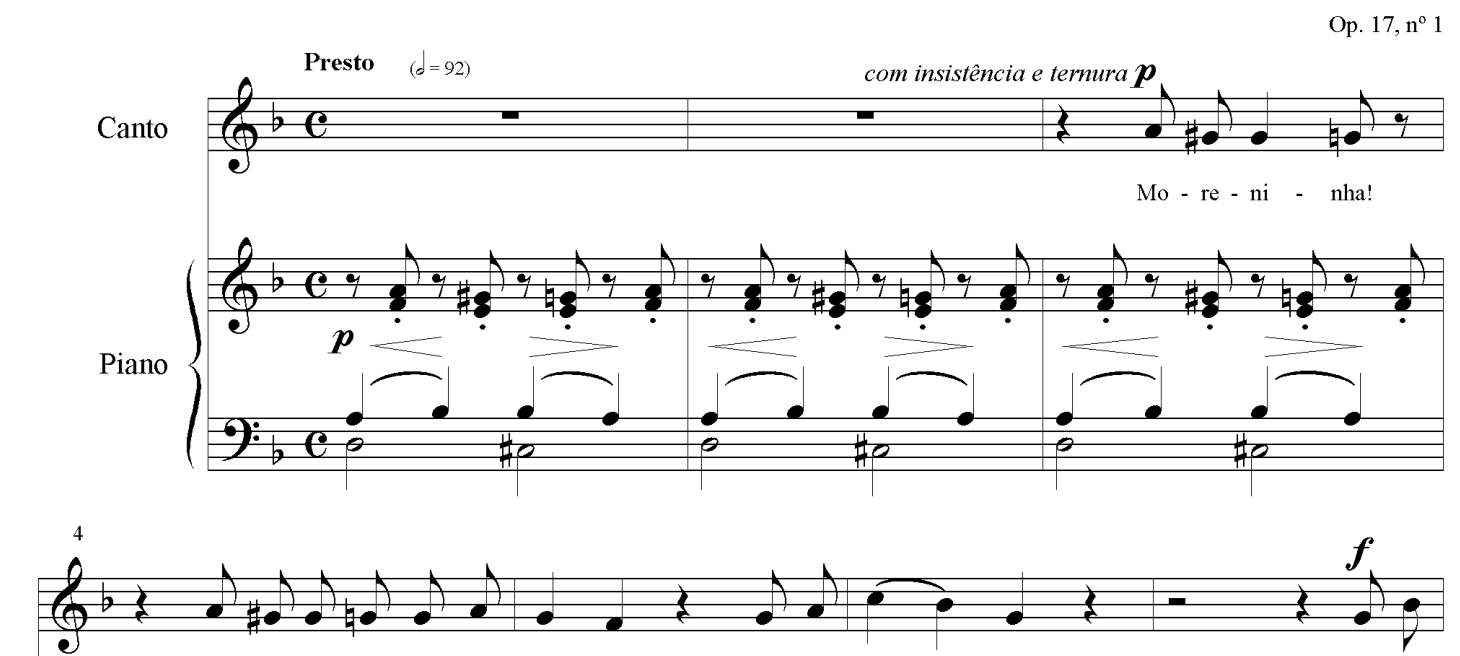

não sor - ri - as com mei - gui - ce... com ter - nu

não sor -

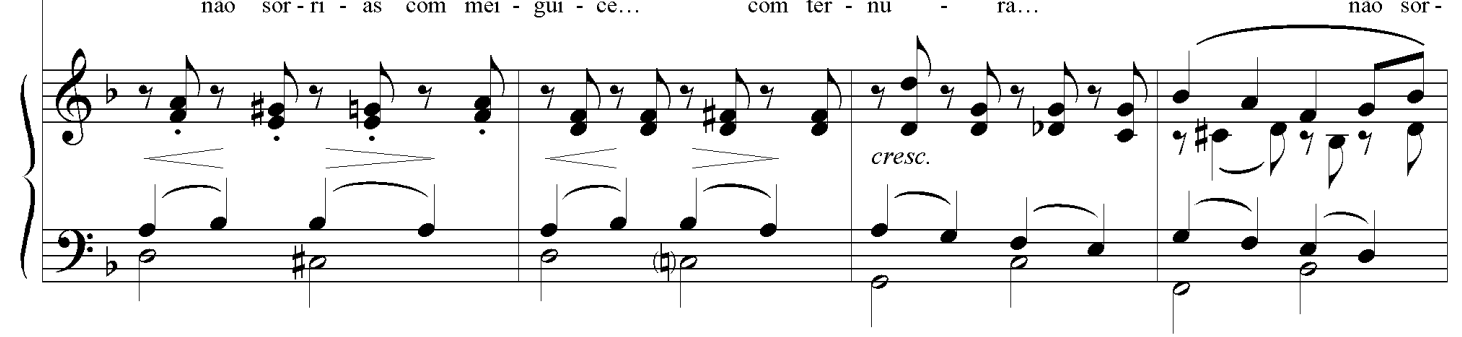

PIGNATARI, Dante (Ed.). Canções para voz e piano. São Paulo: EDUSP, 2004, p. 118. 
A voz na primeira parte de Medroso de amor é uma primeira tentativa de criar o que poderíamos chamar de um recitativo caboclo, incorporando à linha vocal aspectos rítmicos e melódicos da música popular nacional da época. $\mathrm{O}$ acompanhamento é bastante complexo em si mesmo, e a maneira como se relaciona com a voz acrescenta ainda maior complexidade à música quando a analisamos em detalhe, mas nada disso transparece na audição da canção, que flui com uma naturalidade perfeitamente brasileira.

Não fosse o cuidadoso e elaborado artesanato revelado pela análise, creríamos estar ouvindo uma peça do repertório popular da época. A canção se torna de fato quase isso na segunda parte, quando uma simplificação drástica do contraponto une a voz intermediária e as terças da mão direita para formar acordes sincopados sobre um baixo harmônico, um tipo de acompanhamento típico da música popular urbana encontrada no Rio de Janeiro da belle époque. Ao mesmo tempo, a melodia vocal perde o caráter fragmentado e se deixa contaminar pelo ritmo sincopado: todas as frases começam com síncopas. Além disso, o cromatismo cede lugar a um percurso melódico essencialmente diatônico, e a justaposição da tonalidade principal, ré menor, com a relativa maior (esta na primeira frase desta segunda parte, a outra na segunda), reforça o caráter agridoce herdado da modinha, menos evidente na primeira parte da canção devido aos movimentos melódicos cromáticos que lá predominam. Ocorre nessa segunda parte um desvelamento em que a música agora mostra de maneira explícita e inequívoca sua derivação direta da música popular.

EXEMPLO 62: A. NEPOMUCENO. Medroso de amor, c. 10-15

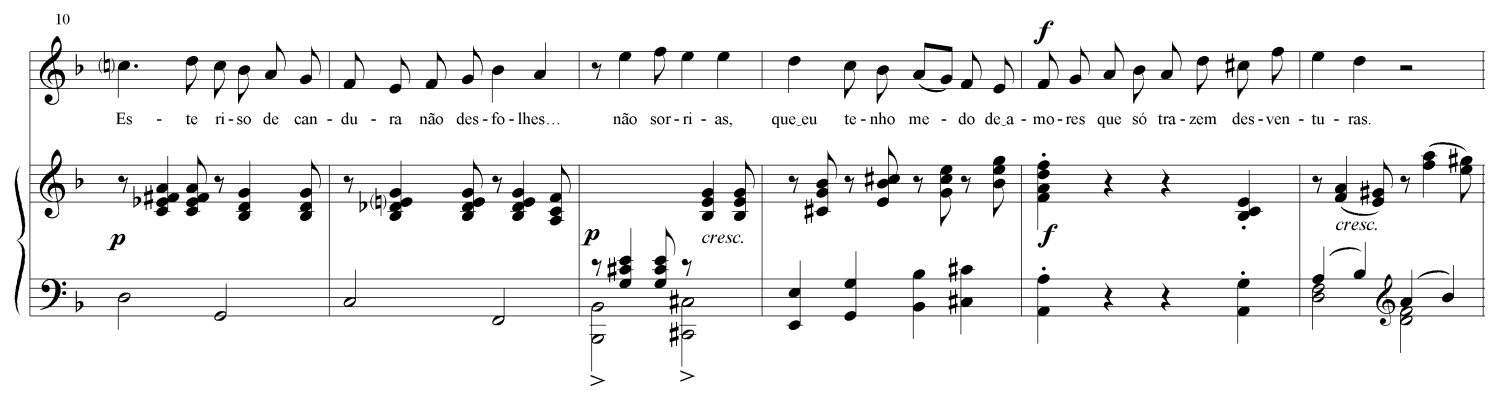

PIGNATARI, Dante (Ed.). Canções para voz e piano. São Paulo: EDUSP, 2004, p. 118.

A passagem seguinte, do Ensaio sobre a música brasileira de Mário de Andrade, parece quase descrever a relação da melodia vocal de Medroso de amor com o acompanhamento, primeiro na primeira parte, em que a voz não acompanha o ritmo sincopado, e depois na segunda, em que a síncopa é incorporada pelo canto, e mostra a 
profunda compreensão que Nepomuceno já tinha da música popular urbana brasileira na última década do século XIX:

\begin{abstract}
O cantador aceita a melodia rítmica justa sob todos os pontos-de-vista a que a gente chama de Tempo, mas despreza a medida injusta (puro preconceito teórico as mais das vezes) chamada compasso. E pela adição de tempos, talequal fizeram os gregos na maravilhosa criação rítmica deles, e não por subdivisão que nem fizeram os europeus ocidentais com o compasso, o cantador vai seguindo livremente, inventando movimentos essencialmente melódicos (alguns antiprosódicos até) sem nenhum dos elementos dinamogênicos da síncopa e só aparentemente sincopados, até que num certo ponto (no geral fim da estrofe ou refrão) coincide de novo com o metro (no sentido grego da palavra) que pra ele não provém de uma teorização mas é de essência puramente fisiológica. Coreográfica até. São movimentos livres determinados pela fadiga. São movimentos livres desenvolvidos da fadiga. São movimentos livres específicos da moleza da prosódia brasileira. São movimentos livres não acentuados. São movimentos livres acentuados por fantasia musical, virtuosidade pura, ou por precisão prosódica. Nada têm com o conceito tradicional da síncopa e com o efeito contratempado dela. Criam um compromisso sutil entre o recitativo e o canto estrófico. São movimentos livres que tornaram-se específicos da música nacional. (ANDRADE, 1962, p. 36).
\end{abstract}

Ainda no Ensaio, Mário descreve alguns gestos melódicos que identifica como típicos da música brasileira. De maneira certeira, um dos poucos exemplos citados ajusta-se com precisão à melodia da segunda parte de Medroso de amor:

É até curioso de notar que certas frases européias que nem:

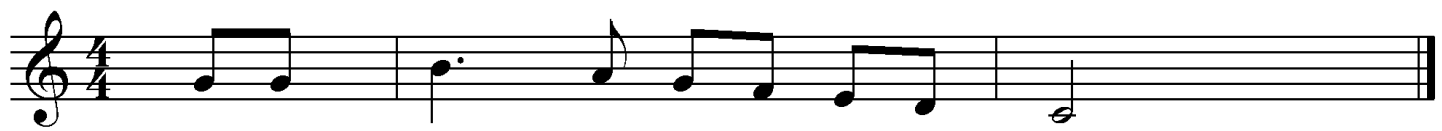

em que a gente percebe um modismo bastante portuga, ficam bem mais brasileiras se a queda terminar na mediante:

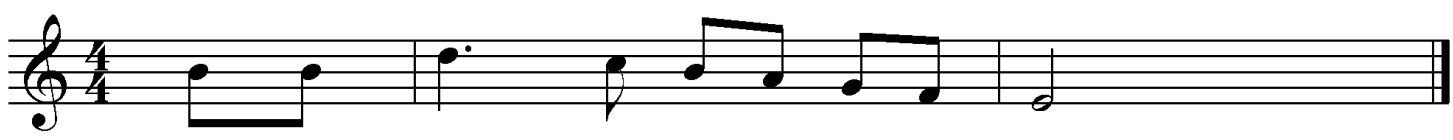

(ANDRADE, 1962, p. 48).

É exatamente o que acontece com a melodia do opus $17 \mathrm{n}^{\circ} 1$ :

EXEMPLO 63: A. NEPOMUCENO. Medroso de amor, c. 10-11

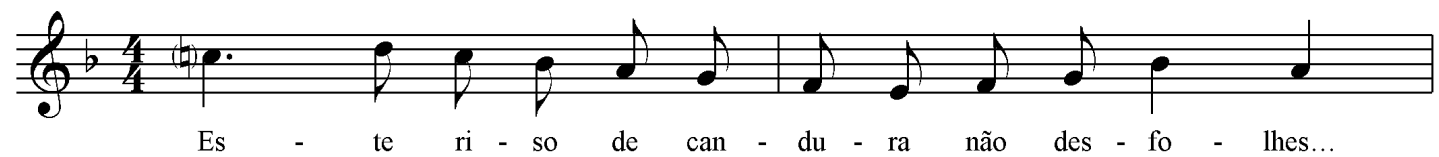

PIGNATARI, Dante (Ed.). Canções para voz e piano. São Paulo: EDUSP, 2004, p. 118. 
Na frase final (idêntica à dos compassos 13-15), o gesto melódico descendente engata em outro ascendente que incorpora requebros flautísticos típicos do choro da época, elaborados a partir das appoggiature estruturais que permeiam toda a canção.

A segunda peça que integra o opus 17, Madrigal, é uma abordagem diferente de absorção e aplicação da rítmica e da melódica brasileira na canção erudita. Após uma introdução feita pelo piano, por certo sincopada à moda brasileira, temos o que seria um recitativo propriamente dito (a indicação para a voz na sua entrada é recitando com vivacidade): a voz entra a capella, e o acompanhamento descarnado faz apenas uma pontuação harmônica, aproximando-se muito mais do recitativo secco característico da ópera buffa que do arioso privilegiado pelo gênero sério. Tal opção é adequada ao caráter irônico das palavras e obedece à indicação de caráter da peça colocada no início da introdução instrumental: Com faceirice. A melodia cantada é pura faceirice brasileira, e parece refletir o universo melódico que animava o teatro musical da época, ou seja, a opereta nacional, terreno que Nepomuceno certamente conhecia e no qual faria uma incursão anos depois, movido por necessidades materiais (PEREIRA, 2007, p. 224).

EXEMPLO 64: A. NEPOMUCENO. Madrigal, c. 5-13
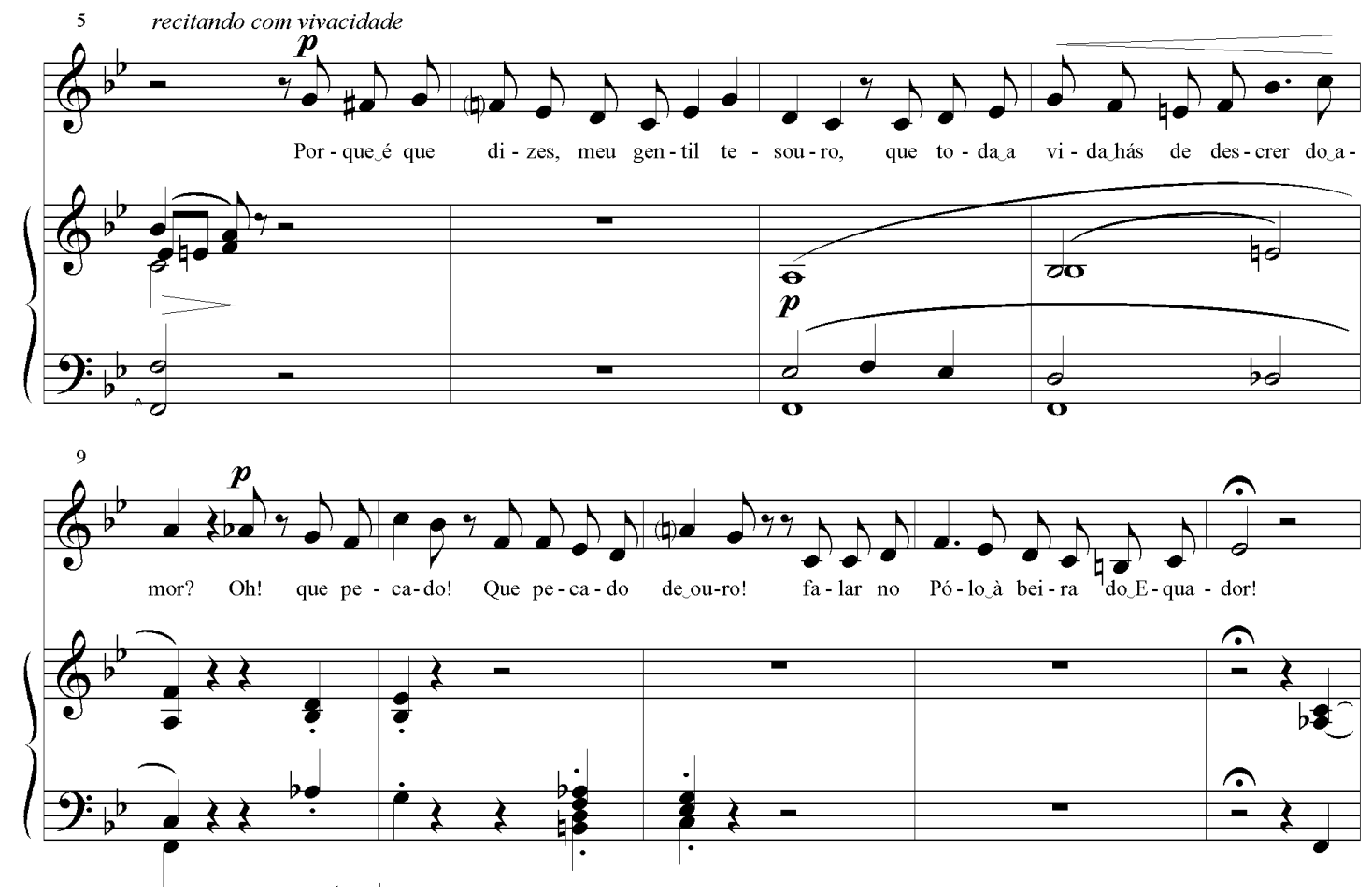

PIGNATARI, Dante (Ed.). Canções para voz e piano. São Paulo: EDUSP, 2004, p. 121. 
À introdução/abertura instrumental e este recitativo segue-se o que seria a canção propriamente dita, uma seção muito mais extensa e que equivale ao cantabile da cena operística tal como foi definida e codificada por Rossini, que vinha depois da scena, constituída pelos recitativos e $\operatorname{ariosos}^{24}$. O andamento é metade do anterior, o acompanhamento é de baixos em oitavas sustentando acordes sincopados, agora à européia: o objetivo é tensionar a linha melódica deslocando os acordes para as partes fracas dos tempos do compasso. São duas frases que levam ao ponto culminante da canção, um recitativo declamado (a indicação de andamento é Largamente) que por sua vez conduz de volta ao lirismo anterior, sendo o acompanhamento agora não mais sincopado, e sim de acordes repetidos:

EXEMPLO 65: A. NEPOMUCENO. Madrigal, c. 33-37

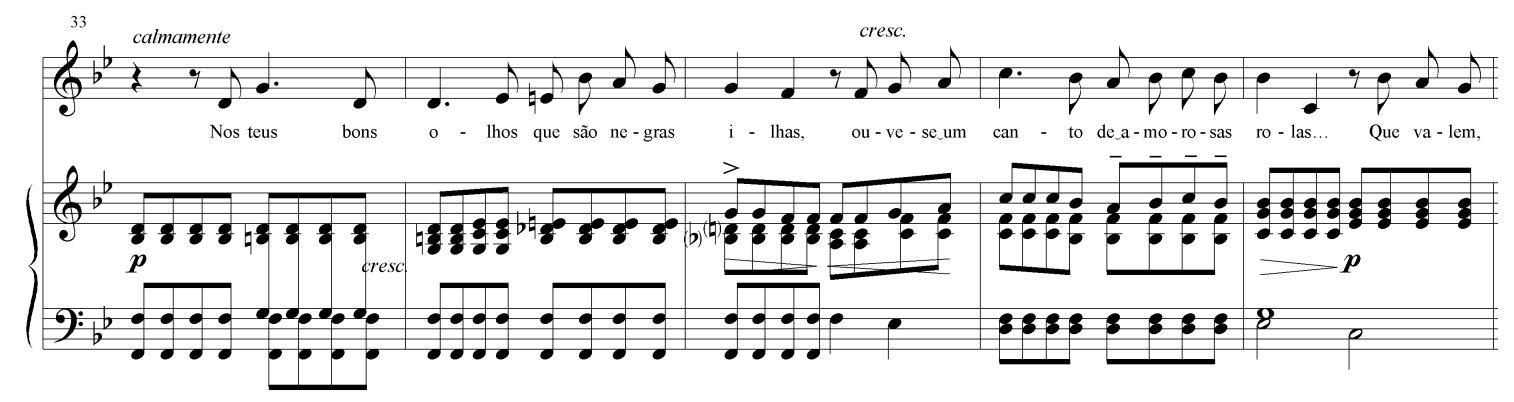

PIGNATARI, Dante (Ed.). Canções para voz e piano. São Paulo: EDUSP, 2004, p. 122-123.

Essa solenidade européia termina com os versos eu hei de ver todo esse gelo agreste / num rubro orvalho desfazer-se em beijos!, desfazendo-se também com o retorno da introdução do início da peça e a repetição do recitativo inicial. A canção se encerra com uma codetta que, com seus requebros flautísticos, não ficaria mal como conclusão de algum chorinho instrumental da época. É o calor brasileiro dissolvendo o gelo europeu:

\footnotetext{
${ }^{24}$ Ver ROSEN, The Romantic Generation, p. 608.
} 


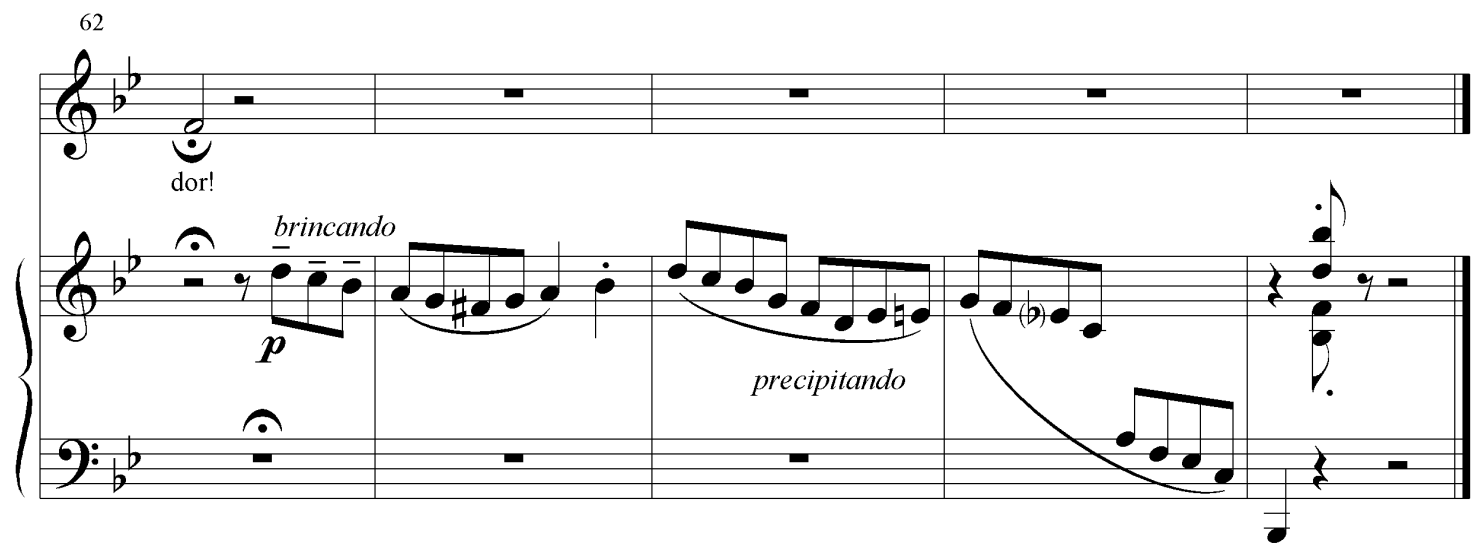

PIGNATARI, Dante (Ed.). Canções para voz e piano. São Paulo: EDUSP, 2004, p. 124.

A forma é bastante complexa, basicamente uma forma-canção (ABA) assimétrica emoldurada por um recitativo precedido de uma introdução instrumental e, no final, seguido por uma conclusão também instrumental. Entretanto, a forma da totalidade da canção também é um ABA, sendo A a parte "brasileira" e B a seção "européia". A mistura de gêneros, especialmente ópera e canção, ocorre também na nacionalidade da música, que é essencialmente mestiça: mais explicitamente brasileira na introdução e na conclusão, mais ambígua na seção central. A parte vocal desta não tem nada de obviamente nacional, mas está demasiadamente contaminada pela música do idioma para que pudesse ser atribuída a algum compositor europeu. Já nesse estágio inicial, Nepomuceno vai criando um estilo próprio a partir de algumas características da música popular e, principalmente, da prosódia e do desenho melódico da língua portuguesa falada no Brasil. 
CAPÍTULO 10 - As CANÇÕES BRASILEIRAS III (1896-1897)

Ao chegar ao Rio de Janeiro em 1895, Nepomuceno instalou-se com a família em Petrópolis. Todas as canções compostas após o retorno ao Brasil até 1904, um total de 25, foram escritas na cidade serrana. Entretanto, apenas três peças têm 1896 e 1897 como ano de composição. A produção regular de canções somente será retomada em 1899. Se de fato o Opus 17 foi criado ainda em Paris em 1895, como alega o Catálogo Geral (CG), isso significa que as três canções de 1896-1897, que permaneceram em manuscrito, foi toda a música que Nepomuceno conseguiu escrever entre seu retorno da Europa em 1895 e 1899, quando temos as seis canções dos Opus 18, 19 e 20. Viviana Mónica Vermes, em sua dissertação sobre a música para piano de Nepomuceno, enumera possíveis razões para produção tão escassa:

[...] parece-nos sintomática a existência de uma carta de Alexandre Guilmant,
datada de 18 de outubro desse ano (1895), na qual ele atesta der dado aulas a
Nepomuceno e elogia o aproveitamento de seu aluno. Acreditamos que
Nepomuceno, rigoroso em sua correção, tenha-se apressado em solicitar o atestado
ao mestre para poder documentar seus estudos e justificar assim a sua indicação à
cadeira de órgão do INM, talvez como resposta à crítica de Guanabarino. Esta
passagem, como outras que se verificarão durante a vida do compositor, deixam-nos
perceber quanto tempo precioso de sua vida produtiva como artista ele despendeu
respondendo a ataques e tentando provar a sua inocência em acusações que lhe eram
dirigidas. [...] Este cuidado de Nepomuceno em esclarecer e evidenciar sua
idoneidade aponta não apenas para o seu cuidado com a própria imagem, como
também, talvez até mais, para quanto essas acusações o preocupavam e magoavam,
quanto era vítima dessa sensação de injustiça que afetaria não apenas a sua
produção (de maneira indireta, pelo tempo desviado para esclarecimentos) como a
sua saúde frágil. Essa 'perda de tempo' é um dado que consideramos importante no
curso da vida de Nepomuceno. A sua dedicação a atividades diversas (aulas no
INM, particulares no Sacré Coeur, regência, administração do INM) e a necessidade
dos deslocamentos de Petrópolis ao Rio de Janeiro durante parte de sua vida, além
da peculiaridade apontada acima, ajudam-nos a delinear um ritmo de vida em que a
atividade de Nepomuceno se ressentia da dispersão. (VERMES, 1996, p. 36-37).

Sempre de acordo com o Catálogo Geral (CG), a única peça produzida em 1896 é Morta (Trovas do Norte). A peça não foi publicada, e a única cópia a que tivemos acesso é um manuscrito não autógrafo com muitos erros. A ausência de indicações de dinâmica, ligaduras etc. leva a crer que Nepomuceno tenha abandonado a peça nesse estágio de acabamento tosco, o que de resto se aplica também a outra canção desse período, Cantos da Sulamita, de 1897. O texto de Antonio Salles descreve uma cena noturna, em que uma jovem agonizante, cercada pelos seus, finalmente expira. A parte vocal é uma recitação sobre uma mesma nota repetida como se fosse uma ladainha: imagina-se as pessoas rezando ao redor do leito da menina moribunda. Já o acompanhamento de piano começa com acordes apoiados 
sobre notas-pedal no baixo que, apesar do compasso ternário, imprimem à música o caráter de uma marcha fúnebre (a indicação de andamento é Muito devagar):

EXEMPLO 67: A. NEPOMUCENO. Morta, c. 5-9

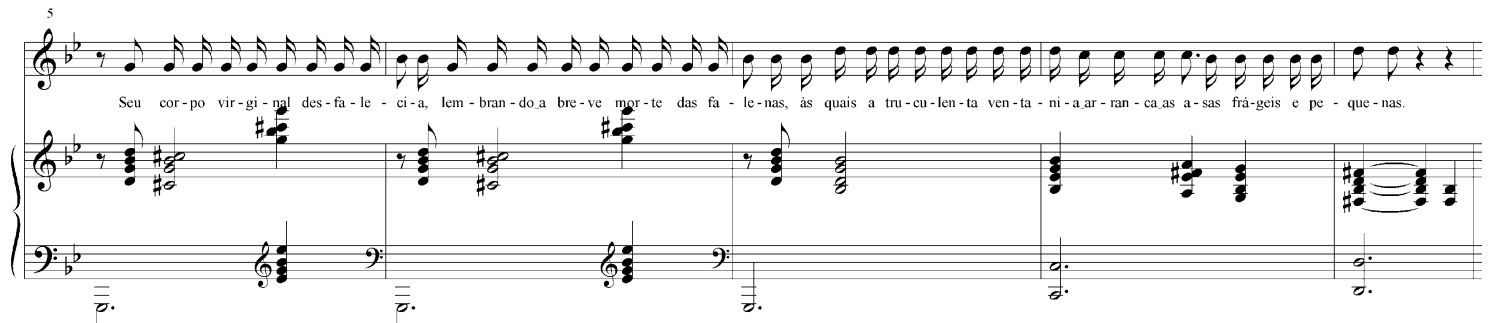

PIGNATARI, Dante (Ed.). Canções para voz e piano. São Paulo: EDUSP, 2004, p. 127.

No momento em que o texto passa a descrever a brisa (um suave ruflar de etéreas penas), a mão direita do piano ganha movimento em um desenho de figurações delicadas:

EXEMPLO 68: A. NePOMUCENO. Morta, c. 12-15

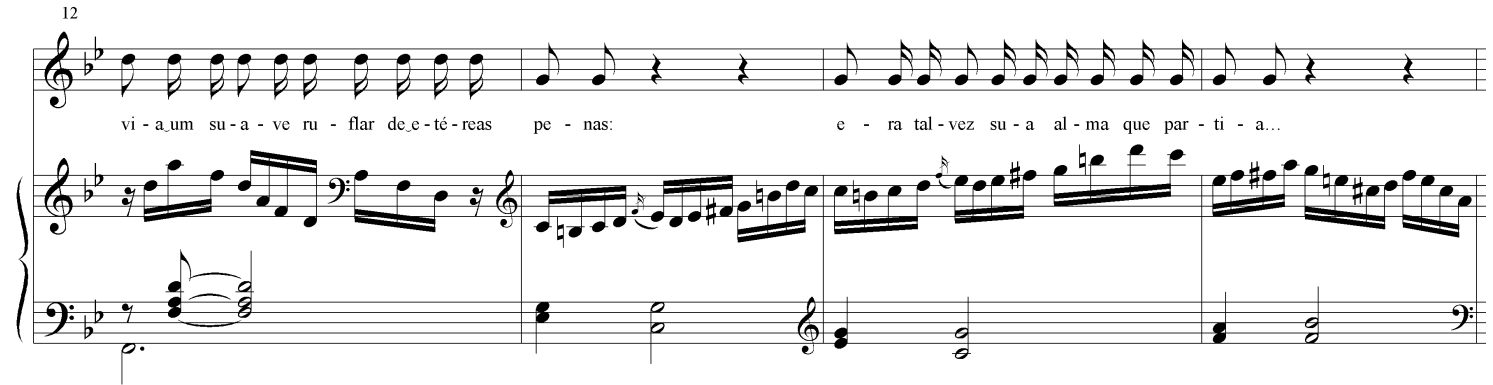

PIGNATARI, Dante (Ed.). Canções para voz e piano. São Paulo: EDUSP, 2004, p. 127-128.

No final, a música modula para a relativa maior (a tonalidade original é sol menor), e os acordes que encerram a canção ilustram a nova estrela que passa a brilhar no céu quando a ele sobe a alma da falecida:

EXEMPLO 69: A. NEPOMUCENO. Morta, c. 24-28

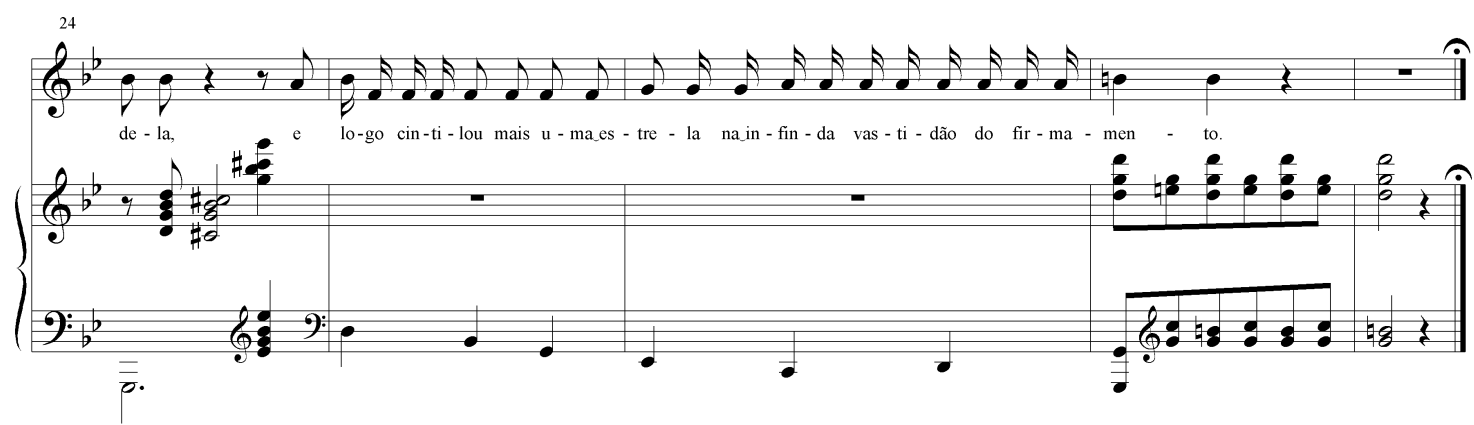

PIGNATARI, Dante (Ed.). Canções para voz e piano. São Paulo: EDUSP, 2004, p. 128. 
Cantos da Sulamita, sobre poema de Múcio Teixeira, é outra canção bastante problemática, ao menos pelo que se pode inferir da cópia a que tivemos acesso, na mesma caligrafia da canção anterior, com muitos erros e em um estágio bastante tosco de acabamento. Assim como deve ter acontecido com Morta, ao chegar nessa etapa da criação da canção, Nepomuceno deve ter-se dado conta de sua inviabilidade e a abandonou. Nas duas canções, o que mais chama a atenção é a rítmica, aparentemente a preocupação básica do compositor ao conceber as ambientações. Em Morta é a recitação silábica em que os valores (semicolcheias, colcheias ou tercinas de colcheias e semicolcheias) dão conta das sílabas que compõem os versos, adequando a agógica destes à acentuação dos compassos:

EXEMPLO 70: A. NEPOMUCENO. Morta, c. 17-18

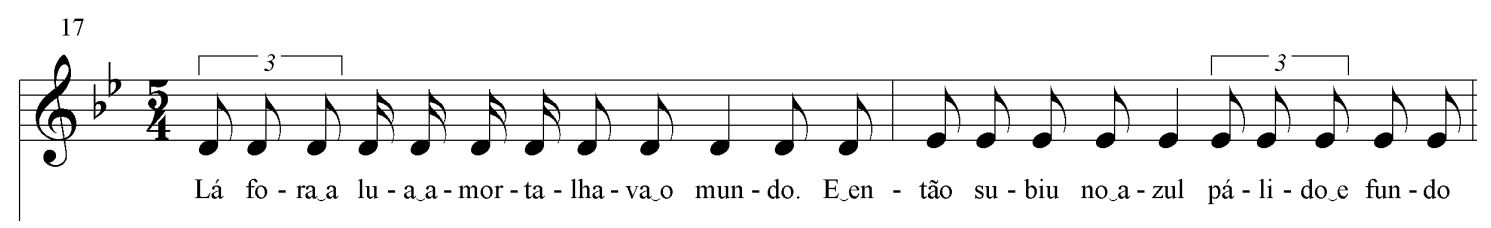

PIGNATARI, Dante (Ed.). Canções para voz e piano. São Paulo: EDUSP, 2004, p. 128.

Em Cantos da Sulamita, é a subdivisão binária e ternária dos tempos do compasso e o jogo de três contra dois entre a parte vocal e o acompanhamento:

EXEMPLO 71: A. NEPOMUCENO. Cantos da Sulamita, c. 5-8

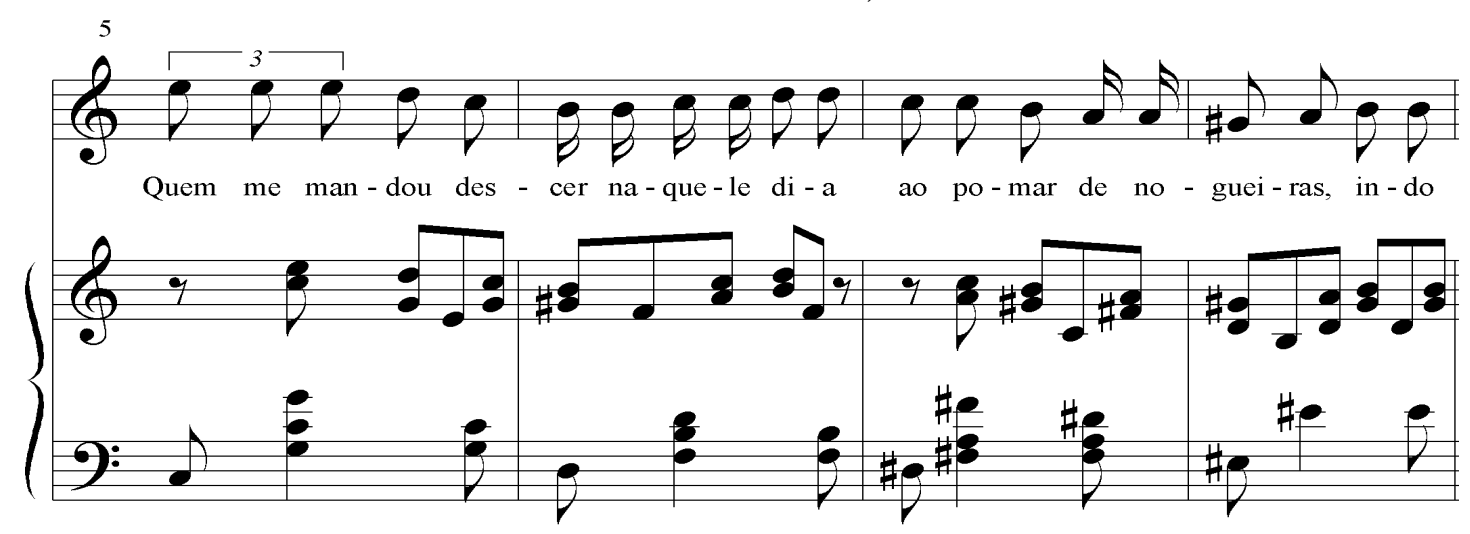

PIGNATARI, Dante (Ed.). Canções para voz e piano. São Paulo: EDUSP, 2004, p. 125.

A terceira canção produzida nesse período é Epitalâmio, novamente um poema de Antonio Salles. É evidente que a canção foi concebida para orquestra, sendo a versão para piano uma redução feita por outra pessoa que não o autor. Somente encontramos o manuscrito autógrafo da versão orquestral. Epitalâmio é a única canção de Nepomuceno concebida originalmente para orquestra; todas as outras versões são transcrições feitas por outros autores. 
Em 1899 Nepomuceno retoma a publicação de canções que tinha sido interrompida após o Opus 17. As duas canções Opus 18, Coração triste, com texto de Machado de Assis, e Filomela, poema de Raymundo Corrêa, evitam de maneira quase ostensiva qualquer referência explicitamente nacional. O compositor parece aqui revisitar o lied alemão, o que as canções do opus seguinte confirmam: o Opus 19 consiste de dois lieder, um poema de Heine e outro da Condessa Amadei. Em ambas, o original alemão tem uma versão em português, providenciada quase certamente pelo próprio compositor juntamente com as variantes rítmicas necessárias para adequar a parte vocal aos diferentes idiomas:

EXEMPLO 72: A. NEPOMUCENO. Sonhei, c. 11-18

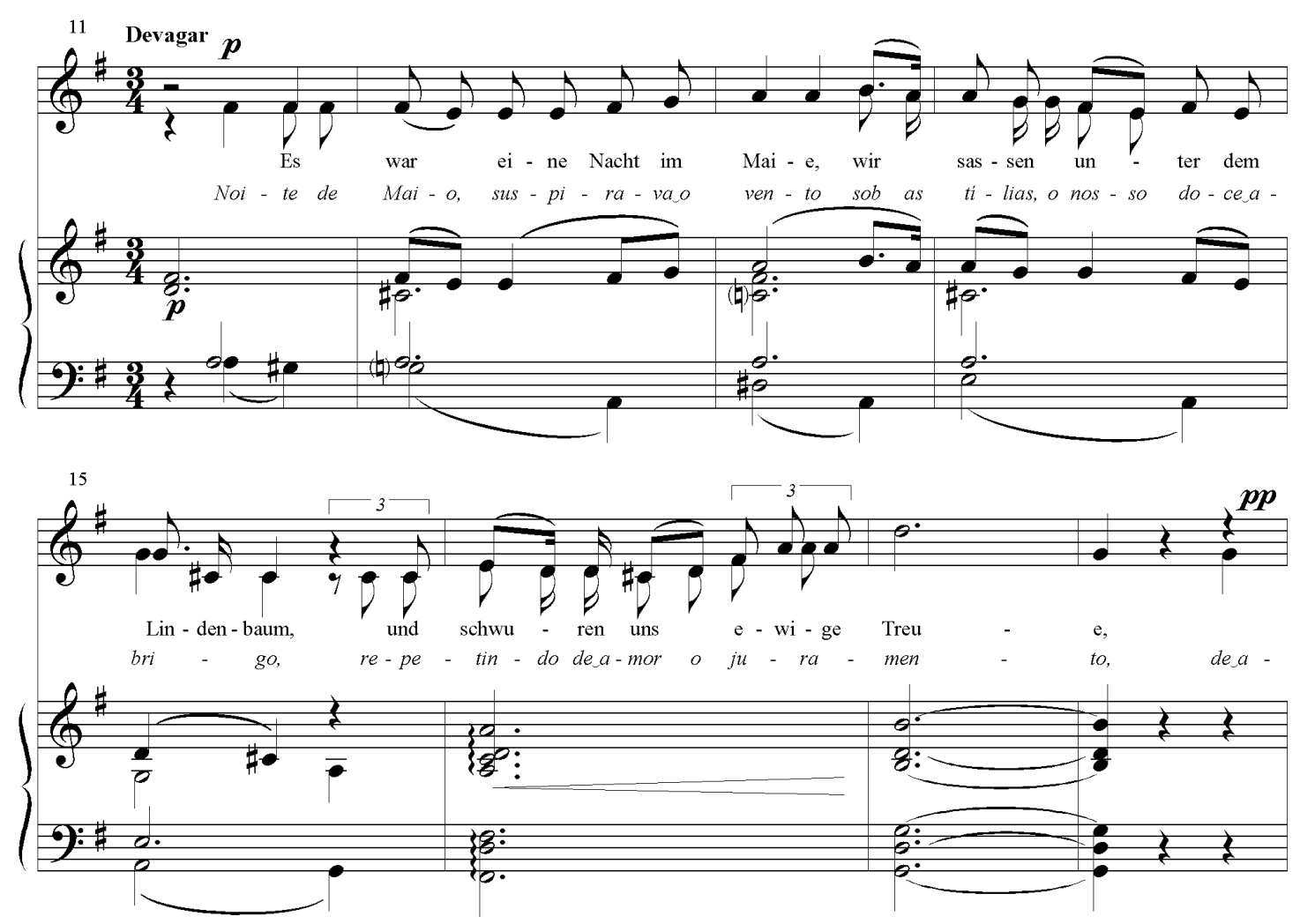

PIGNATARI, Dante (Ed.). Canções para voz e piano. São Paulo: EDUSP, 2004, p. 147. 


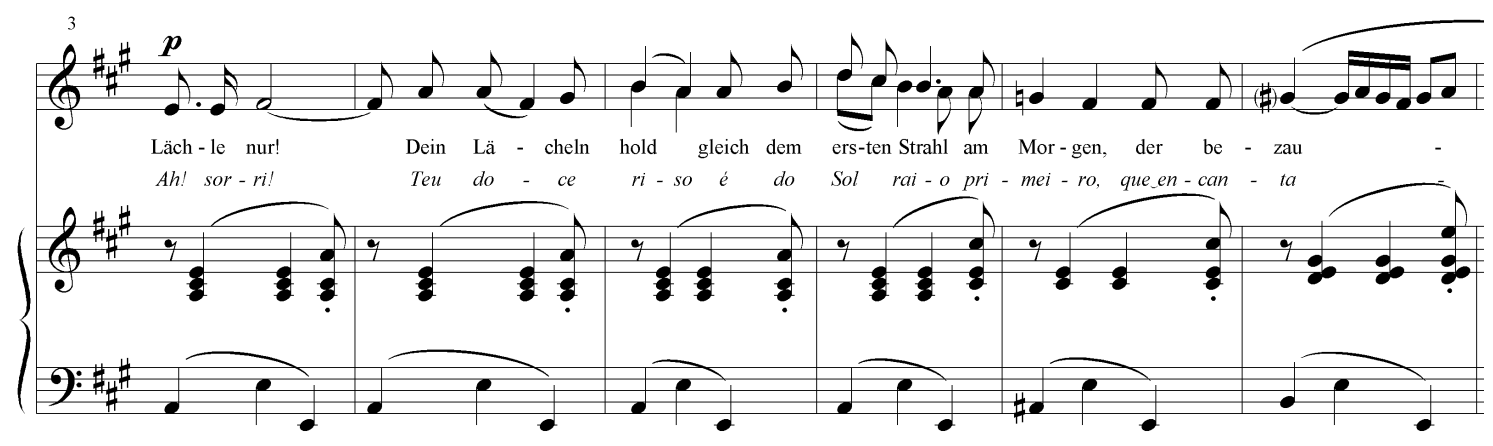

PIGNATARI, Dante (Ed.). Canções para voz e piano. São Paulo: EDUSP, 2004, p. 150.

Embora seja impossível afirmar com segurança, a análise dessas variantes leva a crer que a música prioriza o texto traduzido, ou que pelo menos foi composta adaptando simultaneamente as duas versões. Os recursos harmônicos e formais utilizados nas ambientações tanto do Opus 18 como do 19 têm sua origem no lied. O mesmo pode ser dito do caráter de cada uma das peças: tanto a tristeza outonal de Coração triste como a longa cena dramática de Filomela, a veia cômica de Sonhei e o lirismo de Canção de amor têm protótipos europeus. Ainda assim, nenhuma dessas canções é convincente como criação européia. As melodias cantadas, forçosamente flexionadas pelo idioma, faz com que soem híbridas, talvez inteiramente "brancas" quanto à raça, mas ainda assim mestiças. É como se, nessas canções, Nepomuceno se fosse apropriando dos diversos elementos e recursos que se encontram no cerne do lied, e a maneira de fazê-lo fosse contaminá-lo com a língua nacional. Esse estilo híbrido, ora mais carregado de brasilidade, ora inclinando-se mais acentuadamente para a Europa, como no caso destas canções, é essencialmente o estilo pessoal do compositor e, talvez, sua mais importante contribuição para a constituição de uma música brasileira.

As duas canções Opus 20, as últimas criadas ainda no século XIX, se destacam na obra de Nepomuceno. Em Xácara o compositor retoma a idéia rítmica básica de Cantos da Sulamita, levando-a para o universo popular. A fórmula rítmica do acompanhamento de Cantos da Sulamita é uma variação do ritmo de habanera em que a nota pontuada seguida de semicolcheia deste:

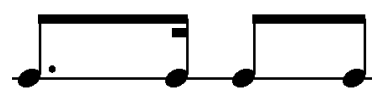

é substituída por uma tercina:

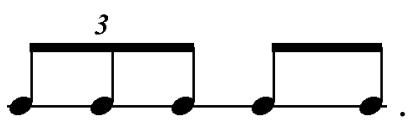


Essa alternância entre a subdivisão ternária e binária dos tempos do compasso se repete na melodia, mas invertida. $\mathrm{O}$ resultado é uma constante polirritmia de 3 x 2 entre o acompanhamento e a voz que tensiona a música como um todo e lhe confere, simultaneamente, a ginga característica dos ritmos de origem africana que estão na base de boa parte da música popular brasileira:

EXEMPLO 74: A. NePOMUCENO. Xácara, c. 1-8
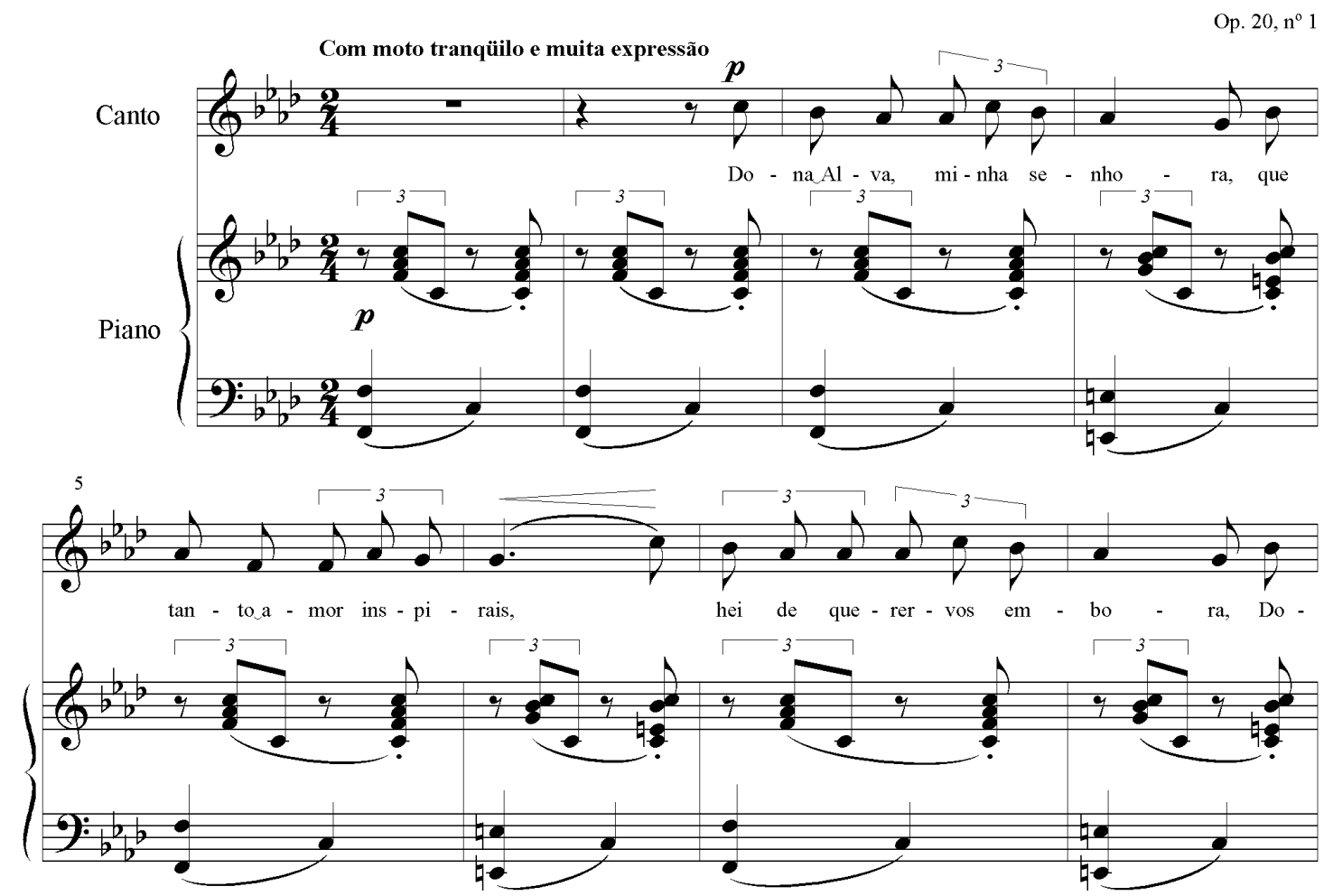

PIGNATARI, Dante (Ed.). Canções para voz e piano. São Paulo: EDUSP, 2004, p. 153.

Abaixo, um exemplo da música popular coletado por Mário de Andrade:

\section{EXEMPLO 75: NITINHO PINTOR. Toada de violeiro}

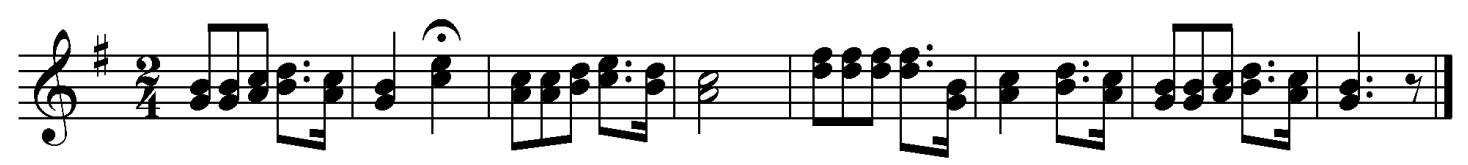

(ANDRADE, 1962, p. 132)

Essa fórmula rítmica repetitiva e aparentemente limitadora adapta-se com naturalidade admirável ao texto de Orlando Teixeira, e parece derivar dele. Na verdade, é exatamente isso o que acontece: lido ritmicamente, o texto parece pedir a rítmica a ele aplicada por Nepomuceno. Essa utilização de subdivisões binárias, ternárias, em quatro e até em seis partes 
(c. 26) do tempo, sempre dependendo do número de sílabas de que as notas devem se encarregar, implica também uma certa imprecisão rítmica na parte da voz, imprecisão esta limitada pelo acompanhamento, que deve ser executado em tempo estrito. O resultado é uma espécie de rubato $^{25}$ tipicamente brasileiro. Por outro lado, ao dirigir-se à amada na segunda pessoa do plural, o poeta faz com que cada segundo verso termine em "ais": Nepomuceno destaca essa sílaba já quando surge pela primeira vez, no compasso 6, prolongando-a em uma semínima pontuada que termina com um portamento quarta acima, um suspiro quase gemente que nos remete imediatamente ao fado português e à modinha, com seus 'ais' sentimentais.

Fundamentalmente, é essa elasticidade rítmica derivada do texto que, em primeira instância, confere às melodias de Nepomuceno seu caráter brasileiro mesmo quando não há elementos nacionais mais explícitos. Ainda assim, os contornos melódicos que revestem os textos nacionais também assumem desenhos que de alguma maneira ampliam os gestos da língua falada. Nas canções de Nepomuceno, a linguagem musical européia cede às exigências rítmico-melódicas específicas dos textos que reveste, e assim se nacionaliza. Um exemplo importante é a canção Op. 20 n $^{\circ}$ 2, Oração ao diabo, que foi orquestrada e apresentada por Villa-Lobos por ocasião das homenagens prestadas a Nepomuceno após sua morte em $1920^{26}$. Nepomuceno reproduz neste Opus 20 o mesmo esquema de pareamento do Opus 17, estando a primeira canção do par próxima do universo popular, e a segunda revisitando o mundo da ópera, aqui a opera seria. A introdução do piano, uma escala em tons inteiros, fortissimo, em oitavas em movimento contrário, leva à tônica da peça, ré menor (ver exemplo abaixo).

A escala de tons inteiros, um recurso típico da música de Debussy, aparece pela primeira vez no cancioneiro; não será a última. Essa aproximação da vanguarda francesa é um passo importante na atualização da música brasileira empreendida por Nepomuceno: além de criar uma música brasileira, o compositor pretendia também que esta se alinhasse com o que havia de mais moderno na Europa, e Oração ao diabo é um marco nessa empreitada.

A primeira parte da canção é uma invocação ao diabo, um recitativo operístico solene, carregado de drama, quase histriônico (a indicação do caráter da voz é Com desespero), com

\footnotetext{
${ }^{25}$ Rubato (ou tempo rubato): Importante recurso de expressividade na execução, envolvendo flexibilidade na escolha do tempo dentro de um compasso ou frase. Isso é normalmente realizado mediante trocas em bases iguais, quando uma nota tocada ligeiramente mais tarde em relação à marcação estrita é compensada por outra tocada ligeiramente mais cedo, de modo que a frase, tomada como um todo, não deixa de respeitar o seu tempo. [Italiano: (tempo) roubado] (ISAACS, 1985, p. 327).

${ }^{26}$ Ver CORRÊA, 1996, p. 55.
} 
saltos de sétima e de oitava na voz, acompanhados no piano por acordes e, a partir do compasso 10, tremolandi sobre um baixo em oitavas:

EXEMPLO 76: A. NEPOMUCENO. Oração ao diabo, c. 1-16

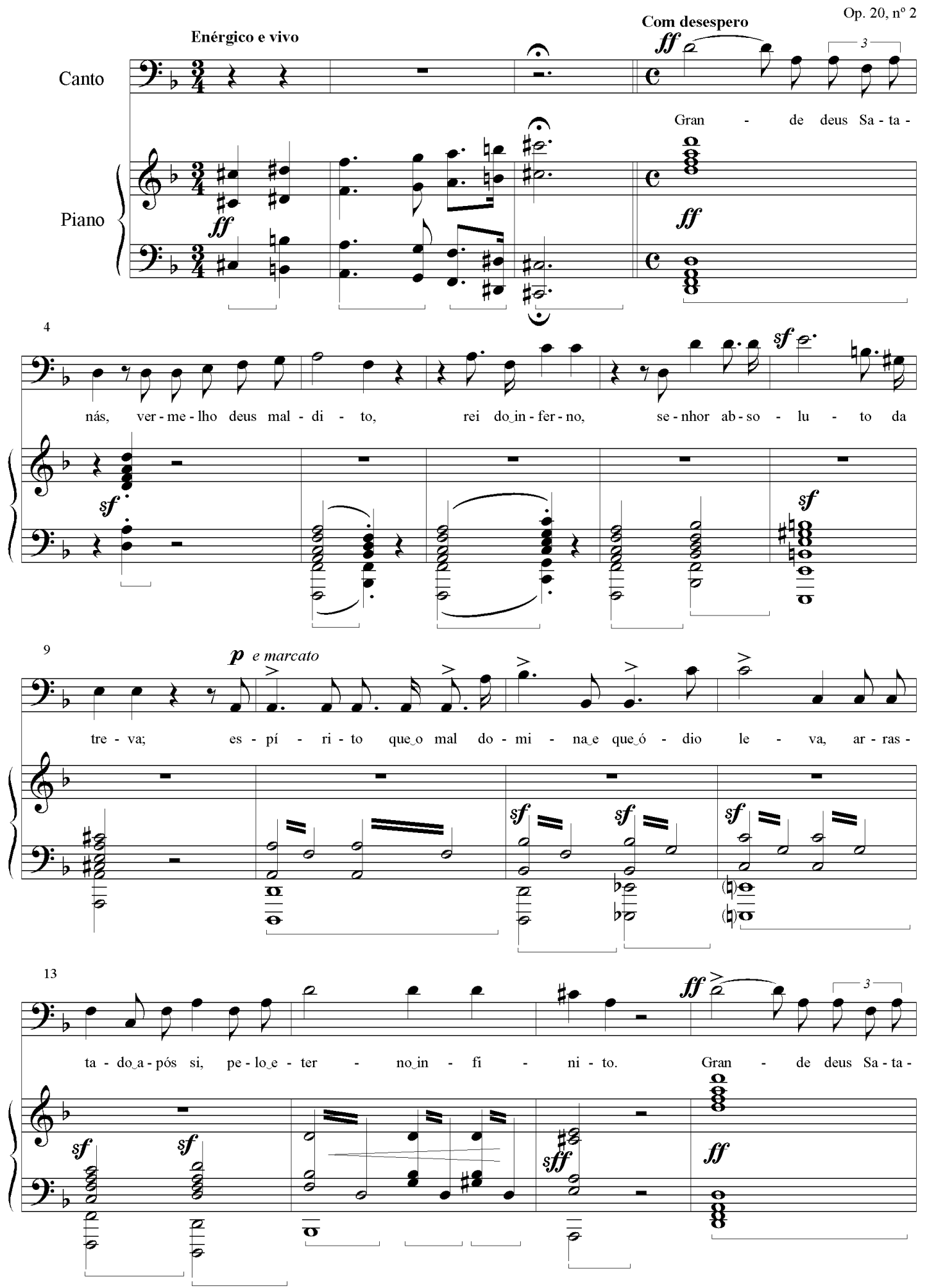

PIGNATARI, Dante (Ed.). Canções para voz e piano. São Paulo: EDUSP, 2004, p. 157. 
Segue-se a canção propriamente dita, uma prece cheia de fervor e lirismo (a indicação de andamento e caráter é Menos e com muito sentimento) em que o poeta primeiro descreve a própria alma. Trata-se na verdade de um dueto entre a voz e a melodia do piano, acompanhado por arpejos pedalizados na mão esquerda, o que confere ao trecho uma certa qualidade de Noturno:

EXEMPLO 77: A. NEPOMUCENO. Oração ao diabo, c. 17-22
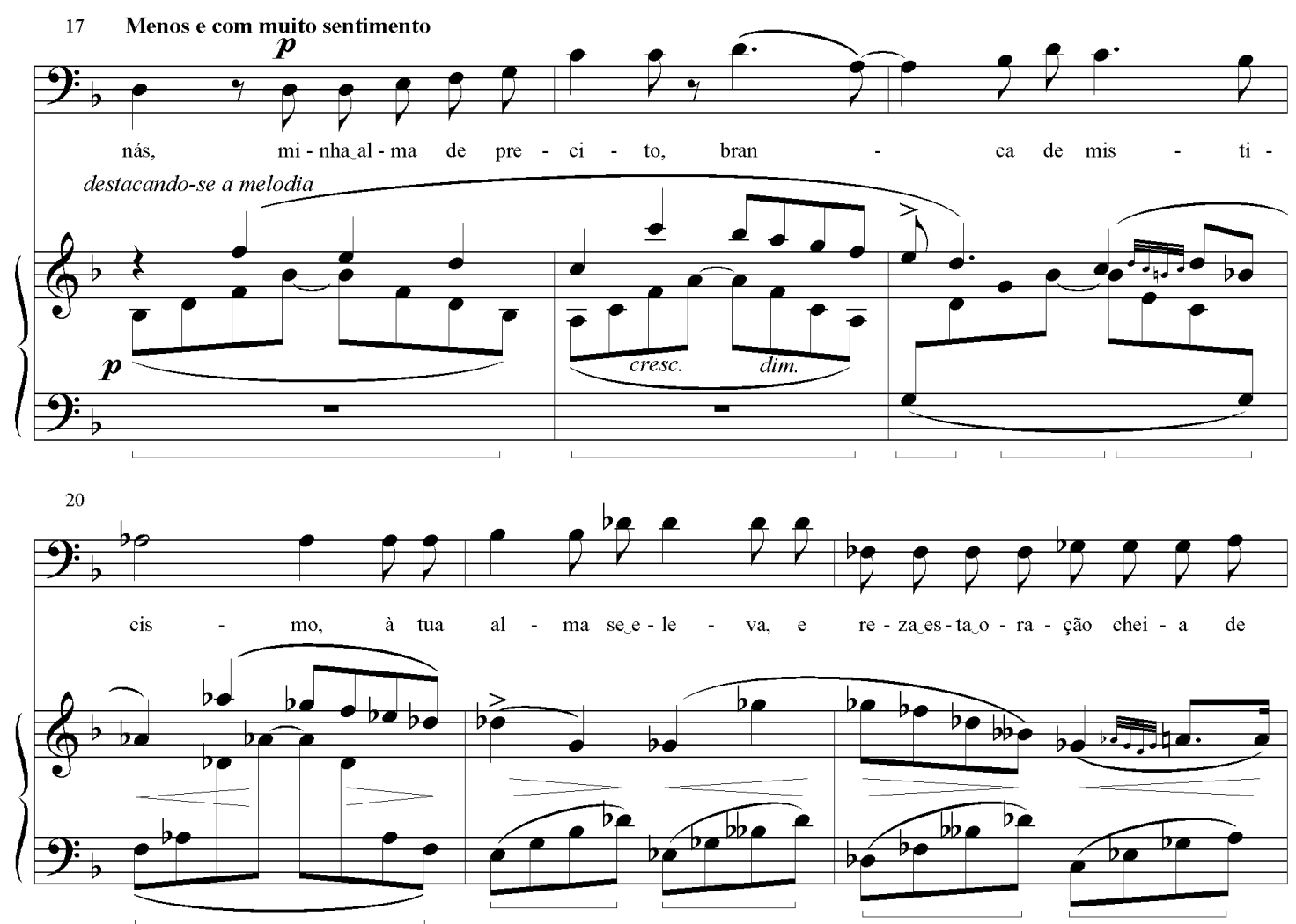

PIGNATARI, Dante (Ed.). Canções para voz e piano. São Paulo: EDUSP, 2004, p. 158.

O dueto é interrompido por dois compassos e meio de recitativo que dão um ar de mistério ao verso "coeva da antiga crença azul do boi Ápis no Egito": 
EXEMPLO 78: A. NEPOMUCENO. Oração ao diabo, c. 23-25

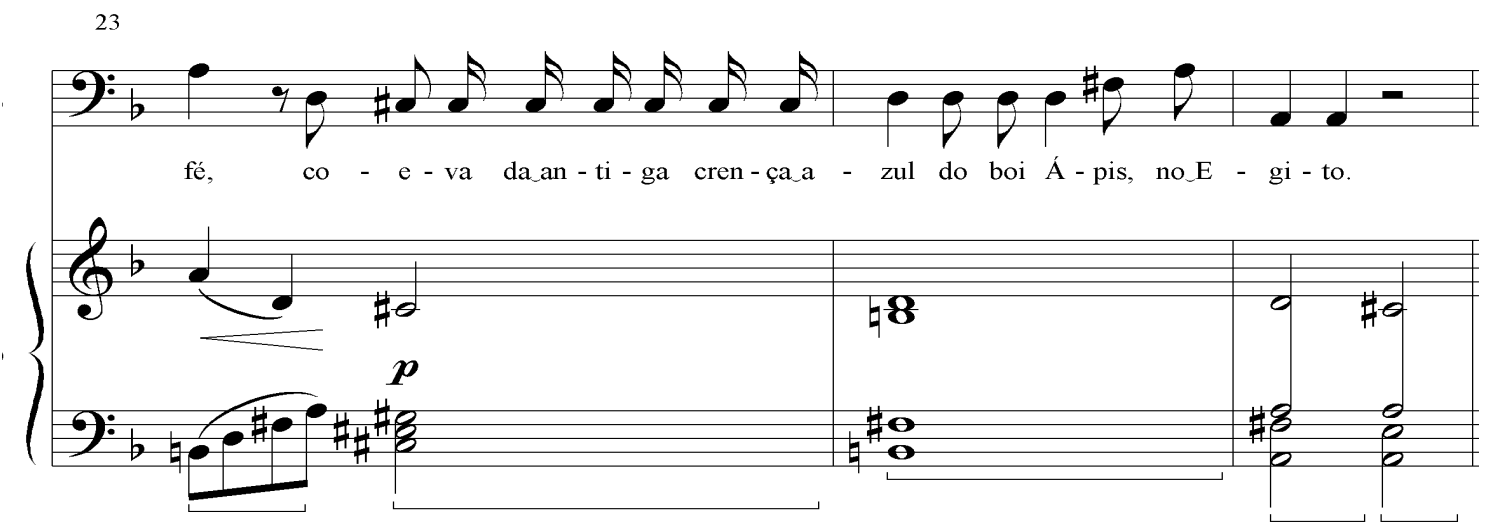

PIGNATARI, Dante (Ed.). Canções para voz e piano. São Paulo: EDUSP, 2004, p. 158.

Segue-se novamente o noturno lírico, sem melodia instrumental, prosseguindo a voz agora solista com uma variação da melodia que no dueto estava a cargo do piano para oferecer a alma ao demônio em troca de ser amado pela dos risos bons, a dos olhos de noite:

EXEMPLO 79: A. NEPOMUCENO. Oração ao diabo, c. 33-36

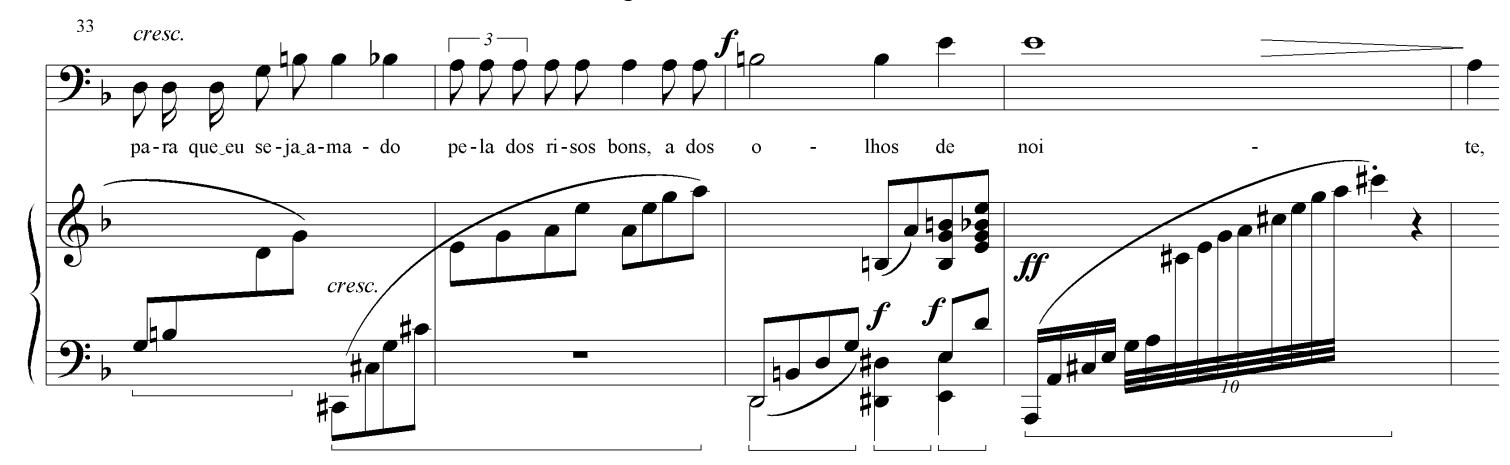

PIGNATARI, Dante (Ed.). Canções para voz e piano. São Paulo: EDUSP, 2004, p. 159.

Retorna a invocação em fortissimo do início da peça, onde o poeta consuma a transação. A cortina se fecha com uma reiteração da introdução por tons inteiros e em oitavas em movimento contrário, accelerando, com a indicação de estrepitoso, culminando em acordes de encerramento na tônica maior: 
EXEMPLO 80: A. NEPOMUCENO. Oração ao diabo, c. 38-43

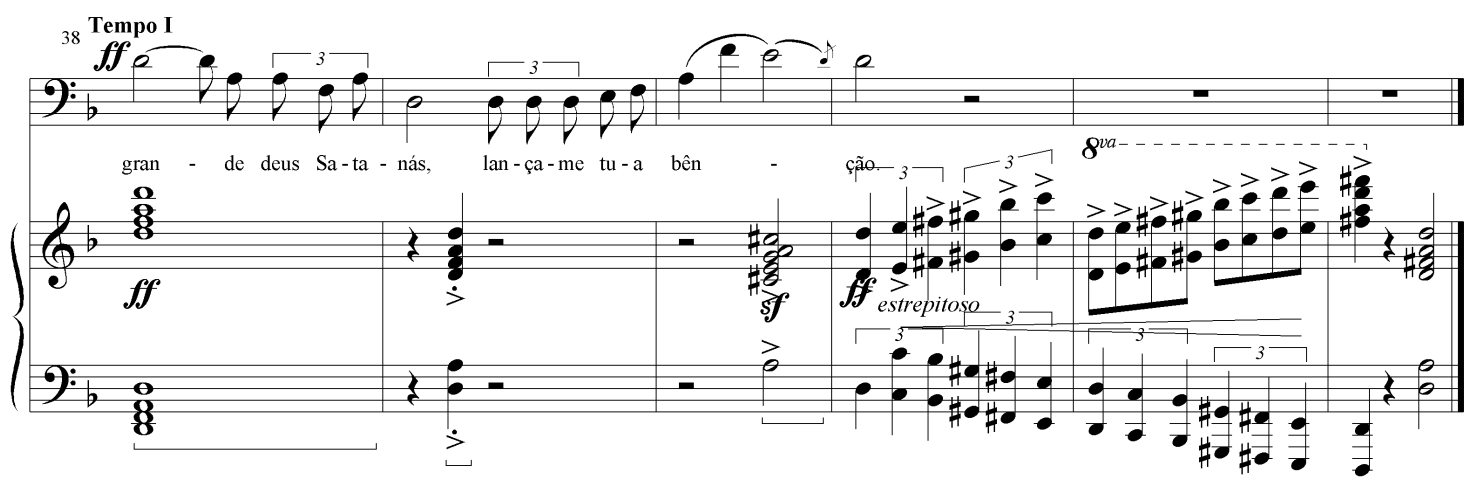

PIGNATARI, Dante (Ed.). Canções para voz e piano. São Paulo: EDUSP, 2004, p. 159.

O que talvez mais chama a atenção em Oração ao diabo é a naturalidade da prosódia, a maneira como o compositor se vale de mecanismos rítmicos simples, que fazem a música oscilar entre o arioso, o recitativo secco e o cantabile belcantista, para expressar o texto com fluidez quase falada:

EXEMPLO 81: A. NEPOMUCENO. Oração ao diabo, c. 26-37

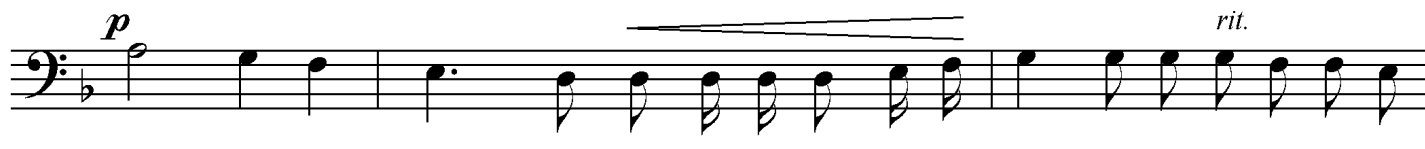

Di - zem que selaIal - ma tens de qual-quer des-gra - ça - do, em tro - ca tu lhe

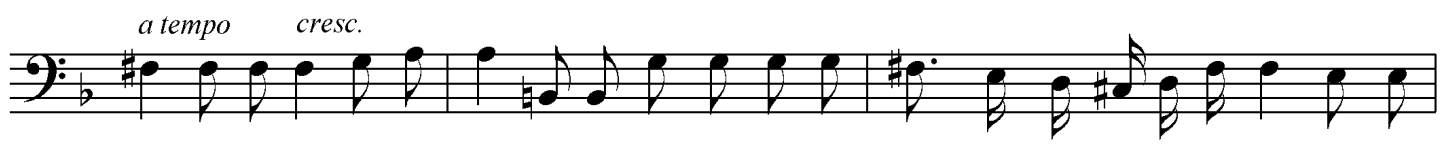

dás das for-tu - nas ola - çoi - te, e delou-tros não sei eu quela teu e - lei-to ven-çam; se

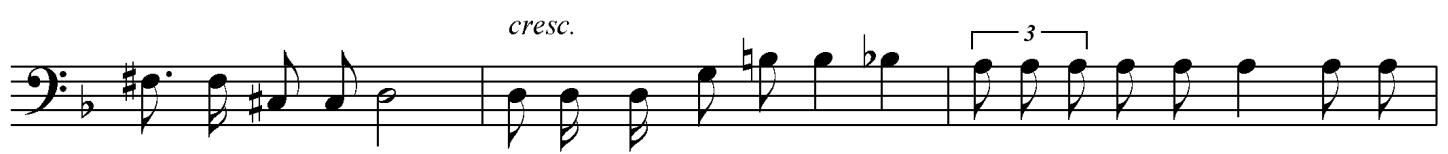

tan - to for mis-ter pa-ra queIeu se-jaIa-ma - do pe-la dos ri - sos bons, a dos

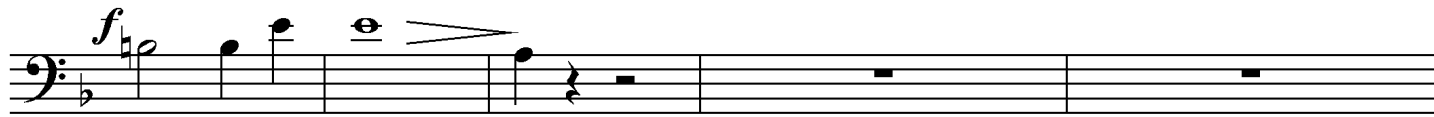

o - lhos de noi - te,

PIGNATARI, Dante (Ed.). Canções para voz e piano. São Paulo: EDUSP, 2004, p. 158-159.

Também se destaca a riqueza de efeitos expressivos obtida com recursos formais extremamente econômicos e engenhosos. Pouco antes do alvorecer do século XX, Nepomuceno publica a que é talvez a primeira obra musical moderna no Brasil. 


\section{CAPÍTULO 12 - As CANÇÕES BRASILEIRAS V (1901)}

1898 fora o ano da ópera Ártemis, que estreou no Teatro Lírico em 14 de outubro e, aparentemente, não foi bem recebida pelo público. Uma "crítica publicada em $O$ País a 16 de outubro fala do desconforto provocado pela harmonia wagneriana sobre o 'poemeto' de Coelho Neto.” (VERMES, 1996, p. 43) Evidentemente concentrado na produção de sua ópera, Nepomuceno não produziu nenhuma canção nesse ano. Sintomaticamente, no ano seguinte temos as seis canções dos opus 18, 19 e 20.1900 é novamente um ano sem canções. No final desse ano ele se dirige outra vez à Europa, agora acompanhado pela família. Desgostoso com a vida musical do Rio de Janeiro, Nepomuceno procura emprego no exterior e tenta apresentar suas obras. A viagem será um retumbante fracasso, pessoal e profissional. O compositor se separa da mulher, que volta para a Noruega com os filhos, os esforços para executar Ártemis em Viena naufragam "nos rochedos da vontade do diretor Mahler" e seu estado de saúde se deteriora (VERMES, 1996, p. 44-47). Por outro lado, é sondado para suceder a Leopoldo Miguez, que ficara gravemente doente, na direção do INM. O fracasso na Europa faz com que novamente volte o olhar para o Brasil, para onde embarca em 25 de setembro de 1901, ano que verá surgir sete canções da pluma de Nepomuceno.

Nas três canções que integram o opus 21 nota-se, por um lado, uma busca por simplicidade: as peças são essencialmente melodias acompanhadas. Por outro, embora nenhuma tenha ritmo explicitamente nacional, percebe-se nas três um balanço que é característico da música brasileira. Na primeira canção, $O$ Sono, sobre poema de Gonçalves Dias, o embalo não é o do berço dos acalantos, mas o da rede, talvez. Esse balanço mais alegre vem fundamentalmente do compasso ternário com subdivisão ternária, 9/8, em vez do 6/8 usualmente utilizado nas canções de ninar:

EXEMPLO 82: A. NEPOMUCENO. O Sono, c. 1-2

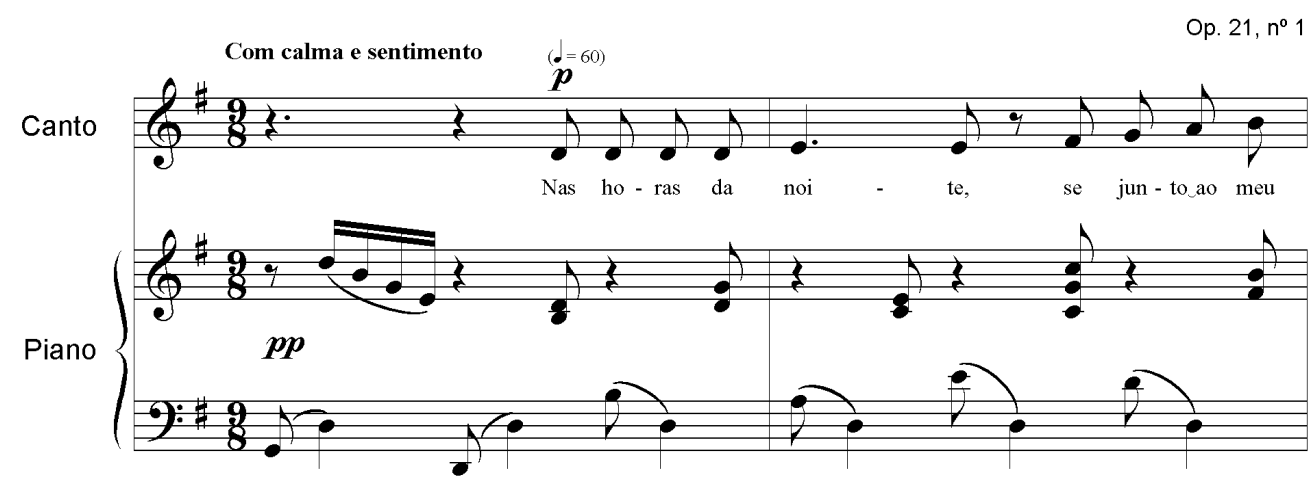

PIGNATARI, Dante (Ed.). Canções para voz e piano. São Paulo: EDUSP, 2004, p. 160. 
Já na segunda, Dolor supremus, de Osório Duque Estrada, são os acordes em síncopa na parte da mão direita do piano que conferem o impulso musical; unidos em appoggiature de dois em dois, conferem um embalo melancólico à melodia:

EXEMPLO 83: A. NePOMUCENO. Dolor supremus, c. 1-5

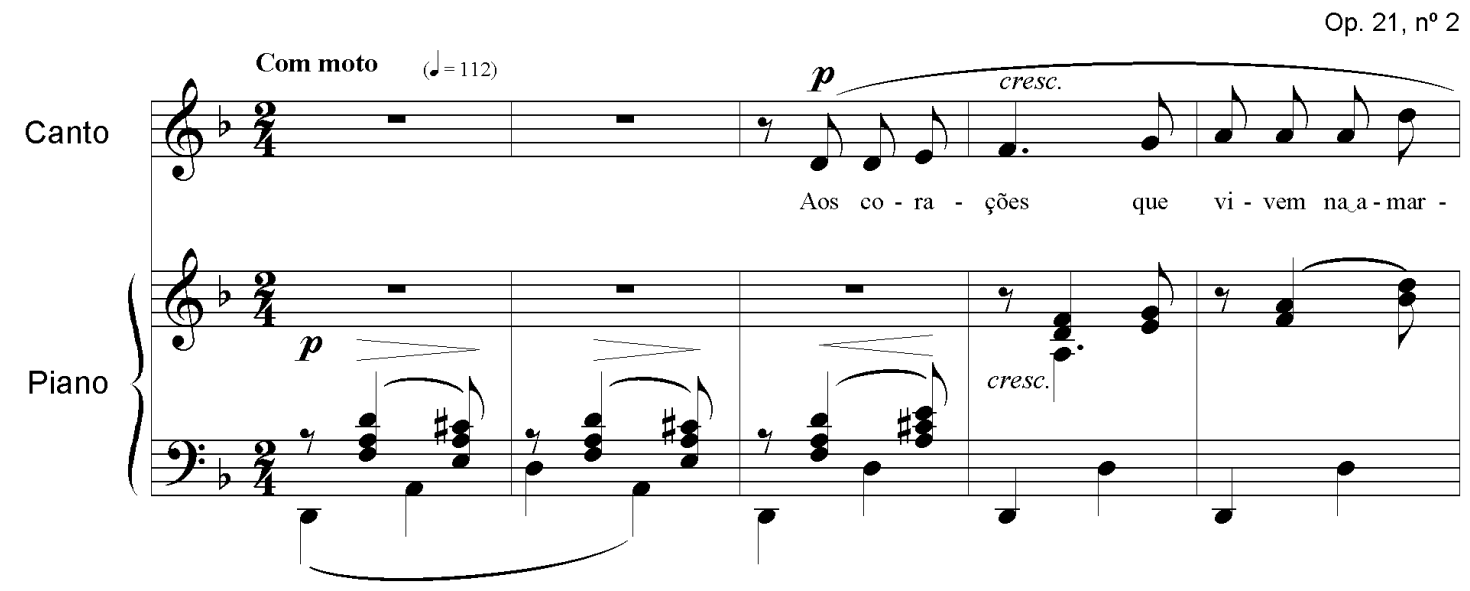

PIGNATARI, Dante (Ed.). Canções para voz e piano. São Paulo: EDUSP, 2004, p. 163.

Os contornos da linha melódica, a tonalidade de ré menor e o balanço lento nos leva a associar esta canção a Coração triste, Op. $18 \mathrm{n}^{\mathrm{o}}$ 1, com a qual compartilha o caráter melancólico:

EXEMPLO 84: A. NEPOMUCENO. Coração triste, c. 3-6

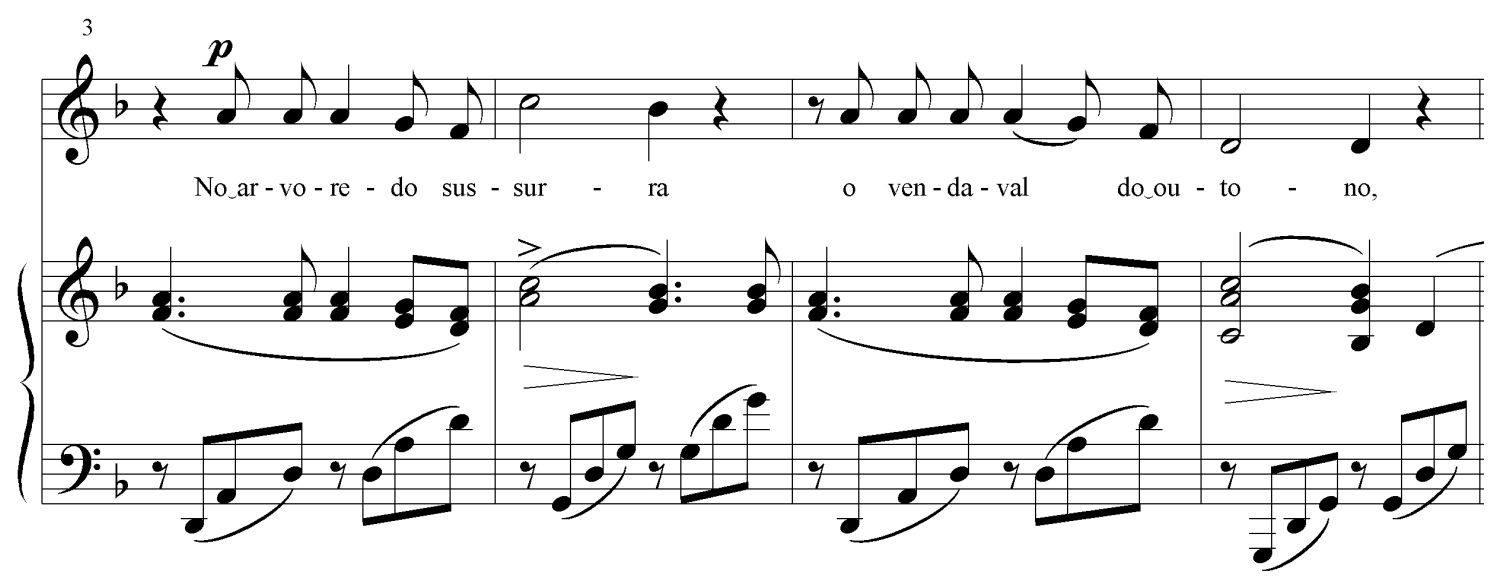

PIGNATARI, Dante (Ed.). Canções para voz e piano. São Paulo: EDUSP, 2004, p. 134.

A terceira canção do opus 21, Soneto, que ambienta um poema de Coelho Neto, o mesmo autor do libreto de Ártemis, incorpora a valsa, talvez pela primeira vez na canção brasileira. Não é necessário que nos estendamos aqui sobre a importância da valsa no cancioneiro popular, mas o ritmo vienense foi assimilado e incorporado na música brasileira 
justamente sob a forma de canção, e não como dança, e talvez esteja aqui o ponto crucial do processo de abrasileiramento da música européia: a flexão a que o idioma submete a linguagem musical estrangeira. Foi essa relação íntima existente entre música e língua que Nepomuceno identificou e aplicou com consciência e maestria em suas canções. Em Soneto, o acompanhamento é composto de arpejos descarnados e translúcidos e, sozinho, em nenhum momento lembra uma valsa. A melodia cantada, apoiando-se no primeiro tempo dos compassos ternários, é que está em tempo de valsa, o tempo sentimental e lírico característico da valsa brasileira (a indicação de caráter é Com ternura):

EXEMPLO 85: A. NEPOMUCENO. Soneto, c. 1-8
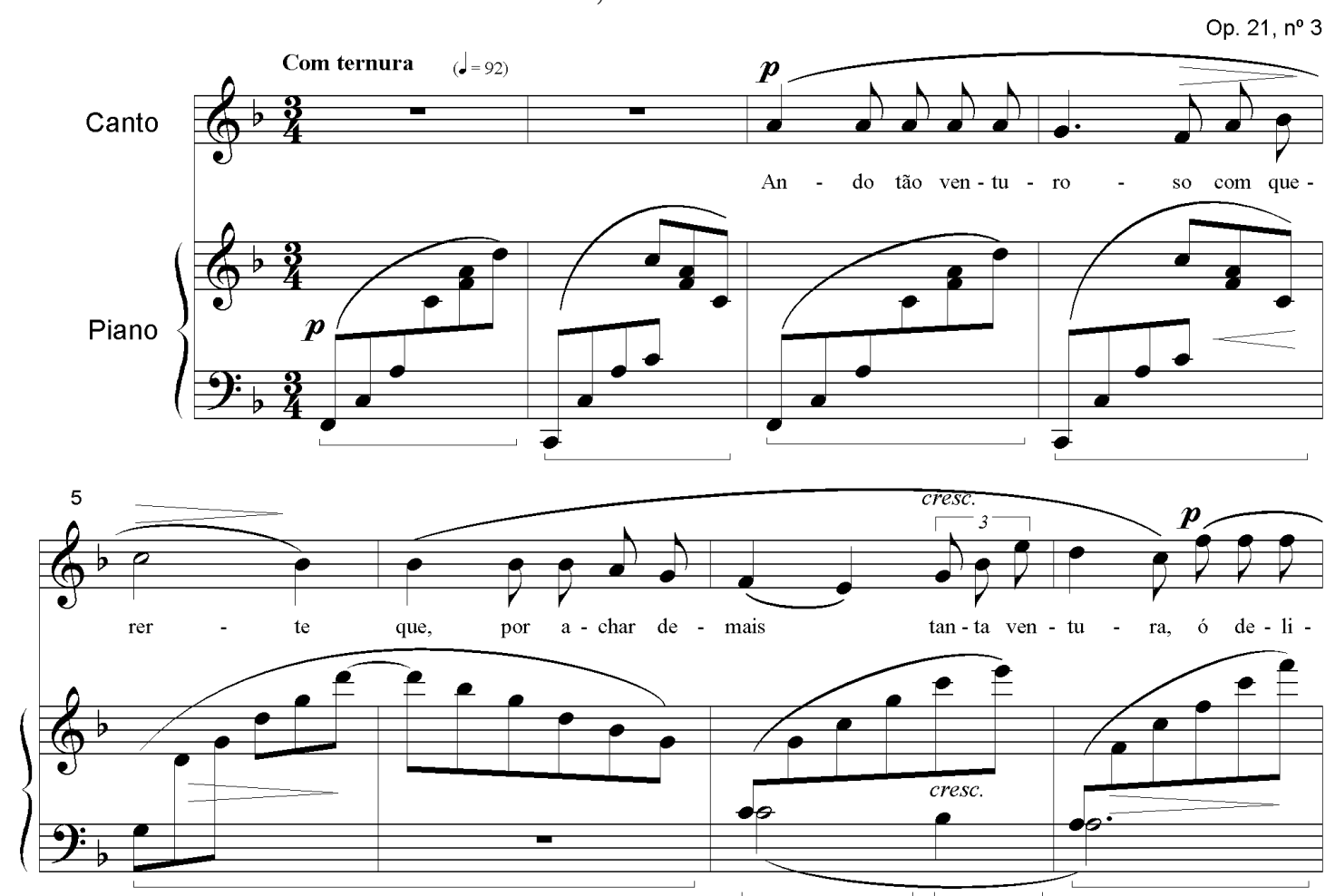

PIGNATARI, Dante (Ed.). Canções para voz e piano. São Paulo: EDUSP, 2004, p. 166.

As canções do opus 26, Turquesa e Hidrófana, sobre poemas de Luís Guimarães Filho, também apresentam esse balanço brasileiro; ele aparece sob forma mais complexa na primeira, em que ao compasso 6/8 do acompanhamento se sobrepõe o compasso 2/4 da parte cantada, explorando a relação de 3 contra dois que já tínhamos visto em Xácara, opus $20 \mathrm{n}^{\circ} 1$ (ver capítulo anterior): 
EXEMPLO 86: A. NePOMUCENO. Turquesa, c. 1-6
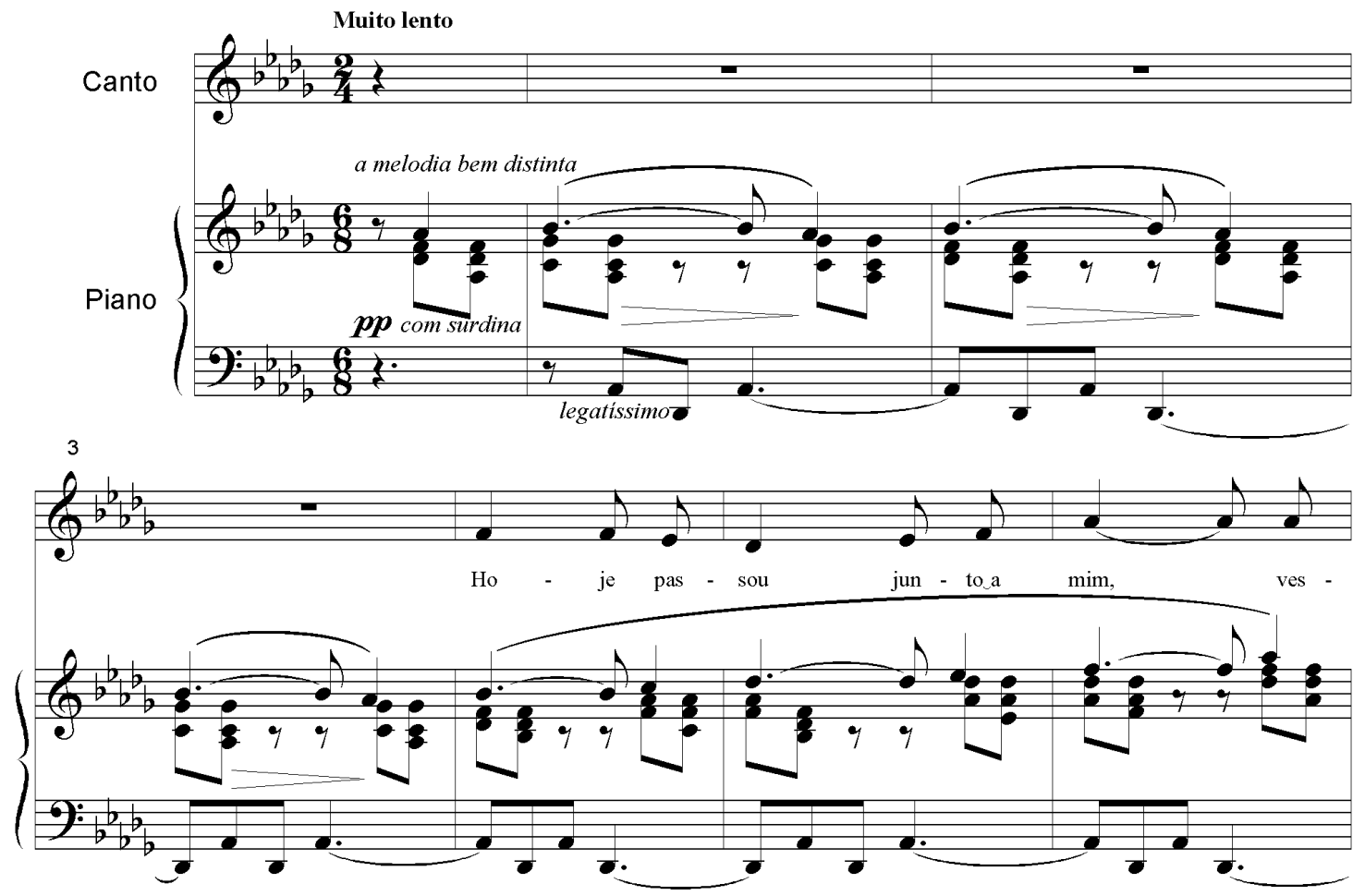

PIGNATARI, Dante (Ed.). Canções para voz e piano. São Paulo: EDUSP, 2004, p. 169.

Já Hidrófana explora o balanço manso do 6/8 das cantigas populares:

EXEMPLO 87: A. NEPOMUCENO. Hidrófana, c. 1-3

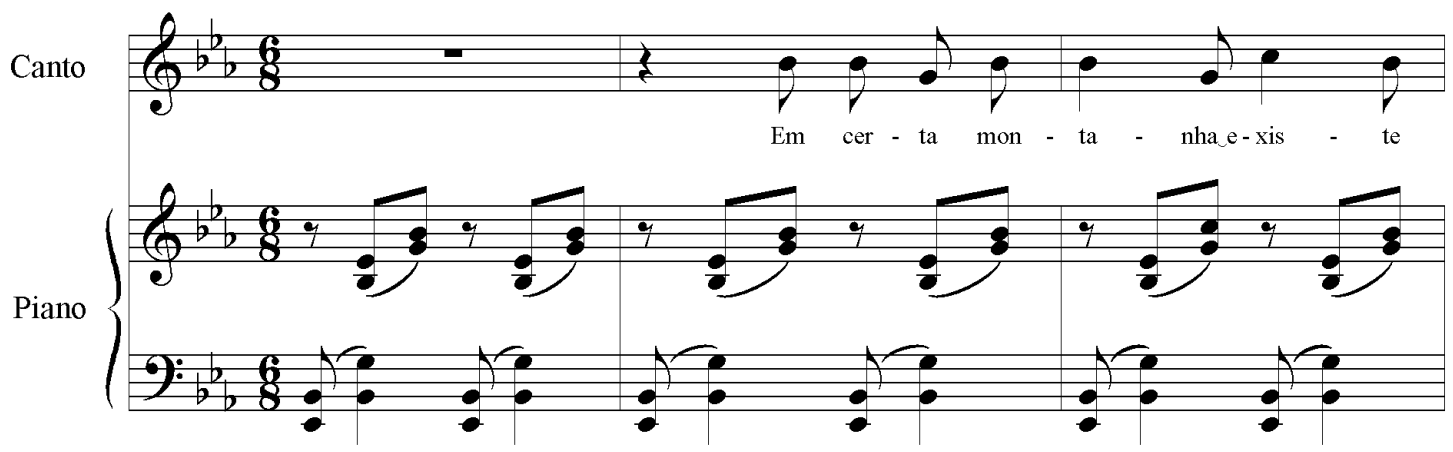

PIGNATARI, Dante (Ed.). Canções para voz e piano. São Paulo: EDUSP, 2004, p. 173.

Abaixo, dois exemplos do universo popular coletados por Mário de Andrade: 

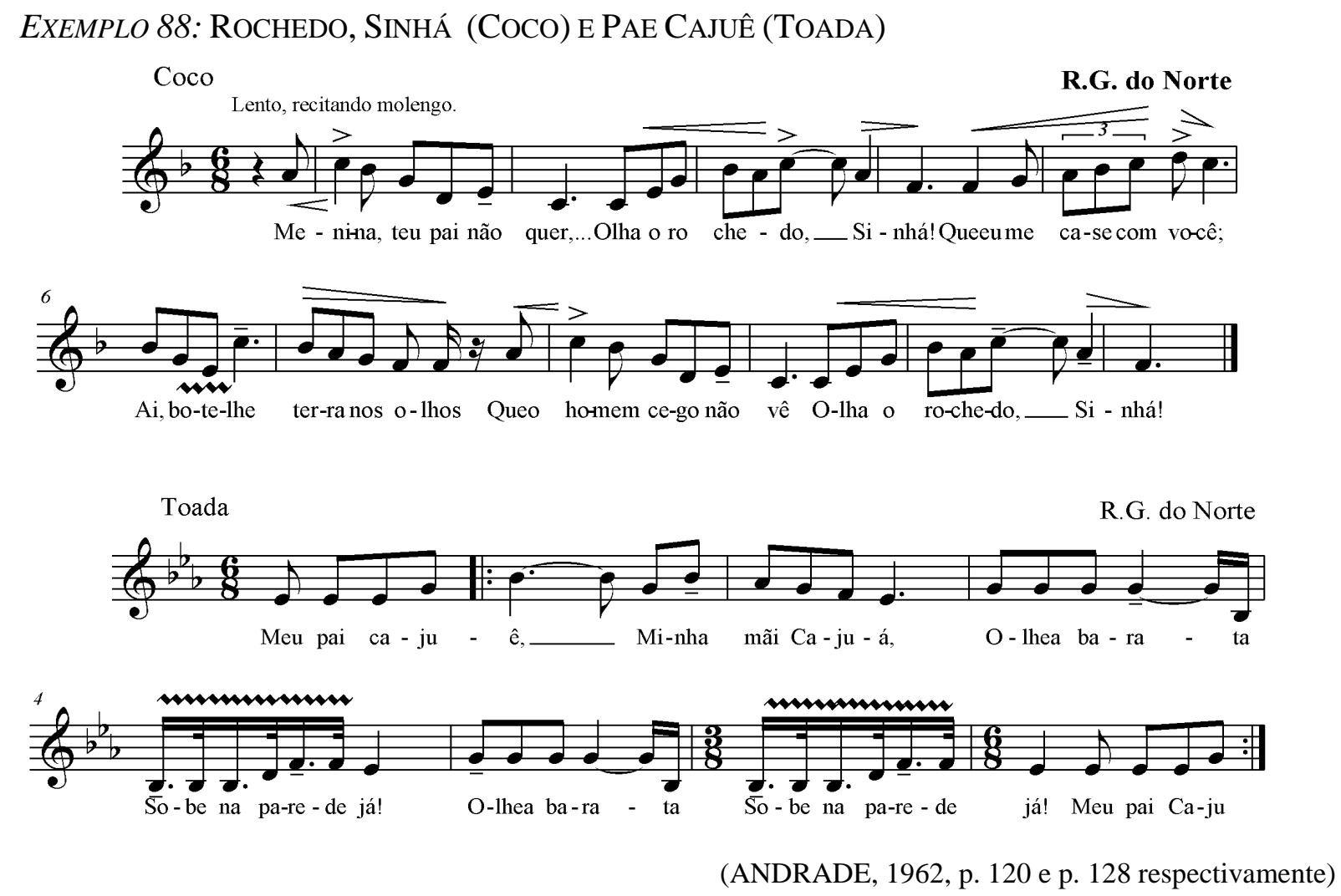

As duas canções do Opus 29, Trovas $I$ e $I I$, enfocam o universo popular de um outro ângulo, o dos gêneros, neste caso gêneros ibéricos. Por razões óbvias da formação do Brasil como nação, Portugal, mas também a Espanha, têm participação importante no imaginário cultural brasileiro e, consequentemente, na música nacional.

A primeira peça do par, com texto de Osório Duque Estrada, é um fado. Os arpejos violonísticos da introdução instrumental levam a um recitativo lamentoso que é acompanhado da forma mais simples possível por acordes no primeiro tempo de cada compasso; sua única função é dar sustentação harmônica à melodia: 
EXEMPLO 89: A. NEPOMUCENO. Trovas I, c. 1-8

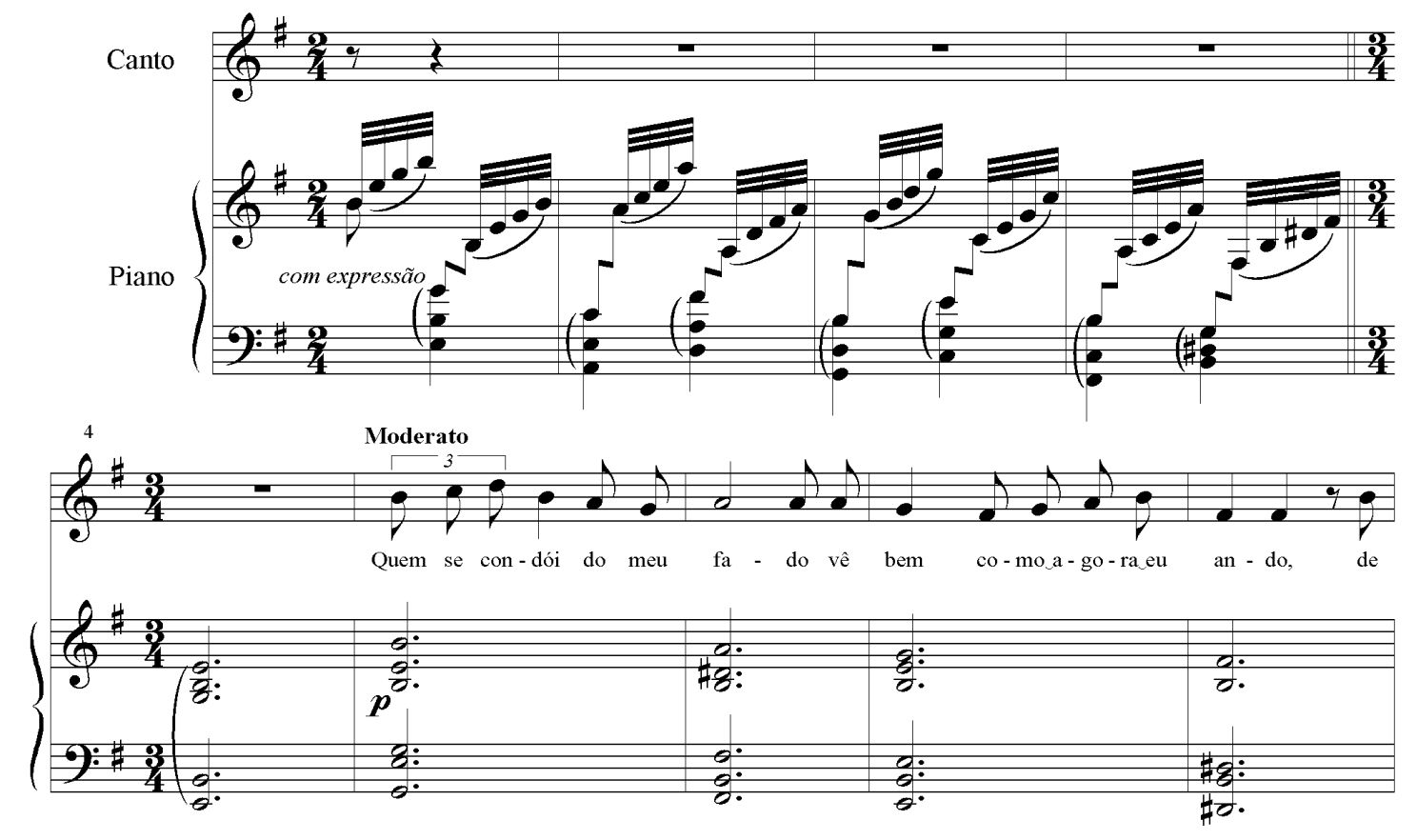

PIGNATARI, Dante (Ed.). Canções para voz e piano. São Paulo: EDUSP, 2004, p. 176.

Essa textura rarefeita do acompanhamento do primeiro período dá lugar à sonoridade verdadeiramente suntuosa do segundo, com oitavas nos baixos sustentadas pelo pedal, acordes nas duas mãos, e contracantos. Esse contraste de sonoridades é o recurso de que o compositor se vale para ambientar o contraste em que vive o poeta: de noite, sempre acordado, de dia sempre sonhando e querendo chorar, eu canto; querendo cantar, eu choro!: 
EXEMPLO 90: A. NEPOMUCENO. Trovas I, c. 12-21

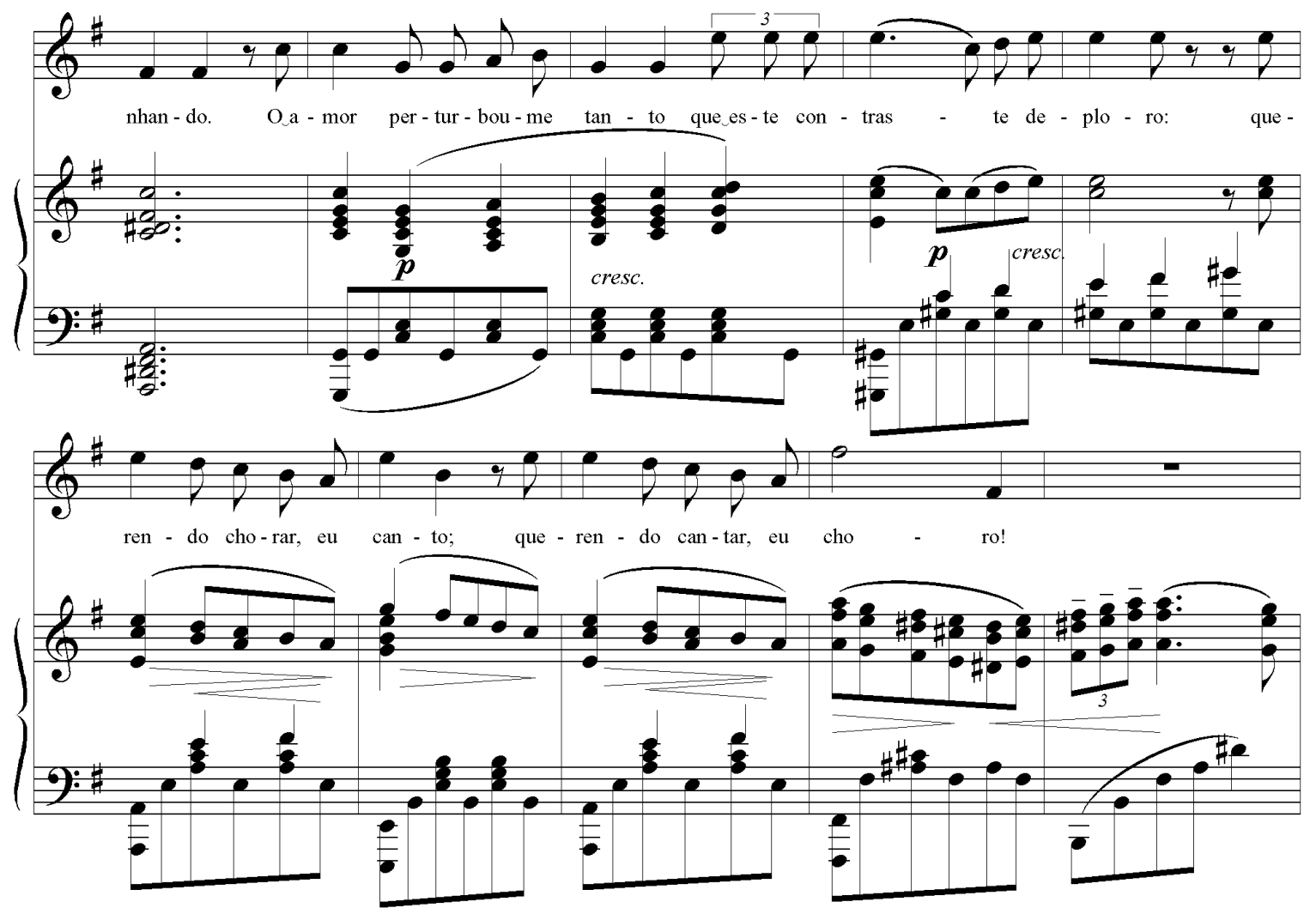

PIGNATARI, Dante (Ed.). Canções para voz e piano. São Paulo: EDUSP, 2004, p. 176-177.

O hibridismo que caracteriza as canções de Nepomuceno pode ser exemplificado por dois contracantos de Trovas I. Nos compassos 15-16, a escala em semínimas na parte da mão esquerda do piano se move por tons inteiros, mas o contexto harmônico é tão fortemente acentuado que este fragmento modal não é percebido como tal:

EXEMPLO 91: A. NePOMUCENO. Trovas I, c. 15-16

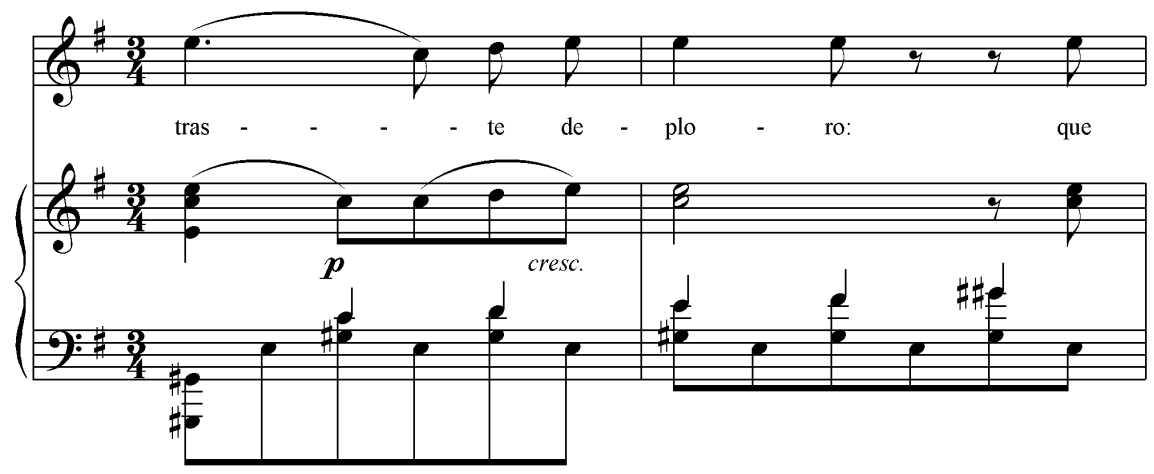

PIGNATARI, Dante (Ed.). Canções para voz e piano. São Paulo: EDUSP, 2004, p. 176. 
$\mathrm{Na}$ volta do recitativo inicial, Nepomuceno acrescenta um contracanto que é tocado em oitavas pelo piano:

EXEMPLO 92: A. NEPOMUCENO. Trovas I, c. 29-32

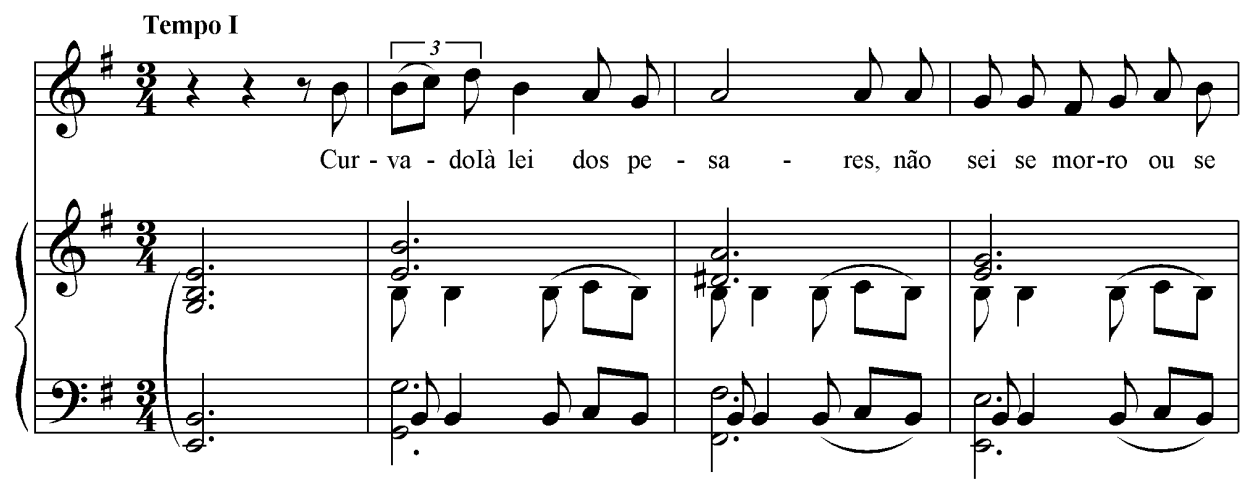

PIGNATARI, Dante (Ed.). Canções para voz e piano. São Paulo: EDUSP, 2004, p. 177.

Essa pulsação latejante do intervalo de semitom, que aqui acompanha as palavras curvado à lei dos pesares, não sei se morro ou se vivo, é uma herança da ópera italiana que surge com frequência na modinha luso-brasileira para caracterizar o lamento doloroso. Temos um exemplo na modinha anônima Hei de amar-te até morrer!:

EXEMPLO 93: ANÔNIMO. Hei de amar-te até morrer, c. 16-20
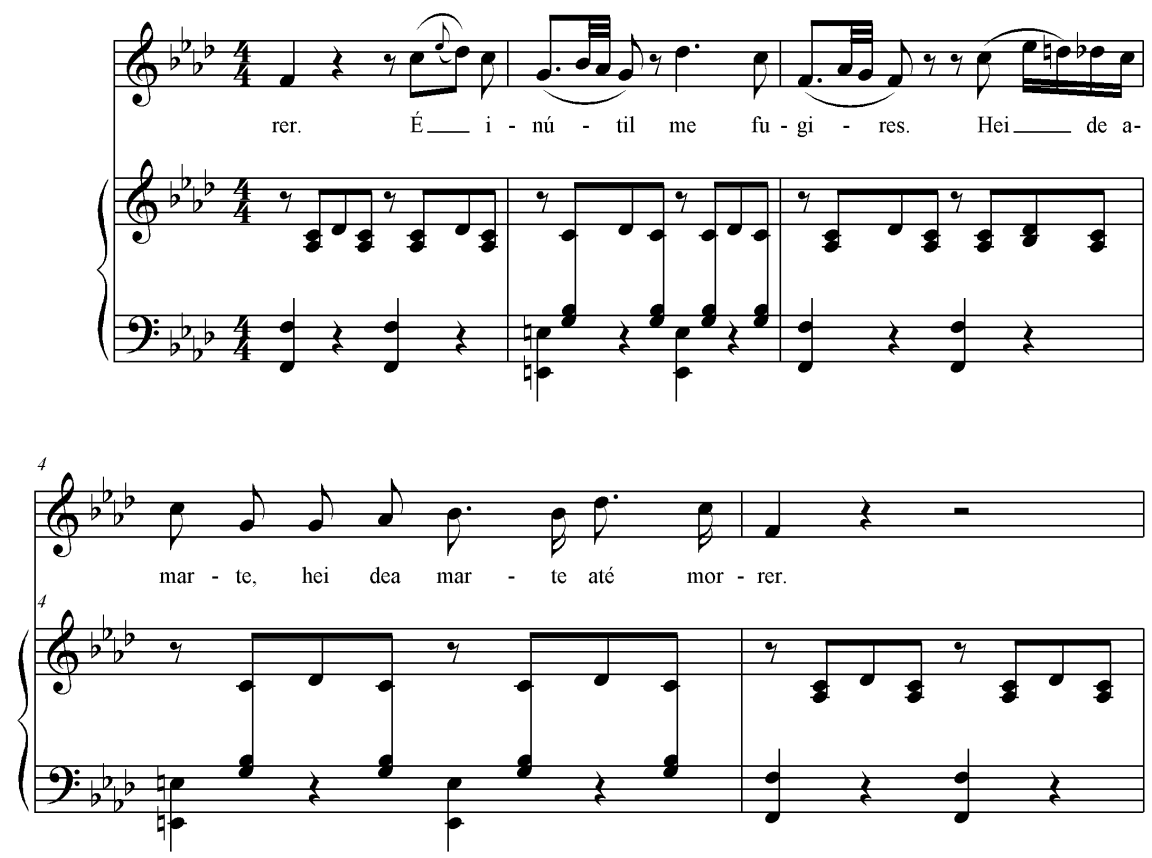

ANDRADE, Mário de (Ed.). Modinhas Imperiais. São Paulo: MARTINS,1930, p. 45-46. 
Trovas II, sobre poema de Magalhães Azeredo, é uma serenata irônica com ritmo espanhol. Isaac Albéniz (1860-1909) chama sua Cádiz, da Suíte Espanhola, que tem ritmo idêntico ao da canção de Nepomuceno, de "saeta", um dos inúmeros palos (= naipes), ou ritmos do flamenco:

EXEMPLO 94: I. ALBÉNIZ. Cádiz, c. 1-8
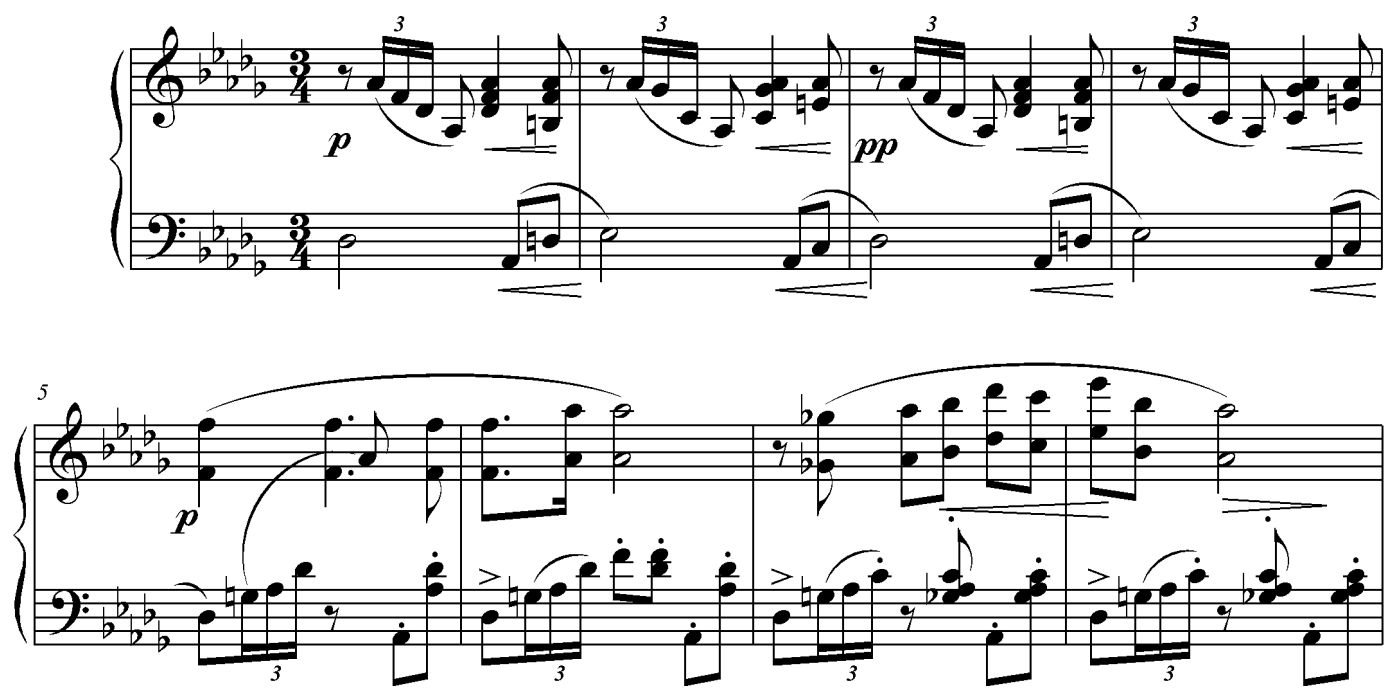

VELT, J. M. (Ed.). Cádiz (Saeta). From “Suite Espagnole”. Nova York: Edward B. Marks, 1938, p. 2.

Destaca-se a figura pianística que abre a peça, de natureza violonística como a da introdução de Trovas $I$, e que também conclui a canção, uma abertura típica na dominante e que ilustra, primeiro, os passos da menina que acorre à janela ao ouvir o som do violão e, no final, seu retorno à cama ao ser informada de que a serenata não é para ela: 
EXEMPLO 95: A. NePOMUCENO. Trovas II, c. 1-6

Op. $29, \mathrm{n}^{\circ} 2$

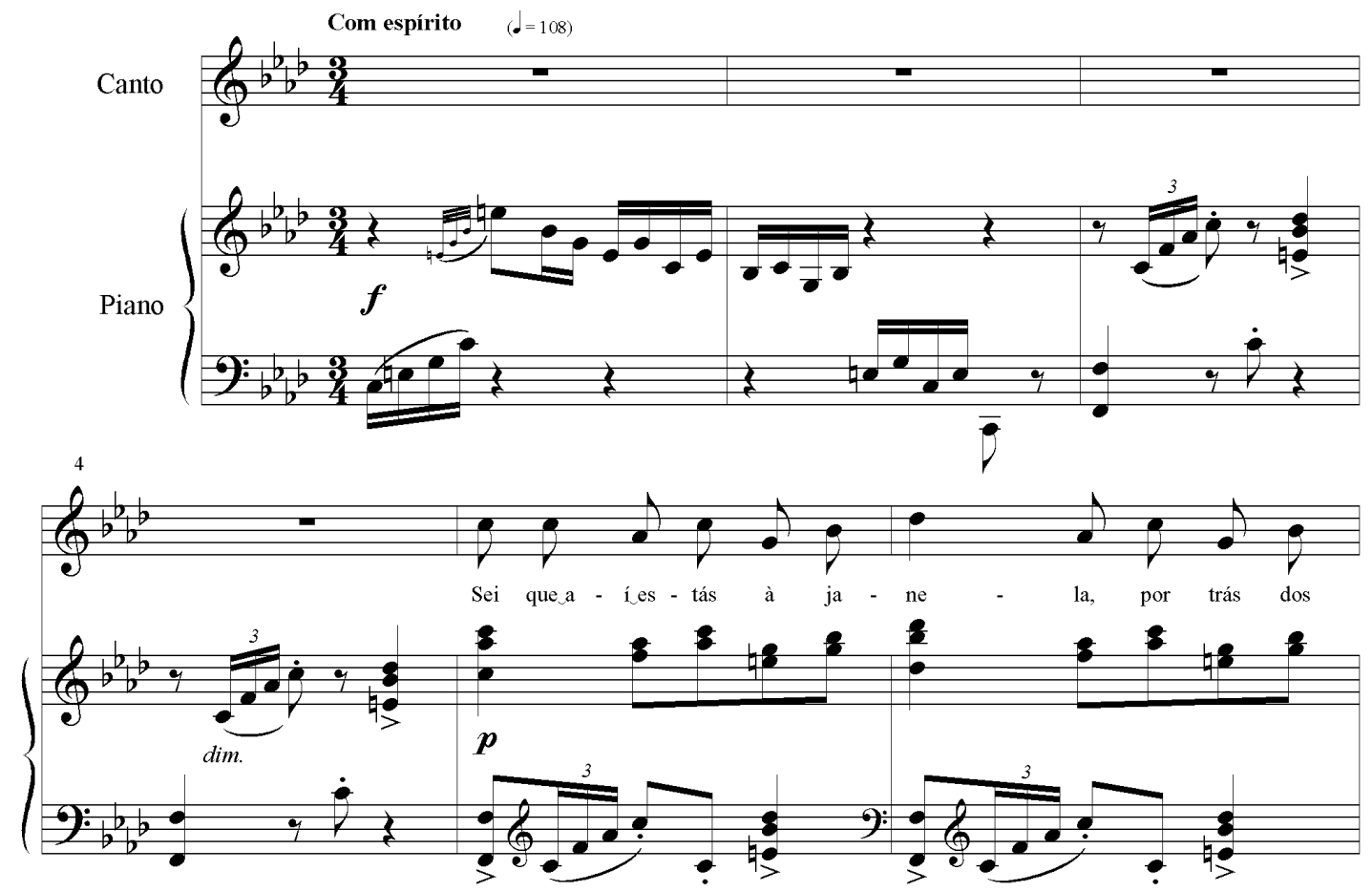

PIGNATARI, Dante (Ed.). Canções para voz e piano. São Paulo: EDUSP, 2004, p. 179.

EXEMPLO 96: A. NEPOMUCENO. Trovas II, c. 38-40

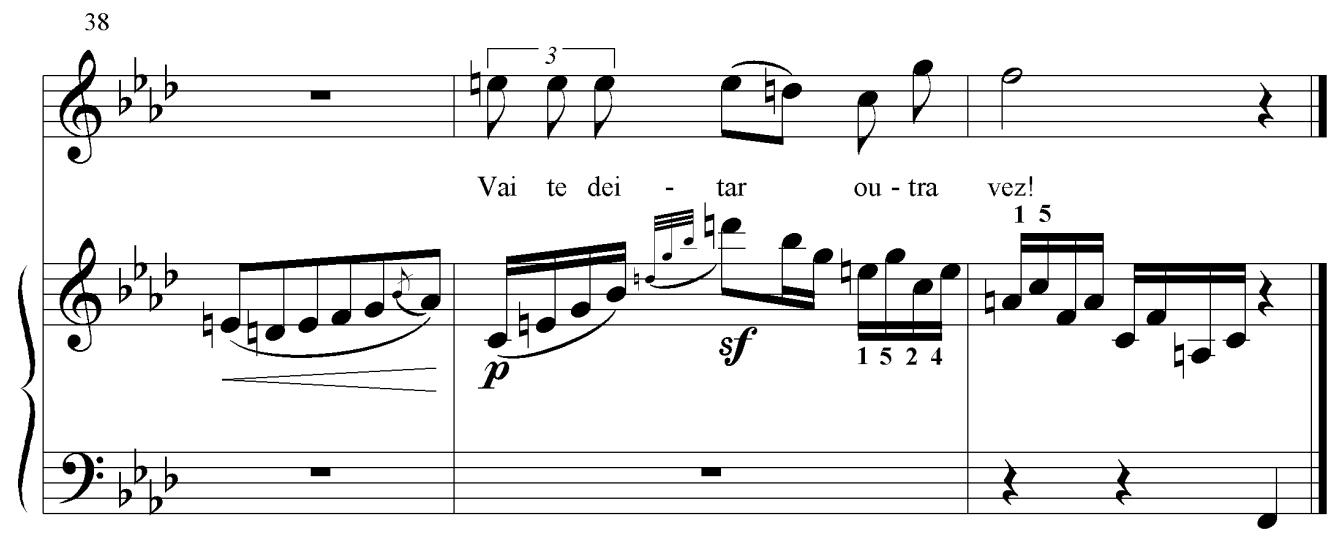

PIGNATARI, Dante (Ed.). Canções para voz e piano. São Paulo: EDUSP, 2004, p. 181. 
Segundo o CG, apenas duas canções foram compostas por Nepomuceno em 1902, ambas publicadas sem número de opus. Cantigas, sobre texto de Branca de Gonta Colaço, é uma das raras incursões explícitas do compositor no universo popular (a indicação de caráter é Em tom popular). Talvez ainda sob a inspiração que o levou a escrever as Trovas, Cantigas é uma síntese inequivocamente brasileira das influências ibéricas manifestas no Opus 29 com aquelas africanas que integram as raízes da música nacional. Embora pianístico por excelência, a textura e as figurações do acompanhamento são bastante típicas do violão.

Herança ibérica, a família das guitarras em geral, mas especialmente o violão de seis cordas, foi adotada de maneira generalizada no Brasil como o instrumento por excelência no acompanhamento da canção popular. A hipótese do caráter violonístico do acompanhamento de Cantigas é reforçada pela informação de que a canção foi publicada em suplemento musical da revista Renascença com o título A Guitarra (CORRÊA, 1996, p. 47). Este título somente pode referir-se ao caráter do acompanhamento, já que não há qualquer referência ao instrumento, nem mesmo implícita, como em Trovas II, por exemplo, que ao ambientar uma serenata feita sob a janela, dá a entender que o cantor se acompanha ao violão.

Cantigas se destaca no cancioneiro de Nepomuceno sobretudo pela complexidade rítmica. A base, na parte da mão esquerda do piano, é uma variação do ritmo de habanera (ver Cap. 11, p. 91). A última nota da figuração arpejada da mão direita, ao se prolongar sobre a primeira semicolcheia do compasso seguinte, fornece a síncopa característica. A subdivisão dos tempos nas duas partes do piano é quaternária. A esse acompanhamento, já por si bastante complexo, sobrepõe-se a parte da voz, onde os tempos são subdivididos basicamente em tercinas. O contraponto rítmico é semelhante ao de Xácara, só que mais complexo, disposto em três camadas que tensionam uma à outra. Essa complexidade rítmica, importada da África, une-se às características ibéricas presentes na textura do acompanhamento e nos contornos melódico-harmônicos, que sempre deixam perceber o chiaroscuro agridoce da modinha ancestral: 
EXEMPLO 97: A. NEPOMUCENO. Cantigas, c. 1-8

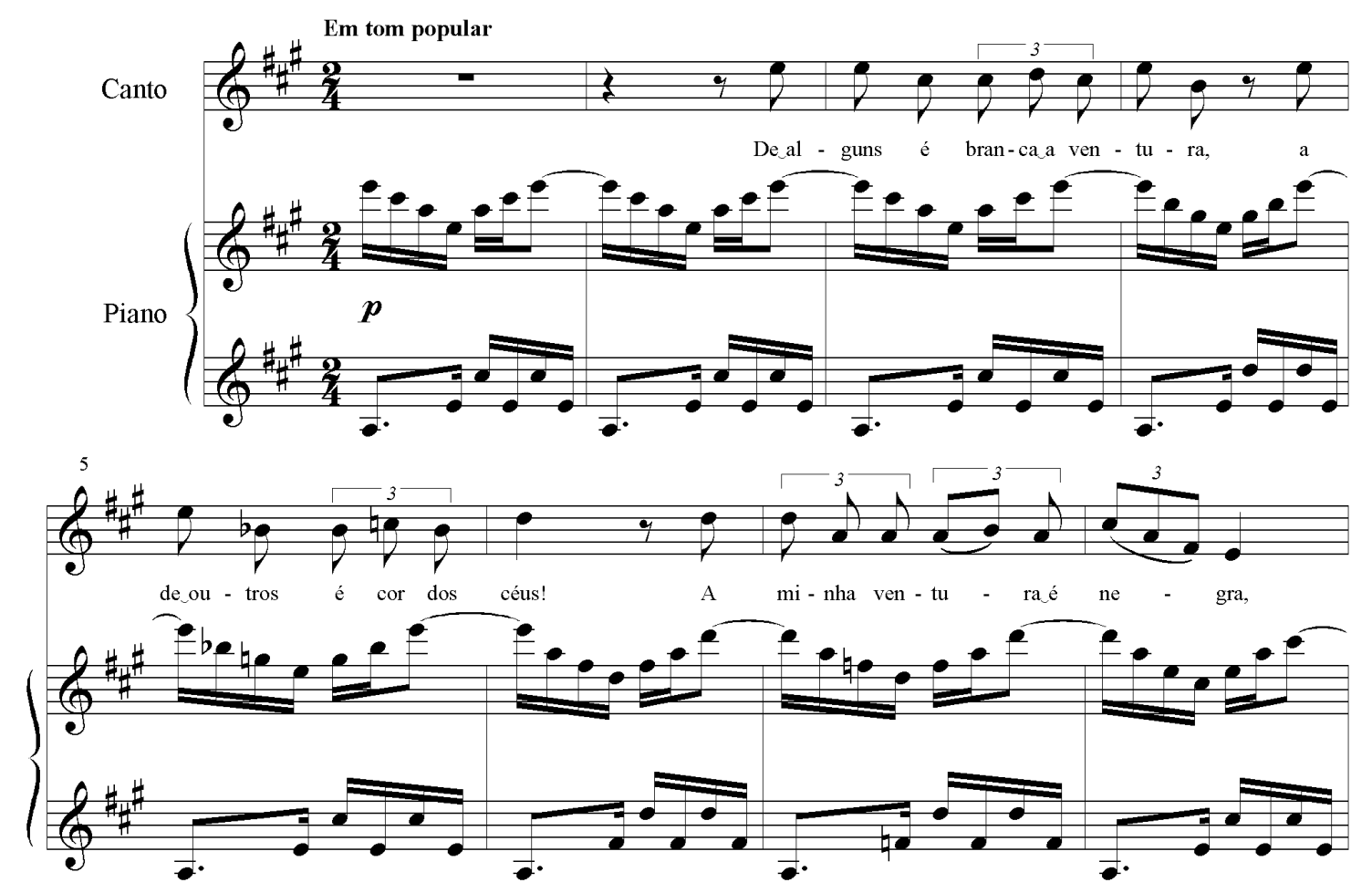

PIGNATARI, Dante (Ed.). Canções para voz e piano. São Paulo: EDUSP, 2004, p. 182.

Cantilena, a outra canção produzida em 1902, contrasta fortemente com Cantigas. Conhecendo a tendência do compositor de unir suas canções em pares contrastantes, poderíamos perfeitamente ter aqui mais um desses pares. Seja como for, a ambientação do texto de Coelho Neto é de uma simplicidade rítmica quase espartana, baixos e acordes numa espécie de marcha lenta em compasso quaternário. Cantilena enquadra-se no grupo das canções que misturam diversos elementos da música européia e que, utilizando a língua como catalizador, extrái do amálgama música brasileira: 
EXEMPLO 98: A. NEPOMUCENO. Cantilena, c. 1-7
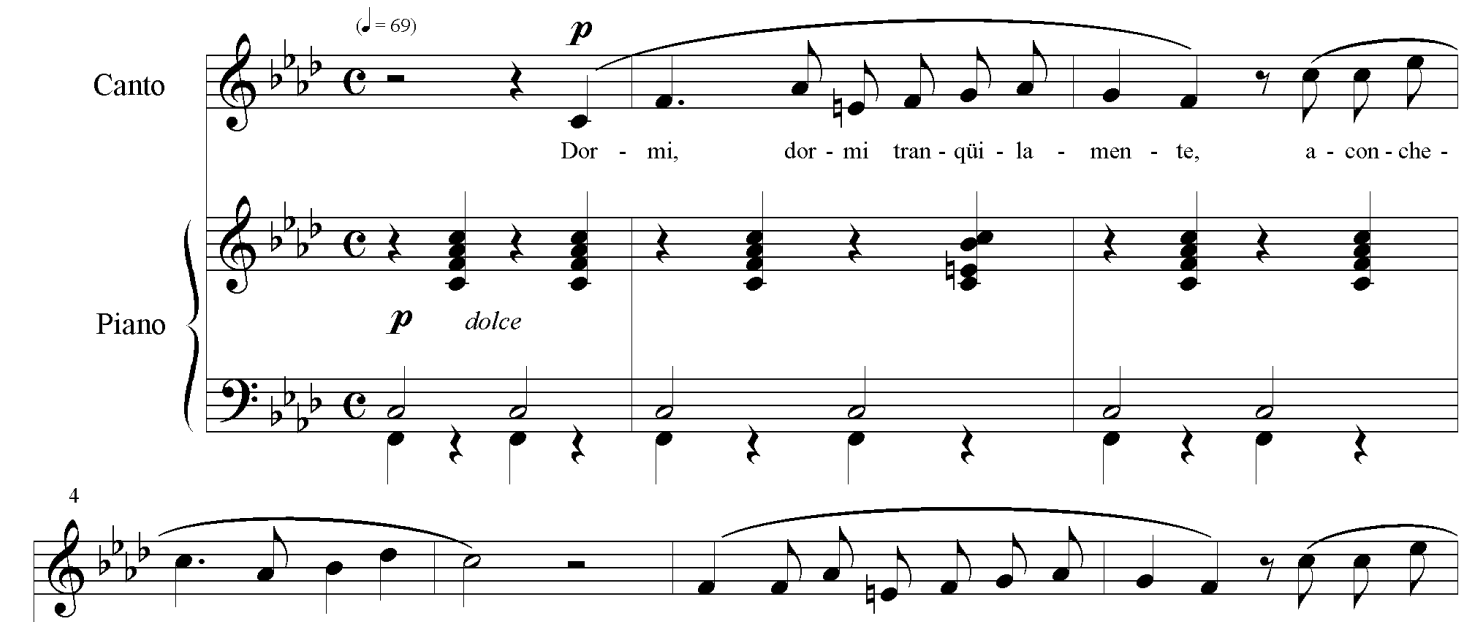

ga - do ao meu a - mor

ten - des no co-lo um ni - nho quen - te on - de_a-cha -

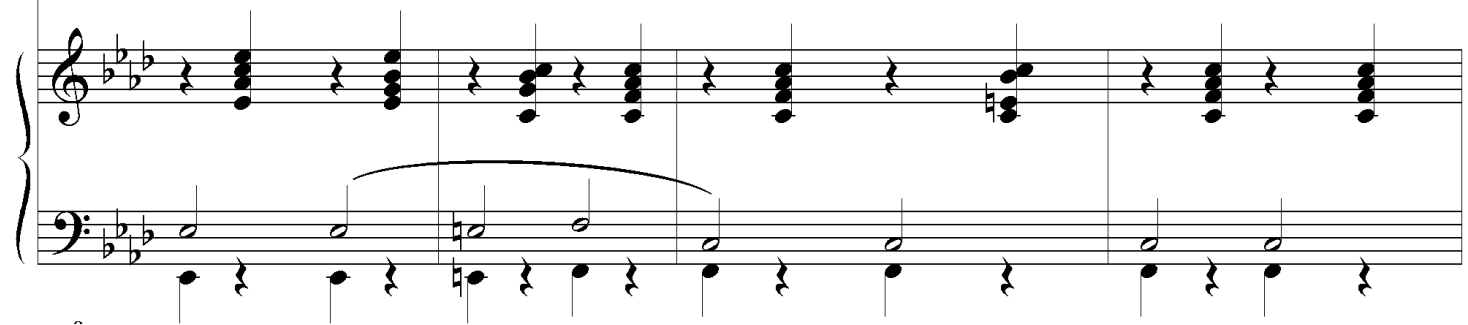

PIGNATARI, Dante (Ed.). Canções para voz e piano. São Paulo: EDUSP, 2004, p. 187.

No caso de Cantilena, a sonoridade indefinivelmente ibérica é muito forte, talvez uma reverberação das criações anteriores. Os arquétipos dessa melódica ibérica, que contamina toda a música brasileira, podem ser traçados a partir dos cantos populares. Mário de Andrade, em seu Ensaio sobre a música brasileira, registra um canto religioso de São Paulo, Coração Santo, que apesar da fórmula de compasso diferente (6/8, e não 3/4 como registrou Mário de Andrade), exibe um parentesco inegável com a melodia de Cantilena:

\section{EXEMPLo 99: ANÔNIMO. Coração Santo}
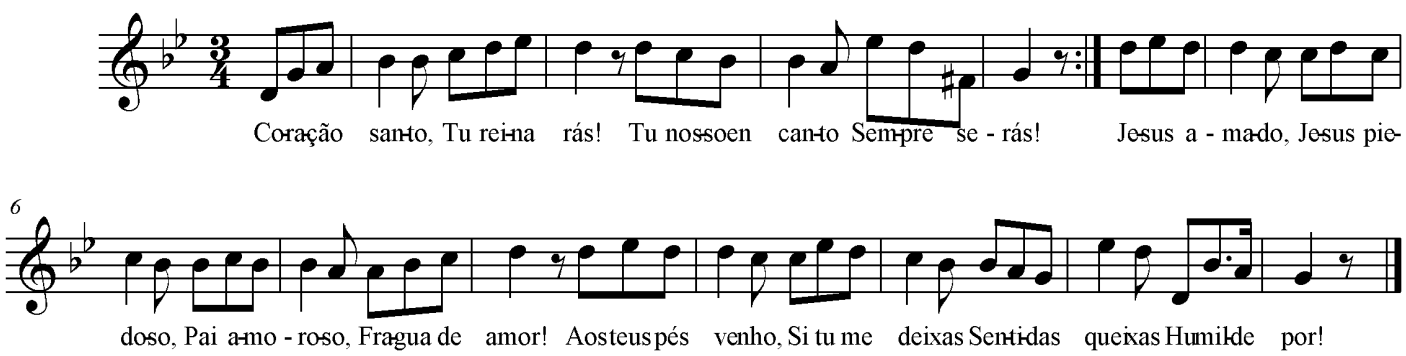

(ANDRADE, 1962, p. 103) 


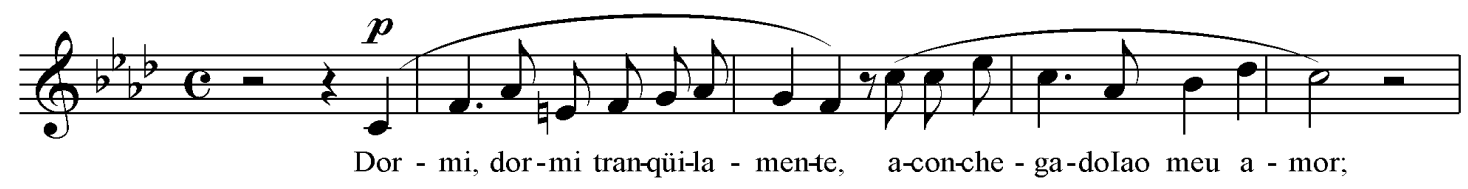

PIGNATARI, Dante (Ed.). Canções para voz e piano. São Paulo: EDUSP, 2004, p. 187.

O ano de 1903 verá sair da pluma de Nepomuceno quatro canções, publicadas em pares com os números de opus 30 e 31 respectivamente. A primeira do Opus 30, Coração indeciso, sobre poema de Frota Pessoa, é um exemplo de como Nepomuceno se apropria dessa melódica herdada principalmente dos portugueses e a transforma, tratando-a com procedimentos próprios da música culta européia. O primeiro período, e mais ainda a primeira metade do segundo, quase poderiam estar presentes em alguma coletânea de música popular brasileira tradicional:

EXEMPLO 101: A. NePOMUCENO. Coração indeciso, Op. 30 nº 1, c. 1-7
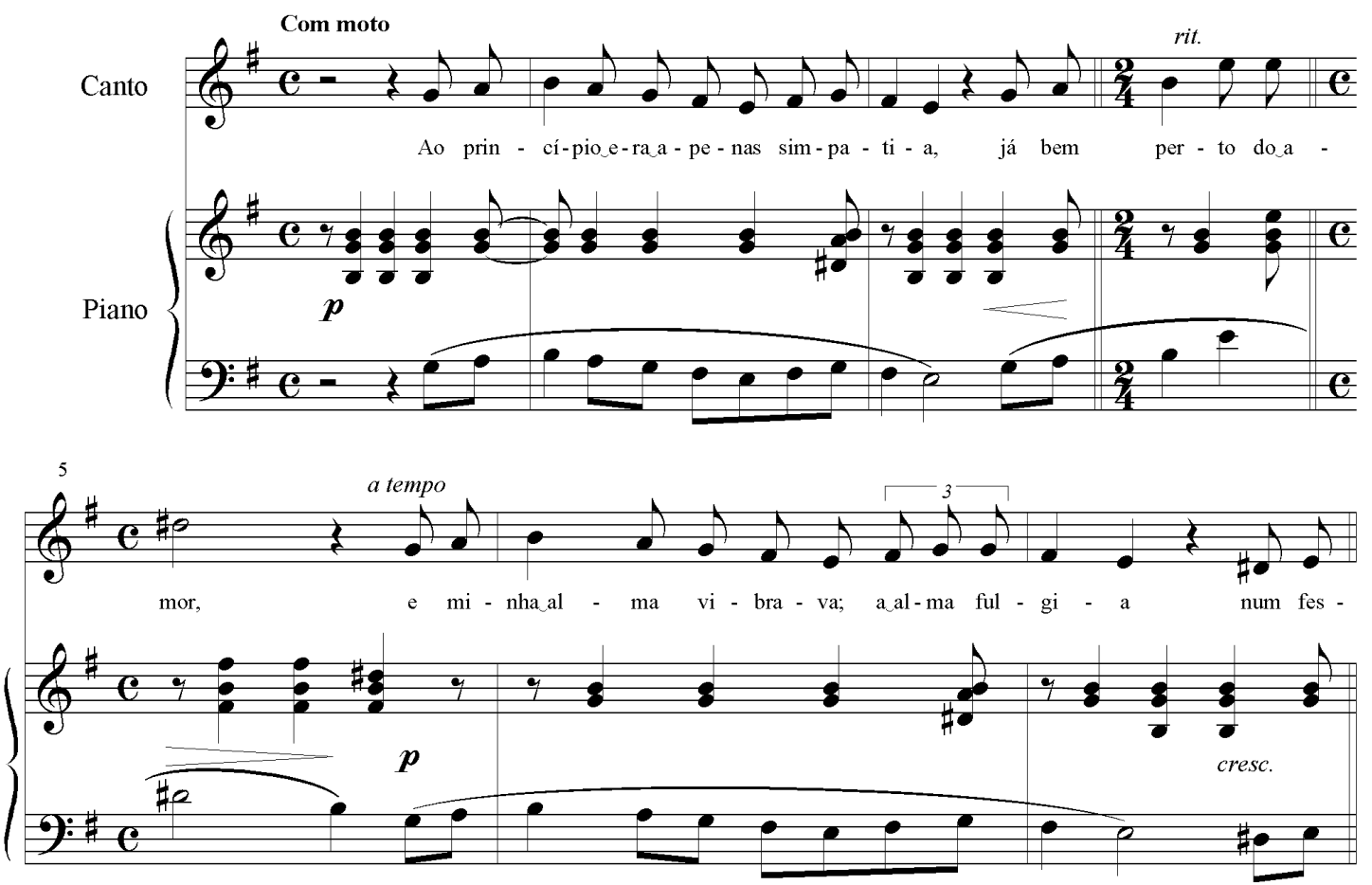

PIGNATARI, Dante (Ed.). Canções para voz e piano. São Paulo: EDUSP, 2004, p. 190. 
Já na segunda frase do segundo período, com o cromatismo descendente da parte cantada (compassos 13-15) e ascendente nos acordes do piano (compassos 15-17), o compositor se vale de uma progressão harmônica que, bastante comum na música erudita européia do século XIX, permaneceu estranha ao universo popular:

EXEMPLo 102: A. NePOMUCENo. Coração indeciso, Op. 30 nº 1, c. 13-17

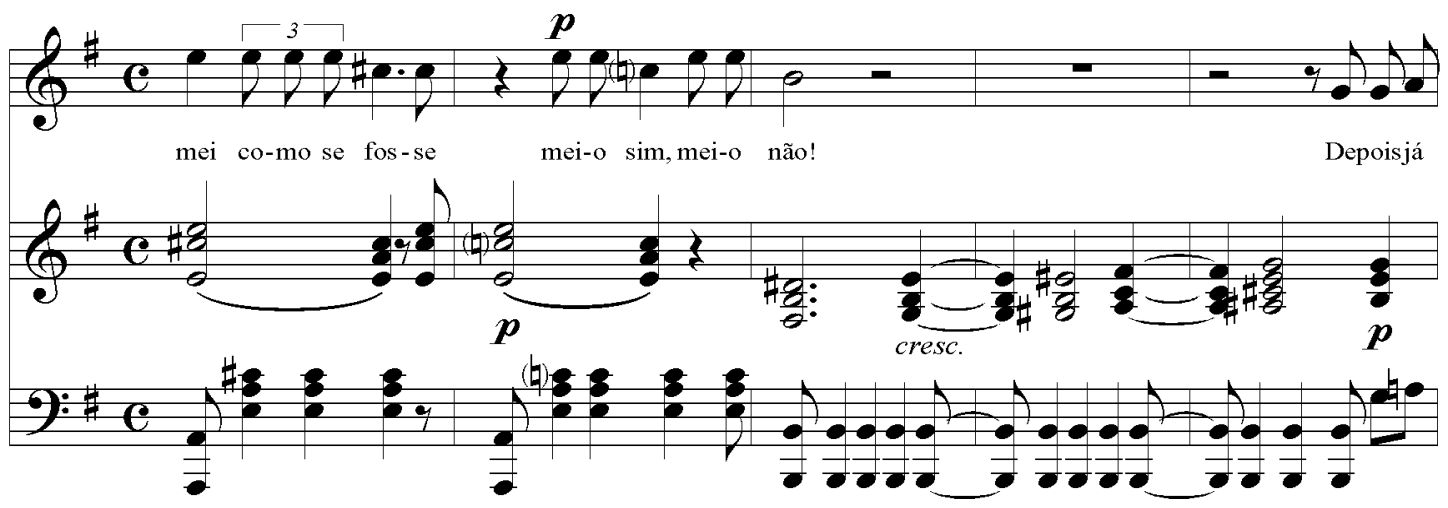

PIGNATARI, Dante (Ed.). Canções para voz e piano. São Paulo: EDUSP, 2004, p. 190-191.

Em Canção, Op. 30 n 2 2, ao contrário, os gestos rítmico-melódicos grandiloquentes e retóricos, adequados ao tom dos versos de Fontoura Xavier, são exclusivos do universo erudito. O acompanhamento instrumental muda a cada estrofe: tercinas em contratempo para a terra, arpejos de grande envergadura (ondas) nos registros grave e médio para o oceano, acordes arpejados em semicolcheias, em modo maior (a canção está em sol menor), para o céu estrelado, e outro lugar comum do lied, acordes repetidos em sextinas, para a paixão: 
EXEMPLO 103: A. NePOMUCENO. Canção, Op. 30 nº 2, c. 1-4, 15-18, 29-32 e 41-44
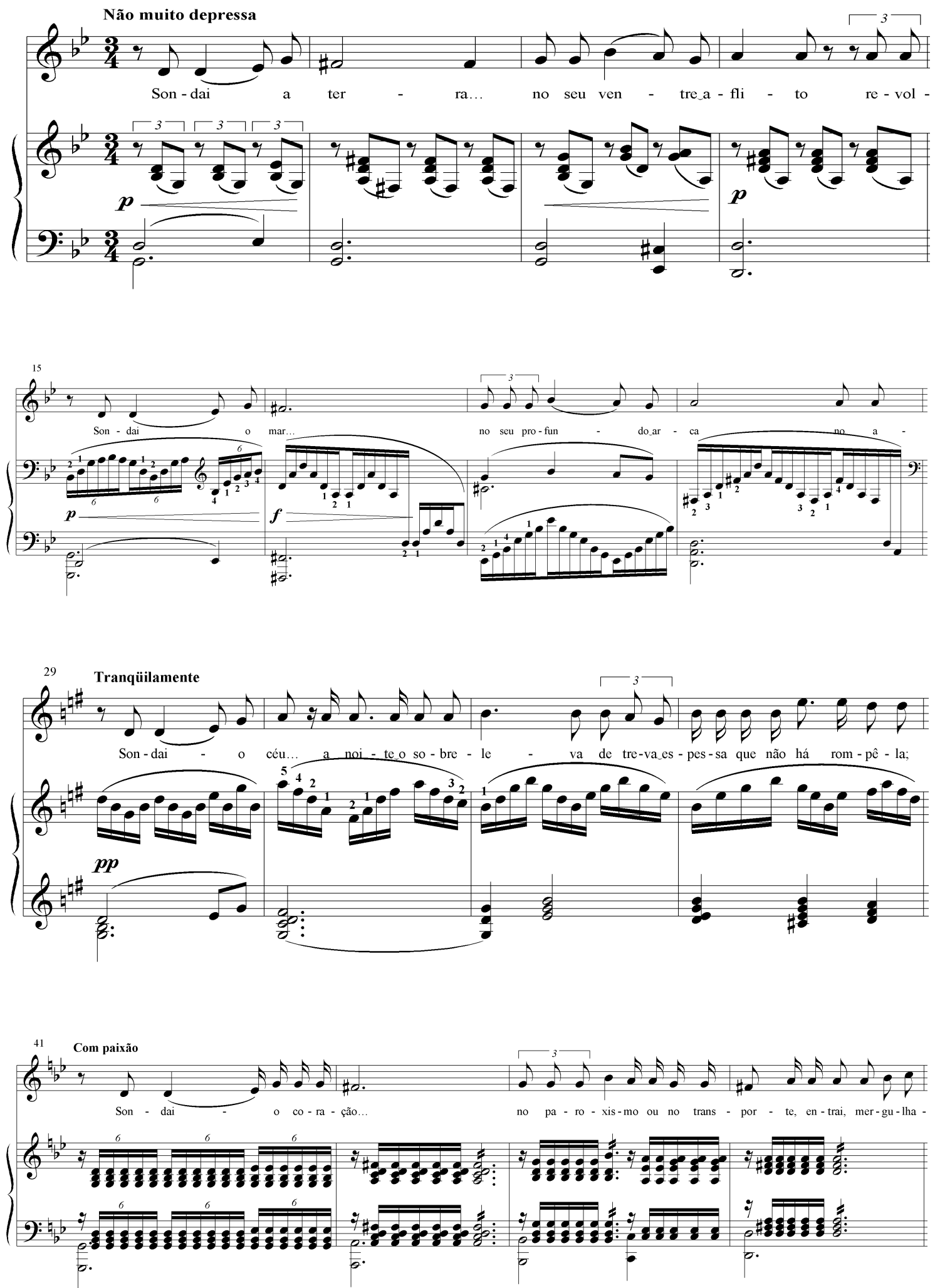

PIGNATARI, Dante (Ed.). Canções para voz e piano. São Paulo: EDUSP, 2004, p. 193, 194, 195 e 196 respectivamente. 
As canções do Opus 31, assim como os dois pares de canções compostos em 1904 e publicados como Opus 32 e 34, inserem-se naquele que chamei de estilo pessoal do compositor. Nada as distingue como brasileiras além dos textos ambientados. Na parte vocal das peças, Nepomuceno desenvolve o que chamo de "recitativo brasileiro", ou seja, melodias de origem européia flexionadas pelo idioma. Embora não deva nada ao folclore nacional, a música acolhe os poemas com naturalidade. Todas as peças se inscrevem na linguagem do romantismo característico do estilo de Nepomuceno. Ouvem-se ecos de Chopin na primeira canção do opus 31, A grinalda, sobre texto de Carlos Magalhães Azeredo, onde a figura do acompanhamento reproduz quase literalmente a primeira metade do tema principal da Polonaise-Fantaisie, op. 61 do compositor polonês, tal como aparece na coda da peça, na mão esquerda, em oitavas:

EXEMPLO 104: A. NEPOMUCENO. A grinalda, Op. 31 n $^{\circ} 1$, c. 1-3

Op. $31, n^{\circ} 1$

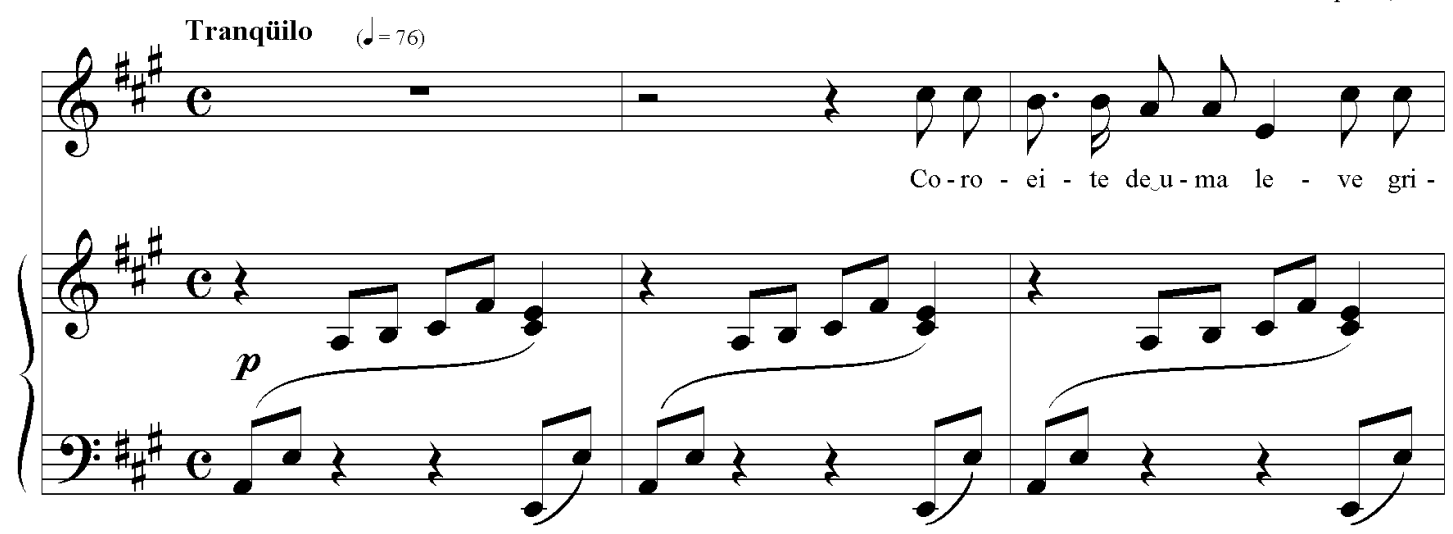

PIGNATARI, Dante (Ed.). Canções para voz e piano. São Paulo: EDUSP, 2004, p. 198.

EXEMPLO 105: F. CHOPIN. Polonaise-Fantaisie, Op. 61, c. 254-255

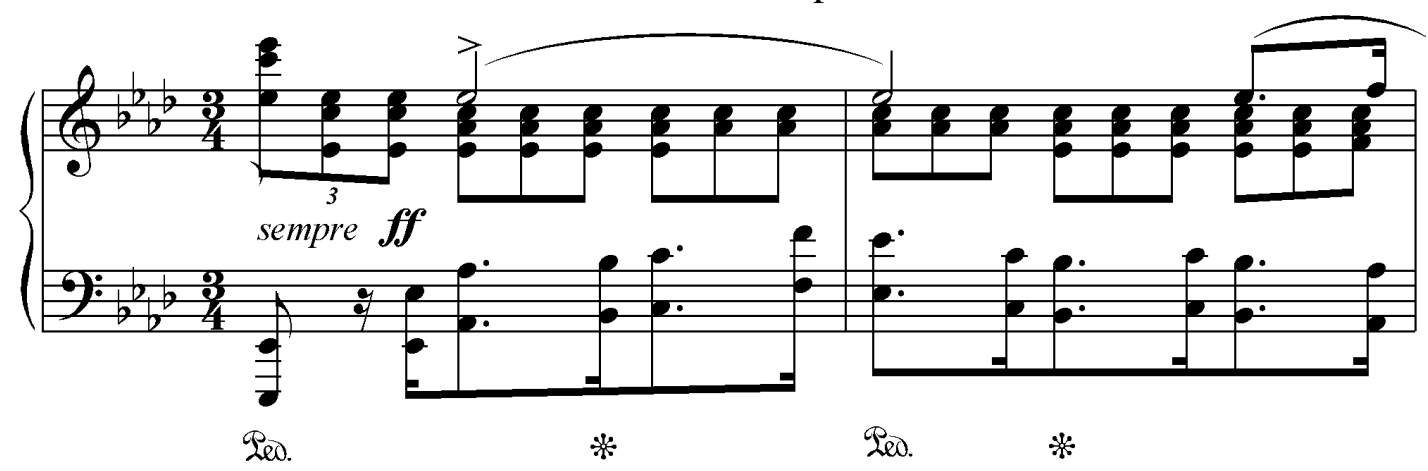

ZIMMERMANN, Ewald (Ed.). Fredéric Chopin: Polonaisen. Munique: G. Henle, 1972, p. 90. 
Já o acompanhamento da canção opus $32 \mathrm{n}^{\circ} 1$, Sempre!, que ambienta poema de Affonso Celso, nos traz à mente o caráter inquieto do Estudo opus $10 \mathrm{n}^{\circ}$ 9:

EXEMPLO 106: A. NePOMUCENO. Sempre!, Op. 32 nº 1, c. 1-2

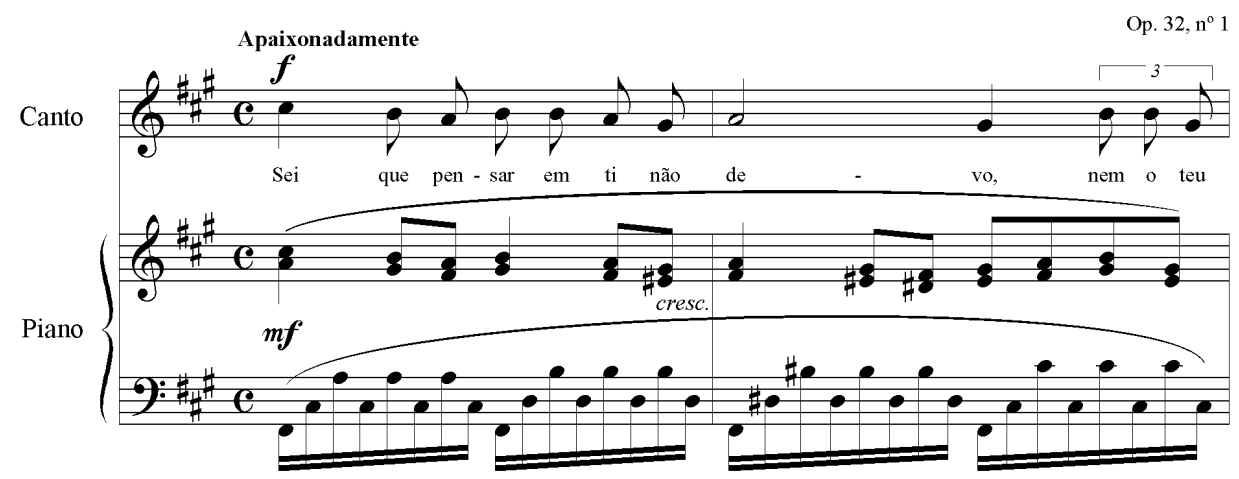

PIGNATARI, Dante (Ed.). Canções para voz e piano. São Paulo: EDUSP, 2004, p. 204.

EXEMPLO 107: F. CHOPIN. Estudo Op. $10 n^{\circ}$ 9, c. 1-4

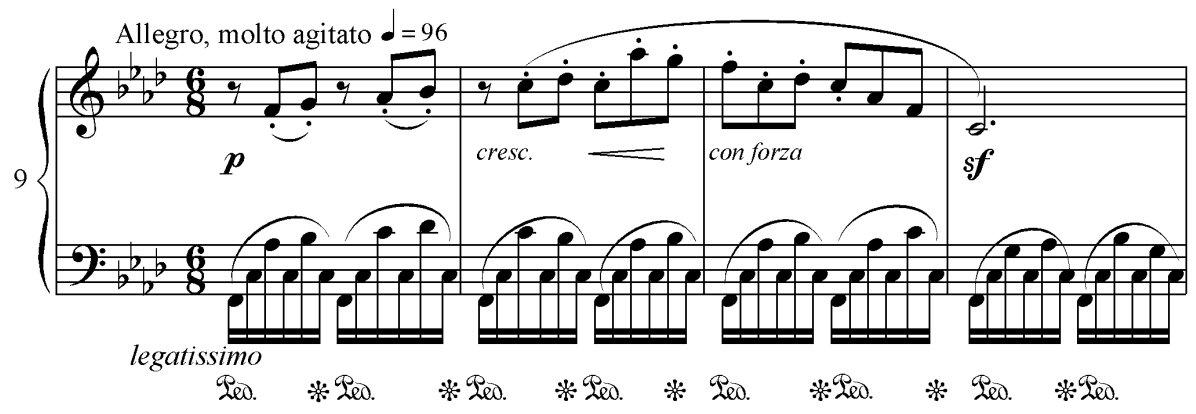

PADEREWSKI, I. (Ed.). Fredéric Chopin: Studies. Cracóvia: Polish Music Publications, 1949, p. 45.

Sempre! nos traz também à lembrança o acompanhamento da canção opus $42 \mathrm{n}^{\circ} 7$ de Schumann:

EXEMPLO 108: R. SCHUMANN. An meinem Herzen, an meiner Brust, Op. 42 nº 7, c. 1-3

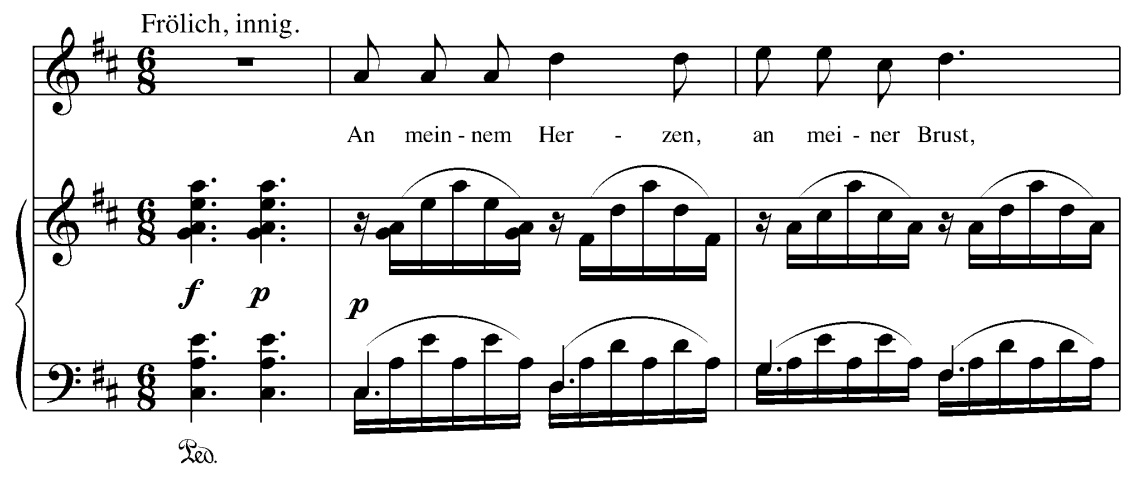

FRIEDLAENDER, M. (Ed.). Robert Schumann: Sämtliche Lieder. Leipzig: C. F. Peters, ca. 1900, p. 100. 
O acompanhamento instrumental das canções de número 2, tanto do opus 31 como do opus 32, Despedida e Dor sem consolo, coincidem em constituir-se basicamente em acordes repetidos em contratempo com a melodia cantada:

EXEMPLO 109: A. NePOMUCENO. Despedida, Op. 31 nº 2, c. 1-3

Op. $31, n^{\circ} 2$

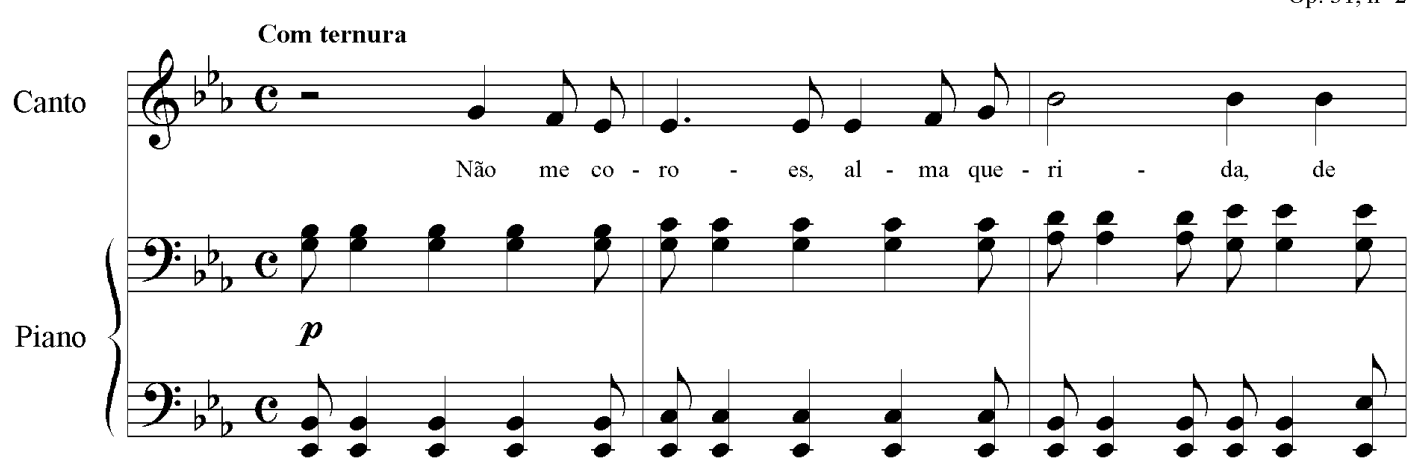

PIGNATARI, Dante (Ed.). Canções para voz e piano. São Paulo: EDUSP, 2004, p. 202.

EXeMPLO 110: A. NePOMUCENO. Dor sem consolo, Op. 32 n 2, c. 1-5

Op. $32, n^{\circ} 2$

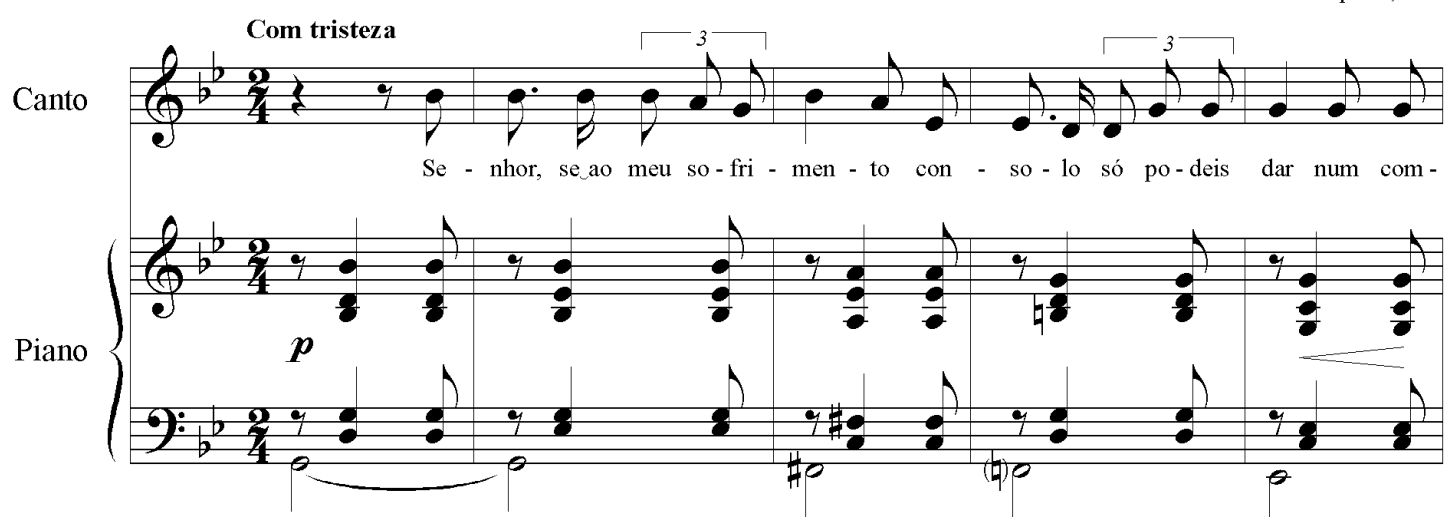

PIGNATARI, Dante (Ed.). Canções para voz e piano. São Paulo: EDUSP, 2004, p. 208.

O marco de referência mais importante para todo esse grupo de canções é sem dúvida nenhuma o lied. Este deslocamento dos acentos, que Nepomuceno utiliza com muita frequência, é muito raro na canção alemã. $O$ exame de dezenas de canções de Schubert e Schumann nos forneceu um único exemplo do último, e nenhum do primeiro: 
EXEMPLO 111: R. SCHUMANN. Intermezzo, Op. $39 n^{\circ}$ 2, c. 1-3

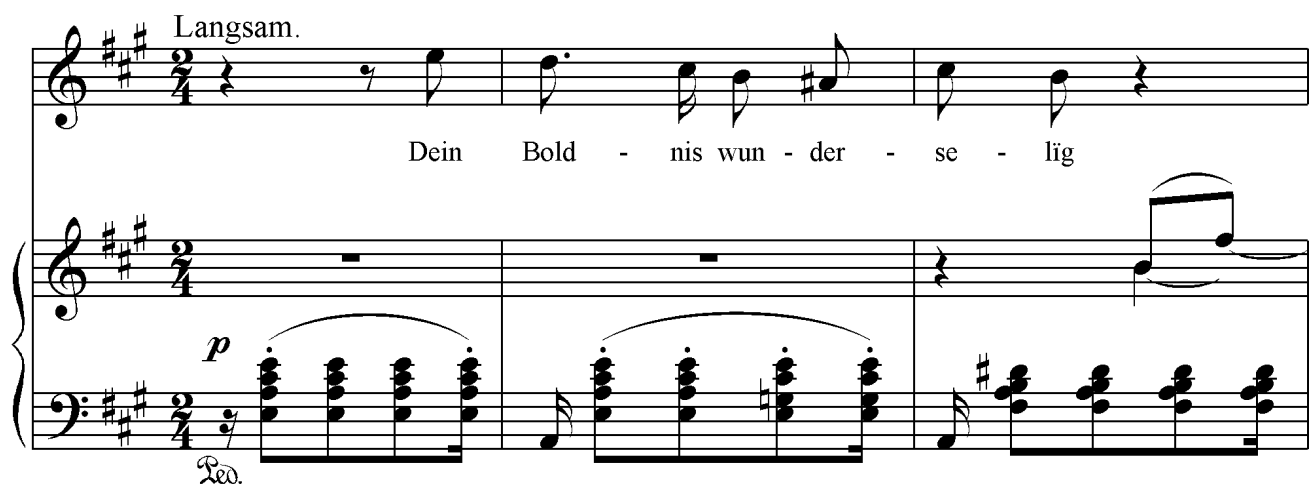

FRIEDLAENDER, M. (Ed.). Robert Schumann: Sämtliche Lieder. Leipzig: C. F. Peters, ca. 1900, p. 60.

Na música germânica, os acentos tônicos no primeiro tempo do compasso, como acontece nos exemplos abaixo, são a regra:

EXEMPLO 112: F. SCHUBERT. Der König von Thule, c. 1-8

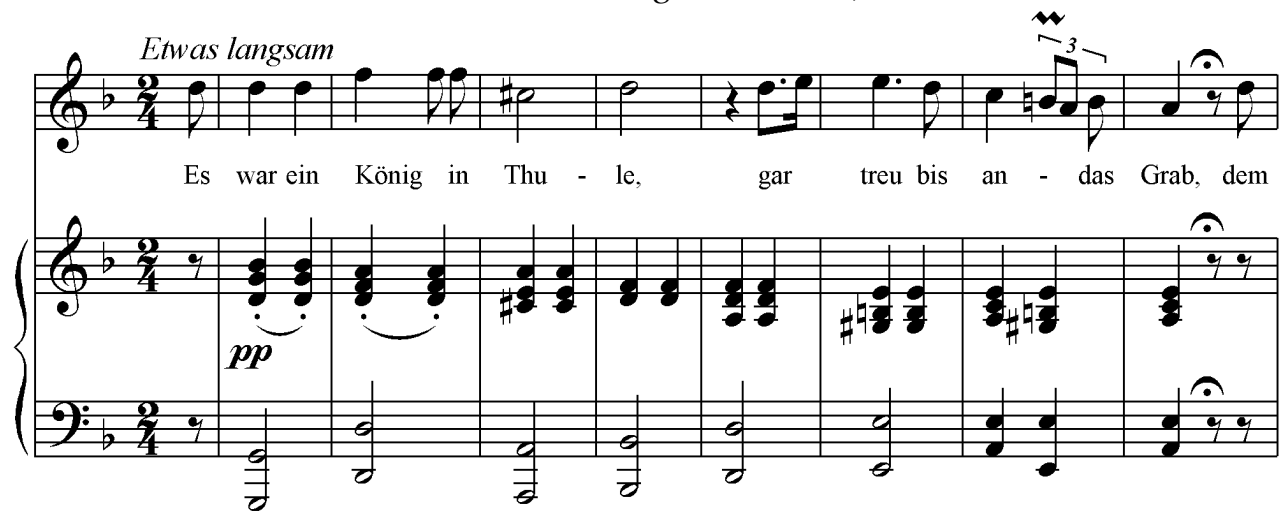

FISCHER-DIESKAU/BUDDE. (Ed.). Schubert: Lieder, vol. II. Frankfurt: C. F. Peters, ca. 1986, p. 39.

EXEMPLO 113: R. SCHUMANN. Jemand, Op. $25 n^{\circ}$ 4, c. 1-6

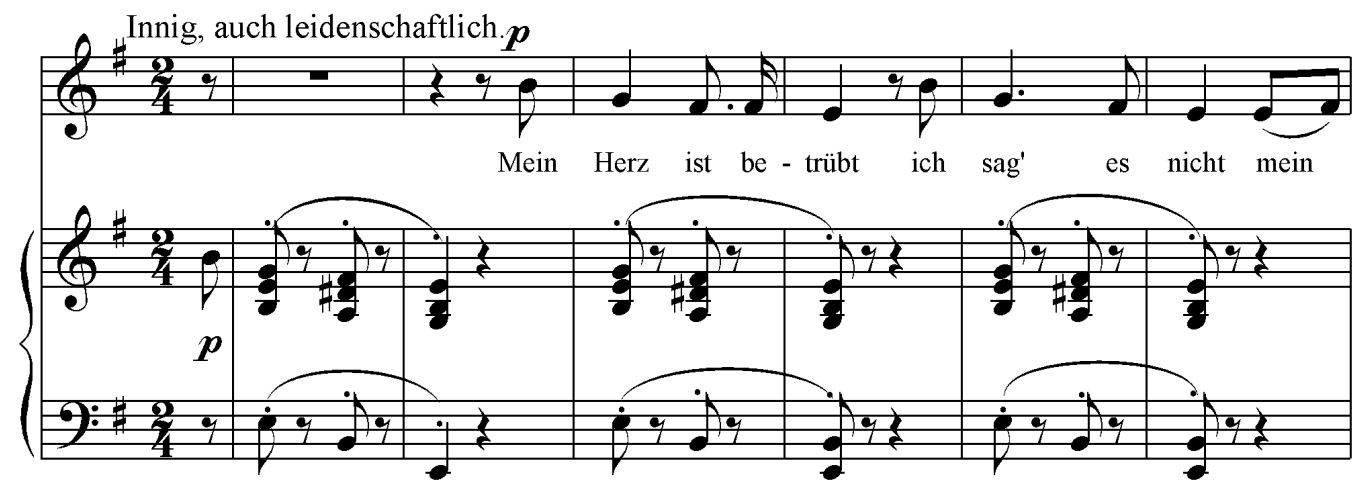

FRIEDLAENDER, M. (Ed.). Robert Schumann: Sämtliche Lieder. Leipzig: C. F. Peters, ca. 1900, p. 12. 
Essas peculiaridades rítmicas e também as melódicas de cada nação se devem obviamente à natureza rítmico-melódica dos diferentes idiomas, e é a sensibilidade de Nepomuceno para as características rítmico-melódicas do português falado no Brasil, talvez associada à tendência para os ritmos sincopados da música popular, que faz com que seu cancioneiro se constitua em um dos principais fundamentos que permitiu o florescimento da canção brasileira ao longo do século XX. 
Após 1904, seguem-se três anos sem canções, e a partir daí a produção de Nepomuceno vai se tornando esparsa. Além disso, nenhuma das canções publicadas a partir de 1907 tem número de opus, nem mesmo as que evidentemente formam pares: duas de 1908 sobre poemas de Tagore, duas de 1913 sobre textos de Olavo Bilac, e as duas ambientações de Hermes Fontes, compostas em 1915. Nepomuceno terminou em 1905 a orquestração de sua ópera $\mathrm{Abul}$, talvez a obra mais ambiciosa de toda sua produção, que ele começara a compor em 1899. Por outro lado, nos 26 concertos da Praia Vermelha (ver VERMES, 1996, p. 55) que organizou e em que atuou como regente principal por ocasião das comemorações do centenário da abertura dos portos, em 1908, destaca-se a música de Wagner e as primeiras audições de compositores russos e franceses. Destas, a obra mais importante que Nepomuceno fez ouvir no Brasil pela primeira vez talvez seja o Prélude à l'aprés-midi d'un faune, de Claude Debussy.

Temos apenas uma canção em 1907, Canto nupcial, sobre versículos bíblicos extraídos do Livro de Ruth. A canção é uma hábil e bem sucedida mistura de cântico popular e coral luterano, recurso de ambientação de que Nepomuceno, lembramos, lançou mão em sua primeira canção, Ave Maria. A comparação entre as duas canções revela o longo caminho percorrido por nosso compositor em 20 anos (Ave Maria é de 1887). São notáveis a fluência do contraponto e da harmonia em Cântico nupcial; também a articulação entre os períodos é aqui mais fluente e natural, o que dilui a forma do coral, que em Ave Maria fora usada como verdadeira fôrma: 
EXEMPLO 114: A. NePOMUCENO. Canto nupcial, c. 5-13

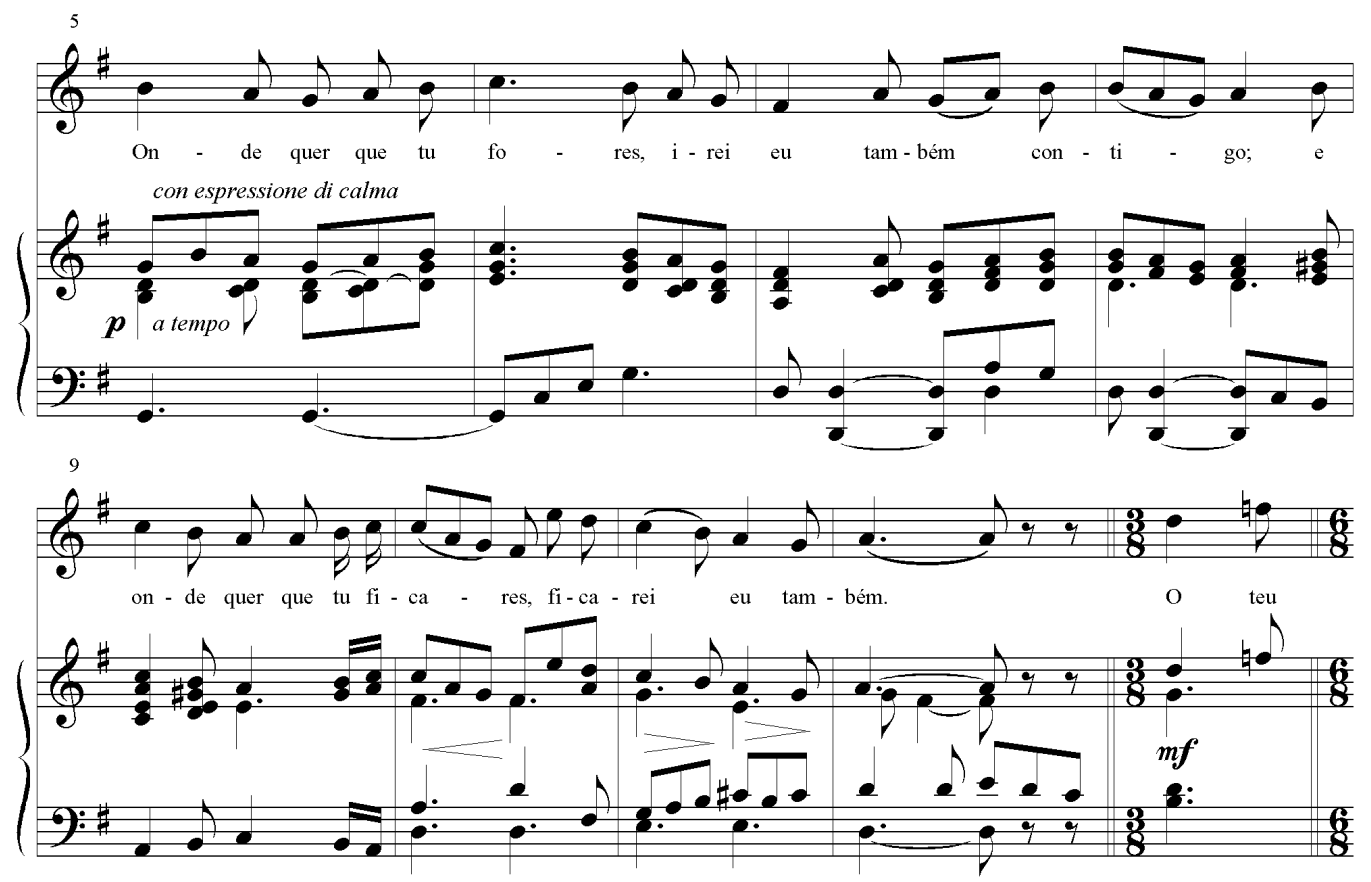

PIGNATARI, Dante (Ed.). Canções para voz e piano. São Paulo: EDUSP, 2004, p. 221.

Por outro lado, as duas melodias são aparentadas, tendo em comum os cânticos religiosos populares derivados do canto gregoriano praticado nas igrejas coloniais, que Nepomuceno certamente ouviu com frequência durante a infância e a juventude passadas no Nordeste natal. E ao menos um procedimento do vocabulário musical utilizado naquela primeira canção reaparece aqui: em Ave Maria, no compasso 51, Nepomuceno utiliza a segunda menor sob a sílaba do da palavra pecadores (ver p. 25). Em Canto nupcial, no compasso 34, temos uma sétima maior, inversão da segunda menor, para enfatizar a dor contida na primeira sílaba da palavra morte:

EXEMPLo 115: A. NePOMUCENO. Canto nupcial, c. 33-36

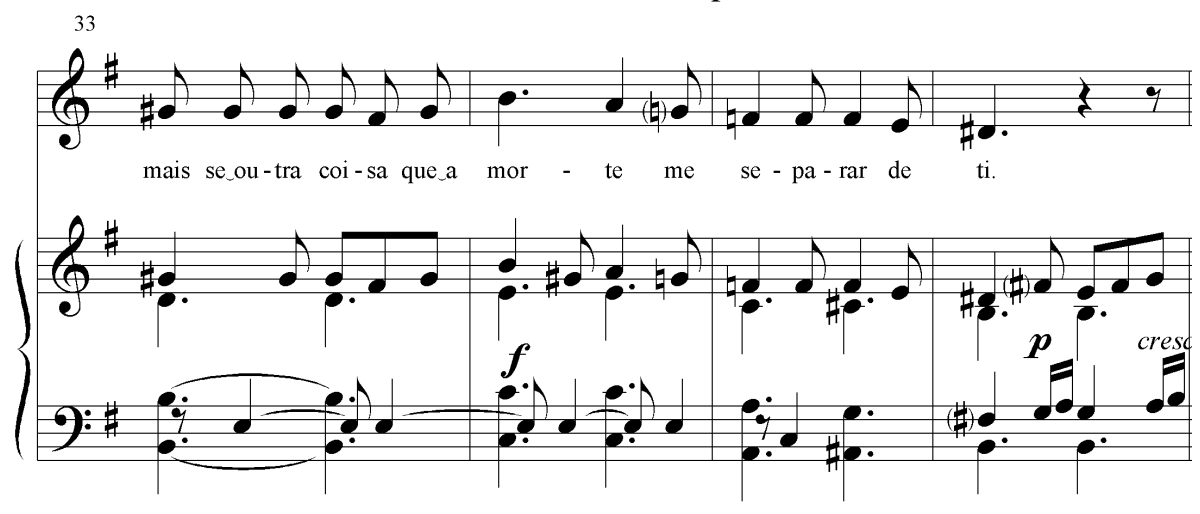

PIGNATARI, Dante (Ed.). Canções para voz e piano. São Paulo: EDUSP, 2004, p. 222. 
No ano seguinte, 1908, temos duas canções sobre poemas de Rabindranath Tagore em versão em português de Plácido Barbosa. Nelas Nepomuceno retorna súbita e definitivamente para a modernidade. A linguagem harmônica é essencialmente a vertente francesa do cromatismo pós-wagneriano, mais francesa em Candura, mais radicalmente cromática, dissonante e germânica em Flores:

EXEMPLO 116: A. NePOMUCENO. Candura, c. 1-6

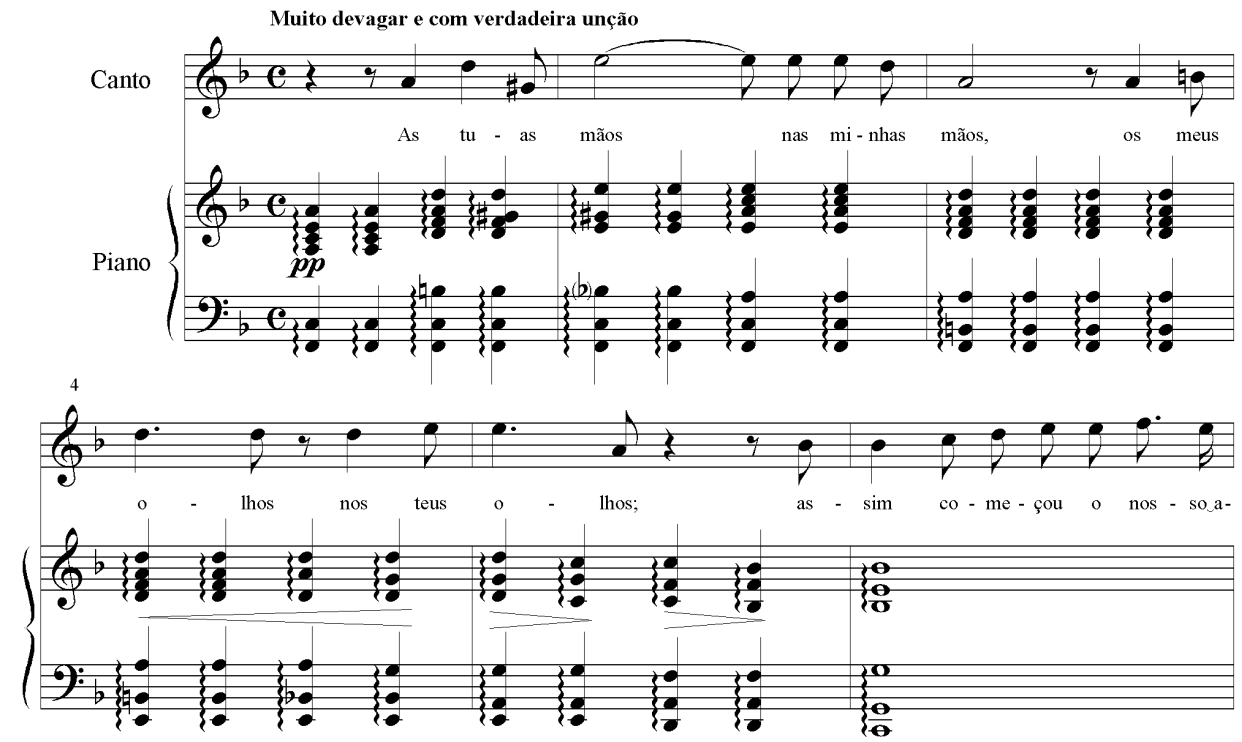

PIGNATARI, Dante (Ed.). Canções para voz e piano. São Paulo: EDUSP, 2004, p. 224.

EXEMPLO 117: A. NEPOMUCENO. Flores, c. 1-8
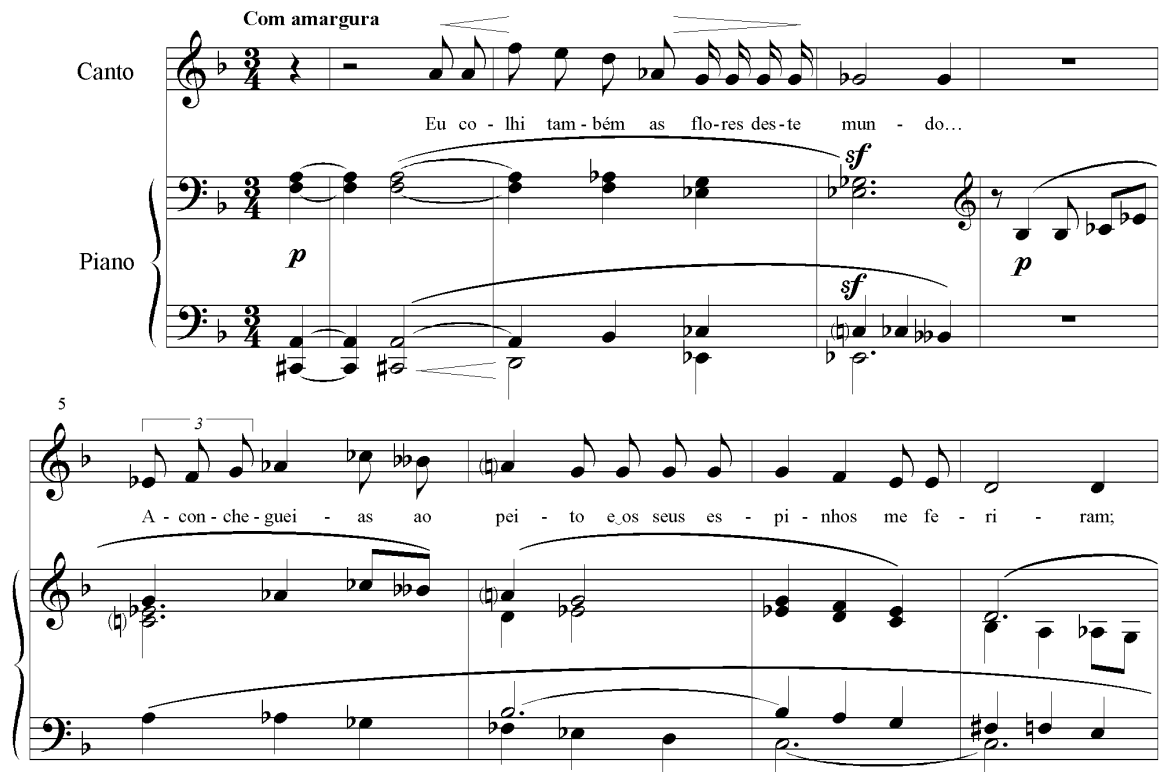

PIGNATARI, Dante (Ed.). Canções para voz e piano. São Paulo: EDUSP, 2004, p. 227. 
No caso dessas duas ambientações de Tagore, o modelo tanto da harmonia como para o recitativo da parte vocal parece ser a revolucionária ópera de Debussy, Pelléas et Mélisande. A parte vocal foi publicada em 1902, uma versão revista em 1907, e a partitura orquestral saiu em 1904. Não sabemos se Nepomuceno já conhecia a ópera de Debussy em 1908, mas quando visitou o compositor francês em 1910, recebeu deste uma cópia autografada da partitura de Pelléas (CORRÊA, 1996, p. 12).

Só podemos especular quanto ao porquê dessa guinada, mas o contraste entre a ousada modernidade das ambientações de Maeterlinck, de 1894, e o relativo conservadorismo das primeiras canções em português, também de 1894, nos faz pensar que Nepomuceno deve de alguma maneira ter constatado a impossibilidade de simultaneamente criar uma música brasileira e inscrever o país na contemporaneidade musical européia. Com suas primeiras ambientações de poetas brasileiros, ele estaria tratando de conquistar o favor do público, já que para criar uma música brasileira era necessário primeiro garantir uma posição de força no meio político-musical da Capital Federal. Em 1908, Nepomuceno provavelmente sentia-se muito mais seguro de si; ele tinha voltado a assumir em 1906 a direção do INM, cargo que já tinha ocupado brevemente em 1902-3, e ao qual renunciara, desgostoso com as irregularidades administrativas e a pressão política (ver VERMES, 1996, p. 47-48). Dirigindo a principal instituição musical do país, tendo terminado a composição de uma ópera com libreto em português, e com o sucesso dos concertos da Praia Vermelha mencionados acima, a reputação de Nepomuceno estava assegurada, e ele podia agora permitir-se as ousadias que constatamos nas ambientações de Tagore e nas que a elas se seguem.

Nossa velhice, sobre poema de Emílio de Menezes, é a única canção composta em 1909. Após recuperar a linguagem contemporânea com as ambientações de Tagore, Nepomuceno agora a submete ao processo de abrasileiramento via língua portuguesa. Nada nas canções do ano anterior permite vislumbrar o estilo híbrido do compositor. Flores, especialmente, é radicalmente pós-wagneriana, com a tonalidade distorcida pelo baixo cromático logo no primeiro acorde e resoluções harmônicas sempre postergadas por dissonâncias prolongadas. Nossa velhice, sem abandonar essa harmonia dissonante e moderna, permite o retorno de alguns gestos que encontramos em canções anteriores. Um exemplo são os acordes sincopados no acompanhamento da seção central da canção (c. 27 37), onde a tensão dissonante alcança um ápice sob os versos Nossas almas, se me esforço por 
vê-las, a vista alcança a minha como remorso, para em seguida distender-se e retornar ao ré bemol maior original em a tua como esperança:

EXEMPLO 118: A. NEPOMUCENO. Nossa velhice, c. 27-38
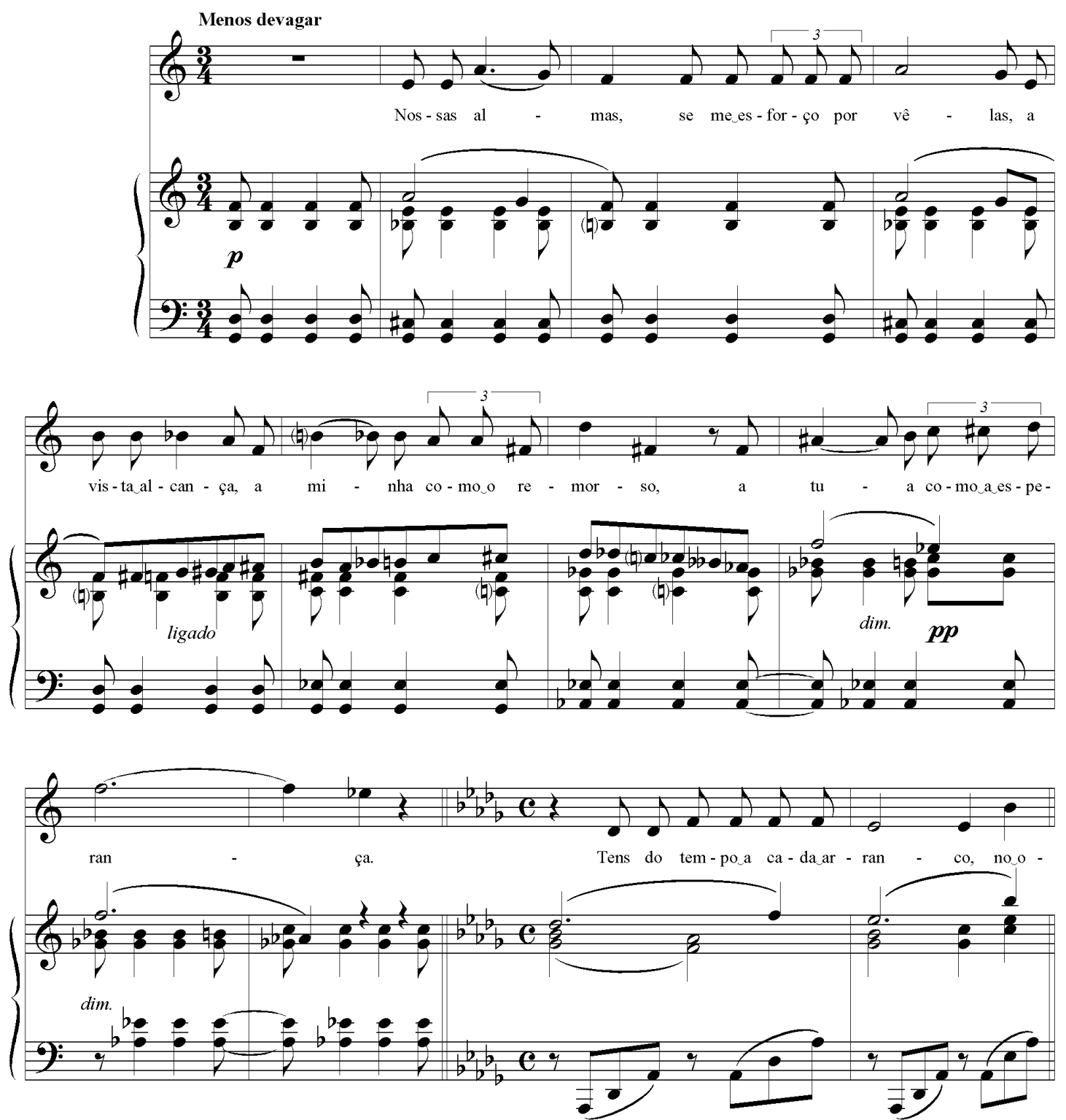

PIGNATARI, Dante (Ed.). Canções para voz e piano. São Paulo: EDUSP, 2004, p. 230-231.

Temos duas canções de 1911. Com Aime-moi, sobre poema de Emilie Arnal, Nepomuceno retorna ao idioma francês pela primeira vez desde 1895, ano das ambientações de Piazza feitas em Paris. Em comparação com as anteriores, a canção é convencional, e seu parentesco com Drömd lycka, de 1893, é bastante evidente: 
EXEMPLO 119: A. NePOMUCENO. Aime-moi, c. 1-8
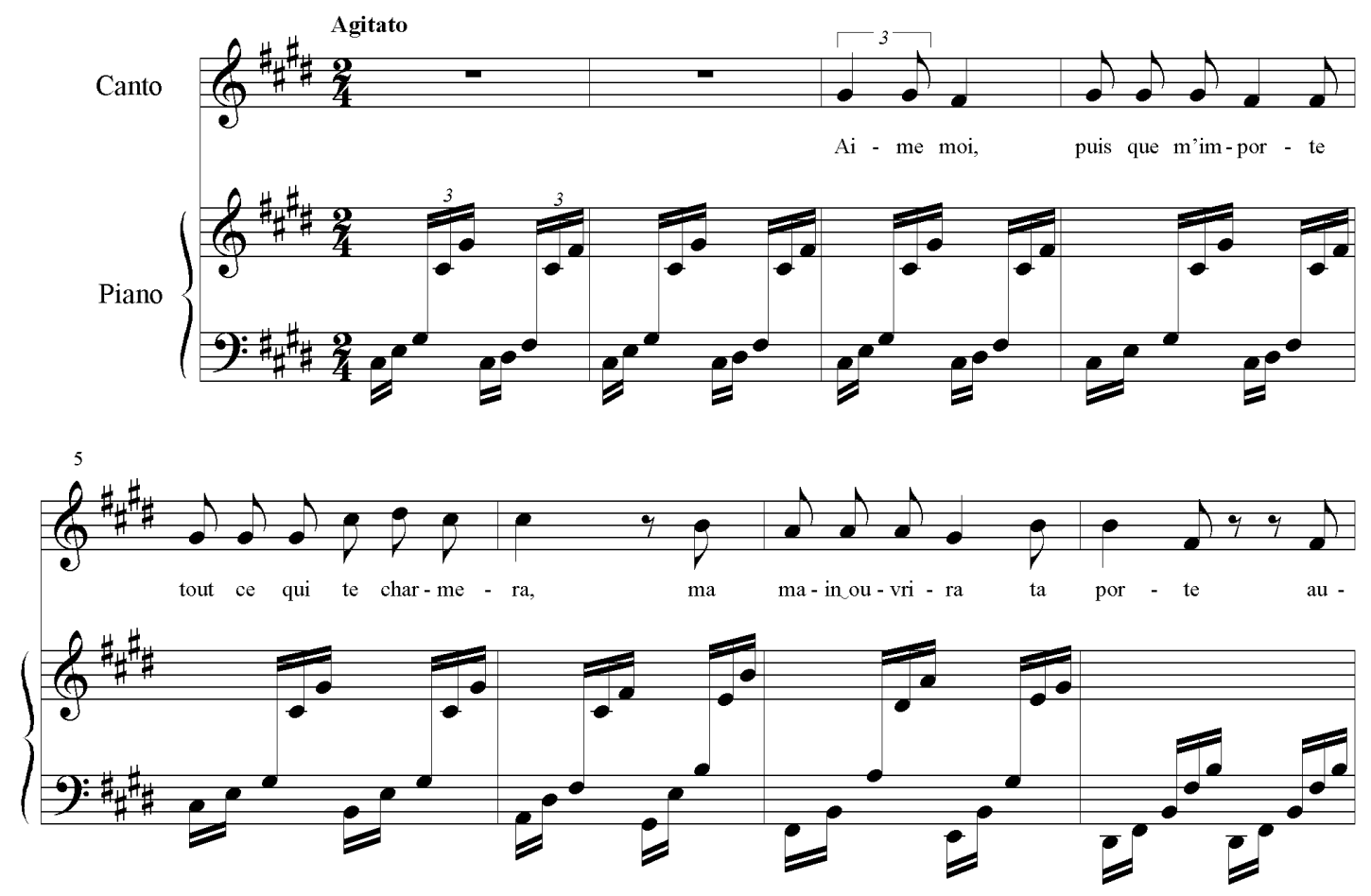

PIGNATARI, Dante (Ed.). Canções para voz e piano. São Paulo: EDUSP, 2004, p. 233.

EXEMPLO 120: A. NEPOMUCENO. Drömd lycka, c. 1-3

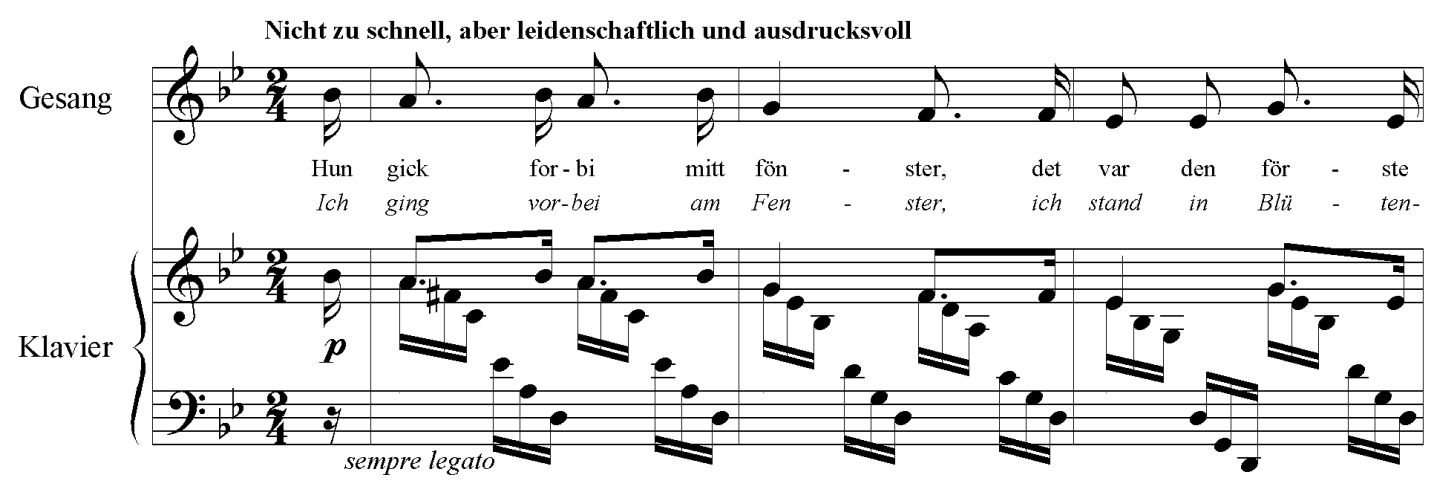

PIGNATARI, Dante (Ed.). Canções para voz e piano. São Paulo: EDUSP, 2004, p. 66.

Além disso, o fato de a peça ter permanecido em manuscrito nos faz pensar em uma composição de ocasião.

A outra peça de 1911, Razão e amor, é de outro quilate. A canção só foi publicada após a morte de Nepomuceno; uma pista para explicar por que o compositor não publicou esta pequena jóia pode estar na dedicatória, "para sua boa amiga D. Nini”, ao menos segundo a versão de Luiz Heitor para o compositor ter-se separado da esposa em 1901: 
[...] O malogro da vida conjugal de Nepomuceno tivera como origem uma outra mulher, esposa do crítico musical e fiel amigo de Nepomuceno, também seu colaborador literário, Luís de Castro. Essa aventura sentimental foi, segundo alguns, puramente platônica, nascida de uma profunda afinidade de espírito e de sensibilidade. Mas tornara-se tão patente que acabou provocando a dissolução do lar do compositor, apesar dos filhos, aos quais ele muito queria. (em VERMES, 1996, p. 45).

A mulher de Luís de Castro era justamente a D. Nini da dedicatória de Razão e amor. A canção lembra Trovas II, tanto no espírito jocoso como pelo ar espanhol, lá especialmente no ritmo, aqui no acompanhamento chitarrevole e, principalmente, em gestos melódicos como este ornamento:

EXEMPLO 121: A. NEPOMUCENO. Razão e amor, c. 8 e 9

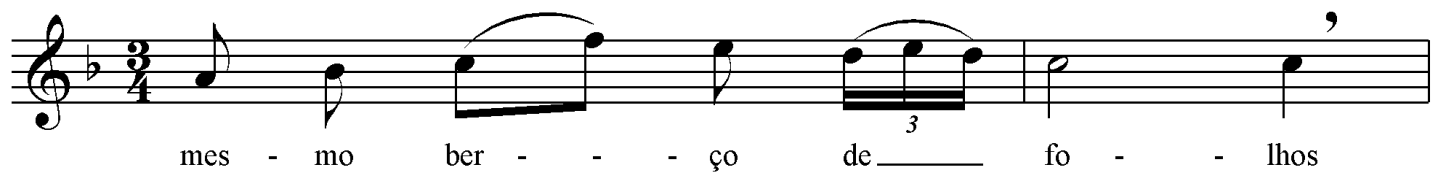

PIGNATARI, Dante (Ed.). Canções para voz e piano. São Paulo: EDUSP, 2004, p. 236.

Em 1912 temos somente uma canção, Ocaso, poema de Thomaz Lopes. Chamamos a atenção para dois aspectos da canção. Um deles é o reaparecimento do grandioso tema da Polonaise-Fantaisie de Chopin, que reconhecemos em A grinalda, aqui inclusive com o mesmo ritmo pontuado: 
EXEMPLO 122: A. NePOMUCENO. Ocaso, c. 13-18

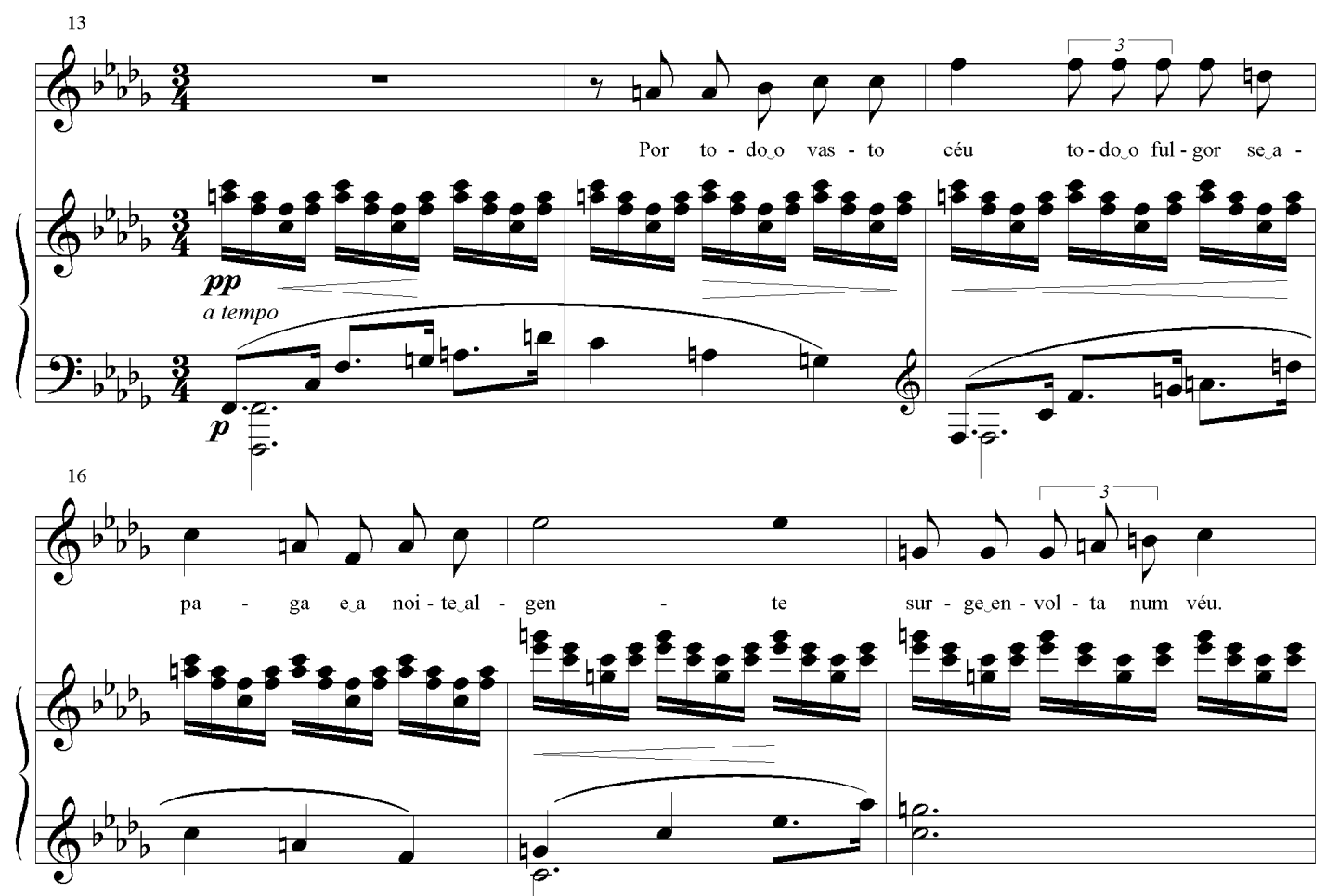

PIGNATARI, Dante (Ed.). Canções para voz e piano. São Paulo: EDUSP, 2004, p. 238.

EXEMPLO 123: F. CHOPIN. Polonaise-Fantaisie, Op. 61, c. 254-255

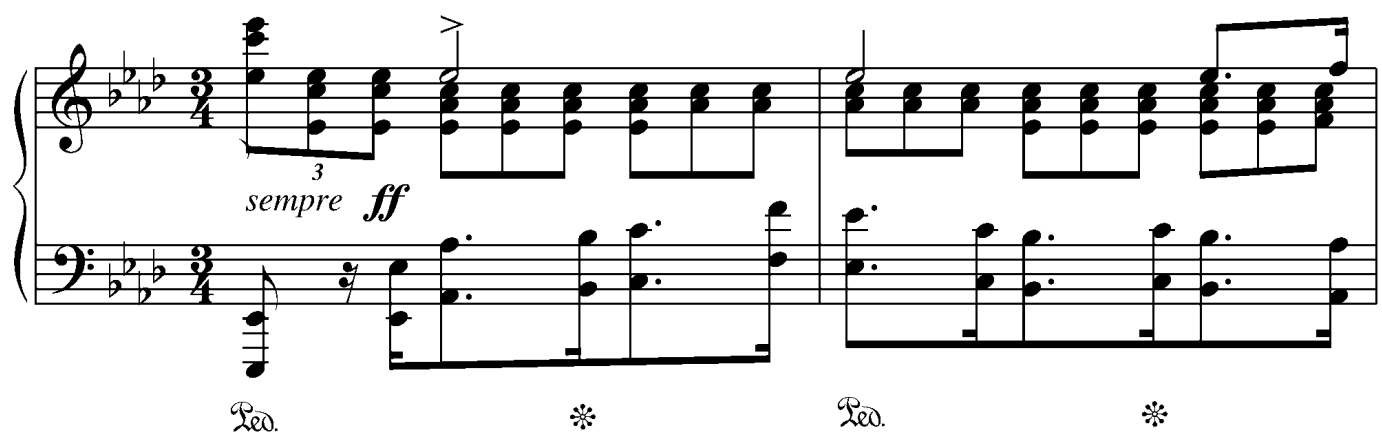

ZIMMERMANN, Ewald (Ed.). Fredéric Chopin: Polonaisen. Munique: G. Henle, 1972, p. 90.

O outro aspecto que destacamos refere-se ao vocabulário do estilo pessoal de Nepomuceno. Os compassos de Ocaso reproduzidos acima ilustram a noite estrelada. Listamos abaixo alguns momentos de outras canções e outra instância em Ocaso em que a música se refere ao mesmo tema. Destaco a semelhança das figurações e principalmente, harmônica. Ainda que de forma passageira, a tonalidade de sol maior está presente em todos os exemplos abaixo: 
EXEMPLO 124: A. NEPOMUCENO. Mater dolorosa, c. 20-24

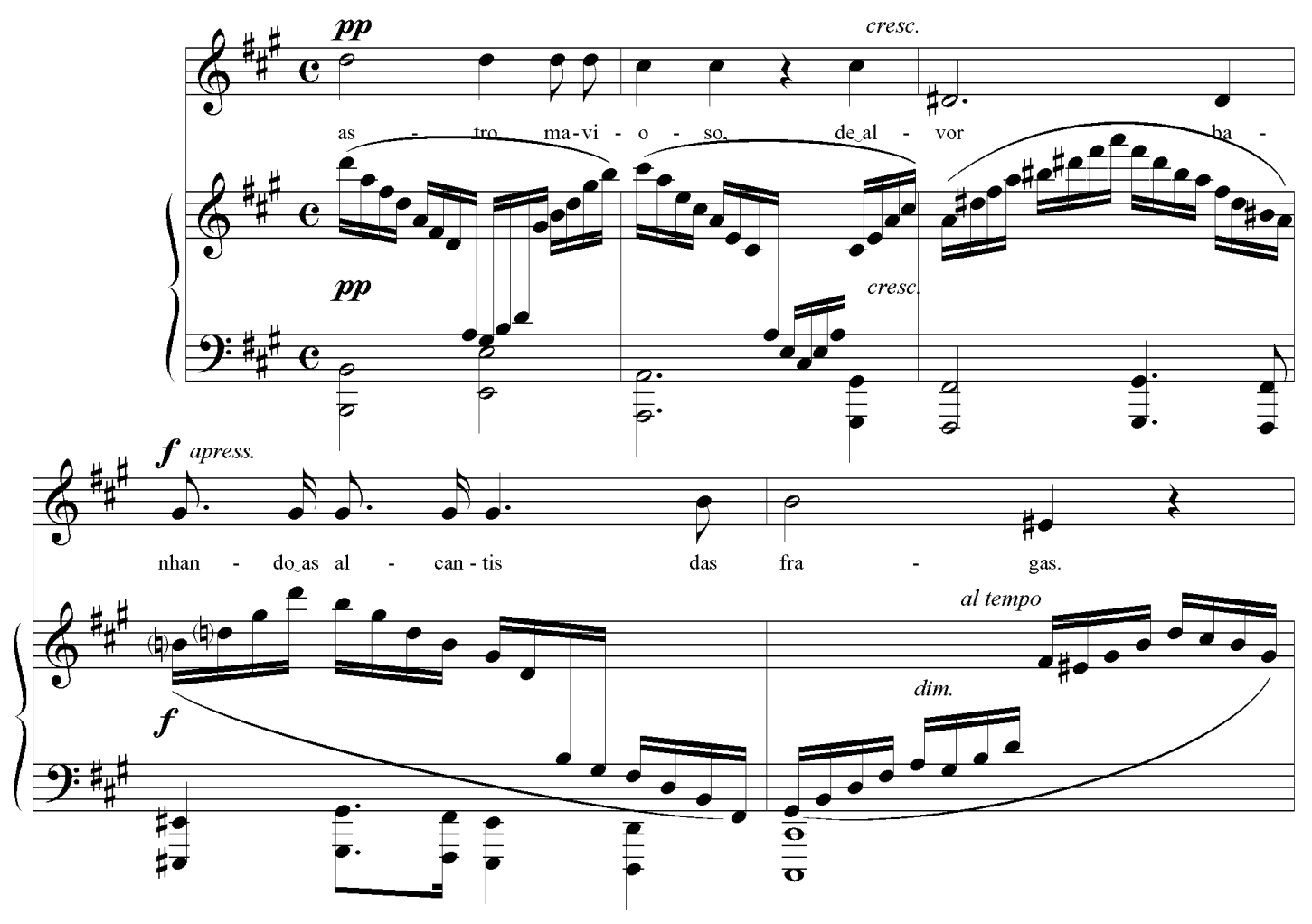

PIGNATARI, Dante (Ed.). Canções para voz e piano. São Paulo: EDUSP, 2004, p. 110-111.

EXEMPLO 125: A. NEPOMUCENO. Morta, c. 26-28

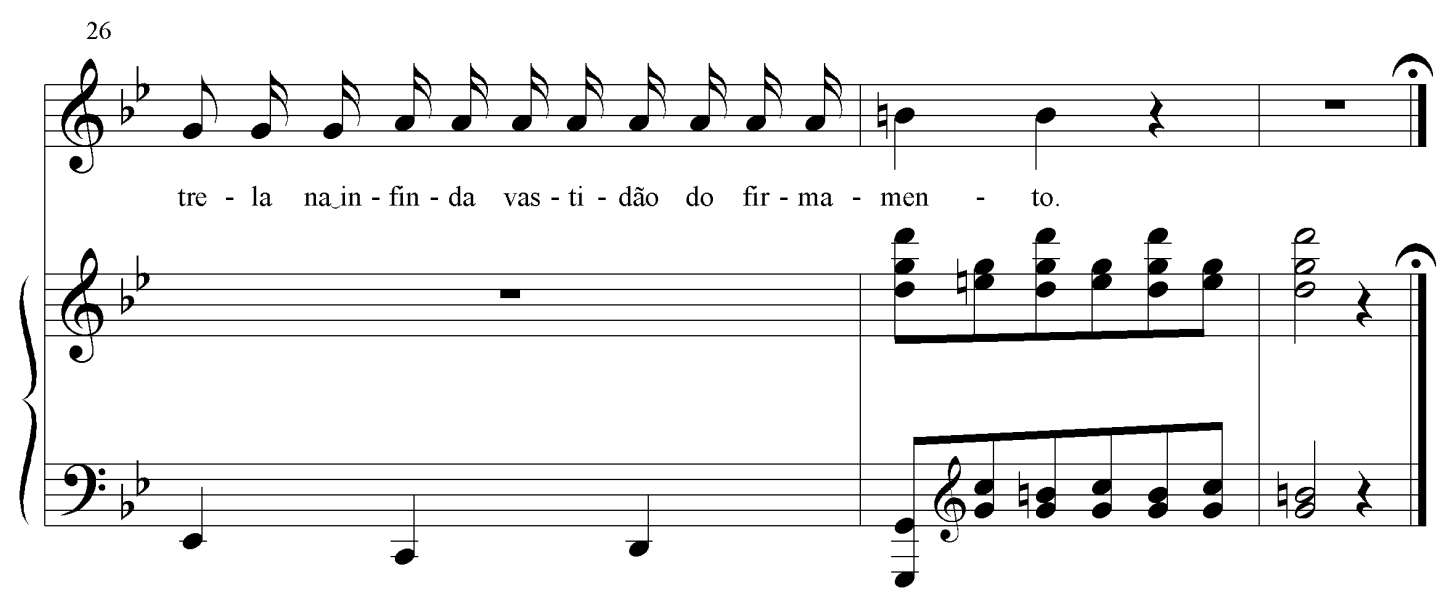

PIGNATARI, Dante (Ed.). Canções para voz e piano. São Paulo: EDUSP, 2004, p. 26-28. 
EXEMPLO 126: A. NePOMUCENO. Canção, c. 29-36
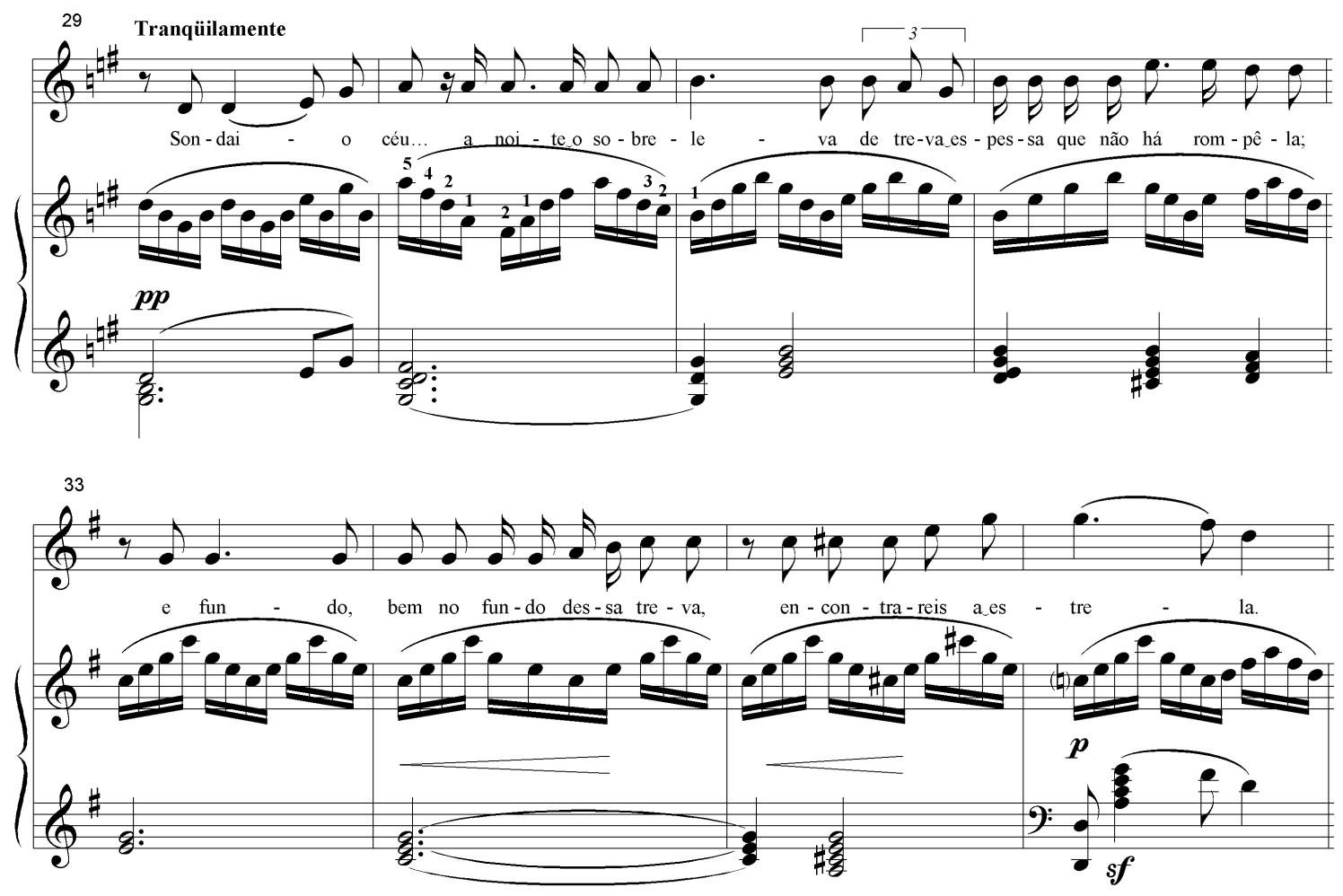

PIGNATARI, Dante (Ed.). Canções para voz e piano. São Paulo: EDUSP, 2004, p. 195-196.

EXEMPLO 127: A. NEPOMUCENO. Ocaso, c. 28-30

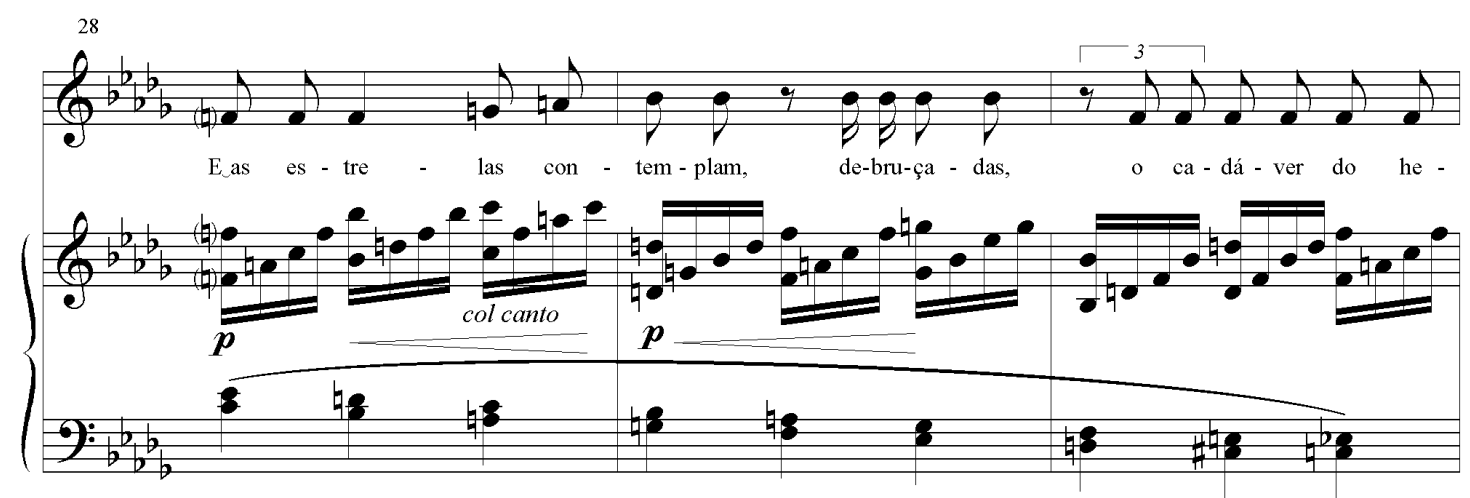

PIGNATARI, Dante (Ed.). Canções para voz e piano. São Paulo: EDUSP, 2004, p. 239.

No ano seguinte, 1913, temos duas ambientações de Olavo Bilac, Numa concha e Olha-me! Ambas são exemplos da técnica de "abrasileiramento" utilizada por Nepomuceno. No ritmo, o acompanhamento em contratempo, que aqui tem pouco a ver com a síncopa da música popular, e sim com uma certa "tensão brasileira" do tempo; só assim se explica a presença tão frequente desse tipo de acompanhamento no cancioneiro. Na primeira canção do par, Numa concha, temos o tipo clássico de acompanhamento de acordes em contratempo com o baixo: 
EXEMPLO 128: A. NEPOMUCENO. Numa concha, c. 1-3

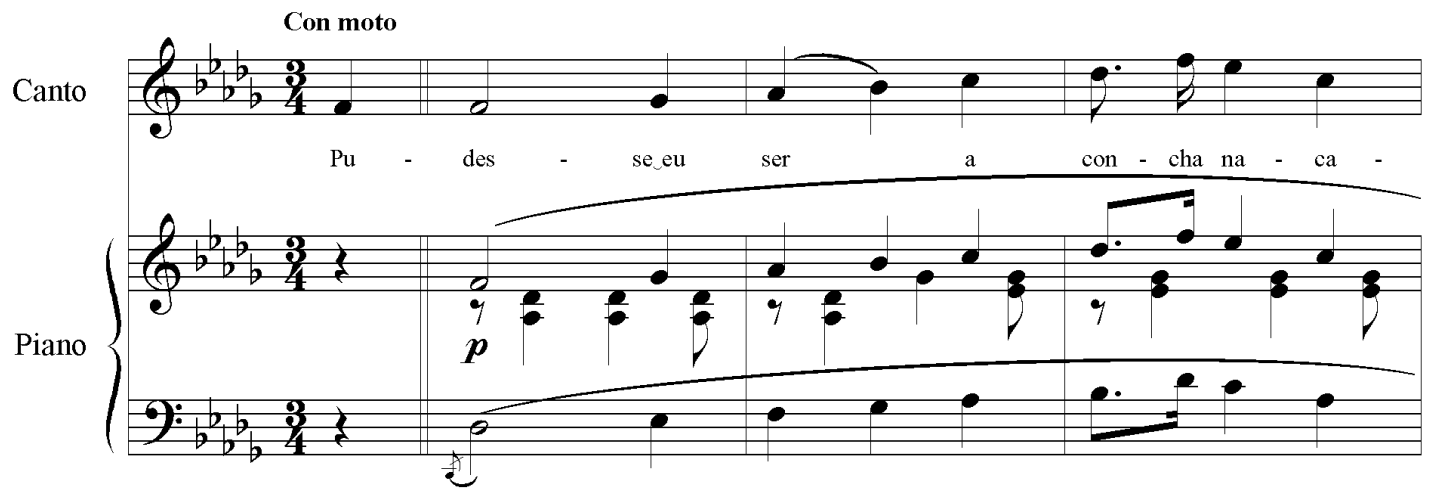

PIGNATARI, Dante (Ed.). Canções para voz e piano. São Paulo: EDUSP, 2004, p. 240.

Em Olha-me! a presença desse contratempo é mais complexa, devido ao compasso 9/8 e ao contraponto mais elaborado (em Numa concha, a linha melódica do piano quase sempre acompanha a linha vocal em sextas paralelas ou simplesmente a dobra). No início aparece no baixo, mas no compasso 4 passa para a parte superior do piano:

EXEMPLO 129: A. NEPOMUCENO. Olha-me, c. 1-5

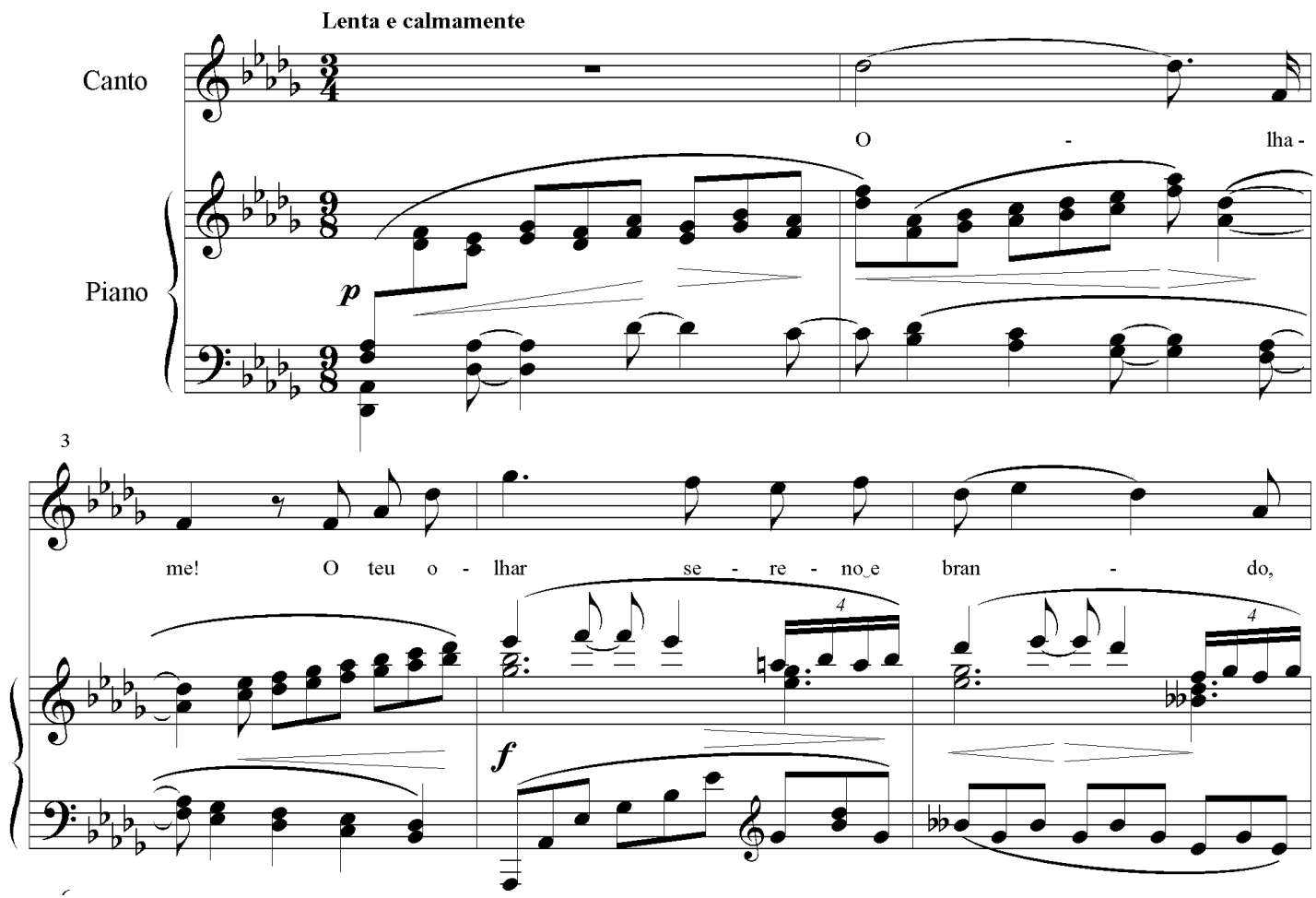

PIGNATARI, Dante (Ed.). Canções para voz e piano. São Paulo: EDUSP, 2004, p. 243. 
Em 1915, novamente duas canções, agora com poemas de Hermes Fontes. Canção da ausência e Luz e névoa são as mais vanguardistas das canções de Nepomuceno. A linguagem harmônica é derivada diretamente de Debussy em sua vertente mais radicalmente moderna. $\mathrm{E}$ novamente o elemento rítmico utilizado para ambientar os versos do poeta simbolista é, em Canção da ausência, o contratempo sincopado:

EXEMPLO 130: A. NePOMUCENO. Canção da ausência, c. 1-4

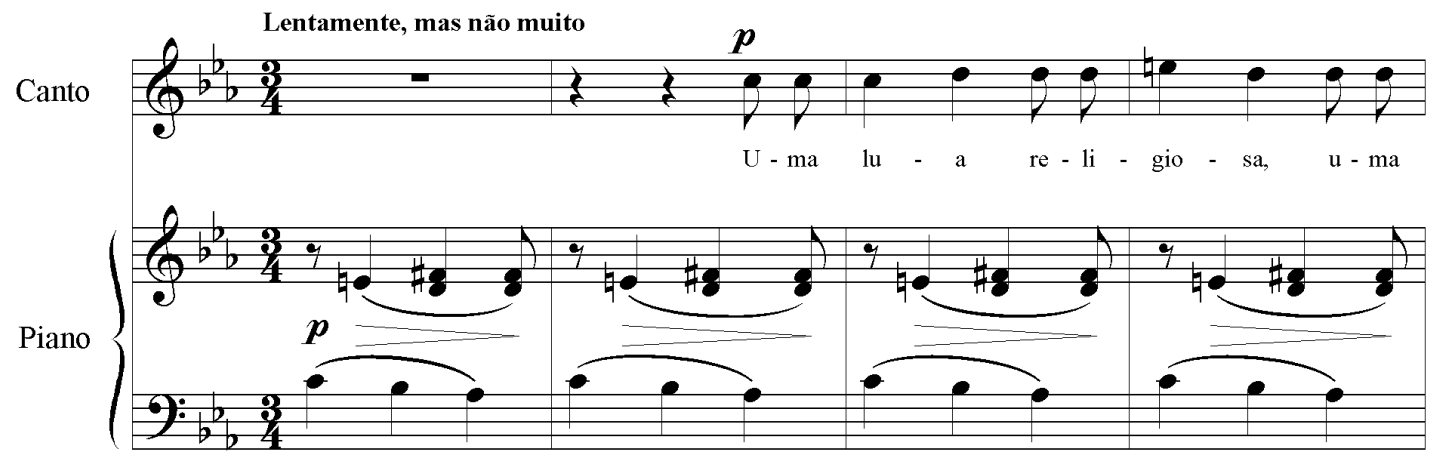

PIGNATARI, Dante (Ed.). Canções para voz e piano. São Paulo: EDUSP, 2004, p. 247.

Já o ritmo do acompanhamento de Luz e névoa poderia ser derivado da música popular se o andamento fosse mais rápido, mas aqui é irreconhecível como tal devido também à harmonia cromática e dissonante:

EXEMPLO 131: A. NePOMUCENO. Luz e névoa, c. 1-3

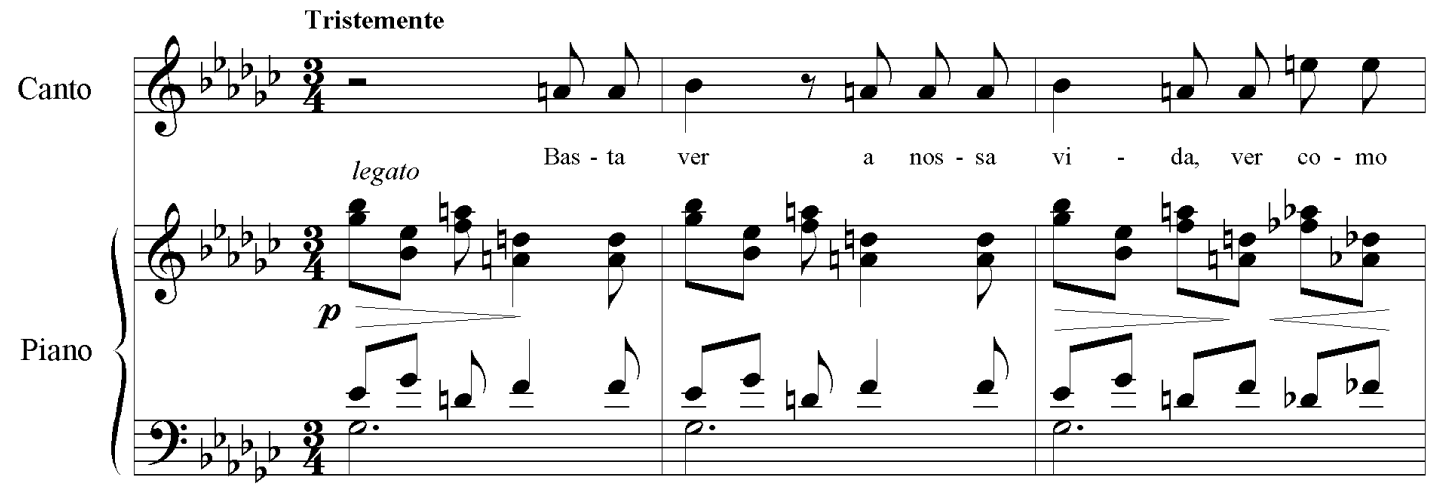

PIGNATARI, Dante (Ed.). Canções para voz e piano. São Paulo: EDUSP, 2004, p. 251.

As linhas vocais de ambas as canções são recitativos que, tomados isoladamente, sem o acompanhamento, são de uma ousadia inusitada para a época. Há trechos em que é 
impossível descobrir o contexto harmônico só pela melodia, e a ambiguidade harmônica é constante, às vezes beirando o atonalismo ${ }^{27}$ :

EXEMPLO 132: A. NEPOMUCENO. Canção da ausência, c. 16-27
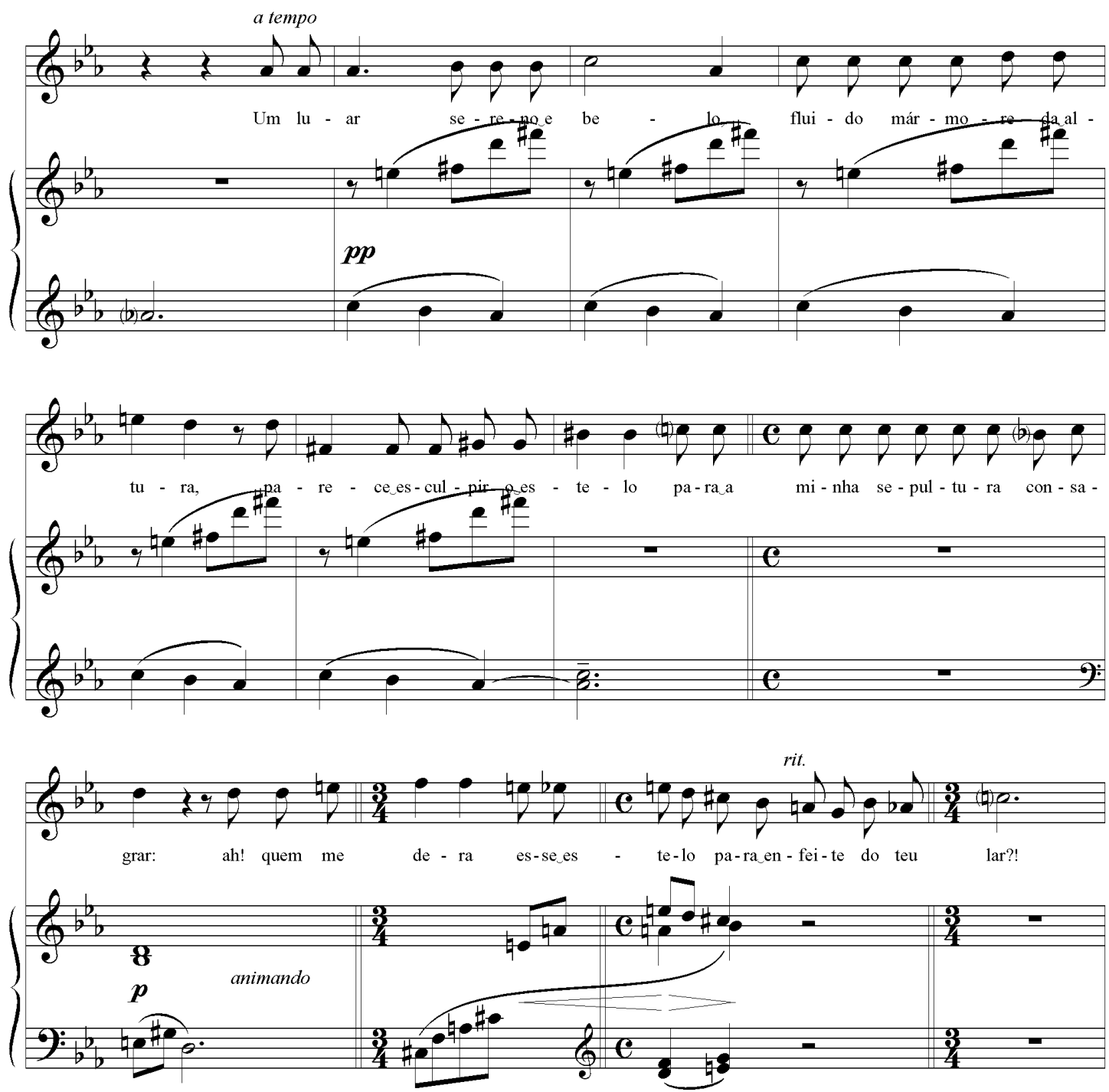

PIGNATARI, Dante (Ed.). Canções para voz e piano. São Paulo: EDUSP, 2004, p. 247-248.

\footnotetext{
${ }^{27}$ Não sabemos se Nepomuceno conhecia as obras do período atonal de Schoenberg, mas pelos indícios de que dispomos, isso é bastante provável. Em 1916 ele iniciou a tradução do Tratado de Harmonia de Schoenberg, e cogitou adotar a obra no INM (ver VERMES, 1996, p. 70).
} 


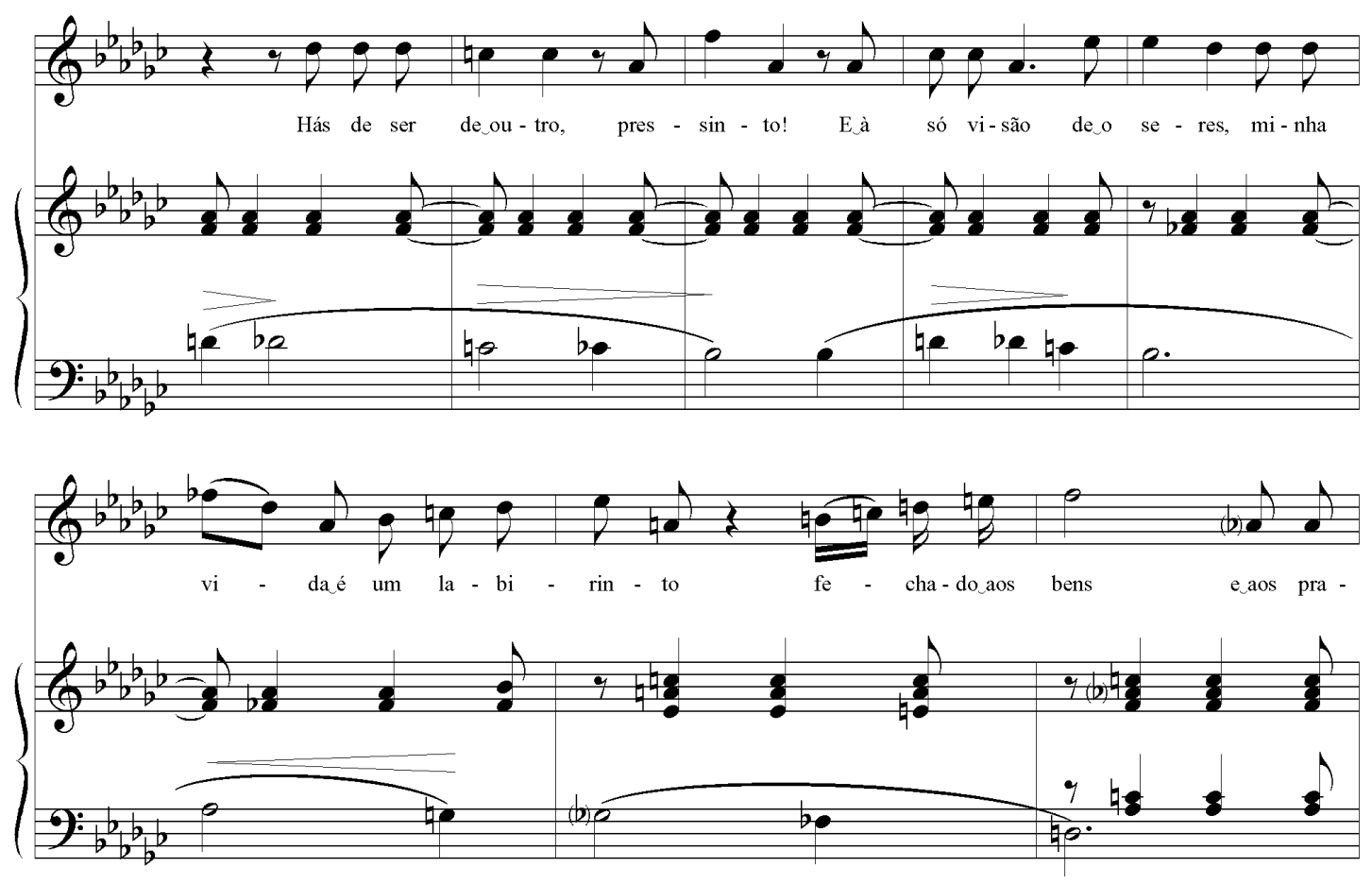

PIGNATARI, Dante (Ed.). Canções para voz e piano. São Paulo: EDUSP, 2004, p. 252-253.

A pedido de José Freitas Valle, entre 1916 e 1917 Nepomuceno compõe o ciclo Le miracle de la semence. Os textos em francês são do próprio Freitas Valle, que aqui utiliza o pseudônimo de Jacques d'Avray. Trata-se na verdade de uma cantata com acompanhamento orquestral, único caso após Epitalâmio, de 1897, de peça para voz solista concebida para ser acompanhada por uma orquestra.

E de 1917 é a penúltima canção escrita por Nepomuceno. Canção do rio é uma cantiga simples, ingênua mesmo, e visceralmente brasileira, da melodia derivada diretamente da cantiga popular ao balanço característico do compasso 6/8: 
EXEMPLO 134: A. NEPOMUCENO. Canção do rio, c. 1-8
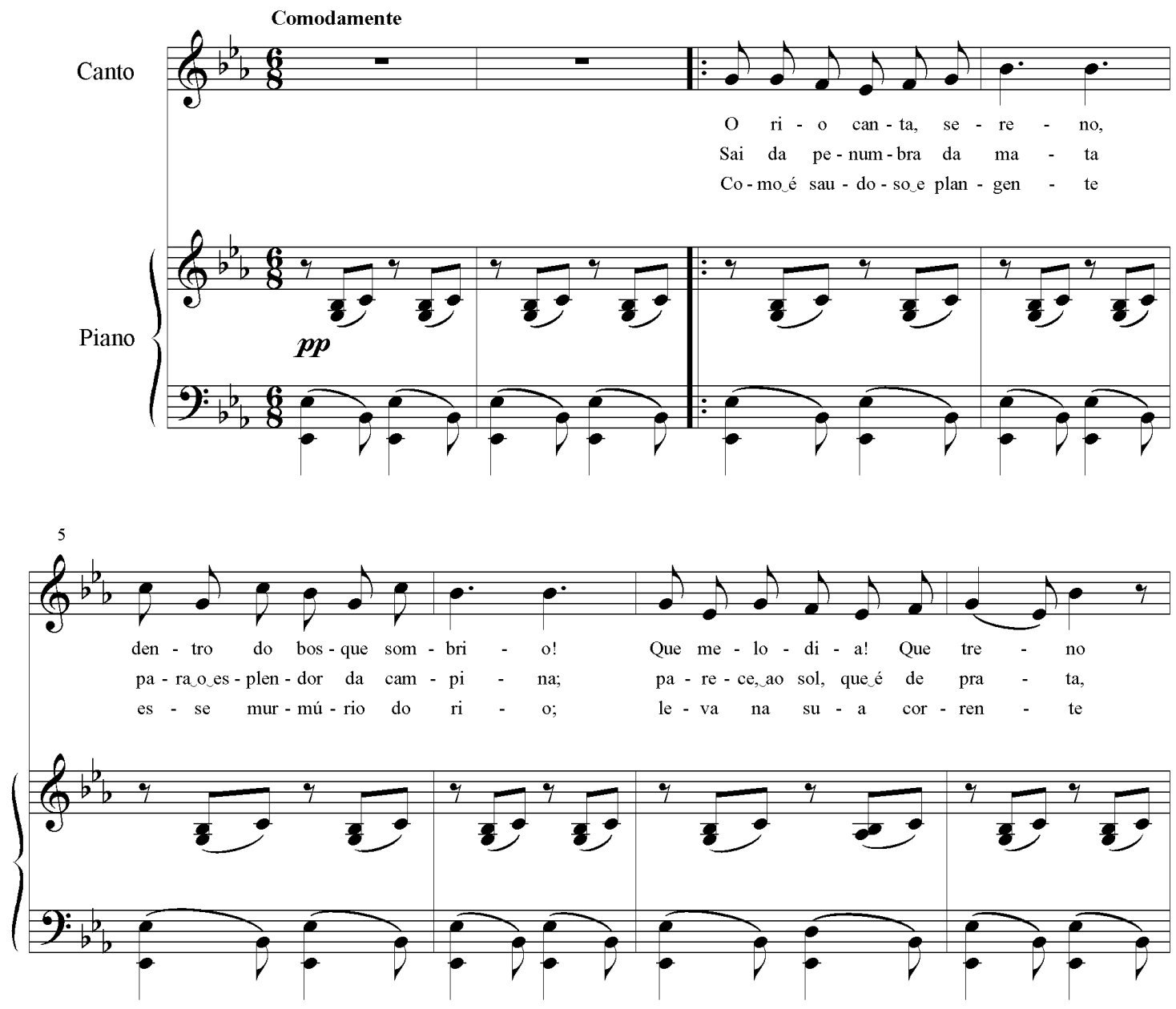

PIGNATARI, Dante (Ed.). Canções para voz e piano. São Paulo: EDUSP, 2004, p. 271.

A forma estrófica, a simplicidade da harmonia e a singeleza da linha melódica são sinais de uma reaproximação, de um retorno ao universo popular. Após as ousadias inauguradas com as ambientações de Tagore, esta ambientação dos versos de Domingos Magarinos parece uma pausa para reflexão. Somente a proximidade da morte, três anos depois, levará Nepomuceno a um último esforço, que resultará em uma canção-testamento. 
CAPÍTULO 15 - A JANGADA (1920)

Alberto Nepomuceno morreu em 16 de Outubro de 1920. Luiz Heitor relata as circunstâncias que o abalaram e precipitaram o desenlace:

\begin{abstract}
No ano seguinte (1916) um novo desgosto, e esse muito profundo, comprometendolhe irremediavelmente a saúde, já não muito firme, abateu-se sobre o compositor. A anulação arbitrária, por parte do governo, de um concurso para professor do Instituto Nacional de Música, que ele presidira, e que se realizara dentro das mais estritas normas de justiça e equidade, motivou o seu pedido de demissão, altivamente apresentado, com a recusa formal de executar as determinações ministeriais relativas a esse ato iníquo. Nepomuceno era, como grande parte dos verdadeiros artistas, de uma extrema suscetibilidade, e a injustiça que se praticava, atingindo as suas convicções e o seu caráter, bem como o desconhecimento dos muitos anos de amoroso serviço que prestara ao estabelecimento, constituiram golpe fatal, que repercutiu não somente sobre o moral, mas, como já foi dito, sobre o próprio físico do compositor, encurtando-lhe os anos de vida. Segundo depoimento de todos os que o conheceram, nunca mais ele voltou a ser o que fora antes dos acontecimentos de outubro de 1916. Embranqueceu, tinha o olhar amortecido e os seus amigos viam, aflitos, que caminhava a passos largos para a morte. (AZEVEDO, 1956, p. 172-173).
\end{abstract}

É ainda Luiz Heitor quem nos conta que sua última canção foi escrita no leito de morte e descreve a agonia do compositor:

\begin{abstract}
Sua derradeira composição, que não pôde ultimar, foi uma canção sobre versos do grande vate cearense Juvenal Galeno: A jangada. Passara a residir em casa do seu fraternal amigo Frederico Nascimento, à Rua Teresina, em Santa Teresa. E lá expirou a 16 de outubro de 1920. Otávio Bevilacqua, testemunha ocular do seu passamento, narra que ele cantava, na hora da morte, tal como fizera José Maurício Nunes Garcia. E a morte veio quando esses cantos, gradualmente enfraquecidos, tornaram-se um imperceptível sussurro substituído afinal pelos últimos estertores da agonia. (AZEVEDO, 1956, p.173-174).
\end{abstract}

A jangada é o testamento de Alberto Nepomuceno, um modelo de síntese de elementos nacionais e dos recursos da música européia moderna. Em seus últimos anos de vida, e especialmente à medida em que pressentia a aproximação da morte, o compositor se preocupava com o futuro da música brasileira. Já em 1903, por ocasião da composição do Hino do Ceará, em uma carta dirigida ao barão de Studart (que lhe encomendara a obra) "Nepomuceno explica os procedimentos melódicos utilizados na elaboração desse hino, os quais evidenciam seu conhecimento das estruturas da música folclórica brasileira." (VERMES, 1996, p. 51). Um sinal dessa preocupação é a Canção do rio, talvez a recriação mais literal do universo popular em todo o cancioneiro. Um outro sinal comprobatório, este 
bem mais decisivo, está na entrevista concedida no Rio de Janeiro ao periódico A Época em

27 de dezembro de 1917, que reproduzimos na íntegra:

- Executava há pouco a rapsódia de um tema sertanejo, não é verdade? Poderia o ilustre maestro nos dizer, a propósito, se a música brasileira tem uma nota verdadeiramente independente e característica?

- Em geral as notas características da música popular brasileira são as indicativas de suas origens étnicas - indígena, africana, e peninsular - tal como na poesia popular foi verificado por nossos folcloristas, como Sylvio Romero, Mello Moraes Filho e outros. É de notar que no elemento peninsular são fatores de importância o mouro e o cigano. Infelizmente a parte musical dos estudos do folclore brasileiro ainda não foi estudada, provavelmente por ser a técnica musical uma disciplina que escapa ao conhecimento dos investigadores do assunto.

Nunca me dediquei a esses estudos, mas possuo, como diletante, uma coleção de uns oitenta cantos populares, e danças, e procuro sempre aumentá-la. Acham-se quase todos estudados e classificados, e, nesse trabalho, verifiquei uma modalidade que não é regional, pois que se encontra em cantos recolhidos no Pará, no Ceará e no interior do Estado do Rio e que parece-me não tem ligação com nenhum dos elementos étnicos acima citados. Essa modalidade, de ordem melódica e harmônica, é produzida pelo abaixamento do sétimo grau sempre que o canto tenda para o sexto, como função do $2^{\circ}$ ou do $4^{\circ}$ graus.

Outra modalidade característica verificada em grande número de cantos é a da nota final ser o $3^{\circ}$ grau e, por vezes, o $5^{\circ}$, ou $2^{\circ}$ como função do $5^{\circ}$, o que dá lugar, na harmonização desses cantos, ao emprego das cadências finais do terceiro e sétimo modos gregorianos, respectivamente. Não é esta a única afinidade que encontrei com o canto-chão. Nos aboiados - cantos tristes que os vaqueiros entoam à frente do gado para reuni-lo - o vaqueiro, segundo as circunstâncias amplia o seu aboiar com vocalizes que lembram os do canto-chão. Os aboiados são usados em todos os estados criadores do Nordeste, e segundo estou informado, em Minas e Goiás...

Esses elementos ainda não estão incorporados ao patrimônio artístico dos nossos compositores. Será por culpa da nossa educação musical européia, refinada, que impede a aproximação do artista-flor de civilização - e da alma simples dos sertanejos, que ainda hoje - por criminosa culpa dos governos - não passam de retardatários, segundo a classificação justa de Euclides da Cunha: ou será por não ter ainda aparecido um genio musical sertanejo, imbuído de sentimentos regionalistas, que, segregando-se de toda influência estrangeira, consiga criar a música brasileira por excelência, sincera, simples, mística, violenta, tenaz e humanamente sofredora, como são a alma e o povo do sertão.

- Mas quais os autores estrangeiros que mais têm influído na formação da música brasileira?

- Na música popular não foram indivíduos que influiram na sua formação, mas sim raças. Na música já com pretensão à arte, e que muitos pensam tenha um caráter nacional, como seja a modinha, influiu exclusivamente na sua formação a escola italiana, não somente quanto à forma, mas também quanto à idéia melódica, e ao acompanhamento chitarrevole.

A nossa educação musical é feita atualmente sob a tríplice influência das escolas alemã, francesa e italiana, mas são as duas últimas que mais se fazem sentir nas nossas produções. (CORRÊA, 1996, p. 31).

Em sua última canção, Nepomuceno retorna ao conterrâneo Juvenal Galeno e a um tema cearense por excelência, a jangada. Mais ainda, uma metáfora tristemente adequada a quem se despede da vida, já que o questionamento feito pelo jangadeiro à jangada é seguir a labuta no mar ou retornar à praia para descansar. O baixo do acompanhamento pianístico é 
novamente uma variação do ritmo de habanera na mão esquerda, disfarçado pelos acordes em contratempo na mão direita. O resultado é um movimento ondulatório com balanço brasileiro, uma recriação musical do mar nordestino. Por sobre ele paira a voz, representando jangada e jangadeiro, tensionada ritmicamente pelas tercinas sobrepostas à subdivisão quaternária do acompanhamento:

EXEMPLO 135: A. NePOMUCENO. A jangada, c. 5-8

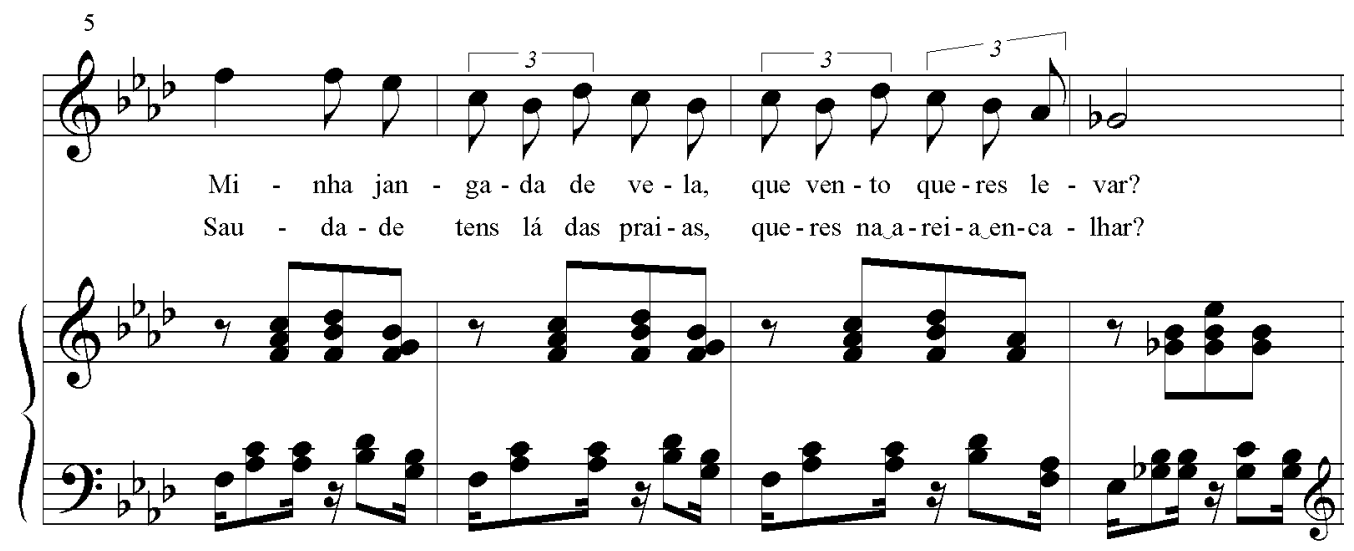

PIGNATARI, Dante (Ed.). Canções para voz e piano. São Paulo: EDUSP, 2004, p.273.

Essa imagem de melodia pairando sobre um acompanhamento aquático não é inédita na música ocidental. Abaixo, dois exemplos escolhidos a esmo:

EXEMPLO 136: F. SCHUBERT. Ave Maria, c. 3-4

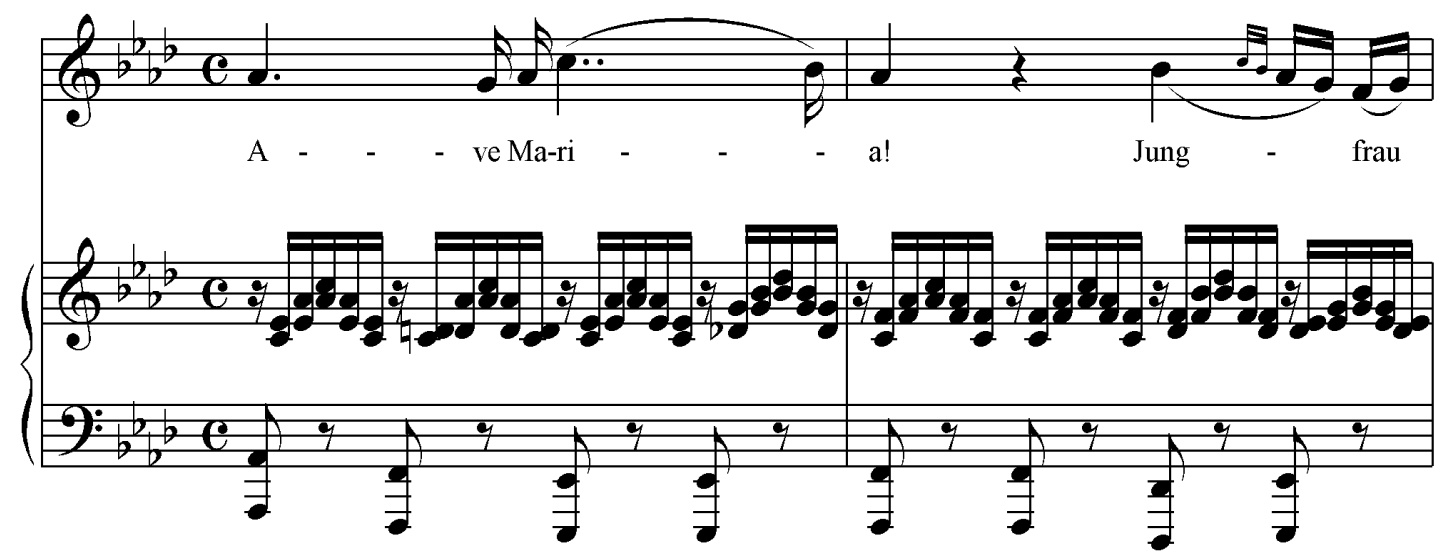

FRIEDLAENDER, M. (Ed.). Schubert: Lieder, vol. I. Frankfurt: C. F. Peters, ca. 1884, p. 206. 
EXEMPLO 137: C. DeBUSSY. En bateau (Petite Suite $n^{o}$ 1), c. 1-5

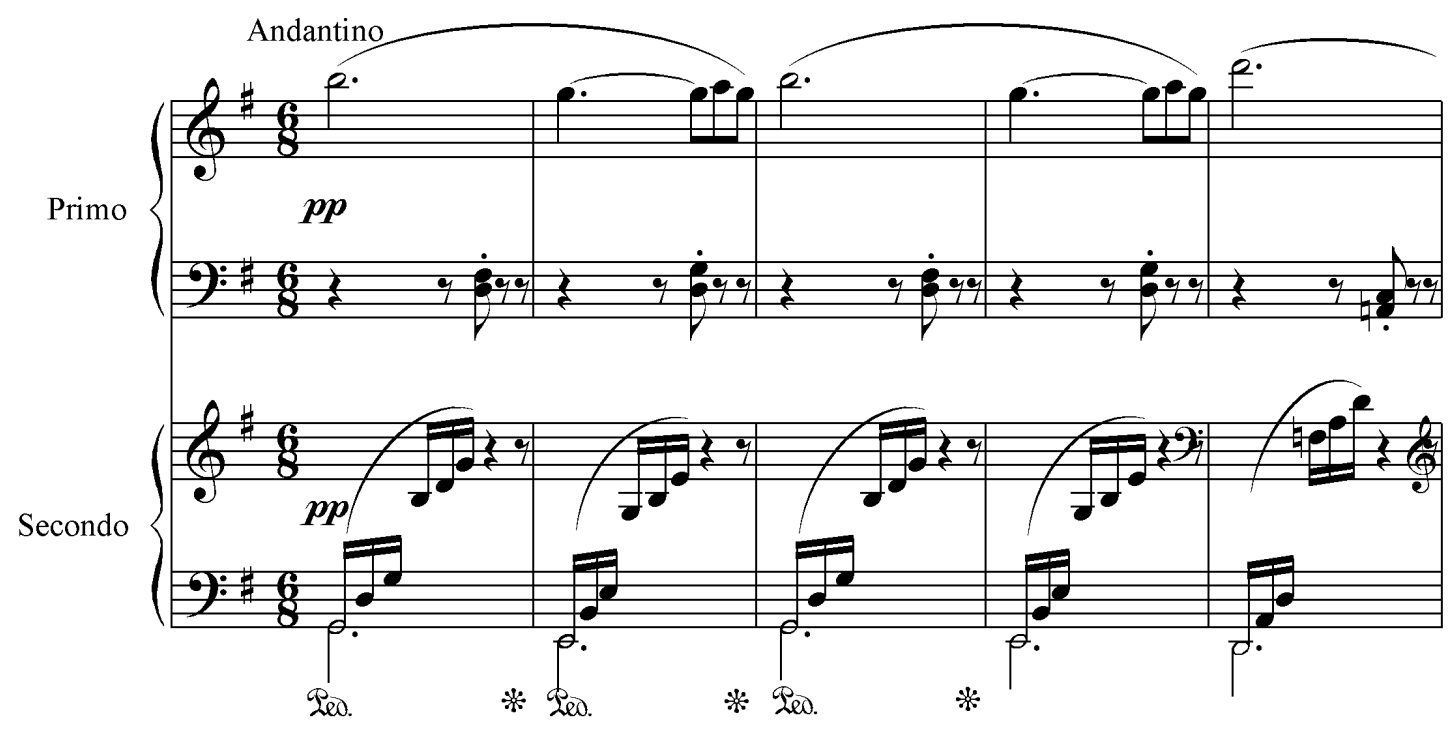

PHILIPP, I. (Ed.). C. Debussy: Petite Suite. Nova Iorque: International, 1954, p. 1.

$\mathrm{Na}$ melodia, Nepomuceno aplica os recursos de modalização da música popular brasileira descritos na entrevista reproduzida acima. Um momento é a cadência final gregoriano-nordestina da primeira frase (ver ex. 135 acima). No refrão, a parte da mão esquerda assume de maneira explícita o ritmo de habanera, e o elemento melódico modal, como no exemplo acima, é ainda mais nítido na utilização do mixolídio com sua quarta aumentada, ou, na terminologia de Nepomuceno, o sétimo modo gregoriano, onipresente na música nordestina:

EXEMPLO 138: A. NEPOMUCENO. A jangada, c. 25-28

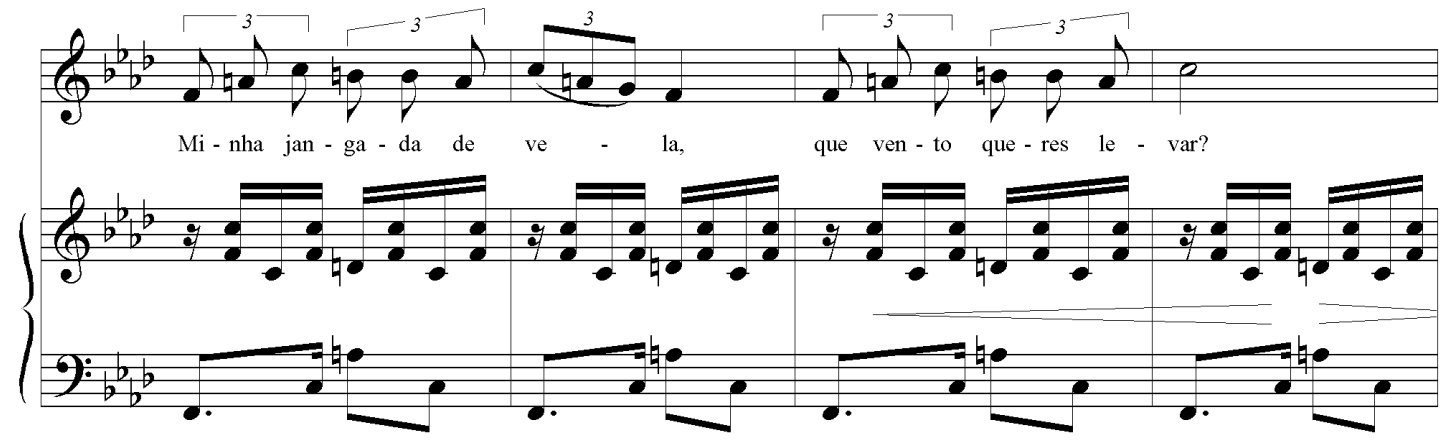

PIGNATARI, Dante (Ed.). Canções para voz e piano. São Paulo: EDUSP, 2004, p.274.

Dentro da extrema economia de meios que temos em A jangada, destaca-se o grau de sofisticação atingido pelo compositor em seu vocabulário expressivo. Um exemplo é a pulsação latejante do intervalo cromático, herança italiana que acompanha o lamento e que, 
com uma pequena variação, é aqui desenhada pelas notas superiores dos acordes da mão direita da parte do piano:

EXEMPLO 139: A. NEPOMUCENO. A jangada, c. 1-4

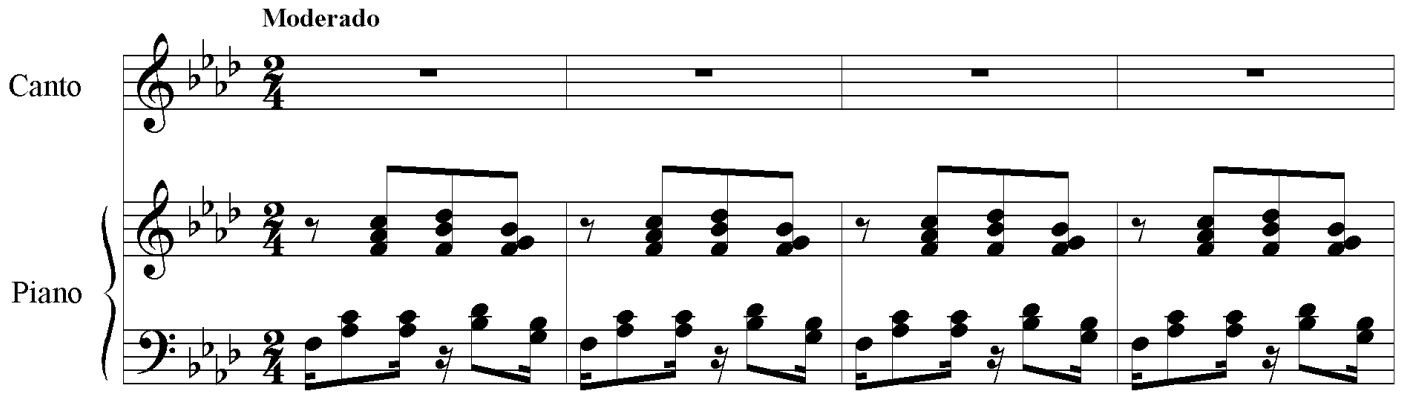

PIGNATARI, Dante (Ed.). Canções para voz e piano. São Paulo: EDUSP, 2004, p.273.

No segundo verso, o intervalo cromático se transforma em quartas, configurando uma representação quase gráfica do adejar das asas da garça mencionado na terceira estrofe do poema (Sobre as águas, como a garça, gosto de ver-te adejar):

EXEMPLO 140: A. NEPOMUCENO. A jangada, c. 13-17

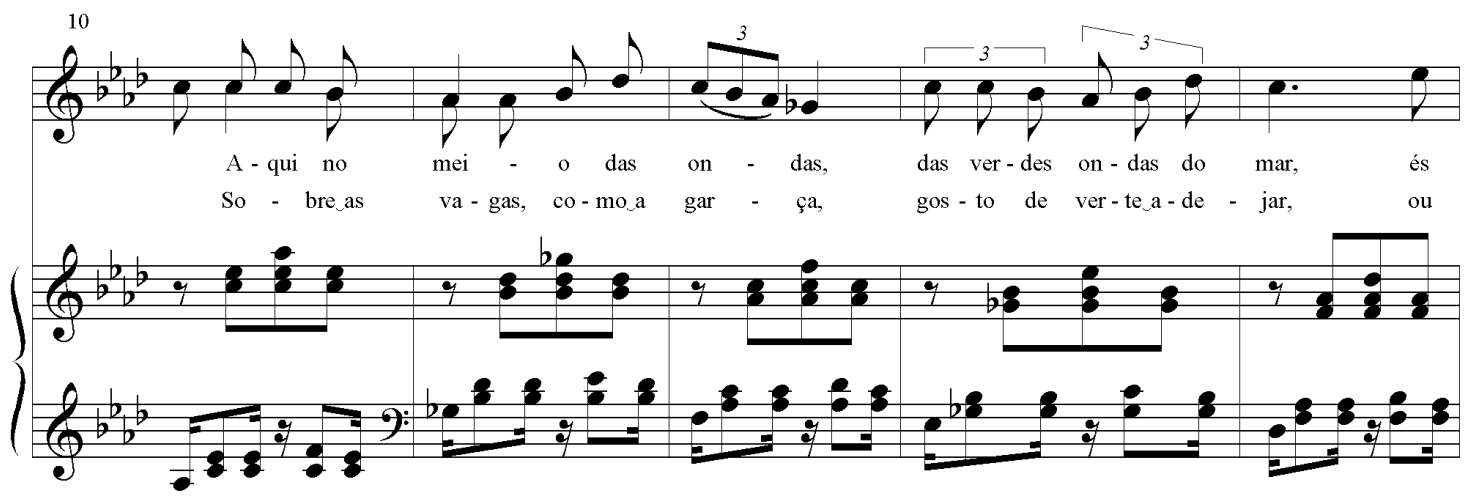

PIGNATARI, Dante (Ed.). Canções para voz e piano. São Paulo: EDUSP, 2004, p.273.

A concisão e a economia de meios, a riqueza de possibilidades interpretativas, tanto no contraponto rítmico do piano como na parte vocal, e ainda o equilíbrio na mistura de elementos folclóricos e eruditos fazem d'A jangada um marco na história da música brasileira. Nepomuceno une aqui recursos únicos a outros já incorporados ao seu estilo, como por exemplo, e especialmente, a complexidade do contraponto rítmico-melódico de um acompanhamento aparentemente simples que já tínhamos constatado em Medroso de Amor. Já o gregoriano embutido na música nordestina, que subliminarmente, não reconhecido como 
tal e passado pelo filtro francês já tenta se fazer presente em sua primeira canção, Ave Maria, aqui comparece explícito, com potência e originalidade. Com A Jangada, Nepomuceno cria com grande sutileza um modelo da síntese dos elementos populares e eruditos, europeus, africanos e indígenas que fundamenta toda a música brasileira. 


\section{CONSIDERAÇÕES FINAIS}

No artigo Entre o Erudito e o Popular (ver Referências), em uma linha de investigação que o levou a identificar uma representação das forças envolvidas na gênese da música brasileira em um conto de Machado de Assis (WISNIK, 2004, p. 15-105), José Miguel Wisnik discute a formação cultural do país através da união de elementos eruditos e populares no período que vai da Semana de Arte Moderna de 1922 à fundação de Brasília. É essa a síntese aclamada por Mário de Andrade na obra de Heitor Villa-Lobos e que foi por ele integrada no contexto do projeto estético e ideológico modernista.

Essa miscigenação já se vinha dando na música desde o século XIX, especialmente e de maneira mais notável, a princípio, nos gêneros semi-eruditos de salão que culminam nos tangos brasileiros de Ernesto Nazareth; com sua mistura improvável de lundu e Chopin, eles são emblemáticos nesse sentido. Essa receita, elaborada com os ingredientes da diversidade étnico-cultural que caracteriza nosso país e principal responsável pela grandeza e pelo êxito internacional da música brasileira no século 20, é encarnada, segundo Wisnik, pelo protagonista do conto de Machado e sua alma cindida entre o erudito e o popular:

\footnotetext{
À primeira leitura, "Um Homem Célebre" (Várias Histórias, 1896) expõe o suplício do músico popular que busca atingir a sublimidade da obra-prima clássica, e com ela a galeria dos imortais, mas que é traído por uma disposição interior incontrolável que o empurra implacavelmente na direção oposta. Pestana, célebre nos saraus, salões, bailes e ruas do Rio de Janeiro por suas composições irresistivelmente dançantes, esconde-se dos rumores à sua volta num quarto povoado de ícones da grande música européia, mergulha nas sonatas do classicismo vienense, prepara-se para o supremo salto criativo, e, quando dá por si, é o autor de mais uma inelutável e saltitante polca. (WISNIK, 2004, p. 17).
}

No gênero vocal de salão, temos a modinha, que une elementos populares ibéricos e recursos melódicos e vocais da ópera italiana. No âmbito erudito, o fenômeno se dá a princípio de maneira bastante imperfeita: a ópera $O$ Guarani, de Carlos Gomes, estreada em 1870 em Milão, junta um "assunto" brasileiro com música italiana. Dessa época temos ainda exemplos esporádicos de aproximação do universo popular: na música instrumental, um deles é A Sertaneja, de Brasílio Itiberê da Cunha, também de 1870, que envolve um tema popular célebre em uma moldura pianística lisztiana. 
Essa síntese de popular e erudito, de nacional e internacional que caracteriza a produção musical do Brasil, se dá pela primeira vez de maneira intencional e continuada nas canções em português de Alberto Nepomuceno. Ela já ocorre na primeira canção publicada pelo compositor em 1887, Ave Maria. Como vimos, temos nesta canção uma harmonia de notas acrescentadas que identificamos como sendo de origem francesa, uma determinada modalização da tonalidade que foi explorada especialmente por Fauré e que se relaciona diretamente com a prática do cantochão. Ora, os cânticos populares do Nordeste brasileiro, religiosos ou não, também apresentam traços marcantes de suas origens gregorianas, tendo-se contaminado em diferentes graus com práticas indígenas, negras e ibéricas. Nepomuceno certamente absorveu essa musicalidade na infância e na juventude, e a verte em sua música, de maneira instintiva talvez, a princípio, como na Ave Maria, e de maneira decididamente intencional no final da vida, como em A Jangada. Então, como atesta a entrevista reproduzida no capítulo anterior, nosso compositor já tinha feito coletas e análises da música tradicional nordestina. Na Ave Maria, temos por uma lado a musicalidade inerente aos versos em português e o balanço do compasso 6/4, que inevitavelmente nos lembram e remetem aos cânticos populares, e por outro, além da harmonia "francesa", a aproximação formal com o coral luterano.

O estilo de Nepomuceno se constitui através da incorporação e da mistura de ingredientes muito diversos oriundos da musicalidade da língua portuguesa falada e cantada no Brasil, da música folclórica tradicional, da música popular urbana e das práticas européias contemporâneas. De fato, são poucas e esparsas as canções que exibem de maneira explícita elementos rítmico-melódicos retirados da música popular: Medroso de amor, Xácara, Cantigas e A Jangada. Temos ainda o fado em Trovas I, o ritmo espanhol de Trovas II e a simplicidade rítmico-melódica de Canção do Rio. No resto do cancioneiro, esses elementos de origem diversa se distribuem de forma difusa.

Já a formação ideológica sob a influência da Escola do Recife levou Nepomuceno a estudar na Alemanha, caso único entre os compositores-bolsistas do século 19. De volta ao Brasil, ele tenta reproduzir domesticamente o fenômeno do lied, central no romantismo alemão, que é por sua vez um movimento essencialmente nacionalista. O nacionalismo de Nepomuceno tem sua origem na matriz romântica germânica. De lá ele trouxe também Wagner, influência importante no cancioneiro sobretudo pela contribuição para a criação de um recitativo caboclo. Ora dize-me a verdade é um bom exemplo. 
Além de criar uma música brasileira, o compositor cearense pretendeu inserir essa música na vanguarda de seu tempo. Essa vanguarda, para Nepomuceno, alinha-se à reação francesa ao cromatismo wagneriano, movimento que se inicia com Fauré e que tem em Debussy seu maior representante. Nepomuceno demonstra sua potência criativa nesse campo já em 1894, com as duas canções sobre texto de Maeterlinck. A partir daí, ele procede a um verdadeiro reprocessamento abrasileirante do lied romântico alemão ${ }^{28}$. A modernidade só é resgatada em 1915, com Luz e névoa e Canção da ausência, ambas sobre textos do simbolista Hermes Fontes. Essa vinculação entre a vanguarda e a estética simbolista devia estar profundamente entranhada em Nepomuceno, já que coincide com a identificação de Debussy com os poetas simbolistas, especialmente Paul Verlaine e Stephane Mallarmè.

O cancioneiro de Alberto Nepomuceno incorpora uma grande variedade de procedimentos e de elementos constituintes. É o caldeirão onde o compositor foi vertendo diversos ingredientes de procedência diversa: modinha, música ibérica, ópera italiana, recitativo wagneriano, música popular urbana e folclórica, romantismo alemão, vanguarda francesa e, acima de tudo, a língua portuguesa falada e cantada no Brasil, para dele fazer jorrar um dos mais importantes mananciais que vão irrigar a criação da canção brasileira nas primeiras décadas do século 20.

\footnotetext{
${ }^{28}$ No manuscrito inédito do ensaio sobre as 13 Canções de Amor de Camargo Guarnieri, de 1944 (em BARONGENO, 2007, p. 87), Mário de Andrade se refere a Nepomuceno e a Francisco Braga como "lideristas", ou seja, compositores de lieder, termo que ele aparentemente usa ao referir-se à canção erudita sem vínculo com o folclore.
} 


\section{REFERENCIAS}

ALMEIDA, Renato. Compêndio de História da Música Brasileira. $2^{\mathrm{a}}$ ed. Rio de Janeiro: F. Briguiet \& Cia., 1958.

ANDRADE, Mário de Aspectos da Música Brasileira. Belo Horizonte, Rio de Janeiro: Villa Rica, 1991.

ANDRADE, Mário de. Ensaio sobre a Música Brasileira. São Paulo: Martins, 1962.

ANDRADE, Mário de. (Ed.) Modinhas Imperiais. Prefácio. São Paulo: Martins, 1930.

ANDRADE, Mário de. Pequena História da Música. $4^{\mathrm{a}}$ ed. São Paulo: Martins, 1953.

AZEVEDO, Luiz Heitor Correa de. 150 Anos de Música no Brasil. Rio de Janeiro: José Olympio, 1956.

AZEVEDO, Luiz Heitor Correa. Música e Músicos do Brasil. Rio de Janeiro: Livraria-Editora da Casa do Estudante do Brasil, 1950.

BARONGENO, Luciana. O Espírito da Canção: ensaio de interpretação a partir da obra de Mário de Andrade. Dissertação (Mestrado em Artes) - Escola de Comunicações e Artes, USP, São Paulo, 2007.

BECKER, Heinz. Brahms, Johannes. In: SADIE, 1980, vol. 3, p. 155-190.

BERRY, Wallace. Structural Functions in Music. Nova Iorque: Dover, 1987.

BRINKMANN, Reinhold. Schumann und Eichendorff: Studien zum Liederkreis Opus 39. Munique: Musik-Konzepte, 1997.

CANISIUS, Claus. Goethe und die Musik. Munique: Piper, 1998.

COLI, Jorge. Música final. Campinas: UNICAMP, 1998.

CORRÊA, Sérgio Alvim. Alberto Nepomuceno: catálogo geral. $2^{\mathrm{a}}$ ed. Rio de Janeiro: FUNARTE, 1996.

DODERER, Gerhard. Modinhas Luso-brasileiras. Lisboa: Fundação Calouste Gulbenkian, 1984.

EINSTEIN, Alfred. Schubert: the man and his music. Londres: Granada, 1971.

FISCHER-DIESKAU, Dietrich. Robert Schumann: Das Vokalwerk. Kassel: Bärenreiter, 1985.

GLAUERT, Amanda. Hugo Wolf and the Wagnerian Inheritance. Cambridge, Reino Unido: Cambridge University Press, 1999. 
GREEN, Douglass M. Form in Tonal Music. $2^{\mathrm{a}}$ ed. Nova Iorque: Holt, Rinehart and Winston, 1979.

GRINDE, Nils. Grieg, Edvard. In: SADIE, 1980, vol. 7, p. 717.

HALL, James H. The Art Song. Oklahoma: University of Oklahoma Press, 1953.

HODEIR, André. Les Formes de la Musique. $7^{\mathrm{a}}$ ed. Vendôme: PUF, 1978.

ISAACS, Alan; MARTIN, Elizabeth. (organizadores): Dicionário de Música. Rio de Janeiro: Zahar Editores, 1985.

KRAMER, Lawrence. Music and Poetry: the nineteenth century and after. Berkeley: University of California Press, 1984.

KRAMER, Lawrence. Music as Cultural Practice. Berkeley: University of California Press, 1990.

RUE, Jan La. Guidelines for Style Analysis. Nova Iorque: W. W. Norton, 1970.

MACHADO, Cacá. O Enigma do Homem Célebre: ambição e vocação de Ernesto Nazareth. São Paulo: IMS, 2007.

MAMMÌ, Lorenzo; NESTROVSKI Arthur; TATIT, Luiz. Três canções de Tom Jobim. São Paulo: Cosac Naify, 2004.

MARIZ, Vasco. A Canção Brasileira. 5a ed. Rio de Janeiro: Nova Fronteira, 1985.

MAYER, Hans. Wagner. Hamburgo: Rowohlt, 1959.

MEIER, Barbara. Robert Schumann. Rowohlt, 1998.

MILCHMEYER, Johann Peter. The true Art of playing the Pianoforte. (Tradução crítica e introdução de Dante Pignatari). Trabalho apresentado como requisito parcial para a obtenção do título de Mestre em Artes. City University, Londres, 1992.

MOSER, Hans Joachim. Goethe und die Musik. Leipzig: C. F. Peters, 1949.

NECTOUX, Jean-Michel. Gabriel Fauré: a musical life. Cambridge, Reino Unido: Cambridge University Press, 1991.

NEPOMUCENO, Alberto. Canções para voz e piano (Ed. Dante Pignatari). São Paulo: EDUSP, 2004.

NICHOLS, Roger. Debussy. In: SADIE, 1980, vol. V, p. 307.

NOSKE, Fritz. French Song from Berlioz to Duparc. Nova Iorque: Dover, 1970.

NOSKE, Fritz; BENTON, Rita. Mélodie: the 19th century. In: SADIE, 1980. 
PEREIRA, Avelino Romero. Alberto Nepomuceno e a Canção Brasileira. In: NEPOMUCENO, Alberto. 15 Manuscritos para Canto. Rio de Janeiro: Funarj/EMVL/CPD, 2000, p. XVII-XXII.

PEREIRA, Avelino Romero. Música, Sociedade e Política: Alberto Nepomuceno e a república musical. Rio de Janeiro: Editora UFRJ, 2007.

PIGNATARI, Dante. Touch and Texture in Classic and Romantic Piano Music: aspects of an evolution. Dissertação (Mestrado em Artes) - City University, Londres, 1992.

PRATT, George. The Dynamics of Harmony. Filadélfia: Open University Press, 1984.

REICH, Nancy B. Clara Schumann: the artist and the woman. Londres: Victor Gollancz Ltd, 1985.

ROSEN, Charles. Romantic Poets, Critics, and Other Madmen. Cambridge, EUA: Harvard University Press, 1998.

ROSEN, Charles. The Romantic Generation. Cambridge, EUA: Harvard University Press, 1998.

SAMS, Eric. The romantic lied. In: SADIE, 1980.

SADIE, Stanley. (Editor). The New Grove Dictionary of Music and Musicians. Londres: Macmillan, 1980.

SCHOENBERG, Arnold. Structural Functions of Harmony. Nova Iorque: W. W. Norton, 1969.

SCHOENBERG, Arnold. Fundamentals of Musical Composition. Londres: Faber and Faber, 1970.

TATIT, Luiz. O cancionista: composição de canções no Brasil. São Paulo: EDUSP, 2002.

TOYE, Francis. Rossini: The Man and his Music. Nova Iorque: Dover, 1987.

TREVISAN, João Silvério. Ana em Veneza. São Paulo: Círculo do Livro, 1984.

VERMES, Viviana Mónica. Alberto Nepomuceno e a Criação de uma Música Brasileira: evidências em sua música para piano. Dissertação (Mestrado em Artes) - Instituto de Artes, UNESP, São Paulo, 1996.

WERBA, Erik. Hugo Wolf oder Der zornige Romantiker. Viena: Fritz Molden, 1971.

WISNIK, José Miguel. Entre o Erudito e o Popular. In: Revista de História 157, p. 55-72. São Paulo: EDUSP, 2007.

WISNIK, José Miguel. O Coro dos Contrários. São Paulo: Duas Cidades, 1977.

WISNIK, José Miguel. O Som e o Sentido. $2^{\mathrm{a}}$ ed. São Paulo: Companhia das Letras, 1999. 
WISNIK, José Miguel. Sem Receita. São Paulo: Publifolha, 2004.

YOUENS, Susan. Schubert: Die schöne Müllerin. Cambridge, Reino Unido: Cambridge University Press, 1992. 